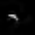




\section{UNIVERSITY}

OF FLORIDA

L I B R A R I E S

COLLEGE LIBRARY 



\section{UNIVERSITY}

OF FLORIDA

L I B R A R I E S

COLLEGE LIBRARY 



The Rise of Economic Individualism

.


Digitized by the Internet Archive in 2011 with funding from

LYRASIS Members and Sloan Foundation

http://www.archive.org/details/aspectsofriseofe00robe 


\title{
Aspects of the
}

Rise of Economic Individualism

$A$ Criticism of Max Weber and his School

\author{
BY \\ H. M. ROBERTSON, PH.D. \\ Senior Lecturer in Economics in the University of Cape Town, \\ formerly Fellow and Assistant Lecturer of the University of Leeds; and \\ Research Student of Emmanuel College, Cambridge
}

KELLEY \& MILLMAN, INC.

NEW YORK

1959 
DST PUBLISHED IN 1933 


\section{CONTENTS}

Preface

page vii

Editor's Preface ix

Introduction xi

Chapter I The Puritan Doctrine of the "Calling"

II Pre-Reformation Capitalism

III The Renaissance State

IV Calvinist Theocracy and Jesuit Casuistry

$\mathrm{V}$ Protestant Opinion on Usury

I I I

VI Catholic Opinion on Usury

(I) The influence of the Jesuits

133

(II) Summary of relations between Protestant and Catholic Teaching on Economic Affairs

VII The Influence of the Discoveries 
TO THE MEMORY OF MY FATHER 


\section{PREFACE}

This book is an attempt to provide a more realistic treatment thar has been found hitherto of a topic which has of late years been widely discussed. It is an attempt to use a historical instead of a sociological method to solve historical problems. It was first written in $1928-9$ as a dissertation for the degree of Doctor of Philosophy in the University of Cambridge, from material mostly collected during the tenure of a research studentship at Emmanuel College. It was written in such leisure time as I was able to afford while lecturing at the University of Leeds, and has now been revised and rewritten in leisure moments at Cape Town. Access to libraries has been a little difficult during the actual period of writing, and I am conscious that there are some gaps in my bibliography. I regret especially my non-access to certain German works and Continental periodicals. Despite this, I venture to claim that my essay does make some new contributions to the literature of the subject.

My indebtedness in matters of detail is acknowledged in the appropriate footnotes. But I should like here to acknowledge some major indebtednesses and thank those who have played a leading part in my work. To Dr Maud Sellers, who gave me my early training, I owe whatever merit I may possess as an economic historian. I have gained much from contact with my supervisor of studies, Mr F. R. Salter, with my tutor, Mr E. Welbourne, with Dr G. G. Coulton, with Professor R. H. Tawney, with Professor J. H. Jones and with Principal J. F. Rees. Dr H. F. Stewart very kindly lent me a rare book of Jesuit casuistry: I am also tempted to add the names of the late Professor Unwin and of Professor Henri Pirenne, whose influence on my historical outlook has been so great that I cannot regard it in an impersonal light.

I regret that the work of Ernst Beins, Die Wirtschaftsethik der calvinistischen Kirche der Niederlande, 1565-1650, appeared 
too late for me to be able to make use of it. I should like to draw attention to some of Dr Beins' conclusions. Readers of my book will realise the importance of what Dr Beins has to say of the doctrine of the "calling" in the Dutch Church-that it was to be regarded as an opportunity more for exercising love of one's neighbour than for gain; that unremitting toil was condemned as leaving no time or energy for the service of God, while the exercise of the desire for gain was the mark of the foolhardy who trusted in riches instead of the providence of God. The support given by the Dutch Church to state-authorised monopolies, particularly the East and West India Companies, should be noted, and also the demonstration that the economic thought of the Dutch Church was not specifically Calvinist, but was that common to all countries and creeds in the seventeenth century. Dr Beins concludes that we can assess the economic ethic of the Dutch Calvinist Church "only as a very rudimentary ethic of capitalism". I may add that Professor E. A. Johnson's recent American Economic Thought in the Seventeenth $C$ entury also provides no support for the view that the spirit of capitalism was a product of the ethic of the Protestant churches. While mentioning recent literature on the subject I should like to point out that the best guide to further reading is provided in an article by Dr P. J. Bouman on "Eenige beschouwingen over de historische betrekkingen tusschen godsdienst en kapitalisme" in De Economist, March I932, pp. I $8 \mathrm{I}$ ff.

I must thank a number of friends in Cape Town-Professor Leslie, Professor Walker, Mr J. G. van der Horst, Mr Arthur Sewell-for their kindness in reading my manuscript either in whole or in part, while many improvements are due to Professor Clapham's patient criticism, and his aid both in preparing my manuscript for the press and in correcting proofs. Professor Farrington checked a number of my translations from the Latin.

Cape Town

H. M. ROBERTSON

November 1932 


\section{EUROPEAN ECONOMIC DEVELOPMENTS IN THE 16th CENTURY}

By H. M. ROBERTSON

\section{THE PROBLEM}

When I was asked to give a talk to this seminar ${ }^{1}$ upon Economic Developments in the 16th Century, I was set one of the most difficult tasks of my teaching career. In the ordinary lecture courses for which I am responsible, at least thirty-five lectures are devoted to the 16 th century. Even so, my conscience occasionally priclss me over some of the simplifications of the material and of the issues which I necessarily have to introduce. To expect me to cover such an imposing topic with even moderate success or satisfaction within a single lecture period is a sheer impossibility.

In casting round for a starting point, I find the problem becoming more and more intractable. One cannot deal with economic developments in isolation. How can one leave out the politics of the 16th century, particularly when it was precisely in this century that national rivalries begot, on the economic side, those significant lines of thought and axioms of policy which have become known as "Mercantilism"? How can one leave out military affairs, when, quite apart from any direct economic significance of particular campaigns, the problem of maintaining mercenary armies, equipped with armaments more expensive both in first cost and in use than any hitherto developed, was the constant financial problem of the age? It must be remembered that, during the 16th century, the years when Europe was completely at peace were less than a quarter of the total.

How can one leave out the Reformation? Quite apart from any theoretical and highly speculative argument about the influence of religion upon the "spirit of capitalism", there is the important economic fact that, in some countries, the Church had been a great property owner, and the Reformation brought about significant alterations in the distribution of wealth. Also worthy of consideration is the effect on the papal taxation system, with its wide ramifications of international banking, which in any case ran counter to current nationalistic tendencies. There is the undeniable fact that the 16th century's wonder-city, Antwerp, owed part of its development to the immigration of Iberian Jews, occasioned by religious persecution, and lost its prosperity with startling suddenness as the result of essentially religious quarrels. How can the economic historian of 16th century France or Germany neglect their religious civil wars?

1) Paper resd to the Untversity of Cape Town Benlor Beminar, 18th May, 1949. 
The economic historian cannut even claim that art is irrelevant, more particularly if architecture is included, for it was a century of considerable investment in building. Yet even painting or tapestry-work might be of commercial importance, while the chronology of the great schools of painting suggests that a commercial and an artistic blossoming may well stand towards each other in a relation of cause and effect. The intellectual activity of the renaissance is equally an indispensable factor for the economic historian to bear in mind, whether one considers the wider sphere of the increase of knowledge and its varied new applications, or the narrower commercial one, bound up with the simple fact that the main process of the spread of knowledge depended upon and provided the markets for the new industries of printing and papermaking.

Closely linked up with this is another aspect which the economic historian can hardly afford to neglect-the history of technical accomplishments which resulted in the rise of new industries, in the transformation of production methods in old ones, and in their localization in new areas. Amongst these significant technical developments we must not lose sight of the rapid evolution of business techniques, in bookkeeping, in finance and in general business organization. It was largely in the 16 th century that the evolution took place whereby the crude Genoese experiments of the mid-14th century gave way to joint stock undertaks ings, which proved the Voorcompagnieen of the great East Indian ventures that marked the opening years of the 17 th century, and set the example on which so much of our present economic organization is based. Again, the pool and the cartel are not (as is too often supposed) jevelopments of the 19th century. As Professor Strieder insisted, "in the 16th century, cartels were a frequent phenomenon of Western European economic life". It was in the 16th century-the century from Luca Paciolo to Simon Stevin-that systematic double-entry bookkeeping introduced into business practice not only its own direct accounting benefits, but alsn the objective distinction between the "firm" as such, and the partners who were merely its owners and (or) directors.

The difficulty of fitting the 16 th century into a single hour is not lessened by the further consideration that it was in this century that the expansion of the Western European economy into the other continents took place. Adam Smith was writing as an economic historian when he said that "the discovery of America, and that of a passage to the East Indies by the Cape of Good Hope, are the two greatest and most important events recorded in the history of mankind".

A final difficulty is that the 16 th century itself cannot be treated in isolation. It was economically a period of rapid change, a period of innovation, of enterprise and of investment, which followed a long period of relative stagnation. One cannot give an adequate picture of the 16 th century's economic trends simply by going forward from the year 1500 . It may often be necessary to pick up the threads as far back as the early or mid-14th century, which was in many ways (and not only on account of the Black Death) a watershed in medieval economic life. 
II

\section{POPULATION MOVEMENTS}

Nearly a quarter of my time has gone already, and I have so far merely rehearsed my problems and difficulties, and made excuses. It is high time to attempt something positive, such as at least considering: those items which would be regarded as essential to any contemporary socio-economic survey.

At once we meet a new difficulty: there are no trustworthy generalized demographic facts available for the 16th century, and not even very much in the way of informed speculation. So far as can be judged, however, in most countries of Europe the pre-Black Death population figures had been little more than re-established at the beginning of the 16 th century; and in the most populous country of all, France, they were still far from having been restored. The total population of Western Europe was less than that of the curtailed Germany of 1946, and was nut much greater (if any) than that of present-day France, with Belgium and the Netherlands added. Most of it was in the South and West (France and Italy, followed at a distance by Spain and Portugal) ; while the former Burgundian lands were relatively populous and the northern countries and eastern Europe were sparsely peopled. Yet, though France was the most populous single country, her inhabitants were far outnumbered by the total population of the lands comprised within the Habsburg dynastic groups.

In the course of the 16th century, a sensible increase in the European population occurred, possibly. as much as 20 per cent. The increase was not universal. France seems actually to have lost population during the Wars of Religion. Spain, on the other hand, would seem to have nearly doubled hers, despite expulsions, adding over four millions in a hundred years. However, though southern Europe retained its primacy, a shift, neither pronounced nor constant, appeared to have set in towards the Channel-Lower Rhine areas. A population movement which had perhaps even greater significance was the resumption of a rapid movement of urbanization. It was from the 16th century, when a total of thirteen or fourteen European cities attained a population of 100,000 or more, that Werner Sombart dated the significance, for economic development, of the mass demands of the great cities.

\section{III}

\section{OCCUPATIONS OF THE PEOPLE AND METHODS OF ORGANIZATION: INDUSTRY}

The growth of the big cities necessarily brought about profound alterations in the ways in which men lived and earned their living together. I suppose the most characteristic feature of the typical medieval small town was its craft gilds. The gilds had found their justification in the existence of a community of interest between the mastercraftsmen, the young men learning the trade and the consumer. It was regarded as 
being in the consumer's interest to have a professional body which would control the processes of manufacture and permit the sale only of goods which reached a minimum standard of workmanship. It was regarded as being both in his interest and in that of the learner that entry to the craft should be by way of apprenticeship, which guaranteed a technical and moral education; and no less in the interests of the masters of the craft. It was looked on as being to the consumers' interest that the gild should be there to fix reasonable prices, as well as to the craftsman's interest that he should be protected from the "unfair competition" of the colleague who worked and lived harder and cut prices and profits, or who even cut costs by developing newer, simpler, more effective methods of production.

The reasonableness of these assumptions would seem to have been bound up with a comparatively undeveloped mechanical technique and with the existence of a comparatively small and closely-knit urban population. By the fourteenth century it was already all too clear that the craft gilds of cities which specialized in production for outside markets -in the cloth manufactures of the Italian or Flemish cities, for examplecould not perform these functions of providing a mutually satisfactory compromise between all interests. By the sixteenth century, it had become exceptional for gilds anywhere to be representative of more than a privileged minority even within the gild structure. Despite this, the gilds persisted - often in altered form, like the London Livery Companies -and frequently added to their powers during this century.

One consequence was a great development of the "putting-out" system of industry. When this spread, like the "New Drapery" of the Low Countries, into the rural districts, it acted, to some extent, as a check upon urbanization. (It must be admitted, however, that the example just given does not admit of statistical demonstration, seeing that Antwerp grew from a town of 4,500 houses to one of 13,000 houses in the century preceding the "Spanish Fury" of 1576.) In considering rur?l industry and the putting-out system, it is as well to bear in mind that the combination was by no means confined to the obvious case of textiles. It was also, for example, typical of the small metallurgical industries which were grouped in the rural districts where the ores were found, where the forests were extensive enough to provide plenty of charcoal, and where the forges and tilt-hammers could be sufficiently dispersed on the banks of the streams which afforded water-power.

\section{IV}

\section{AGRICULTURE}

Though the peasantry might engage in industrial by-employments, the main activity of rural Europe was still agriculture. Yet changes, political, commercial, financial, military and even religicus, were in the 16th century putting the finishing touches to a transformation which was breaking up the essential uniformity of Western European agrarian arrangements. 
The military and administrative inadequacies of the feudal nobility had naturally reduced their importance in the new national states, and even their landlords' functions suffered as a result. Moreover, the re-adjustments which had had to be made to meet the new conditions created by the great catastrophes of the 14th century had mostly been to the disadvantage of landlords. The Black Death had raised the value of labour relative to that of land, and thus had made it almost impossible for the cultivation of the lords' demesnes to be conducted at a profit, either on the old basis of servile labour (when the serfs knew that the lords were powerless to force them to continue with their predial tasks of compulsory agricultural labour), or even on the basis of wage labour. For the overhead expenses of demesne farming were heavy, and wages were high relatively both to the prices of agricultural produce and to the money rents received in commutation for labour services which could no longer be exacted.

By the beginning of the 16th century, all this had already played havoc with the traditional ordering of manorial agriculture. In Italy, it had frequently led to the supersession of the original landlords by townsmen, and to the supplanting of serfdom by mezzadria, or shares-farming. In France, the same system had also grown up (though without the disappearance of the seigneurs) under the name of métayage; but just as frequently, perhaps, French developments had tended towards the creation of a rent-paying, lease-holding small peasantry. In the Netherlands and even more in England, in addition to the emergence of rent-paying smallbolders, there had also been a much greater tendency towards large-scale leasehold tenant-farming, when the desmesne as a whole had been let out to the former hofmeier or bailiff.

The 16th century did not alter this situation radically. During the course of the century, however, a sharp yet persistent rise in prices occurred-a matter to which reference must be made later-and this affected the relations between the lucky rent-paying peasant and the unlucky rent-receiving landlord. To a greater or less exter $t$, throughout Western Europe, there was a supplanting of the older landlords, who felt constrained to sell their patrimony piecemeal, when they were unable to live merely on the annual income it provided, by new landlords drawn from the towns. But some of the landlords fought back to retrieve their position-in parts of Germany, where central government was weak, by claiming privileges which could be turned to their profit, not as landlords, but as local territorial rulers; in England, rather more effectively, by getting rid of tenants paying low rents, and enclosing whole tracts of land for wool-farming. In both cases this led to great agrarian unrest; in Southern Germany to the butchery which ended the hapless Peasants' War of 1524-1525.

The expanding wool-market, which provided an inducement towards changing the organizational methods and objectives of agricultural production in England, played a similar part in Spain. The merino sheep, carefully developed by the Moors, provided one of Spain's most important export articles. Thus the sheepbreeders (who also enjoyed the advantage 
of belonging to a privileged aristocracy, still privileged on account of their part in the reconquest of Moorish Spain by the Christian forces, which was only completed about 1492) were able not merely to oppose the enclosure for tillage of land recovered from the Muslims, but, in the 16 th century, to secure the reversion to waste of large tracts of cultivated land. The soil was then, however, subjected to all the wasteful usages which so often accompany extensive sheep-farming, especially on the seasonally migratory pattern-such as excessive veld-burning, deforestation, overstocking, and consequent soil-erosion aggravated by the formation of gulleys or "dongas" out of the sheep-paths. It would, indeed, appear to have been something of a tragedy for Spain to have had available so easily and so short-sightedly exploitable a resource.

In Eastern Europe another branch of trade in agricultural commodities, the Baltic corn trade, also seems to have led to significant deviations from the general trends of western European agrarian development. During the period of active colonization from the West, the eastern peasant-who had to be attracted by the greater advantages he could enjoy-had not been a serf. But he lacked local markets for his produce; and he was at a great disadvantage in comparison with the large producer in the bulk supply of grain to distant markets. One consequence was that serfdom of a more and more extreme type was successfully introduced into eastern Germany, Scandinavia and the Baltic lands, just as it was disappearing from Western Europe. It spread east into Russia in the latter part of the reign of Ivan the Terrible, just about the time when, in England, the last vestiges of servile status were either being abolished or falling into complete disuse, in the reign of Elizabeth. By strengthening the hands of the "Junkers", the victory of the nobles in the South German Peasants' War of 1524-25 had, in all probability, more lasting social effects in Prussia or Pomerania than in Alsace and the Palatinate.

The general tendency is for trade to act as an emancipatory force where authoritarian controls are concerned. In the 15 th and 16 th centuries, however, the Baltic grain trade contributed to a wide spread of serfdom in Eastern Europe, just as in later centuries the transatlantic sugar, tobacco or cotton trade contributed to the spread of negro slavery in the Caribbean islands and the Americas.

\section{V}

\section{MINING}

During the 16th century Europe's mineral production reached one of its periodical high-water marks. This was partly the result of technical developments in mining, such as the discovery, about 1450, of an improved process for separating silver from copper ores, which led, by 1530 , to a five-fold increase in Europe's annual silver production. It was partly the result of metallurgical developments, which stimulated a definite trend towards larger scale production in the metal industries; and partly the result of an increased mineral demand for armaments, for shipbuilding and for industrial equipment. The greatest expansion of mining took 
place in the Central European mountain regions from the Harz to the Carpathians. A statement in an Imperial Decree of 1525 that the value of the annual mineral production of the Empire was more than 2 million gulden, and that mining and smelting provided a living for 100,0no people, is one of the few statistical estimates of medieval or early modern times that present-day researchers classify as probably under-estimates.

The development of mining had particular significance because it was so closely bound up with royal finance. A large contribution to the Habsburg revenues was secured from rights of pre-emption over the ores produced, the rights being leased out to business houses, or combinations of business houses, which also had to finance the actual production, transport and smelting of the ores and marketing of the metal. It was largely in this way that the fortunes of the great Fugger family were amassed, which were in turn so unstintingly placed at the disposal of the Habsburgs (for their mutual profit) that Jakob Fugger and Rich dir? not hesitate to remind Charles V, after he had bribed his way through the electoral contest of 1519, "it is well-known that your Imperial Majesty could not have gained the Roman Crown without my aid".

\section{VI}

\section{THE DISCOVERIES}

Before the middle of the century, the mines of Central Europe were no longer such an effective prop to Hapsburg finance. But this was compensated for, and, indeed, in large part caused by a great new influx of silver from America.

The last decade of the 15th century saw both the Spanish discovery of the New World and the Portuguese discovery of the sea-route to the East. It was the latter discovery which, at first, had the most noteworthy effect upon Europe's economy, though in the long run their relative importance was, perhaps, different. The sea-route to the Indies provided a means by which the spices of the East, its silks, muslins and calicoes (and later its tea and porcelain) reached European markets in increasing quantities and at lower transport costs. We find it difficult, nowadays, to imagine the importance of spices in the 16th century, even though this is the factor which is responsible for our presence in a University at Cape Town to-day. Yet, when sugar was all but unknown, when neither refrigeration nor winter stock-feed was available to provide anything but spiced or salted meat in winter, when there were few vegetables to add vitamins and variety to the diet, and when spices or other Eastern drugs formed the main materia medica, they held a really important place in Europe's commerce.

The benefits of the new route for spices were shared, somewhat unequally, perhaps, between consumers and traders. The consumers had their requirements supplied more fully than before, at somewhat lower prices, while the traders put into their pockets the bulk of the savings in transport costs or in the profits of Levantine intermediaries. The 
accumulation of capital in their hands was in this way greatly fostered. Actually, the real cost of spices to Europe was still further diminished by the discovery of America. Gold, and particularly silver, were found there in abundance; and this cheaply-won silver was an ideal means of acquiring those spices which could hardly be paid for in heavy woollen cloths, wines or herrings, such as were the staple commodities of the European export trades. Thus the eastern and western voyages of discovery proved complementary. Overseas trade, shipping, shipbuilding and contributory branches of industry or agriculture-e.g. cultivation of hemp for ropes, or flax for sails-naturally flourished, and, in flourishing, contributed to a further expansion of all branches of the European economy.

The Portuguese kings proved as anxious as any other monarchs to make the most of their special opportunities. They regularly entered into marketing arrangements for sharing the profit to be derived from a spice monopoly with groups of merchants who would malse substantial cash advances. One result was to concentrate the European spice trade on Antwerp, chosen as a convenient distribution centre, and this contributed to the port's lusty growth.

By no means all the American silver went into the Eastern spice trade, of course. Vast quantities poured into Spain, and had, for some time, a stimulating effect upon the Spanish economy-for the expansion of which a new-found national unity was another favourable factor. American silver also flowed out into the other countries of Europe; and the greatly increased amounts of money in circulation diminished its value. That is to say, prices of commodities rose, and as money supplies continued to increase, prices continued to rise. Trade and industry (which were activated in any case by the appearance of new objects if demand in the form of American commodities, and by the greater ease of importing eastern wares) found a continuous stimulus in this steady rise. Merchants and manufacturers could count on an inflation of their profits from the automatic increase in the money values of their stocks, and from the tendency for costs to rise more slowly than sale prices. This profit inflation caused a redistribution of wealth in favour of the entreprencur groups, a more rapid accumulation of capital and an increased tempo of innovation, which (largely through the "multiplier" effect of increased investment upon the further production of income) appears to have been an important factor in the rapid economic progress that characterised the sixteenth century.

\section{VII}

\section{THE DARKER SIDE}

This rapid progress had its darker side. I am not thinking of such obvious abuses of freedom of enterprise as led Philip II's government in the Netherlands to restrict life assurance business, which at times was actually leading to murder! Nor am I even thinking, in the first place, 
of all the ambitious speculations which failed and involved both investors and innocent creditors in serious losses, of the attempts at monopolistic corners which did not come off, or of the vicious circles which sent so much good money after bad in unproductive loans to impecunious rulers. Yet it is worth recalling that perhaps the most interesting section or Ehrenberg's book on the Age of the Fuggers was the section headed "The Period of the Financial Crises"; and I cannot think of any big business house of the 16 th century which retained its eminence into the 17 th century.

One aspect of the really dark side I have already mentioned-the further spread of serfdom in Eastern Europe. Another was the disappointment, in many parts of the continent, of much of the 16th century's early promise.

For Venice, perhaps, the century never showed promise; seeing that when it began the city's privileged trade position in the Levant had been undermined by Turkish conquests, and that it was also not long before the presence of the Portguese athwart the traditional spice routes cut off one of the more important elements of her commerce. But the policy. which Venice adopted in the circumstances was one which could only have diverted more trade to less exacting rivals.

The ebullient economy of Upper Germany had depended largely on its Venetian comnexions. Augsburg, Nuremberg and neighbouring cities were distributing centres for eastern wares imported through Venice; manufacturing centres of fustians or cloth made with cotton or wool imported through Venice, and banking centres just as closely linked with Venice. The market for the mineral production, not merely of the Tirol but of Central Europe as far east as Hungary, was Venice.

The German merchants were adaptable enough to make the adjustments necessary to re-orientate their trade upon Antwerp. But their losses in the wave of bankruptcies which followed the financial crisis of 1559 , followed by the sudden collapse of Antwerp's trade from the early years of the Eighty Years' War, undermined this resilience, particularly because Central European mining, which had been the mainstay of development, was already in full decay. For this was one industry which the American discoveries did not stimulate: not merely was European silver-mining as such adversely affected, but, as the by-product, silver, had always covered a considerable part of the costs of extracting lead or copper, these branches also found it difficult to pay their way.

So a part of Europe, which had seemed destined for brilliant development, sank back into relative poverty. Although the miners themselves had never been well rewarded, there was now an inevitable deterioration in living conditions. It is not without significance that the dwarfs of German folk-tale are usually mountain dwellers and miners, so common was a stunted growth amongst them; just as it is significant of living conditions in the forest industries for many centuries that, in the traditional nursery stories, it usually seemed to be woodcutters and chareoalburners who were forced by poverty to abandon their children. 
This, incidentally, leads to consideration of a further aspect of the darker side of things. The "price revolution" of the 16th century led to a decline in real wages, by reducing the purchasing power of money wages. It is true that this afforded business men ar expansion of their investment opportunities, and thus widened employment horizons and facilitated technological innovations which increased productivity-yet it must be stressed that it involved an initial decline in standards of living, which might be severe. Moreover, an economic expansion of this nature might be chccked in either of two ways; either by the action of inflation itself in so reducing purchasing power as to shrink the market for consumption goods, or by the shortage of labour induced by monetary inflation raising real wages again, and rendering the business men's investment unprofitable. There is evidence of both these checks having come into operation in different parts of the European economy in the 16 th century.

The Venetian and German economies were not alone in undergoing a shrinkage in the course of the century. The brilliant economic recovery of France after the Hundred Years' War, about which Bodin could still boast as late as 1568, was hardly more than a memory when the Edict of Nantes, in 1598, ended more than thirty-five years of increasingly bitter civil war, aggravated by an inflation which got out of hand. The long period of closure of the Schelde by the Dutch after 1585 ended Antwerp's career as an international port; while there were already ominous signs by the end of the century that the Spanish economy was unable to meet the strain of all its apparent good fortune. And here there seems to be a tragedy within a tragedy, and a puzzle which I have never found satisfactorily explained. By what process of decay were the Moors, whose industrial civilization was still brilliant even as late as the Conquest of Granada, reduced to the pitifully inert refugees of 1609 , who showed not a sign of economic revival in their exile?

\section{VIII}

\section{THE ROOTS OF MERCANTILISM}

The last section of my all too rapid survey leads to one or two general reflexions which may help in the interpretation of some further 16th century trends, this time in economic thought and economic policy.

All change necessitates adjustments on the part of those whose activities have to be adapted from the old to the new conditions. This necessity is often inconvenient, and often it involves direct economic loss to individuals or to groups. How, indeed, does a change in economic structure and organization come about, save through the stimulus of the stick behind as well as of the carrot in front? The mechanism of change requires the negative diversion of resources, human and material, away from those employments where they can no longer be so profitably employed, as well as the positive diversion of resources into those employments which have become more profitable. 
In the 19th century there was, perhaps, a tendency to minimise or even to neglect the costs of economic progress; at present there is, perhaps, a tendency to pay them an exaggerated respect. In the 16th century these costs were so much to the fore as to make it appear almost axiomatic that one man's or one country's gain was another's loss; that greater activity here meant less employment there; that, as the Dutch proverb succinctly puts it, De cen man zijn brood is de ander zijn dood.

Parallel, therefore, with the great economic changes of the 16th century, and on account of them, we must discern the other important thread of resistance to change. Accompanying debasement and inflation of money supplies went attempts to keep prices stable by decree. The effort which went into the development of new branches of foreign trade was matched only by the effort which went into the restriction of such commerce to privileged corporations in the interests of "an ordered trade". If serfdom had completely disappeared in Elizabethan England, one section of the celebrated act, which was placed on the Statute Book in 1563, provided that men might "be compelled to be reteyned to serve in husbandrye by the yere". Specific measures were taken, in many countries, against most of the more obvious innovations in the economy.

Particularly where economic conditions took an unfavourable turn, the use of the state as a protective agency for existing but threatened interests became common practice. As a result of this, in Germany, where there were so many independent authorities, shrinking markcts were still further shrunk, and there was a considerable reversion to what was nothing more than the familiar pattern of urban monopoly. As Von Below has reminded us, "it is, perhaps, good to remember that in the 16th century, as compared with the Middle Ages, the number of gilds still increased; the compilation of their statutes grew more detailed, and gild regulations were in general more precisely defined than ever before . . ."

In France, also, the powers of the gilds had been considerabiy strengthened by the end of the century, through the ordinances of 1581 and 1597. As regards foreign trade, population, employment and monetary policy, a protectionist resolution of the Third Estate in 1576 already gave a fairly succinct formulation of what was to become the mercantilist diagnosis and the mercantilist panacea:

"As the strength of this Kingdom ... consists in the multitude of inhabitants and in the money which they can secure from neighbouring countries .... and as there is no better means of feeding and maintaining a plentiful population of good and excellent workmen, and by this means to draw money from abroad, than by employing them to work up stuffs and merchandize in the Kingdom ... May it please Your Majesty to order that henceforth no goods may be exported from this Kingdom that have not been manufactured into a finished product there; and contrariwise that it shall not be permitted ... to bring in ... any manufactured goods under penalty of confiscation." 
But to pursue these thoughts significantly would involve passing on from the 16th century to the century of Mun and Colbert.

\section{IX}

\section{MERCANTILISM AND CHRISTIAN OPINION ${ }^{2}$}

Although I have already taken up all my allotted time, I know that I owe my invitation to address you to-day to a belief that I would talk about something different. The course of the discussion has made it clear that you are interested in what I called "theoretical and highly speculative argument about the influence of religion upon the "spirit of capitalism'." Consideration of this topic can quite naturally follow the last section of my address, in which I dealt with the development of policy and ideas. Since your patience does not seem to be completely exhausted, I shall try to make some slight amends by doing a little overtime and completing my talk with a discussion of this controversial problem in the interpretation of the economic trends of the sixteenth century.

Even so, you will probably be disappointed, for I think it must have been sheer literary incompetence which has given the author of Aspects of the Rise of Economic Individualism something of a reputation for fire-eating-the same sort of literary incompetence as would appear to have allowed the book to be all things to all critics.

There is no doubt that the economic ideas and ideals of the 16th century, as well as the social conditions of that century were very different from those we associate with the Middle Ages. It is tempting to relate all these changes to changes in religious belief, particularly as more spectacular economic progress has been made in modern times in Protestant than in Catholic countries. All the same it is very misleading. There are many other factors of greater importance.

To start with, it is worth noting that the economic teaching of the medieval Church reflected current ideas upon economic questions rather than having itself moulded these ideas upon a basis of Christian doctrine. A coherent body of economic thought was not to be derived directly from Christ's own teaching. The biblical content of medieval economic doctrine was drawn from scattered texts, which had necessarily been interpreted in accordance with current notions derived from observation and experience of the contemporary scene. As conditions changed, the attitude of the Church was also modified. Even if the Reformation had never occurred, the teachings of the Church would have been profoundly affected by the transformation of the gild system, the decline of manorial agriculture, the expansion of trade and the development of finance which characterised the end of the Middle Ages.

2) The remainder of this address formed an addendum which was given by request after discussfon of the preceding parts in ths Seminar. 
It is possible, moreover, that the influence of the medieval Church is overrated. In the Middle Ages, churchmen had almost a monopoly of self-expression. We have little record of what the layman thought; but his acts, we know, were often at variance with what he was taught in Church. There is no doubt that the emancipation of secular thought during the Renaissance led to a reaction against medieval economic teaching. Nothing could have been further opposed then Mercantilism to medieval notions of distributive justice secured through a policy of sale at the "just price". The ideals of Mercantilism were to gain national wealth by the expedient of impoverishing neighbour countries; to buy as cheaply and sell as dearly as possible in international trade; to keep wages as low as possible so as to reduce labour costs and undercut competitors in export markets. Yet Mercantilism was adopted in Catholic as well as in Protestant lands; and it was, in fact, merely an extension of the external economic policy which had grown up in the autonomous towns of the Middle Ages. The new monarchs of the Renaissance, Catholics as well as Protestants, Popes as well as secular rulers, themselves called into being or protected monopolies and cartels such as were condemned by canon law, and made a dead letter of prohibitions of usury: Yet, where secular emancipation did not take place, even though clergy of the Reformed religion might be in control instead of Roman Catholic priests, the old social ideals were maintained intact. If I might slip into the 17 th century for a moment, I would stress that nowhere was there a more intense control of the economic life of the individual in the interest of the old canons of social justice than in the American Puritan colonies of New England.

None the less, it is often regarded as axiomatic nowadays that Calvinism emerged as the religion which encouraged the strivings of the business man. In its cruder forms this doctrine asserts that Calvinisn glorified acquisitive zeal, or, at the least, that it encouraged a belief that success in business might be regarded as a sign of being numbered amongst God's elect. Such a perversion of Calvinism is not unthinkable, though it is worth noting, not only that it would have been a perversion, but that it would have been a perversion particularly repulsive to strict Calvinists, as involving the sinful presumption of attempting to uncover the inscrutable workings of Providence. A more likely popular perversion of Calvinism would have been of quite a different nature. This would have been to let one's belief in Predestination lapse into fatalism, and lead to lethargy and lack of interest in one's work through a sense of the powerlessness of individual efforts in the face of The Lord's will. Some years ago the Commissioners appointed by the Carnegie Corporation to enquire into the "Poor White" problem in South Africa seriously debated whether one factor causing a lack of gumption and of self-reliance amongst "Poor Whites" was not this type of fatalism bred by a "wrong: Calvinism". This forms an interesting commentary on the widely accepted belief in Calvinism as a stimulant to business enterprise. It suggests, very strongly indeed, that influences other than doctrinal ones determine the Calvinist's reaction to economic opportunities and stimuli.

In its subtler forms, the doctrine of the Calvinist origins of "the spirit of capitalism" does not attempt to suggest that Calvinism directly 
stimulated the desire for business success; but asserts that the strong sense of "calling" derived from Luther's and from Calvin's teaching created a sort of worldly asceticism which created the bourgeois business virtues of concentration and industry, of time-saving and punctuality, of thrift and of scrupulous honesty in the fulfilment of contracts. In this way, it is alleged, the business ethics and institutions which underly the structure of "modern capitalism" were created by the Calvinist churches.

Once again, however, a glimpse at South African society is sufficient to throw doubt on the efficacy of Calvinism in prornoting these particular bourgeois virtues. What is still more to the point, however, is that Adam Smith. that wise observer of men and institutions, had more than a century and a half ago shown that these particular economic virtues were the product of social and economic conditions. In his day, he wrote, "We are more industrious than our forefathers... Our ancestors were idle for want of sufficient encouragement to indistry ..." And surely any observant South African, considering some of the effects of our customary "Colour Bars" upon the African population, would confirm how much idleness proceeds from want of sufficient encouragement to industry. As a matter of fact, Calvinist Scotland, in 1776, was not yet remarkable for the industry of her inhabitants. The common people of Scotland, said Adam Smith, "neither work so well, nor look so well" as the English, because they did not live so well. "Where wages are high ... we shall always find the workmen more active, diligent and expeditious, than where they are low; in England, for example, than in Scotland; in the neighbourhood of great towns, than in remote country places". It was the development of industry and commerce that promoted habits of diligence; not Calvinistically inspired habits of diligence that promoted industry and commerce.

Parsimony, according to Adam Smith, was encouraged by the growth of opportunities for the investment of capital saved by thrift. On the other hand, prodigal hospitality, only just dying out in the Highlands of Scotland, "seems to be common in all nations to whom commerce and manufactures are little known". Different habits of business honesty, again, might be explained by the nature and intensity of business dealings normally transacted. Even before the publication of the Wealth of Nations, in his lectures to his students, Adam Smith had pointed out that:

"Wherever commerce is introduced into any country probity and punctuality always accompany it. These virtues in a rude and barbarous country are almost unknown. Of all the nations in Europe, the Dutch, the most commercial, are the most faithful to their word. The English are more so than the Scotch, but much inferior to the Dutch, and in the remote parts of this country they are far less so than in the commercial parts of it. This is not at all to be imputed to naticnal character, as some pretend; there is no natural reason why an Englishman or a Scotchman should not be as punctual in performing agrcements as a Dutchman. It is far more reducible to self-interest .. ," 
I think that in these passages Adam Smith gave a sound commonsense explanation of the influence of commerce itself upon commercial habits. To come closer home once more, it is quite plain that it was selfinterest (i.e., painfully learnt experience) and not a Calvinistic conscience which taught South African farmers not to include stones or scrap iron or other heavy objects amongst their wool!

\section{APOLOGIA PRO LIBRO MEO}

Even if Adam Smith's explanation is too simple, the mere fact that it can be plausibly advanced is a criticism of the theory which I am now discussing. May I be briefly autobiographical to amplify this statement?

I first entered my study of Max Weber's essay on "The Protestant Ethic and the Spirit of Capitalism" confidently expecting to find there a full justification for what appeared to be generally accepted as a plain statement of fact and as an explanation of the main lines of post-Reformation economic development and economic doctrine. Cunningham, Ashley, Lipson, Tawney all seemed to accept this position. Though. of the two writers who had at the time the greatest attraction for me, Pirenne was critical and Unwin had not-at any rate in his published workexpres.sed an opinion, Unwin's disciple, Ashton, whose cautious and factr $x$ l writing I also greatly admired, had indicated that he shared the majority view.

When I came to read Weber, however, I was not convinced. I found that, though he made appeals to history, he had not written an historical study, nor, indeed, had he claimed to have done so. He had been following another method, in which he created a conceptual instrument of study, an "ideal type" of Puritan entrepreneur imbued with a "worlaly asceticism", a religiously inspired sense of "calling" and a goodly array of bourgeois virtues. What is more, Weber had drawn his definitions so carefully that all attributes extraneous to this "ideal type" were rigorously excluded.

My first objection, then, was not against the construction of the "type" as such, but against the incautious use of such a type for more than its legitimate purpose, which ought to have been limited to clarifying the ideas of writers and readers who constantly reminded themselves that they were dealing only with a construction of their own minds. It seemed to me that Weber sometimes forgot this, and that his followers more frequently forgot it, and confused an ideal type with reality.

Evidently I did not make this point clearly enough. Quite recently, however, when rummaging through some old papers, I came across part 
of my original typescript, at a passage which I had deleted beiore publication, and I feel it might clcar away some confusion if I quoted it now:

"The survey of strictly limited fields is the basis of Max Weber's method. It shall not be mine. There can bc no cause for complaint if I follow the implications of Weber's theory onto fields which he ignores, and examine their truth. Criticisms directed against points which Weber neglects are as valid as those directed against the narrow position he has so strongly invested. Direct criticism and direct attack will not be lacking. But it will, be supplemented by criticisms and suggestions made as the result of envisaging the problem of the rise of the capitalistic spirit or of economic individualism from other angles. Avenues over which Weber did not travel will be explored, or their existence will be indicated and the direction in which they appear to lead will be suggested . . ."

It was a little brash, perhaps; and the conclusion was a piece of youthful cheek which probably led to the deletion of the passage. I had continued, ". . and Weber's footnotes will not be allowed to head me off".

In view of what I think must be a fairly general misunderstanding of my work, I rather regret that I merely deleted this and one or two oth $\rightarrow$ r passages, instead of explaining my position fully in better chosen words. That I did not meet Weber exactly on his own ground was not due to a misunderstanding of what this ground was. It was because I could not accept the validity of his "ideal type" when that ideal type took on flesh and blood, and was used as an explanation of historical developments which its own careful limiting definitions precluded it from doing.

Unfortunately, in developing an alternative theme, I tried to kill two birds with one stone and so (if ever a mixture of metaphors is appropriate, it is here) I evidently again fell between two stools. My reading had convinced me that what I said a short time ago was correct, namely, that, even if the Reformation had not occurred, the traditional economic doctrine of the Catholic Church must have been greatly modified in order to be of guidance in altered conditions-first, by a change of emphasis, and eventually by the evolution of new elements of doctrine to cover situations not envisaged in the Middle Ages. This I tried to demonstrate by reference chiefly to the development of a more complex theory of interest (which was largely undertaken by the Jesuit order, whose special mission was involved, and which supplemented the simple prohibition of usury to the point of superseding it).

This I tried to combine with another line of argument. To discount the practical importance of Weber's worldly-ascetic Puritan "ideal-type", I tried (by choosing different criteria) to put up a different "ideal type", who might be regarded as equally representative of a "spirit of capitalism". This alternative was the worldly-wise Jesuit "ideal-type"-but it was of the essence of the argument that the type should be plausible, but obviously specious. I was not trying to argue that the Jesuits, instead of the Calvinists, were responsible for developing a "spirit of capitalism"; 


\section{ERRATUM}

(March, 1950 issue)

Page 52, line 2 to be deleted, and the following line inserted:

"conclusion on the basis of an argument from an 'ideal type' which cuuig."

Perhaps this was a foolhardy procedure, especially as I did not sufficiently eliminate the anti-Jesuit flavour from the Jansenist literature which proved such a handy guide to the construction of my lay-figurc. Thus I allowed myself, for instance, to use an unnecessary disparaging phrase of Cardinal de Lugo, although I was quoting a piece of his economic reasoning with which I was fully in accord. Yet, after all, I think the construction of the Robertsonian "ideal-type" has proved as successful as the Weberschem. Its aim was plausibility combined with speciousness; and it was so plausible as to cause a learned and angry book to be written to prove that it was specious!

Had I wished to mingle in controversy, my powers as a controversialist would have been dulled by the fact that there was so much in Father Brodrick's Economic Morals of the Jesuits with which I agreed. In particular, I would have agreed with his frequent plea that "the economic situation of the period has to be taken into account". For that, I thought, was the main substance of my own message on this point; and my fundamental disagreement with Father Brodrick could only be on his interpretation of my book and of its purpose. Once that is correctly perceived, I should like to claim Father Brodrick not as my controvertor, but as my supporter.

There is, of course, one complication. I think one must recognise a substratum of truth in the idea that both Calvinism and Catholicism contributed to that methodizing of life on which Weber laid such stress. But I am convinced that it has been given altogether exaggerated significance.

Was it worth your while to wait while I tagged this appendix onto my remarks? Perhaps it was, if only to learn why I would not make it more than an appendix. I am sure it was for me, because, though I have avoided the controversy of reply and rejoinder, which seemed more likely to generate heat than light, it is a relief to get this much off my chest. I need hardly say that it has all along been something of a blow to my self-esteem to find that even eminent critics believed my purpose was to show that wicked Jesuits rather than innocent Calvinists were to blame for the excesses of a selfish capitalism-and that they sometimes believed other, inconsistent, things as well, and at the same time. How it warmed my heart when, on a brief visit to London not so very long ago, Professor Robbins sat down beside me at lunch one day and talked, not of my book on Capitalism, or on Calvinism, or on Weber, but of my book on Economic Individualism! For to me, the rest of the book had always been something which I felt I had to get out of the way before that subject, so much nearer to my heart, could be tackled without the distraction of emotional overtones. 
The omission from my paper to this Seminar of any discussion of the controversy in which I had myself once taken part was, therefore, deliberate. Distrustful as I am of the use of any single formula as an explanation of complex historical events, I cannot feel that the particular formula of a capitalistic spirit having been moulded or fortified by the Puritan ethos is either necessary or helpful to the understanding of the economic developments of the 16th century. The important probleins seem to lie elsewhere.

Cape Town. 


\section{INTRODUCTION}

\section{MAX WEBER'S SIGNIFICANCE}

Max Weber is responsible for the opinion, widely held to-day, that Protestantism, especially in its Puritan form, has had a very great influence in forming the "spirit of capitalism", and, therefore, in forming capitalism itself. In 1904-5 he published two articles under the title of "Die protestantischeEthik und der Geist der Kapitalismus" in which this thesis was maintained. They not only inaugurated a whole literature, they gave a new direction to the whole of modern thought on a fundamental problem of economic history. I claim that they directed it on to the wrong lines.

It is not hard to understand why these theories should have been adopted so widely. They are the type of generalisation that would obviously have a popular appeal; and they can be made to form a convenient and serviceable weapon in religious controversy. They have been accepted in many cases because of their utility to the propagandist. Many writers have taken advantage of an unpopularity of capitalism in the twentieth century to employ them in attacks on Calvinism, or on other branches of religion. But the theories have also been accepted in other and less likely quarters.

It is remarkable that historians should have been so ready to accept the arguments of this piece of dialectic. For the reasoning employed is not that of the historian. Despite a wealth of references, its foundations have not been laid on a sound historical analysis. A philosophy of historical development which has been fashioned in the "constructional"I method of the sociologist might have been expected to have met with more opposition.

I "Constructional" because it constructs abstract ideal types instead of accurately describing facts. 
Weber attempted to establish a reverse chain of causation from that advanced by Marx in the economic interpretation of history. He sought a psychological determination of economic events. In particular he saw the rise of "capitalism" as the result of the rise of a "capitalist spirit". What was this capitalist spirit?

To Weber it was hardly more than bilaterál. It consisted first in a rationalist as opposed to a traditionalist outlook. It consisted also in the desire to seek profit continuously (by means of the rational organisation of free labour) for its own sake-even as a duty - and not for the purpose of enjoying the fruits. It cannot be denied that the ideal capitalist mentality is rational, if the spirit of capitalism is to mean anything more than that of acquisitiveness. It is probable, also, that Calvinism, created by a man whose favourite idea was considering "things in themselves, not words", 1 has led to the expansion of a rational methodising of life. It may be admitted at once that to this extent Calvinism has been favourable to the growth of a spirit of capitalism. But Weber's second criterion of the capitalist spirit is too narrow. It leads inevitably to the defect which I feel vitiates his whole argument; he hardly considers any capitalist other than the Puritan capitalist who seeks wealth for the fulfilment of his "calling".

This added refinement is quite superfluous. A realist like Marx, who originated the discussions on capitalism, would no doubt have been greatly astonished if he had been asked to consider only those whose money-making activities were promoted by religious or quasi-religious ends to be possessed of the true capitalistic spirit. This is what we are asked to do. The great renaissance financier, Jakob Fugger, a good Catholic, was urged by his nephew, Georg Thurzo, to retire from business on account of the involved state of the family affairs. He rebuked his nephew for his faint-heartedness and said that he "had quite another disposition, he would make money as long as he could". This is disregarded as an expression of the capitalistic spirit, as ${ }^{I}$ A phrase often employed by Calvin. 
it had no ethical tinge. ${ }^{\mathrm{I}}$ Yet it was an example of precisely the type of "worldly asceticism", making earning an end in itself, which is put forward as the great contribution of the Calvinists and the Puritan sects to the rise of the spirit of capitalism. ${ }^{2}$

To most people to-day the typical "capitalist" is a purely secular creature who, far from regarding his daily occupation as a religious calling, sees no reason for religion to meddle with business affairs at all. He was the same in previous ages. Perhaps he resented the claims of religion to act as a moral witness in the affairs of everyday life, like the merchant Gromelgayner in Dr Wilson's Discourse of Usury:

Merchants doings must not thus be overthwarted by preachers and others, that can not skill of their dealings. And thys over great curiositie of some to meddle in other mens matter, I muste tel you plaine, it is even the verie right waye to undoe al in the ende. ${ }^{2}$

Or perhaps he behaved like the typical capitalist whom Milton described in Areopagitica:

A wealthy man addicted to his pleasure and to his profits, finds Religion to be a traffic so entangled, and of so many piddling accounts, that of all mysteries he cannot skill to keep a stock going upon that trade. What should he do? fain would he have the name to be religious, fain would he bear up with his neighbours in that. What does he therefore, but resolves to give over toiling, and to find himself out some Factor, to whose care and credit he may commit

I Max Weber, "Die protestantische Ethik und der Geist des Kapitalismus", in Gesammelte Aufsaetze zur Religionssoziologie, I, p. 33 (Engl. trans. by Talcott Parsons, The Protestant Ethic and the Spirit of Capitalism, p. 51).

2 Yet Defoe, a good Nonconformist and the author of much sound economic moralising, gave a chapter of his Complete English Tradesman (II, ch. xli, in the edition of ${ }^{7738)}$ to retiring from business, in which he protested: "And indeed what temptation but that of mere Avarice, can lie in the way of a man possess'd but of $20,000 l$. to run into new adventures? What can he propose to himself better than what he already has?" (p. 206).

${ }^{2}$ Thomas Wilson, Discourse of Usury (1572), ed. Tawney, p. 250. 
the whole managing of his religious affairs; some Divine of note and estimation that must be. To him he adheres, resigns the whole Warehouse of his Religion, with all the Locks and Keys into his custody; and indeed makes the very person of that man his Religion; esteems his associating with him a sufficient evidence and commendatory of his own Piety. So that a man may say his Religion is now no more within himself, but is become a dividual moveable, and goes and comes near him, according as the good man frequents the house. He entertains him, gives him gifts, feasts him, lodges him; his Religion comes home at night, prays, is liberally supt, and sumptuously laid tc sleepe; rises, is saluted, and after the malmsey or some well-spic't bruage, and better breakfasted, than He whose morning appetite would have gladly fed on green figs between Bethany and Jerusalem; his Religion walks abroad at eight, and leaves his kind entertainer in the shop trading all day without his religion.

Nothing could be further from the Puritan than either of these two types. In neither case was the conception of the "calling" of any influence; in neither case did it stir the merchant to activity. Neither fits in with a Puritan setting. The second, indeed, would be much more at home among the Jesuits with their system of expert casuistry. Yet Milton described him as a typical possessor of the commercial spirit-a man who was not interested in religion, but was in business. And Wilson's Gromelgayner was intended to be the typical merchant of 1569 .

A quite unnecessary element has, then, been introduced into the definition of the capitalist spirit. Men do not need to be "called" to riches to devote themselves whole-heartedly to their pursuit without stopping to enjoy them. When King Pippin asked Alcuin, "Of what have men never enough?", he received the reply, "Of gain". I If men have the appetite for riches without a "call", they require no "calling" to organise a continuous striving after them.

I Lujo Brentano, Die Anfaenge des modernen Kapitalismus, p. I I5. 
The survey of the capitalist spirit inaugurated by Max Weber has also been unduly limited by a definition which excludes "Jewish pariah-capitalism" as something entirely alien to the real, respectable "bourgeois-capitalism". I This narrowness of definition, which dismisses every manifestation of the speculative or entrepreneur spirit from consideration, seems hardly suitable as a method of approach to the understanding of that frequently very eclectic person, the capitalist.

I do not, however, propose to press this line of criticism very far. To do so would involve me in a wider discussion of the growth of capitalism and the capitalist mentality than I am prepared to undertake. Though I criticise the theories connecting Protestantism with capitalism on account of the narrowness of their scope, I cannot do more than indicate alternative ways of approach to the subject of the rise of the spirit of capitalism. In the main, my criticisms will touch these theories on their own grounds.

My criticism must concern itself very largely with Max Weber's celebrated essay on "Die protestantische Ethik und der Geist des Kapitalismus". It is a topic which he made peculiarly his own; and as I am concerned with the repercussions of his theories I must often refer to their origin. I hope to show that owing to Weber's adoption of a sociological, and not a historical, approach to the subject, his main argument, which deals with the Puritan doctrine of the "calling", cannot be sustained. I hope to show also that secondary considerations make it impossible to accept the argumes: that the capitalist spirit is a product of the Protestant Ethic. I hope briefly to indicate, therefore, another approach to the problem of the rise of the "spirit of capitalism", ${ }^{2}$ which takes into account factors which religious sociologists have ignored, and gives a truer explanation 27I).

I Weber, loc. cit. pp. 8, n., I8I and n. 2 (Engl. trans., pp. 165-6, I86,

"Instead of "spirit of capitalism" I shall often use "economic individualism". They are not co-terminous; but the latter expresses more exactly one of the most important elements of the former. 
of the formation of the psychological elements in the historical development of economic forms, which I believe have been rightly (though over-) emphasised, but wrongly explained. I wish to show that the spirit of capitalism has arisen rather from the material conditions of civilisation than from some religious impulse. 


\section{Chapter I}

\section{THE PURITAN DOCTRINE OF THE "CALLING"}

According to Weber, the influence of Protestantism was not merely negative, in permitting the exercise of practices forbidden by the Catholic Church, but also positive, turning religion to capitalistic ends. The chief instrument of this he considered to be the doctrine of the "calling" which came in with Luther and introduced the ideal of an asceticism incumbent upon the laity as well as the religious; an asceticism not of the cloister, but practised in the affairs of everyday life, by the utter sacrifice of any self-indulgence, by unremitting industry in one's "calling", which was thus promoted to the quality of a religious exercise. He asserted, moreover, that on the Calvinists taking over this doctrine they made success in one's "calling" an outward and visible sign of the acquisition of spiritual grace. ${ }^{\mathrm{T}}$

$\mathrm{He}$ employed philological arguments to bring out the

I A collection of quotations might easily be made which seem to prove this, just as it is easy to collect quotations from before the days when one's worldly employment and position came to be known as one's "calling", which suggest that there was a common notion that worldly prosperity was sent by God to his elect according to their deserts. Thus one might quote the fourteenth-century moralist Gower:

"Dixerat ista deus, si que preceperit ipse

Quis seruare velit, prospera reddet ei

Campos frugiferos, botris vinetaque plena,

Temperiem Solis et pluuialis aque...."

(Vox Clamantis, II, v.)

"Cum bona siue mala sit nobis sors tribuenda

Ex propriis meritis, hiis magis hiisque minus...."

(Ibid. III, Prologue.)

It may be as well, therefore, not to lay too much stress on a presumed Calvinist belief that worldly prosperity is a sign that God has blessed one's "calling" and numbers one amongst his elect. 
importance of the doctrine of the "calling". He pointed out that there are no equivalents in the Romance (and Catholic) languages to the Protestant-German Beruf, the Protestant-Dutch beroep, the Protestant-English "calling", in the sense of "a lifetask", "a definite field in which to work". " He contended that Luther's reformation introduced both the word and the concept.

Luther is said to have written Beruf quite gratuitously in two places in his translation of Ecclesiasticus where the Septuagint gave in the one case ergon and in the other ponos, and where the Vulgate gave opus and locus.

This contention was strongly denied by Brentano, who pointed out that the Vulgate has not merely work but work of the calling (or thy commissions) - "et in opere mandatorum tuorum veterasce". He also asserted that "calling" or Beruf had its exact equivalent in the Latin of the Vulgate version of the passages of I Corinthians vii, 20-24, from which the Puritan use of the word "calling" was derived.

Unusquisque in qua vocatione vocatus, in ea permaneat. Servus vocatus es? non sit tibi curae; sed et si potes fieri liber, magis utere....

Unusquisque in quo vocatus est, fratres, in hoc permaneat apud Deum. ${ }^{2}$

There seems to be little doubt that Brentano's criticisms have value. It is not proved that Luther introduced both word and concept. It is true that the Vulgate versions do not express the modern conception of the "calling". But, on the other hand, it is also true that the early Protestant conceptions of the

I Weber, loc. cit. pp. 63 ff. (Engl. trans. pp. 79 ff., 204 ff.). I have adopted the phrase employed in Dr Talcott Parsons' translation for the original "Lebensstellung, umgrentzes Arbeitsgebiet".

${ }_{2}$ "Let every man abide in the same calling wherein he was called. Art thou called being a servant? care not for it: but if thou mayest be made free, use it rather.... Brethren, let every man wherein he is called, therein abide with God." See Brentano, Die Anfaenge des modernen Kapitalismus, pp. $136 \mathrm{ff}$. 
"calling" were different from those of the present day and nearer those of the Vulgate. ${ }^{x}$

There is one noteworthy feature of Weber's philological argument. Apart from this discussion of Luther's Berufskonzeption, Weber has made practically no use of Lutheran Protestantism in advancing his views, as he found himself unable to trace the spirit of capitalism in Lutheranism, but only in Calvinism, and among the Baptists and some Puritan sects. But Genevan Calvinism shared the use of a Romance tongue with French Catholicism, and therefore there is no contrast between Catholic and Calvinist phraseology.

To destroy the philological argument it is only necessary to quote the Calvinist version of the passage in Ecclesiasticus:

Demeure en ton rang et $t$ 'exercise en celui, et veille en faisant ton office. Ne t'émerveille point des cuvres du meschant; fie toi au Seigneur, et continue en ton labeur.

Here we find office taking the place of Beruf, and are reminded that it very often did so. The French office, the Spanish oficio, the Italian officio all of them bring to mind a similar identification of the worldly and the religious (for instance the French office means both "employment" and "worship") and are frequently used by Catholics in a way not radically different from the Protestant-English use of "calling" or German use of Beruf. ${ }^{2}$

I See below, pp. 6 ff. Cf. E. Troeltsch, The Social Teaching of the Christian Churches (Engl. trans. by Olive Wyon), pp. 120 ff., 610.

${ }^{2}$ As an example of this we might compare two pieces of secular writing, which would show clearly how the ideas suggested by the words were popularly understood. Two passages, from Shakespeare and Cervantes, will serve admirably. The English example is Falstaff's saying (I Henry IV, Act I, Scene ii):

"Prince Henry. I see a good amendment of life in thee; from praying to purse-taking.

"Falstaff. Why, Hal, 'tis my vocation, Hal; 'tis no sin for a man to labour in his vocation."

Compare this with the answer of the Sevillian thief to Cortadillo's 
Weber's case for asserting, on philological grounds, that Luther had introduced a novel conception of the "calling", bringing with it a new ideal of worldly asceticism, is not established. It seems on other grounds to have been an unnecessary innovation. The doctrine of Work has at any rate as old a history in the Christian mores as St Paul's-“we commanded you, that if any would not work, neither should he eat". Medieval Catholicism had recognised that the deadly sin of Accidia must be combated with work as well as watchfulness. This recognition had taken form in the Augustinian and Benedictine rules, the foundations of all monastic disciplines. The asceticism of which an essential element was a divinely ordained worldly toil was not, then, foreign to medieval Catholicism. And Luther had been an Augustinian monk. ${ }^{\mathrm{X}}$

But, it is argued, this asceticism was in the Middle Ages confined to the cloister. It had no part in the lives of any of the laity. To say that is to ignore the part which the friars were sent out to play-to take religion from the cloister into everyday life. It is to ignore the motives which led to the foundation of third orders. (It is not sufficient excuse for ignoring them to say that it was not considered to be as meritorious to be a member of a third order as to be a full religious; Calvinists do remark that he had never before heard of thieving by the grace of God (Novelas Ejemplares; Rinconete y Cortadillo, Clasicos Castellanos, xxvir, p. I67):

"- - Señor, yo no me meto en tologías; lo que sé es que cada uno en su oficio puede alabar á Dios..." (Sir, I am not up in theology, save that everyone can glorify God in his occupation).

Despite Weber's assertion that the "calling" had no Romance and Catholic equivalent, I submit that these passages are almost exact parallels. There can be no doubt as to the similarity of the ideas which they express.

${ }^{I}$ Brentano, Die Anfaenge des modernen Kapitalismus, pp. $134 \mathrm{ff}$. Dr H. F. Stewart, Dean of Trinity College, warns me that Luther's study of Augustine did not begin till some time after he had ceased to be a monk. It is still very probable, however, that his belief in the dignity of labour (not very strongly emphasised at first) developed with his study of St Augustine. 
not consider the butcher's "calling", even if the butcher is an elder of the Kirk, to be as honourable as the minister's. I) The Franciscan Order of Penitents, as befitted an order founded in the thirteenth century, was in some ways very similar to a religious gild. But it was more than this. It called for an asceticism exercised in the world not in the cloister, and it cultivated some of the bourgeois virtues-the same virtues which Weber stressed so much when he indicated the importance of Benjamin Franklin's worldly creed, his insistence that time is money and not to be wasted, his love of detail and exact reckoning. ${ }^{2}$ To the members of the Franciscan third order extravagance was forbidden; also, as with the Puritans, wasting one's time at feasts or masques or dances. It was recognised that the Brethren and Sisters of Penitence had worldly matters to which they had to attend. They had, for instance, to go to Mass during the Lent of St Martin and the Greater Lent "nisi personarum vel rerum incommoditas immineret"-their worldly duties had, in some measure, precedence over their duties of church attendance, which might perhaps have proved to be a greater concession to the commercial spirit than was allowed to the Puritans. Yet nobody has thought of pointing to Franciscan Puritanism as a breeding ground for the spirit of capitalism. Weber has indeed confessed that the preaching of the friars, and especially of the Franciscans, had anticipated very markedly the teaching of the Baptists (a sect in which he affirms the encouragement of capitalism through worldly asceticism was very strong) in attempts to impose an ascetic rule on the laity. But this, he said, can be accounted for first by the fact that all asceticism based on Biblical commands would tend to be similar, and secondly by the general tendency to reach the same results in all systems of mortifying the flesh. 3 This is probably

I Catholics recognised that a layman might reach a higher degree of perfection than a monk. Cf. Troeltsch, The Social Teaching of the Christian Churches, p. 243.

2 See below, pp. I6r ff.

3 Weber, loc. cit. p. 15 I, n. I (Engl. trans. p. 254). 
very true; yet the fact remains that if the teaching of the Baptists and of the friars was so similar one should only guardedly employ the teaching of the Baptists as a means of proving that the spirit of capitalism was a product of the Protestant sects.

The great objection to all the arguments based on the Puritan doctrine of the "calling" is, however, that it has not always had the content so constantly ascribed to it. Even if Weber is correct in his interpretation of the doctrine in its eighteenth-century manifestations, he is incorrect in projecting this back into the sixteenth century, when the doctrine wore an entirely different aspect.

At the beginning it was nothing but a new expression of the old belief in the existence of divine and natural distributive justice, a belief that different men were "called" to their several occupations and estates by a divine providence-as a result of which it was flouting providence to exhibit capitalistic enterprise ! ${ }^{\mathrm{I}}$

There seems to be no essential difference between the doctrine of the Catholics and the Puritans on this point. St Thomas Aquinas' teaching on distributive justice was that:

This... division of men in different occupations occurs in the first place through divine providence, which distributes the condition of men in such a way.... and also in the second place from natural causes, as a result of which it happens that there are different aptitudes for different occupations amongst different men. ${ }^{2}$

Despite the assertion that Aquinas has set his conception on an entirely different plane from the Puritans' by the stress laid

I This belief has survived in the still popular eighteenth-century hymn:

"The rich man in his castle,

The poor man at his gate,

God made them high and lowly,

And ordered their estate."

2 "Haec...diversificatio hominum in diversis officiis contingit primo ex divina providentia, quae ita hominum status distribuit. .. secundo etiam ex causis naturalibus, ex quibus contingit quod in diversis hominibus sunt diversae inclinationes ad diversa officia." 
upon natural causes in determining the choice of an occupation, ${ }^{\mathrm{I}}$ this seems to contain much the same idea as the doctrine of the "calling" in the sixteenth and seventeenth centuries. The practical lessons which the Puritans derived from their doctrine were also on the whole merely the same as those taught to the Catholics who were brought up to avoid the deadly sin of ambition. ${ }^{2}$

Nothing expressed the early doctrine of the "calling" more succinctly than Robert Crowley's verse:

Fyrste walke in thy vocation

And do not seke thy lotte to chaunge;

For through wycked ambition,

Many mens fortune hath ben straynge. ${ }^{3}$

Yet nothing could be further from the truth than to suggest that this verse introduced a new doctrine favourable to the rise of a "spirit of capitalism", or that the "calling" was an invitation to amass and continue to amass great riches.

When we remember the great use Max Weber has made of the doctrine of the "calling", it seems important that evidence should be accumulated to demonstrate what the earlier Puritan conception of the "calling" really was.

Thomas Lever was a sincere and godly Puritan reformer. In his Sermon preached at Paules crosse he gave an excellent exposition of the old principle of distributive justice under the guise of the "calling".

"Nowe", he said, "let vs after thys takynge of the mynisterye of Chryste, w(h)yich perteineth generally vnto all christians, speake of

I Weber, loc. cit. p. 70, n. I (Engl. trans. p. 21I). Does not this argument in any case suppose that St Thomas drew a keen distinction between the Lex naturae and the Lex divina? Whereas, in fact, he believed that the law of Nature was a manifestation of the Divine law. Also, in the passage quoted, he did subordinate natural causes to providence.

${ }^{2}$ Cf. Troeltsch, The Social Teaching of the Christian Churches, p. 555, on the Lutheran version.

3 Crowley, Voyce of the Last Trumpet, in Selected Works (Early English Text Society, Extra Series, xv, p. 55). 
the dysposers of Gods mysteryes, wherein we maye consider seuerally euery mans vocacion.

"Paule dyd dyspose the secretes of God by the preachynge of the Gospell, whych was euer secretly hydde from the wyttye, wyse, and learned in the worlde. Other men in other vocacions must dyspose other treasures of God by other meanes. As the magistrate by authorytye must dyspose the punyshmente of vyce, and the mayntenaunce of vertue.

"The rych man by liberalytye, must dyspose reliefe and comforte vnto the poore and nedye. The Marchaunt by byinge and sellynge, and the craftes man by his occupacion, must prouyde vnto the common wealthe of necessarye wares, sufficyente plentye. The landelorde by lettyng of fermes must dyspose vnto the tenants necessary lands, and houses of an indifferent rente. The housbandmen by tyllyng of the ground and kepyng of cattel, must dyspose vnto theyr landlordes, dew rentes, and vnto them selues and other, both corne and other vytals. So euerye man by doynge of hys dutye muste dyspose vnto other that commodytye and benefyte, whiche is committed of god vnto theym to be dysposed vnto other, by the faythful and diligent doyng of theyr dutyes." $\mathrm{I}$

This is the true interpretation of the "calling", and it savours little of the spirit of capitalism, but only of the medieval spirit of ordered status. Indeed, the preacher, in whose sermons the "calling" was a constant theme, thought it necessary to disclaim communist sympathies. ${ }^{2}$

When the early Puritans used the conception of the "calling" it was almost invariably in reproof of covetousness and ambition. Lever tried to invoke it against the land-hunger which brought with it large farms and evictions:

And the luste and desire of the Deuyll is, to hinder the worcke and pleasure of God: and thys is the worke and wyll of God, that we should repose oure faythe and truste in Christe Jesu, and bestowe oure laboure and diligence in our owne vocacyon.

I Thomas Lever, Sermons (1550) (Arber's Reprints, p. 106).

2 Ibid. p. 27. 
Therefore the deuyll poysonynge all hys wyth greadye couetousnes wyll cause them euer to trust to their owne prouision, and neuer to be content wyth their owne vocacion, but beynge called of God to be marchaunt, gentleman, lawer, or courtear, yet to be readye at a becke of their father the deuyl, besydes this their godly vocacion, deuyllyshelye to proule for, seke, and purchase farmes, personages, and benefices, to discourage housbandemenne from tyllynge of the grounde, and ministers from preachynge of Goddes woorde... .

Here we find the "calling", as usual, crying out against what is considered to be an abuse of the power conferred by wealth.

The advice of the sixteenth-century Puritan divines was always "Be content in your calling"; they believed that neglect of this advice was at the root of all the agrarian troubles of the time, because one man was not content with one occupation:

As for example of ryche men, loke at the merchauntes of London, and ye shall se, when as by their honest vocacion, and trade of merchandise god hath endowed them with great abundaunce of ryches, then can they not be content with the prosperous welth of that vocacion to satisfye theym selues, and to helpe other, but their riches muste abrode in the countrey to bie fermes out of the handes of worshypfull gentlemen, honeste yeomen, and pore laborynge husbandes....2

When Lever was condemning the evil doings of leasemongers, forestallers, regrators and the "Marchant of mys-. chyefe that by craftye conueyaunce for his owne gayne, caryeth awaye such thinges as maye not be spared, and bryngeth agayne suche wares as are not nedeful", he exhorted them to repentance by saying:

Take hede vnto your vocacions prelates and preachers, Magystrats and offycers, landlordes and tenaunts, craftes men and marchauntes, all maner of men take hede vnto youre selues and to your conuersacion and lyuyng.... 3

Invariably he employed the idea of the "calling". And his
I Ibid. pp. 49-50.
${ }^{2}$ Ibid. p. 29.
3 Ibid. p. I3I. 
teaching differed in no essential from that of the medieval Summae in which the bounds of lawful trade were discussed and the striving after immoderate gain reprobated; in which the exercise of "justice" in buying and selling was enjoined and some trade activities were designated as sinful or unworthy. These early English Puritans condemned, by means of the doctrine of the "calling", the same economic practices as Luther attacked in his Von Kaufshandlung und Wucher, as Catholics like Wimfeling attacked in their sermons preached in the busy South German towns. To these sixteenth-century divines at least, the "calling" was a conception to be employed on the side of conservatism in a period of economic change.

Lever was not alone in drawing such conclusions from his belief in the "calling". Those drawn by his fellow-preachers were the same. In the sixth of Hugh Latimer's sermons preached before King Edward VI he reminded his congregation that:

Oure Sauiour Christ before he began hys preachynge, lyued of hys occupacion, he was a carpenter, and gat hys liuynge wyth greate laboure.

He did not say this with any intention of encouraging the capitalistic spirit. It was with the intention of condemning idleness indeed; but to Latimer as to many another reformer, the capitalists were the idle rich, battening on surplus value. He was concerned with the dignity of labour, not with gain and ambition.

"Therefore let no man disdayne," he continued, "or thincke skorne to followe hym in a meane liuynge, a meane vocation, or a common callynge and occupacion. For as he blessed oure nature with takynge vpon hym the shape of man, so in hys doyng he blessed al occupacions and artes....

"It is lucre inoughe, it is vantage inoughe to be content with that, that God sendes. The fayethfull can not lacke, the vnfaythfull is euer lackynge, though he haue neuer so much."'I

I Latimer, Seven Sermons (Arber's Reprints, p. 180). 
Once more we find the "calling" employed to combat capitalistic ambition.

The "calling" was man's earthly state, allotted to him by God, and his opportunity for Grace. As a gift from God, it was a gift with obligations. Weber has stressed the point that the doctrine of the "calling" caused the Puritans to be diligent in their application to business, to the greater glory of God. But it was not only in a sober application to worldly toil, it was in every department of life that their acts were designed ad majorem Dei gloriam. It was from this broader conception of the "calling" that Latimer derived his saying:

For God gaue neuer a gyft, but he sent occasion at one tyme or an other to shewe it to Gods glory. As if he sent riches, he" sendeth pore men to be helped wyth it,

and it was with disregarding one's "calling" that such an opportunity was missed:

But now must men occupy theyr goodes other ways. They wil not loke on the poore, they muste helpe their children, and purchase them more land than euer their grandfather had before them. ${ }^{I}$

Nothing could be further from the truth than to suppose that the "calling" was an invitation to amass and continue to amass great riches. It was an invitation to live the orderly and settled life ordained for one by God, and to perform all the duties pertaining to it.

Robert Crowley was a militant Puritan, and one whose rhymes did much to further the adoption of the idea of the "calling". His writings are filled with this conception. Yet nobody could accuse this fearless champion of the poor, this fervent opponent of the active new social order, of any bias in favour of capitalism. In $155^{\circ}$ he published his Voyce of the laste trumpet...callyng al estats of men to the ryght path of theyr vocation. In this he set out to advise the reader as to the correct

I Ibid. p. 70. 
I THE PURITAN DOCTRINE OF THE "CALLING"

pursuit of his "calling". The general advice has been quoted above, ${ }^{\mathrm{I}}$ and the particular advice given to the various classes of men was in the same strain.

The yeoman, for instance ("thou that arte borne the grounde to tyll" as he was described), had to be obedient, content and charitable, had to

$$
\text { ...be ware }
$$

Of the desyre to be alofte:

For he that doth for honour care

Falleth in Sathans snares ful oft.

Haue minde, therfore, thyselfe to holde

Within the bondes of thy degre,

And then thou mayest euer be bold

That God thy Lorde wyll prosper the.

And though the Lord geue the plentye

Of corne, cattell, and other thynge,

Be thou neuer the more gredy,

Nor set thy mynd on gatheringe.

But thinke the Lorde both these thynges sende

To the, as to his stuard true...,

and,

... when thou hast sufficient

Of fode and honest apparayle,

Then holde thy selfe therwyth contente....

If he dared to forsake his "calling" he was threatened with damnation.

Crowley's advice to the merchant-on whom the alleged influence of the "calling" as a stimulant of the spirit of capitalism should presumably have had the greatest effect-was of a similar nature:

Nowe marke my wordes thou marchaunte man,

Thow that dost vse to bie and sell,

I wyll enstruct the, if I can,

How thou maiste vse thy callynge well.

see above, p. 7. 
Fyrst se thou cal to memori

The ende wherfore al men are made,

And then endeuour busily

To the same ende to vse thy trade.

The ende why all men be create,

As men of wisdome do agre,

Is to maintaine the publike state

In the contrei where thei shal be.

Apply thy trade therfore, I sai,

To profit thy countrey with al;

And let conscience be thy stay,

That to pollinge thou do not fal....

The merchant who followed his "calling" dutifully had to sell his goods at the just price, thinking more of his country's benefit than his own; he had to avoid hoarding, lending for unlawful gain, and above all he had to avoid stepping completely out of his "calling" to enjoy the profits, of sheepfarming. If he did all this, said Crowley,

... in the ende, when nature shall

Ende thy peregrination,

Thou shalt haue ioye emonge them all

That walkt in theyr vocation.

But if thou do refuse to walke

In thy calling, as I haue tolde,

Thy wisdome shalbe but vain talke,

Though thou be both auncient and olde.

Say what thou wylt for to defende

Thy walkynge inordinately,

Thou shalt be certen, in the ende,

To be damned eternally.

For in the worlde ther can not be

More greate abhomination,

To thy Lorde God, then is in the

Forsakeyng thy vocation. ${ }^{\text {I }}$

I Crowley, Voyce of the Last Trumpet (loc. cit. pp. 53 ff.). 
It would be easy to multiply instances of the use of the conception of the "calling" as a basis for pronouncements of this sort. Weber very rightly stressed the importance of the vocation or "calling" as a fundamental part of the Puritan ethical system, but he painted a very misleading picture of what it meant. If it encouraged industry, it did so to a much smaller degree than it discouraged covetousness and ambition-the ambition which made men break out of their "calling", which would not let them be content with one "calling" but made them try to engross the livelihoods of many into their hands. It was by the doctrine of the "calling", the doctrine that every one should have one settled life-task, that Crowley condemned the enclosing landlords, the graziers, the leasemongers of his day:

Of good maisters, what should I cal you? You that haue no name, you that haue so many occupacions \& trads that there is no name mete for you! You vngentle gentlemen! You churles chikens, I say !x

He had little good to say of those whose enterprise overstepped the bounds of a "calling" in so shameless a way.

The "calling" did not embody a progressive ideal. The demand for an ordered life, for an innerworldly asceticism, which Puritanism made and expressed in the conception of the "calling" had no message of a capitalistic nature to give the world. It placed in the forefront the age-long static ideal of content with the decrees of providence; as the author of a typical seventeenth-century theological treatise put it:

Then ye Common-wealth is blessed, and all ye Citizens therof happie; when every one knoweth his own vocation and diligentlie doth ye Duties thervnto belonginge; and giues others their place, \& breake not out of ye bounds of their owne Callinge. ${ }^{2}$

Yet Weber has not misconceived the Puritan "calling". His

x Crowley, The Way to Wealth (loc. cit. p. 143).

${ }^{2}$ Brit. Mus. Add. MSS. 12,515, pencil folio 35 back. 
description of the doctrine is exact-but not for all time. A mistake lies in the assumption that the "calling", as a guide to the conduct of life, has meant the same thing throughout its history. He has only studied the later phases of the doctrine. In the latter part of the seventeenth century and in the eighteenth he has found numerous examples of Puritan literature counselling a course of worldly prudence as a religious exercise, as the fulfilment of a "calling". He has projected the prudential character of this doctrine backward as having always been an essential element. Owing to his unhistorical treatment he has not noticed the change in the conception of the "calling" from an antidote against covetous ambition to a comfortable doctrine suitable for a commercial people. He has treated the doctrine as having been the same for all time; and the adherent of the school of "economic determinism" may be excused if he criticises Weber for neglecting the converse study of the influence of capitalism on the Protestant Ethic.

The development of the new prudential conception of the "calling" (which did not become general until the eighteenth century) may be traced quite easily in the three most influential manuals of Christian conduct of their respective ages-The Whole Duty of Man of 1657, Baxter's Christian Directory of 1673, and the New Whole Duty of Man which appeared first in the reign of George II and retained its popularity for over a century.

The first of these manuals was produced as an antidote against solifidianism. It affirmed strongly, therefore, the necessity for good works and re-asserted the need for a strict application of the customary ethical system.

Baxter occupies a much less decided position. His work stands half-way between the wholly traditional morality of the first Whole Duty of Man and the freer mode of the second. Weber quotes it largely in support of his thesis; yet the real conservatism of its position is very apparent. ${ }^{I}$

I On this cf. Brentano, Die Anfaenge des modernen Kapitalismus, p. I43; Tawney, Religion and the Rise of Capitalism, pp. $220 \mathrm{ff}$. 
Every one, it is true, was under the necessity of living in a "calling" in which he might redeem his time. But the spirit of gain was not to be allowed as a guide to choosing one's "calling":

Choose that employment or calling, (so far as you have your choice) in which you may be most serviceable to God. Choose not that in which you may be most Rich or Honourable in the world; but that in which you may do most good, and best escape sinning. ${ }^{\mathrm{I}}$

One was exhorted to choose the "calling" which most conduced to the public good; only in cases where there were two "callings" equal in this respect might there be any doubts as to which must be chosen, and in this case it was important to choose the one which might be followed with the greater advantage to one's soul, not the more gainful. ${ }^{2}$

Baxter was at pains to point out that:

If you have a necessity of labouring in your callings, you have no necessity of loving the world or caring inordinately, or of being discontented with your estate. 3

He also seems to have been very far from the belief that to grow rich in a "calling" was a sign of grace:

Another thinks he is no worldling because he useth no unlawful means, but the labour of his calling, to grow rich. The same answer serves to this. The love of wealth for the satisfying of the flesh is unlawful whatever the means be. 4

It must be allowed, then, that even Richard Baxter's conception of the "calling" was not a very whole-hearted influence in favour of capitalism. He accepted the purposive philosophy of the social idealist rather than the mechanistic one of the individualist, and so he insisted on giving moral advice as to the conduct of business affairs:

I Baxter, Christian Directory (tome I, ch. iii, s. 23, direction 20), edition of 1678 , vol. I, p. 133 .

${ }^{2}$ Ibid. 1, pp. $447 \mathrm{ff}$.

3 Ibid. I, p. 256.

4 Ibid. I, p. 256. 
The public welfare, or the good of many is to be valued above our own. ${ }^{\mathrm{I}}$

Regard the public good above your own commodity. It is not lawful to take or keep up any oppressing monopoly or trade; which tendeth to enrich you by the loss of the Common-wealth or of many. ${ }^{2}$

As a result Baxter retained many of the older canons of business dealings. He disapproved of the maxim Caveat Emptor and he tended to advise a modified doctrine of Just Price being maintained. He said that in buying and selling one should

... have special respect to the common estimate, and to the market price. Though it be not alwayes to be our Rule, yet ordinarily it must be a considerable part of it; and of great regard.

Further, he stood wholeheartedly on the side of the objective determination of the just value, quite in the medieval manner:

But if that which you have to sell, be extraordinarily desirable, or worth to some other person, more than to you or another man, you must not take too great an advantage of his convenience or desire.

It is true that in this matter he showed himself ready to make some compromise-he would allow a greater price to be exacted of the rich than of the poor, and he believed that some latitude must be allowed in determining the just price, as "to be alwayes just at a word is not convenient"'. But the general tenor of his advice was in favour of fixing rules for trade which were inconsistent with a simple search for gain; the contention that his influence lay in promoting the rise of a spirit of capitalism must be accepted with considerable reserve. ${ }^{3}$

It is only in his treatment of subordinate matters that the other Baxter appears-and this is the Baxter who is furthest from the old Puritan and nearest to the Jesuit, the commonsense confessor or spiritual adviser of a workaday flock. In

I Ibid. I, p. 448. $\quad{ }^{2}$ Ibid. Iv, p. I 13. $\quad 3$ Ibid. Iv, ch. xix, passim. 
many ways Baxter was not averse from supporting the honest business man. He believed in the latter sticking up for his own rights; he had not to allow himself to be cheated or to let the ungodly triumph over him in worldly affairs.

"Others", he said, "are thought covetous because they lawfully and peaceably seek their right, and let not the unjust and covetous wrong them at their pleasure. It's true we must let go our right when ever the recovering of it will do more hurt to others, than it will do us good: but yet the laws are not made in vain: Nor must we encourage men in covetousness thievery and deceipt by letting them do what they list. Nor must we be careless of our masters talents: If he intrust us with them, we must not let every one take them from us to serve his lusts with."I

He did not believe, like the earlier Puritans, that the practice of engrossing and enclosing lands was wholly condemned by the doctrine of the "calling". He was no friend of the landlord class - he was firmly opposed to rack-renting, and in this connexion had quite rightly pointed out that a landlord could be an oppressor whilst taking no more than the full worth of his land ${ }^{2}$-yet he was realist enough to see that moral judgment might only be pronounced on many practices (including engrossing) on the basis of their economic effects:

Question. May a rich man put out his Tenants to lay their Tenements to his own Demesnes, and so lay House to House and Land to Land?

Answer. In these two cases he may not: I. In case he injure the tenant that is put out, by taking that from him which he hath right to, without his satisfaction and consent: 2 . And in case it really tend to the injury of the Common-wealth, by depopulation and diminishing the strength of it: Otherwise it is lawful: and done in moderation by a pious man may be very convenient:

I. By keeping the land from beggery through the multitudes of poor families that overset it: 2. By keeping the more servants among whom he may keep up a better order, and more pious

I Baxter, op. cit. I, p. 257.

2 Ibid. Iv, pp. 139-40. 
government in his own House (making it as a Church), than can be expected in poor families: And his servants will (for soul and body) have a much better life, than if they had married and had families, and small Tenements of their own: But in a Countrey that rather wanteth people, it is otherwise. ${ }^{\text {I }}$

Thus he rather guardedly approved agrarian capitalism; in a manner, also, which might be applied to justify the growing movement for a capitalistic control of industry.

It might also be said that the chapter on " Redeeming or Well Improving Time" 2 was favourable to the capitalistic spirit, but the extent to which this was the case is doubtful. Too much importance has generally been given to the bourgeois virtue of diligence as an influence formative of the capitalistic spirit, and to the part played by Puritanism in creating this virtue. Indeed, this chapter seems in part to be an attempt to show that there are other things than business in which diligence pays; it gives one the impression that the spirit of capitalism was already strong in Baxter's readers, and Baxter was trying to show to good business men the importance of being also good Christians. 3

Occasionally Baxter seemed to encourage the idea that if God had placed before one the opportunity of following a profitable employment, $\mathrm{He}$ would have had His reasons for doing so. One of the answers to the question whether it was lawful to live in an infidel country was:

It is lawful for a well qualified person who desireth Riches to serve God, and to do good with, to go in a way of trading, though he be in no poverty or necessity himself. Because Gods blessing on lawful Trade may be desired and endeavoured, and he that should

I Ibid. Iv, p. I42.

2 Ibid. I, ch. v.

3 For example: "In Merchandize, or any trading; in husbandry or any gaining course, we use to say of a man that hath grown rich by it that he hath made use of his Time! But when Heaven, and communion with God in the way, and a life of holy strength and comfort, and a death full of joy and hope is to be the gain, how cheerfully should Time be Redeemed for these?" (Ibid.) 
do all the good he can, may use what lawful means he can to be enabled to do it. ${ }^{\text {I }}$

He expressed the same thought even more fully in a reply to a question as to the proper nature of worldly endeavour, in which he claimed that one should choose a gainful "calling" rather than another if alternatives offered. ${ }^{2}$

This, however, must be offset against the advice not to choose the more gainful "calling" when another would be of greater public service or would provide a better moral discipline. ${ }^{3}$

It will be seen that Baxter spoke with an ambiguous voice. His rather complacent advice on the special duties of the poor was very like the old doctrine of being content with the state into which it had pleased God to call one, and was not conducive to ambition. 4 It may be argued, of course, that the Puritans did not preach the doctrine of capitalism to every one, and that this advice to the poor, leading to a greater docility amongst labourers, was of importance in aiding the capitalistic strivings of the elect. To argue in this manner, however, suggests an undue reliance on being able to have one's cake and eat it.

I Baxter, op. cit. IV, p. I3I.

2 Ibid. rv, pp. 146-7:

" $Q$. Is it a duty to desire and endeavour to get, and prosper, and grow rich, by our labours; when Solomon saith, Labour not to be rich? Prov. xxiii, 4 .

"Answ. It is a sin to desire Riches as worldlings and sensualists do, for the provision and maintenance of fleshly lusts, and pride: But it is no sin, but a duty, to labour not only for labour sake, formally resting in the act done, but for that honest increase and provision, which is the end of our labour; and therefore to choose a gainful calling rather than another, that we may be able to do good and relieve the poor."

Medieval Catholicism also, however, stressed the duty of gaining sufficient property and of refraining from squandering it through excessive generosity. Cf. Troeltsch, The Social Teaching of the Christian Churches, pp. $319 \mathrm{ff}$.

3 See above, p. 16.

4 Baxter, op. cit. II, pp. 629-30. 
It must remain open to dispute whether the most characteristic feature of Baxter's writings was his respect for the traditional morals which the Churches had agreed in applying to the conduct of business, or his practical feeling that the good business man was not necessarily a bad Christian, and his readers are likely to decide the matter according to their own predilections. But of one thing we can be certain-that his favour shown to the business man was not the result of his Puritanism. It was the result of being, through his exceptional relations with his congregation, ${ }^{\mathrm{I}}$ bound up with the practical life. It is impossible to regard Baxter as lending a wholehearted support, either to the capitalistic or the old traditionalist side. He was not a leader; he was trying to reconcile the Christian and the commercial life, as St Thomas had tried in the thirteenth century. ${ }^{2}$ But he had to make greater concessions to the commercial spirit than Aquinas, and, being a man of his age, he probably made them more easily.

When we come to the book of Christian conduct which succeeded Baxter's in popular esteem, we find that the movement towards looking through business spectacles has made rapid progress. The New Whole Duty of Man, containing the Faith as well as Practice of a Christian: Made Easy for the Practice of the Present Age... was also undecided in the guidance it offered with regard to some of the economic duties. But on the whole it made greater and more numerous compromises with Mammon. The work bore still evident traces of the old traditional morality - how long it lasted! - such as are exemplified in these "Rules of Traffick":

... Neither ask far beyond, nor bid much below, what reason must inform you to be the real worth.... Do not impose upon any man's unskilfulness or ignorance. So long as you keep within the latitude of lawful gain, you may use your skill against another man

I Baxter was one of the first Puritan casuists, his Christian Directory being based on the problems of conscience on which he had advised his congregations during his ministry.

2 St Thomas Aquinas, Summa Theologiae, ii-ii, qu. 77. 
in driving a bargain: for in an ordinary plenty of commodities there is an ordinary price, which those that deal in them know and understand; and when the contractors equally understand the price, there can be no deception or injustice in the contract, be it made ever so hard. On the contrary, if he whom I contract with be ignorant or unskilful, I must not rate his want of understanding, or set a tax on his ignorance, but use him justly, as one that reposes a trust in me, and casts himself upon my equity; for if I do not this, I am guilty of injustice.

The same may be said where a man takes advantage of another's necessities. When a poor man is driven by his wants, and forced to sell his wares to supply his necessities; give him the price you would have done, if he wanted your money no more than you need his goods. On the other side, if the poor man be forced to buy upon trust, increase your price no higher than what makes you recompense for the loss, which by the rules of trade, you sustain by the credit you give him; because he who makes advantage of another's necessities, adds oppression to misery; which is not only injustice but cruelty... . Moreover be not guilty of engrossing, or buying all of a commodity into your hands, with the sole view of selling it the dearer and thereby to oppress or distress the publick. Neither let the people curse thee for being the first that hath raised the price of goods... a good and quiet conscience is to be valued above the greatest gain.... 1

In spite of this surface conservatism, however, the $N e w$ Whole Duty bears the mark of being, as the title says, "made easy for the practice of the present age". It is recognised that with time's changes new codes of moral guidance were called for, and that the first Whole Duty of Man was not "(by any means) suited to the present times; for how can it be? it having been written near one hundred years since".

When the New Whole Duty discoursed on honesty, it dealt quite literally with nothing else than the advantages of honest dealing to a nation of shopkeepers. It delivered a long homily on "Honesty is the Best Policy":

I The New Whole Duty of Man, 2oth ed., pp. 269-70. 
The usual bait of injustice is gain and profit: this is the common mark that fraud and oppression aim at, though usually they fly short or beyond it, and, instead of enriching, do finally damage and impoverish men. It is indeed known, that unjust dealing may sometimes raise a man's fortune; but it is as well known, that in its natural tendency it impairs and ruins it; because, by dealing unjustly, he makes it every man's interest to forsake him, and sets a cross upon his own door to warn all customers from entering therein. Is it reasonable to suppose, that any one would knowingly have anything to do with a knave, that always lies upon the catch to cozen him; with whom he can neither speak nor act securely, but must be forced to stand upon his guard continually? Or how can a man thrive, when no-body cares to deal with him; when his house is haunted, and his frauds and cozenages appear like sprites at his door, to frighten all men from his shop? So you see that justice in dealing is so necessary to men's thriving in the world, that even they who are not honest are fain to seem so: but for a man to seem to be honest is no way so secure as to be really so; for, if he be not, the event of things will unmask and set him out. For no man can be secure of privacy in an unjust action; let him carry it ever so demurely, one accident or another will draw the curtain, and bring to light the fraud and villainy behind it: so that, how much soever a man may gain by a present cheat, he is sure, if he be discovered, to be a loser at the last. Injustice is as great an error in politics as in morals, and doth bespeak a man to have as little wit as honesty. The sum therefore is briefly this: he that in the whole course of his life acts sincerely and justly, with a continual respect to the reason of things, and to the law of God; that carries on all his undertakings by fair and equitable means, avoiding all frauds and deceipts, all base and unworthy practices; this man takes the wisest and surest course to succeed in all his designs, respecting either his present or his future happiness. ${ }^{\mathrm{I}}$

The author of the New Whole Duty treated of diligence in a way very different from Baxter. He was entirely matter-of-

I Ibid. pp. 271-2. 
fact, praising its advantages in much the same manner as he might have extolled those of the division of labour:

Moderat labour has advantages that servants do not think on; it makes their necessary service in time grow easy; for as repeated acts beget habits, and things habitual become easy and familiar to us, so continued labours, if done with moderation, when sirength and pains are discreetly proportioned out, beget activity, which cannot be long idle. So industry is truly the servant's interest, as well as the master's; for such as have served with industry and diligence, are secure of better credit and more success in their after-life... . I

By the time of the New Whole Duty of Man the doctrine of the "calling" had lost its early character of an antidote against ambition. The author did not see in it any ban on enterprise. In his discussion of the duty of servants he wrote that:

The state of servitude is necessary by the appointment of the wise Creator; the world cannot be governed and maintained without it; and it is their lot to be instrumental to the publick good in that state of life. Yet this is no token of God's displeasure: for, he in no wise forbids them to use honest means to make themselves free as soon as they can....2

It was a different outlook from Crowley's "And do not seke thy lotte to chaunge".

The author of the New Whole Duty was amongst the first of the English moral writers to consider that worldly success was of great moment, and of paramount importance in deciding in what esteem a man should be held:

... As titular dignities intitle men to an outward respect and observance, so also doth wealth and large possessions; for, when God bestows upon one man a larger fortune and possession than on another, he doth thereby prefer and advance him into an higher sphere and condition; and when God hath set him above us, it is just and fit that we should rise and give that place to him which is of God's appointment. Though, it may be, a wise or virtuous poor

x New Whole Duty of Man, p. 239 .

2 Ibid. p. 240. 
man hath more right to our esteem than a fortunate knave or fool; yet, forasmuch as in outward rank or condition God hath preferred the latter, he hath the rights of precedency, and of outward respect and observance; and ought to be treated with greater regard and obeisance. $\mathbf{I}$

A very typical and significant illustration of the part which religion had come to play in the mind of the author of the $N e w$ Whole Duty may be found in his attitude to those who leave their "calling" "under a pretence of purer religion":

... hereby they are not only rendered useless to the commonwealth, but they do oftentimes a great deal of mischief to it, by unsettling and subverting other men, and filling their heads with abundance of foolish notions and scruples in religion, which are dangerous to government, and the publick peace and happiness... the man that serves God by continual application to the duty of his calling and state of life, besides the comfort of a good conscience, which is of all others the greatest happiness, such an honest and industrious labourer may entirely depend upon the goodness of God, that he will always take care of him: God will bless and prosper him in the work of his hands....2

It is evident that the influence of this book was in favour of the rise of a spirit of capitalism, and it is on evidence such as this that the assertions have been made that Puritan doctrine has resulted in the growth of the capitalistic spirit. There has been a complete lack of historical method.

It was not till the eighteenth century that the commercial ethics of English Puritanism reached this point. ${ }^{3}$ Even then the old conservative views were not entirely lost. They were found still scattered on the pages of the $N e w W$ hole Duty. 4 They were

I Ibid. pp. 293-4.

2 Ibid. pp. 365-6.

3 The book is really Anglican rather than Puritan. It may even be that the stress on the respect due to wealth is derived from Anglican "squirearchical" beliefs.

4 See, for example, the "Rules of Traffick" quoted above, or these passages in the New Whole Duty:

p. 42: "In all circumstances of life therefore, we are not to be uneasy 
found even more strongly expressed in the writings of Defoe, a Nonconformist as well as an author of books on commercial practice. As an example of the way in which the old feeling against overstepping one's "calling" still persisted even amongst the commercial classes, we might take Defoe's comment on some new practices which were just creeping into the cloth trade. Describing the usual organisation for the distribution of cloth, Defoe said that a piece of cloth woven at Warminster in Wiltshire and made up by C., a Northampton tailor, into suits for D. E., Esq., and other country gentlemen, would formerly have been sent by carrier from Warminster to London to Mr A., the Blackwell Hall factor, who sold it to Mr B., the wholesale woollen-draper, who sold it to $\mathrm{Mr}$ C., the shopkeeper at Northampton, whither it was carried from London by the Northampton carrier. Thus four families of tradesmen were supported by the trade in the cloth before it reached Mr C. at Northampton.

But now here is Mr F. G., another shopkeeper at Northampton, who having more money than his neighbours, and wanting no credit, he finds out where these cloths were made, and away he goes to Warminster directly, settles a correspondence with the clothiers there, buys their goods, and has them brought directly by horse-packs to Northampton.

In this way he managed to get his cloth half-a-crown a yard cheaper than C., and so to filch away all his custom. In the process he ruined $\mathrm{Mr} \mathrm{C}$. and also the Warminster carrier, the

that God has made us inferior to others... or that He has given us less abilities or fewer opportunities.... Even poverty is not an argument to envy the rich; but a strong obligation to study the duties of humility, contentment and resignation...."

p. 327: “... self-love, which being an immoderate love of our own worldly interests, is the foundation of all contention and injustice."

p. 343: "As for the goods of fortune, which are wealth, honour, \&c., we have no reason to be proud of them; because they add no true worth to a man...." 
Northampton carrier, Mr A., the Blackwell Hall factor, and Mr B., the wholesaler.

And what's all the benefit which is made by this spoil upon trade? Only this, to make one covetous man rich; and that 'Squire $\mathrm{D}$ _ E E — of Northamptonshire may buy his suits of cloaths so much a y.ard cheaper.... ${ }^{r}$

It was only in a long progress of time that English Puritanism came to be favourable to the claims of commercial men-that the doctrine of the "calling" ceased to be a Puritan antidote against the temptations of ambition. This fact is insufficiently recognised; and it shows the dangers of trying to explain historical developments without having recourse to historical methods. The shopkeepers' morality of the eighteenth-century New Whole Duty of Man is, properly understood, an argument against the thesis which connects the Protestant ethic with the spirit of capitalism; an argument for seeking in social changes the reasons for alterations in religious outlook. In the argument that Calvinist and Puritan Protestantism has provided the religio-sociological background for the rise of the capitalistic spirit too much has been made of those numerous passages in the Works of the Puritan Divines and the writings of later Americans $^{2}$ which condemn idleness by virtue of the doctrine of the "calling". There are many passages to be found in the same Works of the Puritan Divines which condemn covetousness and ambition in accordance with the same doctrine; and many more among the works of these writers' forerunners. The doctrine of the "calling" did not breed a spirit of capitalism. The spirit of capitalism was responsible for a gradual modification and attrition of the Puritan doctrine; and this attrition had barely begun in England before the Restoration.

When one glances at the state of affairs on the continent of

I Defoe, The Complete English Tradesman, ch. xxxvii, ed. of 1738.

${ }^{2}$ Much use has been made of the writings of Benjamin Franklin in advancing this type of argument. For my criticism of this evidence see below, pp. I6I ff. 
Europe, the conviction is deepened, that serious misconceptions of the nature of the relations between religious ethics and the spirit of capitalism have arisen. Generalisations have been too hasty.

One finds amongst the Catholics, both Jesuit and Jansenist, doctrines favourable to the emergence of the steady type of business man who was in favour with the later Puritans. The Catholics employed doctrines cognate with that of the "calling" with the same practical effect. "One must rise, for example", said the Jansenist Nicole, "to obey God, Who only allows us sleep for the body's needs and commands us, when these needs are satisfied, to busy ourselves with the work which He prescribes for us according to our state."I

The Jansenist preachers in particular reminded their flocks that the Christian life was "a serious life, a life of toil and not of diversion, play or pleasure" so that one ought never to forget that it "should be filled with some useful and sober occupation suitable for one's state of existence"."2

The Jesuits stressed almost the same beliefs. Little could have been more favourable to a rational methodising of life than Father Crasset's panegyric on Order:

Order and virtue are two words which mean almost the same thing. It is order which makes Paradise, and disorder, Hell.... Everything which God makes, He makes orderly, and everything that is not made in an orderly manner is not of God. Order leads us to God. 3

In France the Church went out of its way to welcome the honest bourgeois - the self-made man-on the ground that he was the only type of man who followed God's commands and lived in a "calling". It is true that the phrase was not employed, but the idea was:

I Quoted in B. Groethuysen, Origines de l'esprit bourgeois en France, I (L'Église et la Bourgeoisie), p. 196.

2 Ibid. p. 197. Also quoted from Nicole.

3 Ibid. pp. 198-9. 
Do not seek true piety among the great, the noble, the rich, whose life is only amusement and luxury; and do not expect to find purity of behaviour amongst them. Where then may one find it? In the huts of a donothing poverty, which has no occupation but begging? No, Christians: they as well as the rich are lost through idleness, and this class of the poor, whom Jesus Christ does not recognize, are also given to disorder. To whom then is purity reduced? I have told you-to these middle states of life who subsist by work, to these less noticeable conditions of men, who are however more assured of salvation, merchants engaged in the cares of lawful business, workmen who measure the days by the labour of their hands, servants who fulfil to the letter this divine command: as ye work so shall ye eat. ${ }^{x}$

The Catholic Church was forward to reduce all the duties of a Christian to the due performance of his earthly tasks. The Catholics also tried to consecrate the world of labour, even to make it the only world that mattered:

All your piety is included in your station ${ }^{2}$ and duties. I say: in your tasks faithfully observed. Do not neglect anything that is required by your employment, your bidding, the different relations you enjoy most directly, whether with God, as ministers of altars, or with the public as judges, or with servants in virtue of being masters, or with children as fathers and mothers; it does not matter with whom or how-include everything, accomplish everything, neglect nothing. ${ }^{3}$

It was easy to serve God in this indirect way by performing all one's worldly responsibilities with a sober sense of duty:

One serves God by faithfully serving one's Prince; one serves God by employing one's capital (en faisant valoir son bien) according

I Ibid. p. 200 (Father Bourdaloue).

2 If it were not for the risk of being accused of trying to support my argument by inserting in the translation words which are not in the original I should be tempted to translate condition here as "calling", not as "station". It would be the only satisfactory translation. It would also suit charge a little lower down, which I have translated as "bidding".

3 Ibid. p. 20I (Bourdaloue). 
to all the rules of probity and justice. There are duties to be performed in all conditions of life, and it is in acquitting oneself of these duties that one is sanctified. ${ }^{\mathrm{I}}$

The French Jesuits even claimed that there was no incompatibility between self interest and the service of God:

God deigns to be grateful to us for what is done on our own behalf, if it is for the love of Him that one does it. So there is no incompatibility of service and business. One is soldier, lawyer, business man, but one is also a Christian. One can serve the same master in all these different states, and one can work fruitfully for God, for men and for oneself. ${ }^{2}$

It might just as easily be claimed for Catholicism as for Puritanism that it made a demand for a worldly asceticism of rational toil. The spirit of Christianity, said the Abbé Réguis, "is a spirit of order and activity, of prudence and precaution, of fear and trepidation, because of the temptations of every sort to which we are exposed, and against which it is impossible to defend oneself if one lives an idle and unproductive life". 3

And so the ordered life which would be recommended by a Puritan by virtue of the doctrine of the "calling" was also recommended by the Catholics. By them also it was stressed as a religious exercise, and the due performance of its discipline was recognised as a mark of grace:

When all is ordered, and one does everything in due time, one acts as a Christian, and it is by this means that many become sanctified and perfect.... Often they can only be distinguished from others of the same occupation by the application and the nicety with which they perform their tasks; they only do the same as all the others, but do it with an exactitude which takes the place for them of greater and more beautiful actions. 4

The necessity of worldly labour was incumbent upon the

I Groethuysen, op. cit. p. 203 (cited from Houdry, La Bibliothèque des Prédicateurs).
2 Ibid.
3 Ibid.p. 218.
4 Ibid. p. 205 (cited from Houdry). 
Catholic as well as the Protestant rich, in the days of the eighteenth century:

Since we-are all sinners by birth, we are all included without exception in the decree which condemned Adam to work, sickness and death. As neither rank nor riches, then, discharge anyone from the necessity of death, no one ought to believe himself to be relieved of the obligation to work under pretext of being of distinguished rank or of not requiring to work in order to live. ${ }^{I}$

After a time, also, the belief that labour is a curse fell out of fashion, and it was stated instead that:

The necessity of working is not a penalty; it is the decree of a Father Who makes all creation tributary to our needs. ${ }^{2}$

It was not only recognised by the French Church that it was favourable for business to have these doctrines; it was stressed that this was so, in an attempt to secure the goodwill and support of the commercial classes. "Religion, in making a sacred duty of work and a sin of idleness, is the soul and the nourishment of useful industry", was the actual claim of a Catholic preacher, de Boulogne. ${ }^{3}$

Thus there was nothing exceptional in the Church doctrines of the later seventeenth-and eighteenth-century Puritans. They were shared by the Catholics, and the encouragement given by them to the capitalist spirit was not the contribution solely of the Puritan and Calvinist sects. They did not develop until the end of the seventeenth century, when they spread both amongst Protestants and Catholics. 4 It would appear that this is in itself enough to prove that the problem has been viewed

I Ibid. p. 215 (quoted from Mésenguy).

2 Ibid. p. 2 I6.

3 Ibid. p. 2 I 4.

4 It is true that the examples from the French Jesuits which I have quoted from Groethuysen are on the whole rather later than the Puritan examples quoted by Weber from England. But the rise of a middle class who had to be accommodated came earlier in England than in France, and most of these eighteenth-century French writings are earlier than those of Franklin. 
through the wrong end of the telescope-to show that the chief relation between the rise of the capitalistic spirit and the Protestant Ethic is the reverse of what Weber has indicated. The Protestant Ethic changed as the result of the influence of a rising capitalistically-minded middle class. The Churches of the Calvinists and the Puritans did not always bear the same witness as regards the duties of the man of business. A changing emphasis, reflecting a changing spirit of the age, transformed a doctrine outwardly uniform. From being a hindrance to enterprise it became a spur.

The same change of emphasis took place among the Catholics. Was this due in some obscure way to the influence of the Protestant Ethic? We must think so, if we believe that the Protestant Ethic was the efficient cause of the rise of the spirit of capitalism. Or did both transformations take place under the same influence-the growing strength of an independent spirit of enterprise. The choice of hypothesis can hardly be in doubt. 


\section{Chapter II}

\section{PRE-REFORMATION CAPITALISM}

If it is true that modern capitalism is the product of a new spirit of capitalism introduced with the Reformation, it must necessarily follow that there was no capitalism before that time.

In so far as we can think of the Middle Ages as a unity, we tend to think of them as a period from which capitalism was largely absent, and if we were to indulge in the habit of dividing history into hard and fast stages, we should be tempted to speak of the Middle Ages as being characterised by a pre-capitalistic stage of economic development. But it is only by concentrating on the static general view that such a conception is possible. If one looks at the changing elements of medieval life one receives a different impression.

The typical medieval conception of social relations was that the life and activities of the individual should be regulated according to certain pre-conceptions of a Divine ordering of society - a graded society. The principles of medieval life were quite in accordance with this doctrine. In the country there was the authoritarian feudal system, with its clearly marked ranks and well-known customary duties. The general principles of town life (though they were of necessity a little more individualistic) were found chiefly in monopoly-or exclusive rights of buying and selling - and in the regulation of trade by authority. Both in town and country a sort of egalitarianism was mixed with the principle of well-marked class distinctions. Men were regarded as members of functional groups within each of which there was a rough equality of material conditions. All this is saying very little more than that one inevitably thinks of manor and gild when one thinks of medieval economic life. 
It was opposed completely to the individualism which is the basis of all that is best in capitalism. I It is not true, as too many writers nowadays suggest, that the difference between the individualist scheme of life and the typical medieval or the typical socialist scheme of life is that the individualist has no social ideals while the others have. What is true is that the individualist has different ideals. Individualism, as a doctrine, sees in the individual and his psychological aptitudes the necessary basis of society's economic organisation, believes that the actions of individuals will suffice to provide the principles of society's economic organisation, seeks to realise social progress through the individual by allowing him all the scope for his free selfdevelopment which is possible. It believes that for this two institutions are necessary: economic freedom (that is, freedom of enterprise) and private property. It believes that different individuals have different aptitudes and that each should be allowed to develop them in competition with others to the best of his ability. Therefore, as a system, individualism is the system of free trade, of competition, of private property. As doctrine and system it is entirely opposed to the typical medieval scheme of life. Only the regime of private property is common, and the medieval attitude to property was not the same as that of the modern world.

Nevertheless, the Middle Ages were never completely medieval in this sense. The medieval scene and the medieval mind had each of them elements of change, which grew and became more important, until finally they transformed medieval life. These are the elements which are of greatest moment to the historian, who is interested more in the physiology than in the anatomy of society. However flat and uniform the Middle Ages may have been, they contained currents flowing straight into modern times. Capitalism, even if not generalised, was not uncommon in the Middle Ages. It will be difficult, then, to look on it as the product of the Reformation.

r Unfortunately, mere "capitalism" rarely rids itself of the desire for monopoly. 
Sombart, like Weber, believes that modern capitalism is the product of a specific "capitalistic spirit", which found no place in the Middle Ages. He affirms that the principle of economic life in the Middle Ages was the provision for one's needs (the Bedarfsdeckungprinzip) which he contrasts with the pursuit of gain (the Erwerbsprinzip) that is the principle of modern capitalistic life. I He defines capitalism as "a definite economic system which may be recognised by the following characteristics: it is organised on the basis of exchange, and in it two different classes co-operate; the owners of the means of production, who direct operations, as subjects of the system, and propertyless labourers pure and simple as objects. It is ruled by the principle of gain and economic rationalism". 2 The definition seems very just; but it does not show why the whole of the Middle Ages should be considered pre-capitalistic. All these characteristics can be found there.

The Erwerbsprinzip is not a modern invention. We have lived in an acquisitive society for some thousands of years. Modern capitalism is not distinguished by exclusive possession of this principle. 3 Aristotle had indeed long ago brought it

I W. Sombart, Der moderne Kapitalismus, passim.

2 Ibid. I, p. 3 I9.

3 Cf. Brentano, "Versuch einer Theorie der Beduerfnisse", in Konkrete Grundbedingungen der Volkswirtschaft, p. 168.

"...Economic stages and economic forms are not distinguished psychologically through the finiteness or indefiniteness of wants. It is not the fact, as Marx and after him Sombart have said, that the characteristic feature of the capitalistic period consists in the striving for gain in it aiming higher than the standard of personal needs, while in earlier times it has halted at this limit. The desire for goods over and above the measure of personal requirements is not something impersonal which arises from the nature of capital. It is personal in the highest degree, for it is the emergence of the need for recognition by others, for power and esteem. It does not first come to light in the capitalistic economic period; it is common to this and all previous ones. Economic periods are not divided psychologically through the limitation or infinity of wants, but through the principles of production which are in vogue in them, and according to which therefore the measureless desire is directed." 
into light, and traced the ways in which it was satisfied, whether by speculation, labour or usury. I That is to say, he had discussed it as a rational pursuit, or rather, as Sombart himself also regards it, as an irrational pursuit rationally pursued. Thus the two criteria of rationality and the striving for gain, which Sombart is prone to suggest are confined to the modern age, were both known in ancient Greece.

Nor were they unknown in the Middle Ages. It may be wrong to follow Brentano in thinking that the exploitationcapitalism of Rome throughout the duration of the Pax Romana, and the fact that the Punic Wars were first and foremost trade wars, have any direct connexion with the capitalism of modern times. ${ }^{2}$ But it is difficult not to admit that modern capitalism was emerging in Ravenna (which, under Roman Emperors or Gothic Kings was the chief entrepôt for the lucrative trade of the West with Byzantium) as early as the fifth century. 3 Commercial enterprise on a large scale, a whole-hearted and rational organisation of the pursuit of gain, and the rise to importance of fluid capital capable of being applied wherever the chances of profit were most tempting, were phenomena of very early occurrence in the eastern Mediterranean. The rise of the Saracen power in the Mediterranean acted as a check on this capitalistic development. But it was a check caused by external circumstances, not by a psychological change. There was no loss of the capitalist spirit in Italy; it was not from lack of will but from lack of power that commerce declined in the Mediterranean, just as it was not from love of a self-sufficing economy that the agrarian estates of the greater part of Europe came to adopt the policy of subsistence farming, but because of decline of town life and the dislocation of trade caused by the destructive invasions of the barbarians, and later of the Saracens and Norsemen. As soon as conditions began to be in any way favourable, the commercial spirit emerged in the operations

I Aristotle, The Politics, Book I, Chapters ix to xi.

2 Brentano, Die Anfaenge des modernen Kapitalismus, pp. $18 \mathrm{ff}$.

3 Ibid. pp. 89-90. 
of the merchants of the Italian towns such as Amalf, Venice, Genoa, Pisa and, later, Florence. It was the same further north, where in Flanders, Artois and Brabant a long-distance trade grew up, at first chiefly in fish and salt and Baltic products, and later in the cloth and metal goods of the Belgian industrial hinterland. Of course, trade between these two centres soon sprang up, raising to prosperity convenient centres along the chief trade routes-in Champagne, at Geneva and Lyons; at Frankfurt, Strassburg, Ulm, Nuremberg, Cologne and Aix-laChapelle-and peopling them with capitalistic merchants.

Sombart has been tempted to deny that the activities of these centres were capitalistic. But to do so, he appears to have introduced another criterion of capitalistic development: the amount of trade carried on as compared with the present day. $\mathrm{He}$ has collected a great deal of information with the object of proving that no large-scale economic activity was carried on in the Middle Ages, that even commerce was only conducted on a scale comparable with small handicraft industry. He has controverted very strongly Ehrenberg's dictum that commerce must of its very nature be carried on capitalistically. He has based his arguments on these grounds: firstly, on the large number of merchants who were engaged in carrying on a very limited trade; secondly, on the small size of the capitals subscribed by merchants going into partnership (of the first fifty partnerships registered in Genoa in I I56 the average capital subscribed was only about 150 lire); thirdly, on the small amounts of property owned by the inhabitants of cities like Basel and Augsburg in the fifteenth century as revealed by their tax returns; and, fourthly, on the small size of the ships generally employed and the small value of their cargoes. He has pointed out, for instance, that seven Spanish ships carrying iron, fruit and wool, which were captured by English warships in 1470, varied from 40 to 120 tons and were worth, cargo included, from $£ 70$ to $£, 180$ in sterling money of the time.

He suggests that with regard to commerce, "everywhere the same picture is offered us: apart from a few greater and often 
not professional merchants, only a swarm of small and insignificant traders". And so the merchant was entirely of a piece with the petty town workman; his whole outlook on life was the same; he was without capitalistic motives, he was content to receive as the reward of his labours what would ensure him the common sort of existence of his social class; he was without the desire to strive after greater and greater gain which distinguishes the modern entrepreneur. ${ }^{\mathrm{I}}$

Sombart is right on many points. It does not do to pretend that medieval commerce was on a scale comparable with that of the present day. Conditions of transport and the comparative smallness of the population alone would have prevented it. But this means only that technical conditions were not suitable for such a capitalist expansion as we have known in recent times, and on the same grounds one must deny the existence of capitalistic activity before the railway age. The total amount of merchandise carried over the St Gotthard each year at the end of the Middle Ages would only fill two goods trains passing through the tunnel to-day, and the tonnage compared with what passes to-day would be in the proportion of about $I: 237$. But the rise in the amount of traffic carried over the St Gotthard by $1831-3$ was only in the proportion of $\mathbf{I}: 3 \cdot 2$, which is no very enormous growth. ${ }^{2}$ And to argue in this manner is, as Pirenne said, like arguing that the Middle Ages knew no urban life, because they knew no large cities like those of the present day. 3

In any case, Sombart's figures do not tell the whole story. Sombart himself has collected a great deal of information about the extent of inter-local commerce in medieval Europe; he has an astonishingly long catalogue of objects found in trade circulation. 4 This trade was not carried on without the motive of large gains-the trader who carried on his business solely by

I Sombart, op. cit., especially I, Kap. I8.

2 J. Kulischer, Allgemeine Wirtschaftsgeschichte, I, p. 267.

3 Pirenne, Les périodes de l'histoire sociale du capitalisme, p. 9.

4 Sombart, op. cit. I, pp. 233 ff. 
tradition was not likely to be found seeking distant markets or sources of supply. And Sombart's "wimmelnde Schar kleiner und kleinster Haendler" was not so universal as he suggests. The petty draper who corresponded to the ubiquitous German Gewandschneider was rare in the towns of Flanders. In his place large merchants would be found. They must ordinarily have bought 400 or 500 pieces of fine serge a year, besides their purchases of cloth as distinct from worsteds. I At Bruges a regulation was framed in I3I4, on grounds which are easily understood when we consider the difficulties of securing the necessary labour for the manufacture of large quantities of fine fabrics, by which a maximum annual sale of such a large quantity as 800 pieces of "Ghistelles" cloth was fixed for each merchant. ${ }^{2}$

The rebuilding, in the course of the thirteenth century, of the new Cloth Hall at Ypres, with its quarter-mile long façade, owing to the previous hall having been too small for the transaction of business, suggests that the trade of this town at any rate was on a bigger scale than Sombart would probably like to allow.

Nor do Sombart's arguments from the small amounts of capital subscribed to the partnership agreements he has inspected bear as much weight as appears at first sight. Each of the partners was in all probability interested in a large number of such partnerships at once. He has himself pointed out that the two largest partnership contracts registered in the Town Book at Luebeck in the fourteenth and fifteenth centuries were contracts for the amount of 3200 and 4600 luebecker marks (or about $\delta_{1600}$ and $\delta_{2300}$ in present-day metallic value and much more in commodity value) between the same two people. 3 The conditions of commerce were such that the merchants used to divide their capitals and employ them in separate enterprises for the sake of safety. Also, commerce was then as one might say in the "tramp" rather than the "liner" stage of capitalist

I H. Pirenne, Les périodes de l'histoire sociale du capitalisme, p. $3 \mathrm{r}, \mathrm{n}$.

2 H. Pirenne, Histoire de Belgique, II, p. 68, n. 2.

3 Sombart, op. cit. I, p. 286. 
development; the long-distance business which was carried on was not as a rule so standardised that merchants made their fortunes out of one trade connexion. They varied their activities, and subscribed separately towards each separate venture instead of subscribing a fixed capital to establish a permanent business. In this way the figures of the capitals subscribed were kept lower than they would have been had they been subscribed once and for all to establish permanent activities. But owing to the slowness of transport and the consequently sluggish turnover, and the size of the risks, the rate of profit on these mediocre capitals must have been considerable, and for that reason the capital subscribed must have had much significance.

We also meet examples of a commerce which, if not large as compared with modern times, was yet far removed from petty commerce of a handicraft type. The export of wool from England in 1273 (apparently to the north of France and Flanders) amounted to 35,000 sacks, valued at $£ 1,000,000$ in modern money. The firm of Scotti of Piacenza alone exported wool to the value of 21,400 marks or $£ 62,500-64,000$ in this year. A few of the townspeople of Arras had acquired sufficiently large fortunes to be able to provide the Count of Guines with 20,000 livres with which to pay his ransom in 1254. In 1339 three merchants of Malines lent Edward III of England 54,000 florins, which would be about $£ 28,000$ in present-day metallic value. In 1320 the commune of Florence owed 40,000 gold florins (about $£ 20,000$ ) to the firm of Acciajuoli and four other partners for grain delivered. In 1429 Giovanni Medici left to his two sons property worth 179,000 gold florins, of which r 40,000 gold florins (or about $£ 70,000$ ) was business capital. Firms carried on operations all over Europe. In the fourteenth century the firm of Peruzzi had 16 branches and over 150 factors in different parts; the Acciajuoli had in 134I altogether $4 \mathrm{I}$ agents- 2 in Pisa, 6 in Genoa, 1 in Paris, 2 in Bruges, 2 in London, 3 in Avignon, 5 in Naples, 2 in Tunis, 2 in Chiarezza (Morea), 3 in Rodi, 3 in Famagusta, and 3 in Sicily-who carried on commercial operations as well as financial transactions. 
Even the ships were not always as small as the Spanish ships which Sombart mentioned. Four Naus ${ }^{I}$ with an average carrying capacity of 9000 quintals or nearly 900 tons entered Barcelona harbour in 1498 , a size which was not exceeded before the nineteenth century. As the freights usually consisted of precious cargoes, their value was much greater than that of a similar weight of cargo to-day. In 1473 the Medici lost 30,000 gold florins $(£, 15,000)$ on one ship. A Genoese ship which was wrecked at the mouth of the Danube was worth about $£ 35,000$, and two ships captured by the Pisans in I 164 represented a value of more than $£_{100,000 .}{ }^{2}$

It might be argued, however, that the type of capitalism which is evident in these commercial transactions is not of the type of modern capitalism. Max Weber.confines his attentions, it is very true, to capitalism of the industrial type directed more by diligence than by speculation. But even this was to be found largely exercised before the Reformation could supply the Protestant Ethic. In Belgium, for instance, two very important industries were long established, working under capitalist direction for the export market. The brass industry of the valley of the Meuse and the cloth industry of the Flanders plain were very different from the small-scale town industries catering for a shut-in local market which Karl Buecher wished to universalise in his Evolution of Industry. The workmen were not in touch with the consumer; they came into contact with him only through the merchant brass-founder or the merchant draper who employed them. The Dinant kettles and Flemish cloths passed through many hands before they reached the ultimate consumer, and the intervention of a considerable capital was requisite to finance their sale. And so the direction of labour came to be in the hands of merchants who distributed the raw materials among the workmen, paid at piece rates for working

I A Nau was a heavy sailing ship with raised poop and forecastle, with at first one and later two triangular sails. It was similar in build to the northern Kogge.

${ }_{2}^{2}$ Pirenne, Les périodes del'histoire sociale du capitalisme, p. 33 ; Kulischer, op. cit. I, Pp. 264 ff. 
them into finished articles; who then sold the products, the manufacture of which they had at all stages directed. The workmen were not grouped together in factories as in modern times. The work was carried out in little workshops. ${ }^{\text {I }}$ And the men were not all employed directly by the capitalists who financed them. Master-craftsmen acted as sub-contractors, employing journeymen to make the goods required by the merchant-employers. But these differences in technical organisation were all that distinguished this order of industry from modern large-scale capitalist industry. There was a clear-cut distinction between merchant and manufacturer; the one was a capitalist, the other a wage-earner, and the capitalist made his profit as any modern industrialist-by buying and selling in the best market and by the rational organisation of labour. ${ }^{2}$

I Sombart has tried to prove the absence of capitalism within the medieval towns by pointing to the large number of handicraftsmen who lived within them. This he takes to be a proof of the small scale of their operations (op. cit. I, Pp. 265 ff.). The importance of this argument must be discounted very considerably. A large number of handworkers, and even their membership of a gild, does not prove the absence of capitalist industrial organisation. The important factor from this point of view is the equilibrium between the different classes of workmen. This is said to be typical of the towns of the Middle Ages, but it was entirely non-existent in the Flemish cloth-making cities, which had as specialised populations as any modern manufacturing cities or mining villages. It was simply by their large numbers as compared with the numbers of the members of other trades that the workers in capitalistically controlled export industries were distinguished from the independent craftsmen who produced for the town market. At the beginning of the fourteenth century there were 4000 weavers in Ghent-an enormous proportion for the total population could not have exceeded 50,000. The various clothworkers with their wives and children formed the great majority of the population of the Flemish towns. In Ypres, in 1431, when the cloth industry had long been in decay, it still employed $5 \mathrm{I}^{\circ} \mathrm{C}$ per cent. of the active population.

${ }^{2}$ Pirenne, Histoire de Belgique, I, II; Les anciennes démocraties des Pays-Bas; "The Place of the Netherlands in the Economic History of Medieval Europe", in The Economic History Review (January 1929). G. Espinas, "Jehan Boine-Broke, bourgeois et drapier douaisien", in Vierteljahrschrift fuer Sozial- und Wirtschaftsgeschichte, II (1904). 
In Florence the organisation of the woollen-cloth and silk industries was carried on under similar capitalistic control. Once again the raw materials and the finished products were drawn from and exported to distant and varied markets, which could not be reached without the intervention of much capital. There was an even more definitely capitalistic control of industry here than in Flanders. The preponderance of the woollen industry was fairly complete until the middle of the fifteenth century when the silk industry came to be more prominent. Although Sombart has shown that Villani's account of 100,000 pieces of cloth being manufactured in the city in 1308 is a picturesque exaggeration, as it was scarcely possible to secure enough wool to manufacture this amount, ${ }^{\mathrm{I}}$ the probable yearly production of about 15,000 to 20,000 pieces was nevertheless considerable, and individual undertakings of some magnitude were known. About forty workmen would be employed in one of medium size, twelve of them in the workshop of the entrepreneur, the rest as domestic workmen in their own homes, with an annual production of some seventy pieces of cloth. An undertaking of a larger order would make 200 pieces of cloth in the year, employing 100 workmen, thirty of them in the workshop of the entrepreneur. And in Florence, the owners of capital ensured that their ownership of capital should bring them full and undivided power of management. ${ }^{2}, 3$ It is difficult to think of a better example of ceaseless striving after gain by means of the

I Sombart, op. cit. I, p. 281. The substantial accuracy of Villani's information has, however, lately been re-affirmed. See a review of an article by A. Sapori on the credibility of the information given by medieval chroniclers, in Annales de l'histoire économique et sociale, April 15th, 1930, pp. 308-9.

2 Cf. Doren's verdict, quoted in Tawney, Religion and the Rise of Capitalism, p. 292: “. . . es gibt wohl keine Periode in der Weltgeschichte, in der die natuerliche Uebermacht des Kapitals ueber die besitz- und kapitallose Handarbeit...bis in die entferntesten Folgen zur Geltung gebracht worden waere, als in der Bluetezeit der Florentiner Tuchindustrie".

3 Convenient short accounts of the Florentine wool industry are found in Kulischer, op. cit. I, pp. 218 ff.; M. V. Clarke, The Medieval City-State. 
rational organisation of (nominally free) labour ${ }^{\mathrm{I}}$ than was provided in fourteenth-century Florence.

Should the concept of capitalism, however, be confined to this? Does not capitalism consist in a fusion of a romantic and a rationalist tendency as well as in the purely rational pursuit of gain through industrial organisation? Sombart expressed this feeling very well when he wrote in the first edition of his Der moderne Kapitalismus that if he were pressed to give a definite birth-date for modern capitalism, he would choose A.D. I 202the year in which Leonardo Pisano's Liber Abbaci (the arithmetical treatise which first rendered exact calculation possible) appeared, and in which Venice began the attack on Constantinople which marked the beginning of the exploitation of the East by Western Europeans-especially by the Italian communes-and through which the large-scale accumulation of money began. ${ }^{2}$

Sombart has indicated here what seem to be very valuable considerations. The warfare of the period of the Crusades deserves some prominence in the history of capitalism. It is doubtful if one should dignify much of it with the name of warfare-piracy and brigandage would be more appropriatebut it is important in at least two respects. It was carried on as a commercial undertaking for plunder (Sombart's "one-sided trade"), and the equipment of a warlike band called for a large capital, larger than for any ordinary commercial or industrial undertaking of the time. Also the booty secured was one of the great sources of the early hoards of capital. Thus the pillaging of the Levant was of importance in the early history of capitalism.

The second consideration called forth by Sombart's statement is even more enlightening. The rise of financial science was a necessary condition of the growth of capitalism. It enlarged the institution of private property by mobilising all forms of capital and removing the obstacles which differences

I Which is Weber's conception of capitalism.

2 Sombart, op. cit. Ist ed. I, p. 392. 
of time and place might set in the way of its profitable employment. It allowed capital to become impersonal and abstract, a mere counter of general purchasing power, of general productive capacity. It enabled one to invest capital in an undertaking and withdraw and dispose of one's holding at will without withdrawing any of the equipment of the undertaking or interfering with the business in any way-the transfer being made in paper which represents a share in the undertaking. It is by attaining to impersonality and so to mobility that capital has gained in strength and security, and it has been the mathematician, the accountant, who has provided the rational basis for giving all forms of capital mobility. The great cause of the rise of rational capitalism was not Christian at all-it was a secular scientific development, taken over by Western Europeans from Muslim Arabs and Syrians.

It was not impossible to combine these romantic and rational capitalist tendencies. The history of the Italian communes is one continuous example of this being done. They turned the Crusades to their own commercial advantage. The desire for gain stimulated every action of the individual Venetian and his republic, and was rationally pursued. One is impressed, said Heyd, by "this practical sense which is at the bottom of all their acts". I

Colonial policy consisted simply of aggrandisement for commercial aims. Colonies would be let to private citizens for exploitation. We even find that a new capitalistic form of organisation-the Maona or permanent joint-stock companyarose in Genoa in 1347 out of an undertaking on the part of a number of individuals to seize the island of Chios, which was a valuable source of supply for alum, and afterwards to take over its administration. ${ }^{2}$ Thus there was a strong connexion between

I Heyd, Histoire du Commerce du Lévant, I, p. 270.

${ }^{2}$ Heyd, ibid., remains a first-rate authority for these developments. Interesting information may also be had from older works such as Wiszniewski, Banque de S. Georges à Gènes. Wiszniewski quotes an interesting comparison between Genoese and British commercial policy 
the rational and the purely acquisitive aspects of capitalism in the operations of these Italian cities.

It is very likely that both the rational and the more romantic aspects must be present for any real "capitalism" to emerge. I The crux of capitalism lies in the function of risk-bearing. Risks are increased that commercial activity may be increased, but narrowed down again by attempts at rational forecast of the probabilities and rational organisation to avoid loss. Speculation is not an antipathetic growth on true bourgeois capitalism, it is the central feature of capitalism. One might say quite truly that the essence of capitalism lies in rational speculation. Therefore one must admit that the capitalist spirit was not absent in the case of merchants like Godric of Finchale, who, born of poor parents towards the end of the eleventh century, set himself from the beginning to learn the secrets of successful trading, learnt with great success to carry on trade by transferring goods from a low-priced to a dear market, and increased the scale of his operations by re-investing his profits regularly. ${ }^{2}$ But Godric was surely only one of many who

from Cibrario: "Le commerce était donc l'âme de leur politique, comme il l'est de celle de la Grand-Bretagne, qui a aussi entouré le globe terrestre de stations maritimes, pendant que Napoléon distribuait des couronnes à ses maréchaux...". Sombart, op. cit. I, pp. 44I ff. contains useful information on the Genoese Maona.

I Sombart seems to come to much the same conclusion, and looks on capitalism as a combination of an irrational Erwerbsprinzip and a rational organisation of economic factors to serve this principle.

2 Pirenne, Les périodes de l'histoire sociale du capitalisme, pp. $19 \mathrm{ff}$; Les Villes du Moyen Age, pp. 10; ff.

It might be interesting to quote Pirenne's remarks (Périodes, loc. cit.): "Godric nous apparait, en effet, comme un calculateur, je dirai même comme un spéculateur. Il a le sentiment très juste de la pratique du commerce, sentiment qu'il est d'ailleurs fréquent de rencontrer chez les esprits sans culture. Il est enflammé de l'amour du gain et l'on reconnait nettement chez lui ce fameux spiritus capitalisticus dont on a voulu nous faire croire qu'il ne datait que de la Renaissance. Or voici qu'un marchand du $\mathrm{xI}^{\mathrm{e}}$ siècle, associé à des compagnons semblables à lui, combine ses achats, suppute ses benefices et, au lieu de se contenter de cacher au 
carried on the same sort of operations, whose names have not come down to us because they were not touched with grace, did not retire from business to live a hermit's life, and so did not secure a monkish biographer.

The same principle of economic rationalism was present in the financial operations which became more and more widespread as the Middle Ages advanced. The chief advances in the technique of finance were made by the Italians, but financial operations also developed largely independently of them in the north of Europe. I As early as the thirteenth century, as the result of tenures becoming absolutely free, real property was being actively exploited in the interest of commercial credit in the commercially well-developed regions of Champagne and Flanders; and those places where it was most commonly mortgaged were precisely those where economic well-being reigned more securely. ${ }^{2}$ In Italy the beginnings of banking go back to the same early date; it had become usual for depositors to place their capital in banks which paid a fixed rate of interest and promised to repay the principal either at a fixed date or after due notice of withdrawal. The needs of finance were so well studied here that the Florentine public debt funded in 1345 was not tampered with when revolutionary factions so often shook the town. The Florentines were astute enough to see that

fond d'un coffre l'argent qu'il a gagné, s'en sert pour alimenter ses affaires et les étendre...".

In his "Les Raisons intellectuelles d'une suprématie commerciale: La Hanse", in Annales de l'histoire économique et sociale, October 15th, 1930, F. Roerig insists that the chief reasons for the success of the Hansards were their rational methods of conducting affairs, and that progress in commercial methods since the thirteenth century has been merely quantitative. The piling up of important studies such as this seems definitely to cut the ground away from under Weber's feet. Cf. still another important article in the same journal for January 15th, 1929H. Pirenne, " $L$ 'instruction des marchands du moyen âge".

I Cf. the important work by G. Bigwood, Le régime juridique et économique du commerce de l'argent dans la Belgique du moyen-âge.

2 G. des Marez, La lettre de foire à Y pres, p. 52. 
the public credit must be kept inviolate. In Spain also, financial institutions early reached a high degree of importance. ${ }^{2}$

It was in financing trade by means of the bill of exchange that the greatest progress was made. Medieval transport facilities were so bad, and communications so unsafe, that the risks of trade were enormous--not the least being those of catering for markets months ahead on account of the slow circulation of goods. If there had been added to these hindrances the difficulty and the risk of transporting large quantities of specie in order that every commercial transaction might be carried through to its conclusion, long-distance commerce could never have survived. As late as 1585 a courier was paid ro francs for carrying a mere 720 francs from one town in Franche-Comté to another less than 20 miles away. It was explained in the account that one horse could not carry such a sum as well as the rider. As soon as the sum to be carried exceeded 1500 francs a waggon was necessary, together with an armed guard. It cost 55 francs and meant a three days' journey to transport 2200 francs less than 40 miles in this manner. 3 Some method of economising in the transfer of money had to be developed. This was the bill of exchange, at first employed as a fair letter which was settled by virement at the fair on which it was drawn, later by means of correspondents at fixed places. From about the end of the twelfth century the bill came to be employed all over Europe. 4

I G. Bousquet, "Internationalisme financier au xvi siècle", in $L a$ Revue de Paris, July ist, I923.

${ }^{2}$ A. P. Usher, "Deposit banking in Barcelona", in the Journal of Economic and Business History, November 1931.

3 L. Febvre, "Types économiques et sociaux du $\mathrm{xvI}^{\mathrm{e}}$ siècle"; in Revue des cours et conférences, December I 5 th, I92I, P. 58 .

4 On the development of the bill of exchange see Goldschmidt, Universalgeschichte des Handelsrechts: Huvelin, Essai historique sur le droit des marchés et des foires: "Travaux récents sur l'histoire de la lettre de change", in Annales de droit commercial, 1901: Mitchell, The Law Merchant: Des Marez, La Lettre de foire à Ypres: Holdsworth, History of English Law, vill: Vigne, La banque de Lyon: Peruzzi, Storia del commercio e dei banchieri di Firenze: Ehrenberg, Capital and Finance in the 
Those who developed it most were the Florentines. The woollen-cloth and silk industries of Florence drew their raw materials from and exported finished goods to a wide area. The town was in intimate trade relations with all Europe and a large part of Asia Minor. We can glean information about their manifold trade activities from two treatises on the practice of commerce, written by Florentines in the fourteenth and fifteenth centuries. I In these books the commercial possibilities of trade with Constantinople, Trebizond, Armenia, Romania, many places in Asia Minor, Barbary, Sicily, Sardinia, Spain, the cities of Italy, Burgundy, the Champagne fairs, Paris, Flanders, especially Bruges, Brabant, Antwerp, England, especially London, and Gascony were explored and the usual methods of trading with them were indicated.

The extensiveness of the Florentines' commercial relations as established by this list made it almost inevitable that the development of the bill of exchange should have been in their hands. They possessed an adequate number of commercial agents in different commercial centres to act as correspondents, and sufficient foreign balances with which to carry on operations; they also possessed a strong flair for finance. ${ }^{2}$ So they devoted

Age of the Renaissance: Bourquelot, Etudes sur les foires de Champagne: A. E. Sayous, "Les transformations des méthodes commerciales dans l'Italie médiévale", in Annales de l'histoire économique et sociale, April I 5 th, 1929, pp. I6I ff.; this contains an excellent bibliography useful also for general Italian economic history.

I Pegolotti, Practica della mercatura (1335-43); Uzzano, Practica della mercatura (1442). These are published as volumes III and IV of Pagnini, Della decima...dal Comune di Firenze; della moneta e della mercatura de' Fiorentini.

${ }_{2}$ This is proved by the greater flexibility which the bill received in their hands. It was not till the sixteenth century that the bill of exchange became a negotiable instrument in Europe generally. The "or bearer" formula only came into extensive use in Antwerp about 1560, and despite the formula it was usual to transmit bearer bills and bonds with due formality before a notary. The town of Malines even clung obstinately to the old form and decided that the possessors of bearer bills had to justify possession. (Des Marez, La lettre de foire à Ypres, pp. 66-7; Goris, Les 
themselves to the development of foreign exchange transactions. These were the most promising speculative field of which the Florentine of the later Middle Ages knew. And his speculations were the result of rational forecasts, of an acute observation of economic trends. The Florentine did not, like some of his imitators, attempt to forecast the course of the exchanges by astrology. They moved in ways which were quite comprehensible to him; he had found out the principles which governed them and was concerned with turning his knowledge, his wit and his skill to the best advantage. The rational capitalist spirit showed in all his activities. In his Practica della mercatura, Uzzano showed that a knowledge of the exchanges and of exchange transactions. were requisite for a merchant to be successful, which he assumed to be his one aim in life.

The proper management of exchange transactions, he said, lay in never owing in a currency which was appreciating in value. Therefore one must take into account the factors which might cause an appreciation. These might be the demand for money caused by the holding of a fair, by the departure of a fleet, the establishment of a "corner" or monopoly of some sort, or by large payments having to be made to an army, lords or commune. One must beware of buying dear bills; instead one should procure credit before the market rises, for anticipation is the prime requisite of a merchant. One must never hold on too long, but get clear before the market gives way, for it must be remembered that demand induces a supply- "for it must be taken into consideration that after dearness comes plenty".

He pointed out that money was normally dear in Florence from September to January, because payments had to be made colonies marchandes méridionales à Anvers, p. Irr.) But the use of the "or bearer" formula had been very early adopted in Italy. (Mitchell, The Law Merchant, p. 34.) This shows that the Italians were able to visualise abstract values much better than the Flemings - to see that the bill which A. drew on $B$. had no necessary connexion with the bales of cloth with which he had supplied B. Scientific finance, then, came much easier to the Italian than to the Fleming. 
to the peasants for the harvest. At Pisa it was dear every year from Easter to Whitsuntide on account of the soldiers receiving their pay at this time, and also from June to September because there was a drain to Venice caused by the shipping of the galleys to the Levant during these months. At Genoa money was dear at Easter and again in July because the galleys left for the Levant on July 15 th. In Vicuna and Montpellier it was dear at the times of the fairs, of which there were five every year, and also from the middle of June to the middle of July as much money was invested in grain, wool, etc., at this time. He gave similar information for Barcelona, Bruges, Paris, Venice, Bologna, Naples-even remembering to warn the speculator that in Venice gold appreciated more rapidly than silver, as it was in greater demand for shipping to the East. ${ }^{I}$

By what criterion can it be denied that Uzzano and those who followed his teaching had the capitalistic spirit? They set out to satisfy their desire for gain by means of speculation resting on a sound rational basis - and by so doing they performed services which increased the international importance of capital and hastened the rise of a completely capitalist civilisation. Their activity gradually spread through Europe, and by the sixteenth century finance was a completely specialised capitalist business. A proposal to prohibit trading in any commodity to those not apprenticed to that particular trade which was made at Lyons towards the end of the sixteenth century, was met with the argument that it was impossible to suit the restriction to those who did business "with an inkpot and balance sheet, without art, trade, booth, shop, workshop, stuff or merchandise" - to those who dealt in the immaterial yet chief commodity of Lyons, finance. ${ }^{2}$ At the Spanish fairs there were bankers who opened deposit accounts for their customers and granted overdrafts - the customers made all their payments by bills on their bankers, who neutralised their debits and credits by simple book-keeping transactions. Though undeveloped it

I Uzzano, loc. cit. pp. 153 ff.

2 Hauser, Les débuts du capitalisme, p. 217. 
was essentially already our modern system of cheques and clearing-houses. ${ }^{I}$

The development of insurance transactions was also far advanced before the end of the Middle Ages, which is another example of the rational organisation of the risk-bearing function which is fundamental to capitalist development. ${ }^{2}$

It would take too long to follow out the actual history of these various medieval capitalistic developments. It should be noted that the Catholic Church was itself largely responsible for some of them. The industrial and agricultural activities of the Cistercians in the end necessitated complex capitalistic arrangements for the sale of wool. The abbeys used to act as mortgage banks. ${ }^{3}$ And the Roman curia was an enormous financial organisation collecting taxation from all parts of the Christian world, served by a galaxy of important banks and money-changers. These campsores Romanam curiam sequentes must not be forgotten as weighty influences on the history of capitalism.

One other influence on the rise of capitalism already in existence in the Middle Ages deserves some comment. Reference has already been made to the suggestion that the appearance of Pisano's Liber Abbaci might be considered a landmark in the history of capitalism. It is to scientific book-keeping much more

I Huvelin, Droit des marchés et des foires, pp. 569, 571; Usher, loc. cit.

2 See on the various insurance topics, Goldschmidt; Mitchell; Sombart, op. cit.; also Goris, op. cit. pp. $178 \mathrm{ff}$., $385 \mathrm{ff}$., $38 \mathrm{Iff}$. (on forward exchange speculations), 425 ff. (on bets on the sex of unborn infants and other practices leading to genuine insurance practices); Sayous, "Spéculation dans les Pays Bas" (Journal des Économistes, I90I, XIvII); Pardessus, Us et coutumes de la mer; Hoover, "The Sea Loan at Genoa", in Quarterly Journal of Economics, $\mathrm{xL}$; and as an example of the stage reached by juristic writers on insurance by the beginning of the seventeenth century, Scaccia, De Commerciis. See also A. E. Sayous, "Les transformations des méthodes commerciales dans l'Italie médiévale", in Annales de l'histoire économique et sociale, April I 5 th, 1929.

3 See for example, Génestal and Allix, "Les opérations financières de l'abbaye de Troarn", in Vierteljahrschrift fuer Sozial- und Wirtschaftsgeschichte, 1904. 
than to the ethic of any religious system that we owe the rational methodising of business life. Systematic organisation is one of the most powerful agents of economic progress, and this holds good perhaps more of systematic book-keeping than of any other form. As Sombart has said:

Organization and clearness increases the desire to save and to acquire. A man who manages badly finds himself in a fog; he does not like to correlate the entries to see what he owes. On the other hand, nothing can be more acceptable to a good manager, than to examine every day the amounts of his growing fortune. Even a loss, if it annoys and surprises him, does not perturb him, for he knows at once what profits he has gained to set on the other side. ${ }^{\mathrm{I}}$

Is it not likely that this has had a greater effect than the doctrine of the "calling", which must always remain a little alien to business thoughts?

The organisation of business on the basis of double-entry book-keeping must have had an overwhelming importance in the development of a capitalistic order of society:

Capitalism without double-entry book-keeping is simply inconceivable. They hold together as form and matter. And one may indeed doubt whether capitalism has procured in double-entry bookkeeping a tool which activates its forces, or whether double-entry book-keeping has first given rise to capitalism out of its own (i.e. rational and systematic) spirit. ${ }^{2}$

Until the emergence of systematic book-keeping there naturally remained something of the old "subsistence" ideal of life of the canonists, the ideal of all business activity being carried on primarily to provide subsistence for the merchant and for those with whom he dealt-what might be called a "commodity" conception of business. But the man who devotes himself to transactions on a book-keeping basis has only one aim-the increase of values comprehended only quantitatively. He does not consider mainly corn or wool or cotton or cloth or the cargoes of ships, or tea or pepper. These (the true

I Sombart, op. cit. II, p. I 18.

${ }^{2}$ Sombart, loc. cit. 
realities of commerce) become mere shadows, they become unreal and the apparent reality seems to lie in book-keeping ciphers. ${ }^{I}$ All that the merchant who employs systematic bookkeeping sees are money values which increase or grow less.

It was only by means of the clarifying process brought in by systematic book-keeping that the various elements of a man's property came to be distinguished and the amassing of wealth was seen to consist in the alterations of these elements one to another - the very conception of capital as "lucrative possessions" practically depends on the analysis of scientific accounting:

One can define capital straight away as the wealth set aside for gain comprehended by means of double-entry book-keeping. ${ }^{2}$

The entry of systematic book-keeping into business not only made clearer the acquisitive ends of commerce-the aim of amassing rather than of procuring the satisfaction of one's wants by means of the exercise of a "natural propensity to barter and truck". 3 It also provided the rational basis on which

I H.M. Tomlinson expresses this very well in his novel of the runaway shipping clerk, Gallions Reach: "There is a region of grey limestone and glass, horizontally stratified into floors, intersected by narrow ravines called avenues, and honeycombed by shipping and commercial offices, which lies between Fenchurch and Leadenhall Streets. Billiter Avenue is one of its intersecting clefts... The wealth of the cave of Sinbad, compared with that of most of the offices in this canton of the city, would have seemed but a careless disposal of the superfluous, yet within the guarded recesses of the cliffs of Billiter Avenue no treasure is ever visible. It may be viewed at all only by confidential initiates, and even they cannot see it except as symbols in ledgers, bills of lading, bank drafts, warrants, indents, manifests, and in other forms designed to puzzle moths and official liquidators in their work of corruption". And again: "They were but names and markets to Colet. They were good names, though: mace, turmeric, myrobalans, cinnamon, benzoin, lac, gambir, annatto".

2 Sombart, op. cit. II, p. r 20.

3 I have said "made clearer", and not "create". It is doubfful if the acquisitive spirit was a secondary growth. It is much more of a primary factor than Adam Smith's so-called bartering propensity, which is simply a rationalisation of it. But it was overlaid by mercantile traditionalism which systematic book-keeping swept away. 
this acquisition could be carried on; it provided the basis for the continued rational pursuit of profit. Without a proper system of book-keeping profit could only be sporadically pursued, as opportunity offered. Until the science had been perfected there was no continuous systematic utilisation of capital, and no widespread diffusion of forms of organisation having for their object the profitable employment of definite capitals.

The use of exact accounts made it possible not only to know at any given time exactly how a business stood, but also to employ rational plans for extensive future operations:

The importance of book-keeping lies not only in the study of the past activities of an enterprise, but also in the indications which it furnishes for future direction. From the observation and study of events that are over it provides the possibility of forejudging future activity and finding sure bases for reasoning out the actions to come. ${ }^{\text {I }}$

It is so difficult to conceive of economic activity to-day not carried on with a book-keeping basis that we take its existence for granted, and it is hard to imagine what a revolution the introduction of scientific book-keeping methods must have caused. Yet nowhere has the rational element entered more strongly into economic activity than through accountancy-it is a necessary condition of the separation of the firm from the individuals of which it consists and therefore of the growth of large joint-stock businesses-and the slow spread of scientific book-keeping was one of the chief causes of the persistence of traditional and unbusinesslike methods of ordering affairs throughout the Middle Ages. An adequate book-keeping system is one of the cultural conditions necessary for the emergence of capitalism. It is a purely secular influence, and it was not absent from the Middle Ages. Double-entry was practised in Italy from the second half of the fourteenth century, though

I Gomberg; quoted by Sombart, op. cit. II, p. I2I. Most of the ideas which I have expressed here on the subject of the importance of bookkeeping I found in Sombart, op. cit. II, Pp. $118 \mathrm{ff}$. 
the yearly balance did not come in before the seventeenth century. Its rapid extension throughout Europe after the middle of the sixteenth century-following its introduction into Flanders by Ympym in 1543-was no doubt of great moment in the spread of economic activity and the spirit of capitalism. That the countries in which the science of book-keeping made the most progress were always those in which most economic progress was being made can no doubt best be explained as a mixture of cause and effect. But working on the same lines as Weber, it would be very easy to substitute systematic books for the Protestant Ethic as the origin of the capitalist spirit. There is no doubt that reliance on good books meant more than reliance on the Good Book. And there is still less doubt that the rise of the capitalist spirit is the same as the rise of economic rationalism-something which took place independently of Church teaching, on the basis of commercial experience. The great cause of the rise of the spirit of capitalism has been capitalism itself; and it has been conditioned by general cultural conditions, more particularly by developments in business technique, and by governmental and legal institutions affecting commerce. 


\section{Chapter III}

\section{THE RENAISSANCE STATE}

The great influence which moulded the history of capitalistic endeavour was the escape from medievalism. There had been a partial escape before the end of the Middle Ages, both in fact and in idea. The communalistic institutions of feudalism were absent from the trading towns. They were in process of being removed from still wider areas. In the world of ideas there was a steady inclination of the Church to be more and more favourable to the business man. The doctrine of the "Just Price" had been shorn of its terrors for the speculative merchant by St Antonino of Florence (1388-1455) and Gabriel Biel of Tuebingen (c. 1425-1495). Antonino had said that no injustice was done by deviating from the just price by the free consent of both parties to a contract, as no injustice was done to either so long as he did not consent through prodigality or from necessity, and also that it was probable that when buyer and seller contracted freely the price agreed upon would not be very far from perfect justice. ${ }^{r}$ Biel, while seeming to retain it, completely exploded the conception of the objectively controlled "Just Price" and as early as the fifteenth century reached the central truth that exchange is performed on the basis of differing subjective (use or exchange) values. ${ }^{2}$

The great influence which was responsible for the recoil of medievalism was, however, the rise of the Renaissance state and the philosophy on which its activities were based. The

I Antonino, Summa Theologica, 2, tit. i, cap. I6.

2 Biel, Sententiae, Iv, Dist. I5, qu. xii, para. S: "Nam emens desiderans mercem, nisi speraret maius commodum ex merce, quam ex pecunia quam tradit, non emeret, nec vendens venderet, nisi speraret lucrum ex precio". (For the buyer who desires a ware would not buy, unless he hoped for greater satisfaction from the ware than from the money he paid over; nor would the seller sell, unless he hoped for a profit from the price.) 
modern state was the enemy of internal privileges. It was the enemy of the old cosmopolitan ideal of a universal monarchy, and was prepared to fight national wars in favour of the principle of nationality. For these it relied on professional soldiers. It no longer required the old feudal levies, but money to pay its armies. Pecunia nervi belli! Thus it was the enemy of the old-fashioned feudalism with its inelastic taxation systems; and was usually unfavourable to common lands because these are not so efficiently cultivated as individual property. It placed in the forefront the ideal of economic progress in order that the state might be strong. ${ }^{\mathrm{I}}$

The philosophy of the new state was codified and expounded by Machiavelli (1469-1 527). It was Machiavelli who first stressed the necessity of realism, who pointed out that "he who does not take notice of what is done and only concerns himself with what ought to be done, learns sooner to ruin than to preserve himself". 2 "Let us give thanks to Machiavelli", wrote Bacon, "and writers of this sort, who openly and without dissimulation reveal what men are accustomed to do, not what they ought to do."3

It is, then, a very one-sided analysis of the problem of the rise or spread of the capitalist spirit which leaves Machiavelli and such purely secular thinkers out of account. The spirit of ambitious rivalry which the following of Machiavellian precept fostered amongst the crowned heads of Europe could hardly have been without its counterpart in the commercial world, and the outlook which Machiavelli advised a prince to adopt was applicable also to merchants. What Brentano has called the "pagan" emancipation from traditionalism of the school of Machiavelli worked in the economic sphere as well as in the

1 Cf. L. Brentano, Konkrete Grundbedingungen der Volkswirtschaft, pp. 3-4.

2 Machiavelli, Il Principe, c. I5 (quoted by Brentano, "Entwickelung der Wertlehre", loc. cit. p. 363).

3 Bacon, De augmentatione scientiae, VII, 2 (quoted by Brentano, loc. cit.). 
sphere of statecraft. What is even more important, Machiavelli believed in the prevalence of the "Economic Man" who "forgives the death of his father sooner than the loss of his property". ' He therefore advised a prince to take account of this fact in his relations with his subjects, to remember that "in general men are ungrateful, inconstant, hypocritical, fearful of danger and covetous of gain". The chief errors he could commit would be infringing their property rights or debauching their wives. The wise prince would indeed do just the reverse, and

Ought to encourage his citizens to be able peaceably to exercise their employment, in merchandise, agriculture and every occupation, in order that one should not abstain from improving his possessions for fear they should be taken from him nor another from opening up trade for fear of taxes....

That is to say Machiavelli formulated the principle of "Pauvre royaume, pauvre roi", and advocated that state policy should be based on the recognition and the encouragement of a capitalistic spirit amongst the subjects for the benefit of all concerned. ${ }^{2}$

The new states, however, did not proceed to grant immediate freedom to all forms and manifestations of capitalistic enterprise. It was believed that these should be stringently controlled by the central government. The conceptions of the new philosophies, fitting in well with the pretensions of absolute or would-be absolute monarchs, subordinated all individual interests to the presumed interests of the state. Individuals were not to be allowed to prosper solely on their own account, and there were many avenues to prosperity of which the state would not approve, believing that they conferred no public benefits. 3

Yet it must be emphasised that the rise of the Renaissance

I Brentano, Die Anfaenge des modernen Kapitalismus, p. 122.

2 Machiavelli, Il Principe, cc. 17, 21 .

3 Cf. Brentano, Konkrete Grundbedingungen der Volkswirtschaft, pp. 4-5. 
state was an individualistic development, and its theoretical basis was finally consolidated by the individualistic philosophy of Hobbes. According to the jurisprudence of Grotius, no man had sufficient freedom of contract to grant away his freedom. But according to the Hobbist jurisprudence, in every country all men had contracted themselves into slavery to the Great Leviathan. Man was the measure of all things, and the object of every man's voluntary acts was "some Good to himselfe". Amongst these voluntary acts had been the Great Contract to escape from the uncertainties of the state of nature. The contract of society brought obligations, but as "nothing is more easily broken than a man's word", the fulfilment of the obligations could only be secured by fear of the consequences of a breach. Bees and ants might be able to live in society without any coercive power, but not men; for among ants and bees private and common good were the same, but the spirit of emulation in man ensured a general divergence of public and private interests in human society. As the first requisite of civilised life was the maintenance of the state, all private interests had therefore to come under strict control. It was from a purely individualistic premiss that Hobbes drew his conclusions, opposed as they were to the toleration of individualistic practice.

As a result of the acceptance of the Hobbist doctrine, the most thorough-going individualist was inclined to regard individualism in practice only as a disruptive force. To secure free recognition individualism had to struggle both against itself and against the remnants of another doctrine descended from the Middle Ages. Free action according to the promptings of the capitalist spirit was forbidden by the anarchy to which complete individualism must lead. Yet the Hobbist type of magnification of the functions of the state rested on a sort of philosophical, or perhaps one should say on a moral individualism, and a way of escape from the contrast between Hobbist individualism and Hobbist authoritarianism might be found. If it could be shown that the assumption of a general antithesis 
between private good and common security was unsound, the theory would then be used in support of freedom of enterprise. Hobbism was a type of Utilitarian doctrine, but it differed from the Benthamite doctrine as to the conditions under which it believed that the greatest good of the greatest number was secured. It advocated regulation instead of freedom, but it would require no change of essential doctrine to make it advocate the reverse.

In formulating this doctrine Hobbes had only clarified the ideas of many who had preceded him. Hobbist philosophyleaving aside the inessential matter of the social contract, which had no practical significance- was the principle behind the statecraft of the Renaissance and the seventeenth, even the eighteenth, centuries. From the economic point of view it was mercantilism. But the doctrines of mercantilism did not remain unchanged.

With the transition from medieval to modern times, many of the obstacles which town gild monopolies had placed in the way of trade expansion were removed. When Charles $\mathrm{V}$ made the rising in Ghent in 1540 an excuse for abolishing the privileges of its misteries, he brought a new prosperity to the town. A mémoire written on the revolt foresaw that this would be the result. . Ten years earlier the English Parliament had intervened to prevent the gilds abusing their powers by hindering the admission of apprentices or new masters. ${ }^{2}$ It was becoming recognised that gild control of industry without safeguards was detrimental to the country's interests. But the tendency was simply to substitute a national for a local form of regulation. As a witness to this tendency in England (to which country I shall pay most attention) the whole series of Weavers' Acts, Apprentices' Acts and similar provisions carried through Parliament might be cited.

A very good idea of the extent to which state interference in

${ } \mathrm{H}$. Pirenne, Histoire sociale du capitalisme, p. 38 , n.; Les anciennes démocraties des Pays-Bas, pp. 269-70; Histoire de Belgique, III, p. I28.

222 Henry VIII, c. iv (I530-I). 
economic affairs had been carried, and of the extent to which it was taken for 'granted, may be gleaned from a project which was made to James I for raising revenue by the sale of pardons for offences against the penal laws. A list of forty-eight offences was given, which were apparently so heinous that it was not contemplated giving pardons for them. Twenty-eight of these were for offences against commercial regulations. ${ }^{\text {I }}$ Yet the first offence for which it was suggested pardons shoula be sold was the "saying and hearing of masse".

The degree of interference by the state in commercial affairs which was considered proper, was, it may be seen, very con-

r Brit. Mus. Cott. MSS., Titus, V, pencil folio 395. The commercial offences which were not to be pardoned were: "(2) Forstalling, regrating and ingrossing of Corne and other victuall; (3) Inclosures; (4) All offences against the Statutes of Draperie; (5) Using of trades to wch the partie was not Aprentice; (7) Exchange of money for gaine within the land; (8) The offences of Innkeepers in selling of Oates and horse bread at an higher price then is limitted; (9) Abuses in Alehouse keepers; (I0) Offences comitted by tavern keepers in selling of wine to be drunk in their houses and at prizes not warrantable; (14) Regrating of wolles and yarne, \&c.; (15) Transporting of Coin and Bullion; (16) Offences in not observing the assize of fewell, the assize of bread, the assize of ales, \&c.; (17) Transporting of leather, corne and other commodities prohibited to be transported; (18) Working upon hollidaies; (19) Not keeping of Mares for breed in Parkes; (20) Not weaning of Calves; (2I) Not mainteining houses of husbandrie; (25) Not loneing 4 acres of land to cottages newlie built; (27) Sowing of hemp and woade (i.e. neglect of this); (29) Offences in dressing and tanning of leather; (38) Trading in forreine Bottomes; (39) Importacion of Comodities prohibited; (40) Merchant strangers to sell by retaile; (4I) Merchant strangers to sell within 8 monethes; (42) Denizens selling to England not for readie monie; (43) Merchant strangers limitted how to imploy their money; (46) wages of Boatmen and the like; (48) Bruers for bruing beere of other prises then 8 . or 4 .". It appears as though commercial liberty was to be granted less readily than liberty in practically any other direction. The commercial offence of "forestalling" was so perennial a nuisance that it used as a matter of course to have proclamations aimed against it added to any other sort of government proclamation which was made. (See e.g. Steele, Tudor and Stuart Proclamations, No. 113). It continued to be proclaimed illegal at any rate as late as 1709 (Ibid. No. 4472). 
siderable. It was thought that only by the most stringent control could the stability of the state be assured. Unemployment in the clothing trade was a social evil liable to cause unrest, and at a time when the trade with the continent was interrupted the Privy Council might intervene and command the Merchant Adventurers to buy as many cloths as they were accustomed to do and the clothiers to make and bring to market their usual output. ${ }^{\mathrm{r}}$

The same considerations of state were responsible for the general government attitude towards the movement for enclosing the countryside and increasing the size of farms. It was generally admitted that Kett's Rebellion and other similar political ferments which occurred in the sixteenth century were caused by the enclosures. Desire for a greater social control of the enclosure movement was therefore caused by the wish to preserve the state from anarchy. Attempts were made to cure sedition by removing its causes through the appointment of Commissions of Enclosures in 1548. These were to safeguard the existing political order from attack by removing discontent with the social order. The chief author of the commissions, John Hales, wrote to Protector Somerset to this effect:

...albeit these worldlings think that it shall be but a money matter, yet am I fully persuaded, and certainly do believe in your Grace's sayings, that, maugre the Devil, private profit, self-love, and such like the Devil's instruments, it shall go forward, and set such a stay in the body of the commonwealth, that all the members shall live in a due temperament and harmony without one having too much, and a great many nothing at all, as at this present it appeareth plainly they have.... ${ }^{2}$

The same object of statecraft was upheld by Bacon, and led

I See, e.g. the Privy Council Meeting of December 24th, 1586 (Acts of the Privy Council, N.S. xiv, pp. 272-4).

2 Quoted in P. F. Tytler, England under Edward VI and Mary, I, pp. II $5-16$. 
him, though philosophically an individualist, to suggest a similar policy. "Above all things", he wrote in his essay of Seditions and Troubles, "good policy is to be used that the treasure and monies in a state be not gathered into a few hands. For otherwise a state may have a great stock, and yet starve. And money is like muck, not good except it be spread. This is done chiefly by suppressing, or at least keeping a strait hand upon the devouring trades of usury, ingrossing great pasturages and the like".

Thus we see that the new individualism inherent in the nationalist philosophy of the Renaissance meant in practice as little freedom from governmental interference as in medieval times. It evolved a philosophy of stringent control of the economic life of the individual by the great Leviathan. Looking at the history of the mercantilist period it is, at first sight, difficult to perceive any signs of the individualism which is rightly regarded as characteristic of it.

In reality, however, free enterprise was winning the day. It may or may not be true that public and private interests are in general at variance. But the assumption that this was the case was not a rational assumption on the part of the mercantilists: it was purely a priori. It was an irrational element in the more rational philosophy which had come to dominate modern times, accepted with no more question than the theological elements of medieval philosophy. It gave way before greater rationalism. It did not give way before the other irrationality of accepting straight away the belief in an invisible hand which brought a necessary identification between every private and the public interest. There was no element of mysticism in the new doctrines. But it was seen that it was irrational for the state to pursue its policy of minute regulation, because observations of human behaviour had shown this policy to be unsuccessful in attaining its objects. It was noticed that the penalties imposed by government did not coerce the merchants into following the ways mapped out for them. "For tyme, the truest SchooleMistresse, hath taught all Ages", wrote William Sanderson, 
"that noe penalties nor policie, could yet interpose between ye Merchant $\&$ his profitt." I

As one example of this growth of realism may be mentioned the decline of the "bullionist" period of mercantilist thought. It was seen that the laws against the export of bullion could not be enforced, and in recognising this fact mercantilism passed to a more liberal phase, in which a general policy of encouraging exports and discouraging imports to secure a "favourable balance of trade" was substituted for a surveillance of particular bargains.

John Hales had, as early as the middle of the sixteenth century, pleaded for a policy on the part of the government which should recognise the force of private interest, instead of irrationally persuading itself that private interest might be ignored, or turned aside by the mere passage of an Act of Parliament. When he wrote his Discourse of the Common Weal he made the Doctor discuss the possibility of restraining pasture farming by Act of Parliament in these words:

.... it weare hard to make a lawe therein, (so manie as have proffitt by that matter resistinge it). And if such a law weare made, yet men, studiing still there most proffit, would defraud the lawe by one meane or other. ${ }^{2}$

The policy of a commonwealth, he said, should not consist merely of multiplying restraints on the performance of actions deemed harmful, but should also furnish allures and rewards for performing actions deemed desirable. The efficient cause of the enclosures for pasture was avarice, but as avarice could not be eradicated from man, the only way to remedy the enclosures was to take away the occasion for them, which lay in "the

I University Library, Cambridge, MS. Gg. v. 18, p. 466: “ $A$ Treatise of State Merhant (sic) and of Merchandising State...by William Sanderson Gentleman, Cittizen, and Merchant of London". The MS. is dated $M D C$, but from internal evidence it can be shown to belong to the early part of the reign of Charles I.

${ }_{2}$ Discourse of the Common Weal, ed. Lamond, p. 50. 
exceadinge luker that they se growe by these inclosures more then by husbandrie". I To put a stop to enclosing it should be the policy of the state to equalise the profit which might be gained from corn-growing and from pasture. This should be done by removing the restrictions on the export of corn and transferring them to wool; by increasing the customs on wool; by taxing one acre of grass land as heavily as two acres of plough land. ${ }^{2}$ In this way Hales suggested that the government should turn man's natural self-interest to account, by furnishing him with better opportunities for profit in an occupation which was deemed serviceable to the state than in one deemed harmful. This suggestion brought with it the demand for greater freedom, and it marks a stage in the evolution of a liberal mercantilist doctrine.

It was a point of view which secured an almost universal adoption. If the school of Adam Smith believed that men sought only to advance their own private interests, the orthodox mercantilist school made the same assumption. The difference was that one school believed that private and public interests coincided; the other sought to make them coincide. Mercantilism was a policy of control by which governments sought to turn private interests to the service of the state, before the laissez-faire creed had gained sufficient support to make it generally believed that this was unnecessary. This more liberal side of mercantilist policy is found in the pamphlet by John Keymor which was for long attributed to Sir Walter Ralegh: the Observations on Trade and Commerce with the Hollander. It was one of the aims of this tract "to allure and encourage the people for their private gain, to be all workers and erecters of a Common-wealth".3 And it was upon this basis that the most characteristic feature of mercantilism rested. The encouragement of the exporter was the central working principle of

x Discourse of the Common Weal, p. 122.

2 Ibid. passim, especially the Second Dialogue.

3 Published in Sir Walter Ralegh's Remains, p. 204, in the edition of I66r. 
mercantilism-which John Hales again expressed very concisely:

And now, because we are entred into communication of artificers, I will make devision of theim. Some of theim doe but bringe monie oute of the countrie; some other, that which they doe get, they spend againe in the countrie; and the third sorte of artificers be they that doe bring treasour into the countrie... Thearfore, we must cherishe well the third sorte.... ${ }^{\mathrm{r}}$

This was done as far as possible by trying to make the export trade exceptionally profitable.

It was on these grounds that all the specifically mercantilist projects were launched; projects aimed at securing an identity of public and private interests. A writer demanded protective measures against the importation of foreign-caught herrings in 1615. If these were granted, he said, "Wee may now resort againe to the sweete fountaine of profite; which besides that it watereth our priuate estates with the continual spring of great gaine..." would also serve to keep treasure in the country, to fill the customs, increase the might of the kingdom through its navy, relieve unemployment and perform many such useful offices for the state. ${ }^{2}$ The author of a more definite and detailed scheme for advancing the fishing industry also claimed that the great advantage of his project was that it provided opportunities for performing one's duty towards one's country at a profit:

The propertie of a Merchant is to have money in his purse, and creditt on ye Burse to advaunce his Trade. All men in this worke must become Merchants, not only for themselves, but for their Prince and countrey; all are to reape profitt thereby, none paine or sorrowe, but the sloathfull idle base people, who are like droanes among the Bees, for the purchase of sloath is despaire. ${ }^{3}$

I Discourse of the Common Weal, pp. 91-2.

2 J. R., The Trades Increase, p. 46.

3 University Library, Cambridge, MS. Gg. v. 18 (5), folio 199 back. 
It became increasingly common to preach the necessity of expanding trade both as a social duty and as a private gain:

I heard a worthy Marchaunt in his time Thomas Cordell of London say, that on the first beginning of the Turkey Trade, his selfe with other Merchants, hauing occasion to attend the late Queens Maiesties Priuy Councell about that businesse, they had great thanks \& commendations for the shippes they then builded of so great a burden for those partes, by the Earles of Bedford and Leicester, and other honorable Personages, with many encouragements to goe forward (euen to vse their owne words) for the Kingdomes sake, notwithstanding it was then to their great benefite likewise, whose ordinarie returnes at the first were three for one, which I speake not out of enuy.... ${ }^{\mathrm{r}}$

The expansion of trade had become one of the chief aims of government policy with the appearance of the Renaissance state. This fitted in very well with the inclinations of merchants. But it was only natural that doubts arose as to whether the restrictions imposed by government in the interests of trade did not hinder rather than help.

In Dr Wilson's Discourse on Usury of 1572 , the merchant of the dialogue was made to say:

Hope of gayne makethe men industrious, and, where no gayne ys to bee had, men will not take paynes. And as good it is to sitt ydle and doe nothinge, as to take paynes and haue nothing. Merchants doings must not thus be overthwarted by preachers and others, that can not skill of their dealings. And thys over great curiositie of some to meddle in other mens matter, I muste tel you plaine, it is even the verie right waye to undoe al in the ende. Therefore saie what you will, I will lyve and amend, so as I may lyve every day better and better, by any meanes, I care not how. Yea, I wil make harde shifte with the worlde, and strayne my conscience narrowly, before I will eyther starve or begge, both I and my chyldren after me. Provided always that I wil not come within the compasse of positive lawes: and thys I wote well, that by all lawes a man may take asmuch

$$
\text { × J. R., op. cit. p. } 6 .
$$


for hys owne wares as he can gette, and it is no synne for one man to deceyve an other in bargayning, so that it bee not to muche beyonde gods forbode, and a bargaine is a bargayne, let men saye what they list.... ${ }^{\mathrm{I}}$

It was not only against the interference of preachers that the merchant, Gromelgayner, wished to protest. He not only intended to be restrained by none but the positive laws; he claimed that these should not be allowed to press too hard and too narrowly upon him. "Men are loth to bee comptrolled in theire ordinary and accustomable trades of geattinge", he said, and he protested not merely against interference by the Church, but also against interference by the government as represented by the civil lawyers. The merchants were inclined to believe that governments as well as preachers could not "skill of their dealings", and those who were not sufficiently revolutionary to suggest a laissez-faire policy were all loud in their clamours for a business government at the end of the sixteenth and during the seventeenth centuries. The example of the Netherlands and of the Italian cities, where the state was controlled by merchants, was watched with envy, ${ }^{2}$ and the project of a "State Merchant" for England was very popular, chiefly because it was thought that the administration of a State Merchant would be more sympathetic towards mercantile needs than that of "meer Statesmen". Thus the clamour for a state merchant was really a demand for freer trade. It represented a claim for a less irksome and more commercially reasonable interference on the part of

x Wilson's Discourse on Usury, ed. by R. H. Tawney, pp. 250-r.

2 University Library, Cambridge, MS. Gg. v. 18, p. 515: "And lastelie, if you please to turne yor eyes vpon the Gouernmt of the lowe Countries, which excell both in State policie \& Trade, you shall finde the most parte of theire Statesmen, to haue been Marchauntes; who by power given them, doe their Countrie more service, then all their meere Statesmen doe, or Can. Also if you please to looke into Italy, both the Great Magnifico's of Venice, and your Politicians of Genoa, which are esteemed two of the most pollitique Gouernmentes of Christendome, are Cheifely composed of Merchantes...". 
those who had not advanced to the point of denouncing government interference altogether.

But even this demand that state interference with commerce should be directed by trade experts was not the limit. The utility of all interference was sometimes questioned. In $155^{\circ}$ Sir John Masone had written to Cecil:

I hear here a great bruit of the discontentation of our people upon a late proclamation touching cheese and butter; of a little thing we make here a great matter. And surely, if there be no other thing than I do see in the thing, the matter might even as well have been spared. I have seen so many experiences of such ordinances; and ever the end is dearth, and lack of the thing that we seek to make good cheap. Nature will have her course, etiam si furca expellatur; and never shall you drive her to consent that a penny-worth of new shall be sold for a farthing. If good cheap follow this device, then hereafter will I think it were good the like were still used; but this I am sure, the thing shall not be so plentiful as it was, and then I report me to you whether it will be better cheap. For who will keep a cow that may not sell the milk for so much as the merchant and he can agree upon??

Even at this early date, then, the free market was advocated as the only means of securing adequate supplies of goods for consumption at reasonable prices. Similar criticism of the various attempts to coerce farmers and landlords into adopting definite systems of tillage was made later by distinguished statesmen. In 1601, at the second reading of a bill for making compulsory the sowing of a certain proportion of hemp, Sir Walter Ralegh said:

For my part, I do not like this constraining of men to use their grounds at our wills. Rather let every man use his ground to that which it is most fit for, and therein use his own discretion. For hawsers, cables, cordage and the like we have plentifully enough from foreign nations. And we have divers counties here in England

I P. F. Tytler, op. cit. 1, p. 340. Also Tawney and Power, Tudor Economic Documents, II, p. I88. 
make thereof in great abundance. The Bill of Tillage may be a sufficient notice to us in this case not to take the course that this Bill tendereth. For, where the law provideth that every man must plough the third part of his land, I know that divers poor people have done so (to avoid the penalty of the Statute), when their abilities have been so poor that they have not been able to buy seedcorn to sow it withal; nay, they have been fain to hire others to plough land, which, if it had been unploughed, would have been good pasture for beasts, or might have been converted to other good uses.

He made observations of the same sort when the repeal of the Statute of Tillage itself came in question. He feared that the Act would cause an over-production of corn relative to other commodities, and he deprecated the policy of trying to make England a self-supporting country by coercive measures. "I think the best course", he said "is to set it at liberty, and leave every man free, which is the desire of a true English man."I

This point of view was put even more forcibly in a memorandum placed before the commissioners on enclosures in 1607 . Enclosure for pasture had been forbidden in certain counties

I Ralegh's remarks were: "I think this Law fit to be repealed; for many poor men are not able to find seed to sow so much as they are bound to plough, which they must do, or incur the Penalty of the Law. Besides all Nations abound with Corn. France offered the Queen to serve Ireland with Corn for sixteen shillings a quarter, which is but two shillings the bushel: if we should sell it so here, the Ploughman would be beggered. The Low-Countryman and the Hollander which never soweth Corn, hath by his industry such plenty that they will serve other Nations. The Spaniard who often wanteth Corn, had we never so much plenty, will not be beholding to the Englishman for it, neither to the LowCountry men, nor to France, but will fetch it even of the very Barbarian. And therefore I think the best course is to set it at liberty, and leave every man free, which is the desire of a true English man". These speeches are both quoted in Edwards' Life of Ralegh, I, p. 272; they are also to be found, the first in Hayward Townshend's Last Four Parliaments of Q. Elizabeth; the second in D'Ewes' Journals of all the Parliaments of the reign of $Q$. Elizabeth. 
(while allowed in others) by the 1597 Statute of Tillage. In this memorandum it was claimed that it ought to be made lawful to enclose for that purpose in any county, as it was unjust to give one group of counties a competitive advantage over another. It was also claimed that freedom was necessary for the prices of corn and wool to find their relative natural levels:

"The good individual is the good generall", it said, "for Corn being dearer then Cloath or meat comparatively the Husbandman will plough; since his only end is profit, if equal or under no reason to constrain him. For that the Law wch divideth labour from profit (as the Act of Tillage) is that wch causeth the great difference of the wealths $\&$ abilities of several shires as they are oppressed wth that statute." I

The policy of state control was being blamed for empoverishing the countryside, instead of, as was intended, making it richer.

Emphasis of the beneficent nature of private enterprise comes out even more strongly in what appears to have been the rough draft of this memorandum:

It [i.e. the liberty of converting arable into pasture] can be no cause of Dearth for the end of the husbandmen being gaign, iff corne be dear, he will plow if chep no wise to beggar him by a law. For scarcity being the caus of Dearnesse-and the redress therof the end of prouidence, no means can be so wise and certen to work this remedy as by Discretioning the farmer whose laber euer leading to proffitt doth ayme at the dearest commodity. And so then consequently if tenements may be vypheild and ingrossing preuented the priuatt gayne of euery such perticuler man wil be the generall proffitt of the stait.... ${ }^{2}$

r Brit. Mus. Lansdowne MSS., 487, pencil folio 218 . This document is given also as an appendix to Cunningham, Growth of English Industry and Commerce, II, pp. $897-8$.

${ }^{2}$ Brit. Mus. Cott. MSS., Faustina C II, folio rgo: "In defenc of Inclosuer...". This includes in an unfinished form all the arguments of the Lansdowne MS. quoted above, and an additional argument that to restrain such enclosures is to endanger London's meat supply. 
The same arguments as to the preferability of unrestrained private enterprise are to be found in the defence of the goldsmiths against the proposal, which was frequently made in the reign of James I, to nationalise the exchange business by reviving the royal monopoly managed by a Royal Exchanger. They pointed out that a state monopoly was only suitable when private enterprise was unable to perform the task- "The Exchangers office was only vsed in the tyme of ignorance, when gouldsmithes were fewe and poore, not able to buy Bullion, and for some other causes nowe ceasinge". $\mathrm{x}$

To revive this office would be at the expense of trade; the goldsmiths affirmed "that the Office sought to bee renewed, hath been so long out of vse, That the sudden alteration will bee a great hindering to the Trade and vent of Cloth". ${ }^{2}$ They complained that "it will take awaie the freedome of every subject to bring Bullion to the Mynt to be coyned"'.3 They even naively exposed the manner in which they made a practice of evading the restrictions of mercantilist governments:

It will be dangerous to the liues and States of Merchants that import Bullion, to be enforced to bring it to one hand onely; by which meanes their importation of Bullion of forreine Countries may be reuealed. It being in most kingdomes Capitall or confiscation of goods to Export Bullion. ${ }^{4}$

Finally they brought forward the argument which is at the root of all claims to conduct affairs on the basis of private enterprise. It was proposed that the Royal Exchanger should charge usance at the rate of ro per cent.; it was therefore asked:

Merchants will exchange for lesse than io in the roo, whye shoulde it not be lawfull then that euery man may make his market at the beste hande? 5

I Brit. Mus. Add. MSS. Io, I 13, folio I46. A petition of the Goldsmiths' Company to Sir Julius Caesar.

2 A petition of the goldsmiths quoted in Cambium Regis; or the office of H.M. Exchange Royal (1623), p. 22.

3 Brit. Mus. Add. MSS. Io, I1 3, folio 146. 4 Cambium Regis, p. 22.

5 Brit. Mus. Cott. MSS., Otho, E x, folio 50. 
These arguments of the goldsmiths were undoubtedly prompted merely by their own greed of gain and not by any deeply rooted rational belief in a doctrine of laissez-faire. That does not make them any less important. It was in this way that a general belief in the doctrine of individualism was spread. The desire to rationalise private interests into public benefits was strong even in the sixteenth century, and grew in strength during the seventeenth. Though the more common theory was that expressed by Malynes:

For albeit the generall is composed of the particular, yet it may fall out, that the particular will breed a great inconuenience to the generall, whereby priuate persons may reape a benefit to the hurt of a multitude..., $\mathrm{I}$

there were many who believed, with the author of the memorandum on Enclosures and Depopulation, that "the good individual is the good general". Such a belief was not uncommon as early as the middle of the sixteenth century.

"I haue hard oftentimes much Reasoninge in this matter" [said the Knight in Hales' Discourse of the Common Weal], "and some, in mainteyninge of these Inclosures, would make this Reason. Euerie man is a member of the common weale, and that that is proffitable to one maie be proffitable to another, yf he would excercise the same feat. Therfore, that is proffitable to one, \& so to a nother, maie be proffitable to all, and so to the common wealth. As a great masse of treasure consisteth of manie pence, and one peney added to a nother, and so to the thrid and fourth, yt maketh vp the great somme; so eache man, added to a nother, maketh vp the whole bodie of the common weale." 2

Mercantilism had not developed a fixed and orthodox doctrine -for the policy of mercantilism was pure pragmatism-and there was much in the beliefs of the earlier mercantilists which looked beyond the state-worshipping philosophies of Bacon or Hobbes to the liberalism of the eighteenth century. Bodin was

I Gerard Malynes, Lex Mercatoria (1635 ed.), p. 275.

${ }^{2}$ P. 50-I. 
not alone in believing that "la trafique... doit estre franche $\&$ libre, pour la richesse \& grandeur d'vn Royaume". I Ralegh had written in his Essay on Government-

It is a difficult piece of Geographie to delineate and lay out the bounds of Authoritie; but it is easie enough to conceive the best use of it....

... In respect of the first sort of men, to wit of those that live by their own labour [i.e. husbandmen], they have never been displeased where they have been suffered to enjoy the fruit of their own travels. Meum and Tuum, Mine \& Thine, is all wherein they seek their certainty \& protection...

... The second [i.e. merchants] have seldome or never offended their Princes, to enjoy their trades at home upon tolerable conditions, hath ever contented them for the injuries received from other Nations; give them but the Commission of Reprisal, they will either Right themse!ves, or sit down with their own losse without complaint....2

These practical considerations of the benefits of commercial liberty had not, any more than the restrictive tendencies in mercantilism, crystallised into a coherent doctrine. The pamphlet on Trade and Commerce with the Hollander was written with the object of explaining the benefits of Free Trade as practised by the Dutch. Yet it contains pleas for setting up a state merchant, for encouraging the cloth-finishing trades by abolishing the licence of the Merchant Adventurers to export unfinished cloth, for state encouragement of fishing, and similar purely mercantilist objects. Sir Walter Ralegh believed that all a true Englishman wanted was freedom to carry on his business affairs untrammelled by authority. Yet he held, and defended in Parliament, a monopoly of the pre-emption of tin, and he also held for some time a profitable monopoly of licensing ale-houses. Similar inconsistencies were common to most of his contemporaries, and have been indeed to most people before

I Jean Bodin, Response aux paradoxes du Sieur de Malestroict, folio 62.

2 Sir Walter Ralegh's Remains (I66I ed.), pp. 156-7. 
and since. But all the elements which are necessary to a doctrine of complete economic individualism were there.

There remains the question of whether these movements towards greater commercial freedom were connected with Calvinism. For it is obvious that without this individualistic transformation the Renaissance state would not have helped to form our modern capitalism. Not every influence emanating from that state has been in favour of capitalism. Some have worked in one direction, some in another. The policy of mercantilism was intended to be an alliance between the state and growing capitalist interests. In fact, owing to the ill-chosen nature of most of the state measures for fostering economic development, the alliance rarely proved much of a success. Hence the importance of the movement to relax the restrictions imposed by mercantilist governments in completing the capitalistic orientation of the state.

The trade policy of states remained that of privilege. Political monopolies were granted in the hope that their grant would lead to industrial development. Foreign trade was extensively monopolised. Sixteenth- and seventeenth-century states had large pretensions, and an extensive circle of government. But lacking the means to pursue a commercial policy of direct intervention, they granted privileges to companies which would regulate trade for them.

It was. hoped that economic activity might be stimulated by grants of the exclusive right to indulge in some form of business, by increasing the incentive to those who were given the monopoly. But in reality all that resulted was a barrier to the expansion of capitalistic enterprise. Mercantilist ideas of social control lent themselves very easily to attempts to secure privileged fields for investment-which thus diminished the productivity of investment as a whole. The old-established capitalists attempted to establish control of the chief fields for promising investment and freeze out the newcomer. It was in part a reflex of the great increase in free capital resulting from the discoveries, which tended to reduce the earnings of capital 
already invested. ${ }^{\mathrm{I}}$ But it was foreign to the main trend of capitalist development. It descended from the medieval idea of privilege as the basis of activity. And it tended to a traditional ordering of commercial affairs. ${ }^{2}$

Capitalism had, then, to combat this internal enemy-legal monopoly. It has been suggested that, in England, Puritanism acted on its behalf and provided the opposition to monopolies, which it considered to be the schemes of a High Church administration, and that the monopolies disappeared because they were identified with the "Church and State" policy of Archbishop Laud.3 There is little reason for supposing that Puritanism had anything directly to do with it. Monopolies went because of the exceptional opprobrium which their operations aroused. "Nearly all the monopolists promised to supply a better quality more cheaply. In no single case was this promise fulfilled." 4 Is it necessary to go beyond Professor Levy's verdict to explain the fall of the industrial monopolies along with the fall of the government which profited fiscally from their operation? This view is supported by Continental experience. It was not only Puritans who were opposed to the operation of monopolies.

In 1556 a Piedmontese, Jean-Baptiste Ferrufini, brought forward a proposal to Philip II to institute a corporation of official insurance agents, to remedy frauds and abuses which

I On the influence of the discoveries, see below, ch. vii. Cf. W. R. Scott, Joint-Stock Companies to 1720, I, p. I I0: "During the first twenty years of the reign of Elizabeth capital was so exceedingly scarce in England, that it was welcomed from any source, even from abroad. After a series of good years there was a considerable accumulation. Had trade been prosperous in the last years of the sixteenth century, in view of the large war-expenditure, it is probable that merchants would have been glad to obtain capital from other classes. But with the depression of trade... merchants were anxious to limit competition to their own class at least...".

2 This has been very rightly pointed out by Max Weber, loc. cit. p. 50 (Engl. trans. p. 65).

3 Ibid. p. 201 (Engl. trans. p. 179); Troeltsch, The Social Teaching of the Christian Churches, Engl. trans. p. 679.

${ }^{4}$ Hermann Levy, Economic Liberalism, Engl. trans. p. 30. 
were prevalent in this class of business at Antwerp. He suggested that all insurance broking should be confined to a body of four sworn agents, under a superintendent. The project aroused violent opposition amongst the merchants trading in the town. At once a protest was sent by "the community of the merchants of all the nations" against the scheme. It was a long document, the contents of which can only briefly be indicated here. It pointed out that the chief cause of Antwerp's prosperity lay in the freedom which commerce enjoyed; and that the experience of Bruges in restricting the freedom of merchants should be an example of what ought not to be done. The example of Bergen ought also to suggest the inadvisability of giving privileges to a few, and so making the many prefer not to carry on trade there. Ferrufini's scheme would be the thin edge of a wedge which would spell ruin for the town: "If freedom of commerce should not remain in its entirety, this town and its commerce would become like a body infected with contagious maladies, which having first attacked one member of the body, little by little would come to infect the whole"one would never know where the policy of interfering with economic freedom would stop. The merchants' interests would be ill-served. They would no longer have the freedom to go to whichever broker they wished, and so would have to accept the policy which the broker chose, instead of being able to demand a policy to suit themselves. Similarly they would be unable to get competitive quotations of premiums for a policy.

It was argued that the proposal would abolish fraud. The merchants doubted if this would be its effect:

It is, moreover, unbelievable that these four brokers should have some Divine privilege not to deceive merchants in every way in which merchants may be deceived by ordinary brokers. It is more likely that they will have greater freedom and opportunity for deceit, on account of their great privilege and authority, and because they will have a monopoly, and because of the great need of the merchants who will fall into their hands. 
In any case, the brokers were not primarily responsible for frauds. The merchants had the remedy in their own hands. It was their own fault if they did not read their policies; and they could always give a wide berth to a dishonest broker so long as brokerage business was not confined to the hands of a few. Every monopoly was contrary to common sense and justice. The violation of business freedom would only bring evils and inconveniences. This vigorous defence of economic freedom was not the work of Puritans. It was made by merchants who understood where their interests lay and objected to these being overruled by those who did not. ${ }^{\mathrm{I}}$

The Italian community almost to a man signed the manifesto, and with the Spaniards and Portuguese formed the majority of signatories. It is unlikely that these were non-Catholics, and no doubt many of the other signatories were also Catholics. ${ }^{2}$ The episode shows that opposition to monopolies was not an effect of Puritanism.

The merchants of Antwerp protested equally against an exclusive body of factors in 1642, repeating the arguments of I557 against the illogicality of placing the brokers in the

I Cf. article 36 of the memorandum: "Mais, que plus est, l'université des marchans, tant des nations estrangiers que ceulx du pays, voire ceulx de ceste ville, grans et petitz, una voce et de commun consentement, detestantur et abhorrent telle ordonnance et la jugent pour inique et cruelle, et on dit communément: vox populi vox Dei, de sorte que tel magistrat de couretiers ne seroit seullement contre le consentement universelle, ains aussy contre la voix de Dieu. Si tel ordre seroit proufitable et bon, affin de ne altérer les marchans et de ne faire violence à la liberté de la négociation, on ne le debvroit admectre sans le consentement desdictz marchans. Mais estant si mauvaise et pestiféré, comme on a remonstré, seroit contre nature et hors de toutte humanité de l'introduire contre la volunté desdictz marchans". Perhaps we underestimate the effects of commerce in stimulating the democratic feeling which is often attributed to religious causes.

2 P. Génard, "Jean-Baptiste Ferrufini et les Assurances Maritimes à Anvers" (Extrait des Bulletins de la Société Royale de Géographie d'Anvers, 1882); E. Dilis, Les Courtiers anversois sous l'ancien Régime, pp. 34 ff.; J. A. Goris, op. cit. pp. $187 \mathrm{ff}$. 
position of dictating to the merchants. I Similar protests were made in France against the monopoly of importing spices and Eastern products. ${ }^{2}$ What has Puritanism to do with them?

Another example of that individualism which Puritanism is said to have introduced is found in an important speech of the Venetian senator, Contarini, in 1587 . He was pleading that the business of a bank of issue should not be confined to a public bank, but that private banks might be allowed to avail themselves of the privilege. He admitted that there had been in the past too many bank failures. This, he said, was not due to their being private banks but to their carrying on business inefficiently. They had lent incautiously, had meddled too much with trade, had not kept their assets liquid enough. This evil might be avoided by providing for the institution of regular settling days when the bankers must settle their accounts. 3 But if a public bank was set up it would prove a permanent temptation to the government in time of need. 4 The dangers attached to private banking would not be abolished by making it a state monopoly. For instance, the risk that the officials of a public bank would lend merely for the sake of friendship was as real as the danger that a private banker would do the same:

Our nature is indeed such that we easily say "yes" to friends who are seeking some favour or accommodation of us. The ancient and

I Dilis, op. cit. pp. 4I ff.

2 "Louis XI ayant concédé à une compagnie le droit exclusif d'importer les épices et autres produits du Levant par les 4 galères d'AiguesMortes et de Narbonne, les États de Languedoc reclamèrent: 'Qu'il soit loisible à tous marchands de pouvoir marchander tant hors le royaume es pays non contraires au Roy que dedans par terre et par mer" (J. MoriniComby, Mercantilisme et Protectionnisme, p. I5, n.).

3 E. Lattes, La Libertà delle Banche a Veneżia, pp. 158-9.

4 Ibid. p. 153: "But if the money of divers merchants were to be found in the public hands, every one would live with anxious mind and uneasy heart, fearing lest the Venetian Senate might not be obliged to make use of it through some accident of war or other public need...". This objection was, of course, later made against the foundation of the Bank of England. 
immutable custom of this city is of such a kind that it is with difficulty that one gives a refusal to somebody who asks a service. Reasons of interest, of ambition, relationship or other intercourse are so powerful amongst us that they overcome any hindrances which may be opposed by the laws, statutes or by the Prince himself. We are born with this tendency; we are brought up in this way; we are nurtured in these ideas-we can only act in this manner. ${ }^{I}$

Thus Contarini expressed his opinion not only that the superiority of the public bank was imaginary, but also that repressive legislation in general was futile. The laws, he said, could not compel honesty, much less business prudence:

How many offices are there in this Republic which handle money! How many severe laws prohibit touching it! How many penalties menace the honour and the goods of the man who puts forth his hand to steal the public money! And in spite of all this one finds no office, no cash-chest, where cupidity does not at some time overcome fear, and desire the prohibition, so that it happens that it is embezzled by him who has charge of it. ${ }^{2}$

What was the use, then, he argued, of trying to regulate men, who are by nature impatient of restraint? Contarini saw the problem as a matter not of morals, but of business expediency. He was not concerned with the moral justification of an individualistic attitude. He only asked that commercial legislation should take into account the fact that it was impossible in practice to restrain men by regulations which were contrary to all their natural inclinations. So he opposed the policy of restrictions and monopoly. He was assuredly no Puritan. But the conclusions which he drew were the individualistic ones which we are asked to believe first emerged in a Puritan struggle against Anglo-Catholic monopolies.

It is not necessary to rely on these Continental cases to show that opposition to monopolies had a practical and not a religious basis. It can be demonstrated conclusively within England

$$
\text { I Ibid. p. } 145 \text {. }
$$

${ }^{2}$ Ibid. p. 143 . 
itself. The strong opposition which grew up in the latter part of the sixteenth century to the monopoly of the Chartered Foreign Trading Companies such as the Merchant Adventurers was due entirely to commercial causes. I It was realised that the claims of the excluded traders and of the industrial workers were true-that monopoly hindered the sale of English products abroad by confining it to a few markets where high prices might be obtained even at the expense of comparatively small sales. All relevant documents, and the mere fact that the strongest opposition to the companies always came at periods when they were obviously not fulfilling their purpose of disposing of the country's export surplus, show that the real opposition came from the belief that:

It is not all vented, which the land might spare; and that by reason of the courses held by these Companies, to their own excessive gain, and certain loss of all other men; besides, when traffick shall flourish with us, as doth in other countries, where trade is free... . Things merchantable will increase daily by this encouragement to the subjects industry, even as there they do....

It may be true that all, or nearly all, Puritans were opposed to these monopolies. Practically all those who wanted Welsh Disestablishment were also in favour of Irish Home Rule. But that does not mean that the one had any organic connexion with the other. ${ }^{2}$ The monopolies were sufficient cause in themselves for any opposition they aroused.

It is obvious that there must be a close connexion between legal institutions and the existence of a cultural milieu favourable to the capitalist spirit. But it should be noticed that particular legal systems were not of so much importance as the use which their practitioners made of them. Over most of the continent of Europe the reception of Roman Law was of the

I This I hope to prove at greater length elsewhere.

2 What I have to say on the tendency to Nonconformity amongst the English commercial middle classes should make this point clear. Cf. below, p. 175 . 
greatest moment in providing a favourable institutional basis for capitalism. This was especially marked in Germany. I But in France the liberal school of Du Moulin, Hotman and others, comprised both native and civil lawyers. And in England the power of the common law and its successful resistance of the Roman invasion were amongst the factors favourable to the spread of economic individualism. "The dependence of constitutional government on the survival of the common law", said Professor Tawney, "is a commonplace. The significance of that survival for the rise of economic individualism in England has been less emphasised, but it is not less important."'2 Clearly then the survival of any particular code of law was at most a material cause and not an efficient cause of the rise (or the spread) of the spirit of capitalism.

It would need a detailed study of jurisprudence to determine why in one case the cause of individualism should have been served by the success, in another by the lack of success, of the movement to universalise the civil law. At a cursory glance, it would appear that the reason lay in political conditions. In Germany the reception of the Roman law brought Roman individualistic doctrine, but not Roman justice. There was no strong centralised government, so that the reception of Roman law merely swept away the restrictions of feudal law; it did not tend to the greater glory of the state. But in England the notion of imperial authority was the chief discovery of the civil lawyers. The civil law was the law of the prerogative courts, and its introduction into England did not stand so much for progress and emancipation from feudalism as for conservatism and a relapse into absolutism. The restrictive side of mercantilism was represented by the civil law; the liberal side, which believed that the best way to secure a strong and healthy development for a state was to grant freedom except where this

I Cf. J. Janssen, History of the German People (Engl. trans.), passim, especially II, p. IO3.

2 Tawney, Introduction to Wilson's Discourse on Usury, p. 13. This sums up the argument of his pp. II-I3. 
had proved or was likely to prove to be definitely harmful, was represented by the common law. Thus it was not so much the Roman or the common law itself which was responsible for the development of individualism, as the circumstances which led to the adoption of the one as the sign of royal authority, of the other as the sign of the protest against royal arrogance. The individualistic aspects of the civil law were obscured by its practitioners, while the individualism of the common law-which was naturally considerable, as with all codes which are made up of decisions in particular cases-was enhanced by its supporters. The legal systems were, in fact, simply materials which were moulded by those who favoured a presumptive economic freedom, or by the supporters of a presumptive overriding state control, to suit their own purposes. The triumph of the common law in England did not act as a primary factor in stimulating an individualist movement. It was rather a witness of the strength of the movement.

An increasing interest in another branch of the Roman code had followed the sixteenth-century revival of the Roman law. In this branch the magnification of the functions of the state could play no part, as it was a code designed for the conduct of the relations between those who did not owe the same allegiance, who were citizens of no one state. This branch of law was the Jus Gentium, which was based upon the common practice of all nations. It was the common denominator of all legal systems, of which it was supposed to be the ideal basis, itself derived from natural reason. The conception of this Platonic ideal of law to which the positive codes ought to approximate as far as possible was one which made its fortune in the sixteenth and seventeenth centuries. It was the kernel of the doctrines of Natural Law and Natural Right; doctrines which by stressing the natural rather than the state-created, the rights of the individual apart altogether from organised society, served the cause of individualism. The English common law is a good assimilator, and the English lawyers were very willing to adopt these agreeable doctrines and incorporate them in their 
own jurisprudence. So natural individual rights were identified with the common-law rights of the free-born Englishman, and natural rights and the common law worked in double harness. In I628 the Committee of the House of Commons on the Liberty of the Subject resolved:

That the ancient and undoubted Right of every free Man is, that he hath a full and absolute Property in his Goods and Estate, and that no Tax, Tallage, Loan, Benevolence, or other like Charge, ought to be commanded or levied by the King, or any of his Ministers, without common assent by Act of Parliament: Agreed; Nemine contradicente. ${ }^{\mathrm{I}}$

The individual subject had, then, property rights which largely excluded the state. In this matter the English jurisprudence was even more individualistic than the Dutch. And even before the end of James I's reign, natural law philosophies had reduced the majesty of kingship to something which ought to have been most acceptable to a nation of shopkeepers:

...Property caused Contracts, Trade, and Traffique, which could not be ministered without a King or Magistrate, so as the first and principal cause of making Kings, was to maintain property and Contracts, and Traffique, and Commerce amongst men. ${ }^{2}$

It is almost an individualistic economic interpretation of history. But it teaches far more about the rise of philosophical opinions on the basis of merchants rationalising their desires into principles of statecraft than it does about the true origins of kingship. It shows where so many contemporary interests lay-in contracts, trade and traffique! Unfortunately too little of the economico-political reasonings of the sixteenth and seventeenth century merchants has been preserved. Little, probably, was written, as they were too busy with their proper activities. But those reasonings which have been handed down

I Journals of the House of Commons, I, p. 878.

2 Sir John Davies, Concerning Impositions, ch. vii (in Sir John Davies' Works, ed. by Grosart). This was dedicated to King James "in the latter end of his reign". 
are mainly the work of merchants or of men influenced by the merchant's point of view. Such people provided most of the economic literature between the sixteenth and the end of the eighteenth centuries, writing (as a rule) on practical questions. ${ }^{\mathrm{I}}$ And we have seen that their interests came to receive consideration from lawyers and statesmen. It is evident that the most effective economic thought of this period came from the merchants; thought which on broad lines represented a movement towards a more liberal economic policy, and it was this thought which prevailed. The regulative side of economic policy was seen not to be transcendentally justified and secure from criticism, and criticism tended to bring amendment. Through the influence of this merchants' thought a complete alliance between the Renaissance state and the spirit of capitalism was secured instead of a partial one. From the very beginning there was a tendency to liberalise mercantilist policy. Therefore, the coming of the Renaissance state was a much greater step towards the regime of economic freedom than is always realised. It can be taken as providing a cultural milieu much more favourable to the capitalist spirit than appears at first sight, while even a superficial view shows that it provided much more favourable surroundings than those of the Middle Ages. This favourable milieu provided by the rise of the Renaissance state, and by the liberalising influences which affected the policy of the Renaissance state in the interests of the merchant, has nothing to do with the Protestant Ethic. It was purely secular. The rise of the Renaissance state explains some part of the noticeable spread of the capitalistic outlook on affairs in the

I Cf. Brentano, "Entwickelung der Wertlehre", in Konkrete Grundbedingungen der Volkswirtschaft, pp. 364-5. This fact accounts for the prevalence of subjective value theories amongst them as opposed to the medieval conceptions of objectively fixed values. This was because of the tendency to consider problems of value from the standpoint of the merchant whose business lies in taking advantage of differences in subjective valuation. The general connexion between subjective value theories and a capitalistic outlook and between objective theories and a nonor anti-capitalistic outlook is not accidental. 
sixteenth and the seventeenth centuries. The rest is explained by the rise of merchants (and those who thought as the merchants) to a position of importance and influence in the state. The rise of the capitalist spirit has been in the main a function of the growth in importance of merchants' capital. For this growth causes other than Calvinism were presumably responsible. At least it is difficult to prove the contrary. 


\section{Chapter IV}

\section{CALVINIST THEOCRACY AND JESUIT CASUISTRY}

Scotland remained more feudalised, less affected by the growth of the new state-system than most countries of Western Europe. The rise of rationalism in economic affairs was much slower in Scotland than elsewhere, owing to the overwhelming power of a theological outlook enforced by the masterful Presbyterian Church. Partly as a result of this, the economic development of Scotland in the seventeenth century was comparatively slow. Yet Scotland is often cited as an example of a country whose exceptionally rapid economic development was caused by the whole-hearted national adoption of Calvinism. It is forgotten how long Scotland was both Calvinist and poor before the remarkable economic progress of the later eighteenth and nineteenth centuries.

The germ of the Scottish argument was provided by Max Weber, although he did not himself employ it. But he suggested, in his essay on the Protestant Ethic, that Calvinism was more akin to Judaism than to Christianity. As a result we find that other writers have been led to suggest that Calvinism acted as the liberator of the capitalist spirit by making general a theology based on the worldly-wise sections of the Book of Proverbs, while relieving the faithful of the restrictions caused by the observance of the Jewish law.I This suggestion has been made to apply particularly to Scotland. ${ }^{2}$

Archdeacon Cunningham seems to have based his work in this sphere on the common appraisal of the Scottish national

I See, for example, Louis Rougier, "La Réforme et le Capitalisme moderne", in La Revue de Paris, October 15 th, 1928.

${ }^{2}$ Largely by W. Cunningham in his Progress of Capitalism, and his Christianity and Economic Science. 
character first made public by the popular preacher, Thomas Lever, when he warned his congregation to beware of the covetousness of Scotland entering their hearts. A critic of capitalism, and a staunch enemy of Presbyterianism, Cunningham seems to suggest that by the adoption of the Elizabethan system of Church government and the Thirty-nine Articles England had managed to secure the fulfilment of Lever's advice to Edward VI - " to take good and diligent heede when ye be chasyng the wylde fox of papisticall supersticion, that the greedye wolfe of couetous ambicion, do not creepe in at your backes: For surely he wyll doo more harme in a weeke, then the foxe did in a yere". But he suggests that Scotland, by adopting the reformation of John Knox, remained in a less happy state:

The Mes, that Idoll—praysit be God! —is past,

But Couatyce, the quhilk is cum in last,

Is the worst Idoll of the twa, be fer.... I

A thorough examination of this argument seems to be so necessary that a lengthy quotation of its most elaborate form is called for:

Unemployment and idleness were the characteristic evils of Scotland in the seventeenth century; to get the population to submit to the discipline of work might well be regarded as the first step towards introducing a godly, righteous and sober life into the community. There were no half measures about the treatment of vagrants in the Scots Act of $1663 .{ }^{2}$ Enterprising men, who set up manufactories, were empowered to impress any vagrants and employ them for their service as they should see fit for eleven years, without wages except meat and clothing. Good subjects were recommended to take into their service poor and indigent children, who were "to do any task assigned them till they had attained the age of thirty, and to be subject to their masters' correction and chastisement in all

${ }^{I}$ Lauder, Ane Godlie Tractate (Early English Text Society, Original Series, XLI).

2 Which re-enacted the Acts of 1579, c. 12; 1597, c. 39; and 16r7, c. 10. 
manner of punishment (life and torture excepted)"'. The seventeenth century presbyterian took a stern view of the discipline which was good for children, so that they might be kept from forming habits of idleness and from drifting into evil of every kind. The best hope for the future of the country seemed to lie in providing conditions which were favourable for the investment of capital; to develope the resources of the country and to start fresh industrial enterprises might seem to thoughtful men to be the best remedy for existing social evils. The well-doing population were for the most part still attached to the soil and well able to draw their livelihood partly from rural occupations and partly from wages; the dangers of sweating and other forms of oppression by moneyed men were so remote that they were not taken into account, and capital appeared in a friendly guise as the greatest of social benefactors. Religious reasons could also be adduced in favour of cultivating the type of conduct which was favourable to capitalists. The duties of secular life are more fully dealt with in the Book of Proverbs than in any other part of the Old Testament, and the teaching in that book on social and economic matters is entirely prudential in character; the vices of the selfindulgent and the sluggard are denounced, while diligence and thrift are commended. There is an interesting picture of the domestic economy of a good housewife; and the right course in business life is inculcated as a matter of private concern which ensured a personal reward; there hardly seems to be any consciousness that there is room for the consideration of public interests or the common weal. There is nothing specifically Christian in the religious point of view which was there adopted, either as regards the dignity of work or the dangers of the greed of gain. Scottish Presbyterianism as the most complete illustration of a national theocracy on Calvinist lines, is almost exactly on the same plane as Judaism, and has not advanced to the Christian standpoint in regard to the regulation of society. The sense of public duty was little developed, while the doctrine of predestination fails to arouse to the need for cultivating Christian graces.

The statement of these principles is sufficient to show the fundamental reasons for the alliance of capitalism with Calvinism; and the most cursory survey of the character of the progressive countries 
during the last three hundred years makes the fact of the affinity exceedingly clear....

... Calvinism is a form of Christianity which gave its sanction to the free exercise of the commercial spirit and to the capitalist organisation of industry. ${ }^{\mathrm{I}}$

It must be said that the case here presented is unconvincing. There is nothing peculiarly Calvinistic or peculiarly Scottish in the treatment of vagabonds to which Cunningham referred. The provisions of the various laws by which owners of mines, salt-pans and other manufactories in Scotland were given the right to make use of forced labour were no different in kind from the provisions by which employers of different sorts in England were given similar rights by the Statute of Apprentices in 1563.2 The proposals made by William Cecil in his Industrial Programme of 1559 were much more severe in their application to the unemployed and the unskilled. 3 The only difference seems to have been that the system of forced labour worked in Scotland, being designed chiefly to ensure labour supplies for mines, which were in isolated districts, while it did not prove efficacious in England where it was designed to help the farmers and the town traders.

It does not even appear that the Scots system was made the basis for any untoward exploitation of the workman. On the wage roll in the General Register House in Edinburgh are the names of three runaway workmen from the silver mines at Hilderston, for whose apprehension the Scots Privy Council made an order in 1608.4 Two of these men were Roger Row and Alexander Percy, pickmen earning ten shillings daily for six days' work, and the third, John Spargus or Spargoth, was a smith who earned twelve shillings a day. This means that in English money they earned tenpence and a shilling a day

I W. Cunningham, Christianity and Economic Science, pp. 67-70.

2 See Clauses 3, 5, 7 and 17 of this statute.

3 Bland, Brown and Tawney, English Economic History, Select Documents, pp. 323-4.

4 Register of the Privy Council of Scotland, vili, p. 168. 
respectively; ${ }^{\mathrm{I}}$ wages above the general level for labourers so far north. Accounts of coal mines for the latter part of the century are preserved in the General Register House in which the same generally high level is noticeable.

The letting out of paupers as a free labour supply to private capitalists was common in the English parishes. ${ }^{2}$ Too much, therefore, should not be made of the provision of the Scots law that vagrants might be employed for no wages above.the cost of their food and clothing. Thomas Bushell, an English mining engineer and projector, had a scheme which seems to be not unconnected with the system which Cunningham reprobated so much in Scotland-a scheme which explains itself sufficiently in its title: "An Invitation by Letter to Condemned men for petty Felonies, to work in the Mines of their own Country rather than be banish'd to slavery in Forrein parts". ${ }^{3}$ Yet Bushell was no Scots Calvinist. He may have been an English Puritan, but this is unlikely, as he equipped a troop of horse for the king at his own expense in the Civil War, and held Lundy Island for some time against the Parliamentary forces, on the king's behalf. It was not only the Calvinists who thought that there should be some way of getting the idle and vicious to work for the profit of the enterprising.

The question of poor relief has always been bound up with the question of the "sturdy beggar", and a variant of a common type of measure has been taken as representative of a peculiarly Scots system, evolved under Calvinist influence. This is brought forward as the Scots-Calvinist solution of the problem, a solution which sacrificed the poor to the capitalist.

Yet the relief of the poor was a matter on which the Scots Church laid great store, and its courageous battle on behalf of

r Scots money was valued at only I/ 12 of the corresponding English denominations.

2 Dorothy Marshall, The English Poor in the Eighteenth Century.

3 Thomas Bushell, Abridgement of... Bacon's Philosophical Theory of Mineral Prosecutions (I660), p. 29. See also the working conditions which Bushell offered (ibid. p. 35). 
the poor against the avaricious lords who had despoiled the goods of the overthrown Roman Church was the reason why the estates did not sanction Knox's Buke of Discipline. In the fifth head of this Buke it was laid down that:

Every several Kirk must provide for the poore within the self; for fearful and horrible it is, that the poore, quhom nott onlie God the Father in his law, but Christ Jesus inn his evangell, and the Holie Spreit speaking by Sanct Paule, hath so earnestlie commended to oure cayre, ar universallie so contempned and dispysed. ${ }^{x}$

And in the seventh head it was stated that:

These twa sortis of men, that is to say, the Ministers and the Pure, togidder with the Schollis, when ordour sall be takin thairanent, must be sustened upoun the chargeis of the Churche: And thairfore provisioun must be maid, how and of whome suche soumes must be lifted. But befoir we enter in this heid, we must crave of your Honouris, in the name of the Eternall God and of his Sone Christ Jesus, that ye have respect to your pure brethren, the lauboraris and manuraris of the ground; who by these creuell beastis the Papists have bene so oppressit, that their life to thame have bene dolorus and bitter. Yf ye will have God author and approver of youre reformatioun, ye must nott follow thair futesteppis; but ye must have compassioun upoun your brethren, appointing thame to pay so reasonabill teyndis, that thei may feill sum benefit of Christ Jesus, now precheit unto thame. ${ }^{2}$

So far as it had the power, the Church of John Knox set out from the very first to protect the poor-the working poor by attempting to secure for them freedom from extortionate church teinds, the impotent poor by the provision of an adequate system of parish relief. It persevered in its efforts, despite an almost continuous appropriation of its patrimony by the crown and the nobility. The other elements in the Scots Poor Law system were in the main modelled on English law, and the treatment of the sturdy beggar in Presbyterian Scotland was at

I The Works of John Knox, ed. by Laing, II, p. 200.

2 Ibid. 11, p. 221. 
any rate less harsh than the branding and death penalties of old Catholic times.

The argument that Calvinism was (in the social sphere) nothing but Judaism is no better founded. It may be remernbered that one of the points which Calvin made in his letter on Usury was that Christians were not necessarily bound by the Old Testament. It was one of the commonplaces of the Puritan argument against vestments that these were the badge, not of Christ's ministers, but of the descendants of Aaron. In his Ecclesiastical Polity Hooker had to reply to the arguments of Cartwright, and defend the English Church for not renouncing all Jewish traditions. One should hesitate, therefore, before designating Calvinism as Jewish.

It is true that much was made of the Old Testament teaching in Scotland. But it is not true to say that the Scottish Kirk claimed an authority for the Old Testament equal to or greater than that of the New. The Old Testament was regarded, as in all Christian Churches, as a preparation for the New:

When contraversie then happineth for the rycht understanding of any place or sentence of Scripture, or for the reformatioun of any abuse within the Kirk of God, we aucht not sa mekle to look what men befoir us have said or done, as unto that whiche the Holy Ghost uniformlie speakis within the body of the Scriptures, and unto that whiche Christ Jesus him selfe did, and commanded to be done. ${ }^{\mathrm{I}}$

It is very likely that the importance of the Old Testament was over-stressed in Scotland, but it did not dominate the biblical teaching of the Kirk to the exclusion of the New Testament. Nor did the Book of Proverbs take pride of place in the Old Testament and encourage a capitalist mentality. Scots ministers have always made great use of the Psalms and the Prophets. They have employed the books of Moses with rather more care and discrimination. They have drawn inspiration from the historical books. There is no particularly "capitalist morality" to be found anywhere here. In the Book

r The Scots Confession, in Works of John Knox, II, p. III. 
of Proverbs-that queer contradictory miscellany-no doubt texts were studied which proclaimed the wisdom of the busy ant, but so were texts which extolled true wisdom, chastity, liberality - and the folly of trusting in riches. The Book of Proverbs was not the exclusive, even the favourite book of the Scots Kirk, and the lessons which were drawn from the Proverbs were by no means all of a prudential character, proclaiming the primacy of material gain over all other human ends. The Scot felt otherwise-as he was taught in a catechism he had accepted from Westminster:

Qu. What is the chief end of man?

$A$. The chief end of man is to glorify God, and enjoy Him for ever.

As Sombart has pointed out, the commercial spirit of the Jews was apparent, not in the Old Testament, but rather in the legalistic writings of the Talmud. The Church of Scotland, in accepting the Old Testament as a source of its doctrine, in common with all other Churches, never accepted the Talmud as of any weight. The glosses of the Jewish rabbis were no more binding than those of the Roman Church. Thus there is little reason why the Scots bibliolatory should have raised up a spirit of capitalism in Scotland.

"The sense of public duty", Cunningham had continued, "was little developed, while the doctrine of predestination fails to arouse to the need for cultivating Christian graces.... Calvinism is a form of Christianity which gave its sanction to the free exercise of the commercial spirit and to the capitalist organisation of industry."

The only answer to this is that it can be maintained neither logically nor actually. The sense of public duty was in Scotland developed so far that the faithful had to refrain from any action which might cause "scandal". The doctrine of predestination, so far from being a fatalistic belief militating against the cultivation of the Christian graces, called for a complete subjection to the Divine will; it aroused the need for cultivating God 
Himself. What this subjection to the Divine will meant in the economic sphere was certainly not "a sanction to the free exercise of the commercial spirit". I It resulted in a species of regulation of economic activity on moral grounds which was many times more thorough than any mercantilist regulation on political grounds.

Mankind being divided into the elect and the damned, the

I The following prayer found a place in the Book of Common Order of 1565 :

"A Prayer to be said before a Man begin his Worke.

"O Lord God, moste merciful Father and Saviour, seing it hath pleased thee to command us to travel, that we may relieve our nede, we beseche thee of thy grace so to blesse our labour, that thy blessing may extend unto us, without the which we are not able to continue, and that this great favour may be a witnesse unto us of thy bountifulnes and assistance, so that thereby we may know the fatherlie care that thou hast over us. More over, O Lord, we besech thee, that thou wouldest strengthen us with thine Holy Sprite, that we may faithfully travel in our state and vocation without fraude or deceit; and that we may indevour our selves to followe thine holy ordinance, rather than to seke to satisfie our griedie affections or desire to gaine. And if it please thee, O Lord, to prosper our labour, give us a mynde also to help them that have nede, according to that abilitie that thou of thy mercy shalt give us, and knowing that all good things come of thee, graunt that we may humble our selves to our neighbours, and not by any meanes lyfte our selves up above them which have not received so liberal a portion, as of thy mercy thou hast given unto us. And if it please thee to trye and exercise us by greater povertie and nede then our flesh wolde desire, that thou woldest yet, O Lord, graunt us grace to knowe that thou wilt nourish us continually through thy bountiful liberalitie, that we be not so tempted, that we fall into distrust: but that we may paciently waite til thou fill us, not onely with corporal graces and benefites, but chiefly with thine heavenlie and spiritual treasures, to the intent that we may alwayes have more ample.occasion to give thee thankes, and so wholy to rest upon thy mercies. Heare us, $\mathrm{O}$ Lord of mercie, through Jesus Christ thy Sonne our Lord. Amen."

One can see here how easy it would be to quote the first part of the prayer to prove that the Calvinist desired business success as a proof of election-and how foreign that conclusion would be to the whole spirit of the prayer. 
necessity of such regulation was apparent. If the elect were led to walk uprightly without any code being enforced against them, through the mere intervention of the Divine will, the reprobate and the back-slider was under no such obligation. But there was no intention of letting him go his own way. ${ }^{\text {I }}$ So Calvinism naturally developed the most searching discipline that has been known in any church, a discipline of the innerlife as well as the external life of its adherents. This has been apparent from the first:

The Notis, thairfoir, of the trew Kirk of God we beleve, confesse, and avow to be, first, the trew preaching of the word of God.... Secoundlie, The rycht administratioun of the sacramentis of Christ Jesus....Last, Ecclesiasticall discipline uprychtlie ministred, as Godis word prescribed, whairby vice is repressed, and vertew nurished.2

This godly discipline did less than nothing to encourage freedom in the exercise of the commercial spirit. "Oppressioun of the poore by exactionis, deceaving of thame in buyirg or selling be wrang met or measure... do propirlie appertane to the Churche of God, to punische the same as Goddis word commandeth." 3

${ }^{1}$ Cf. an anonymous Calvinist treatise in the Brit. Mus. Add. MSS. 12,515, pencil folio 44: "Micha had an Idol; then ye Beniamites, defiled ye Levites wife to death, and so it would be now, if ye feare of ye Magistrate did not restrayne ye most, for ye feare of GoD doth restrayne but a few $\&$ It were better to liue under ye cruellest Tyrant in ye world then in an Anarchie where there is no gouernement, for then euery one would bee a Tyrant".

Cf. Troeltsch, Protestantism and Progress, pp. 44-5: "The genuine early Protestantism of Lutheranism and Calvinism is, as an organic whole, in spite of its anti-Catholic doctrine of salvation, entirely a Church civilisation like that of the Middle Ages. It claims to regulate State and society, science and education, law, commerce and industry, according to the supernatural standpoint of revelation, and, exactly like the Middle Ages, everywhere subsumes under itself the Lex Naturae as being originally identical with the Law of God".

2 The Scots Confession, in Works of John Knox, 11, p. I 10.

3 The Buke of Discipline, in Works of John Knox, 11, p. 227. 
"Suspicioun of avarice" was deserving of admonition, and might become a reason for excommunication. ${ }^{\mathrm{X}}$

Provision was made for supervising the expenditure of ministers in the Church of Scotland, ${ }^{2}$ and it was only practical considerations which ensured that the supervision was confined to them and not made general. It was only the impossibility of universal enforcement which prevented a similar collectivist scheme of control of expenditure being adopted for general use.

The Scots Kirk recognised that men were not ready to act against their private interests 3 but this made it only the more firm in its discipline. The General Kirk of Edinburgh forced culprits who had exported wheat against the law or lent money at usury to make public repentance. ${ }^{4}$ Sabbatarian considerations led to the prohibition not only of Sunday markets, but also, as a precaution against the desecration of the Sabbath by Sunday travel, of markets held on Saturdays and Mondays. In 1598 Monday was ordered to be a weekly holiday for pastimes and exercise in place of Sunday, as there was a tendency for Sabbathbreaking on the part of those who had no other holiday. The

I The Order of Excommunication and of Public Repentance, in Works of John Knox, vi, pp. 153-4.

${ }_{2}$ The Buke of Discipline, in Works of John Knox, II, p. 236: "Not onlie may the life and maneris of the Ministeris cum under censure and judgement of the Churche, bot also of thair wiffes, children, and familie; judgement must be tackin, that he reather live riotuslie, neather yit avaritiuslie; yea, respect must be had how thay spend the stipend appointed to thair leving. Yf ane reasonabill stypend be appointed, and thay leve avariciuslie, thai must be admonisched to live so as thay resave; for as excesse and superfluitie is nocht tollerabill in ane minister, so is avarice and the cairfull sollicitude of money and geir utterlie to be damned in Christis servandis, and especiallie in those that are fed upoun the charge of the Church".

3 Ibid. p. 252: "And because we knaw the slouthfulnes of men in this behalf, and in any other whiche may not redound to thair privat commoditie...".

4 W. L. Mathieson, Politics and Religion, a Study in Scottish History, I, p. I86. 
courts were not to sit. No household labour was to be required from servants. Scholars and students were to stop work at noon. Cottars, tenants and farmers who owed labour services were to be exempt from work on Mondays. ${ }^{\text {I }}$ There is no sign of the encouragement of the capitalistic spirit here-nor elsewhere in most Church-inspired Scots activities. As Mathieson has well summarised the situation:

A Church which exerted itself to stop the exportation of wheat and the lending of money at interest; which protested on Sabbatarian principles against a Monday market, and through fear of religious contagion against the trade with Portugal and Spain; which required the merchant to close his booth during two forenoons in the week, to make Monday a pastime-day for eschewing of the profanation of the Sabbath, and to observe fasts of a week's duration - such a Church can hardly claim to have promoted the interests of trade... . The religious spirit... was the most serious of all obstacles to industrial progress. ${ }^{2}$

The economic history of Scotland does not very easily support the theory that Scots Calvinism.was a doctrine which favoured the rise of a capitalist organisation of industry. During the whole of the seventeenth century, and for a large part of the eighteenth century Scotland remained poor and backward. Her agriculture was retarded by the continuance of a semi-feudal system, by a lack of drainage which confined cultivation to the hill-sides rather than to the more fertile valleys; no proper manuring or rotation was known, but the old system of infield and outfield persisted and was only dying out in Adam Smith's day. The crafts still retained control of industry to a large extent, and it was necessary to secure the freedom of a city by apprenticeship to a trade to be able to carry on business within; as is well known, but for the protection afforded by the

I I. F. Grant, Social and Economic Development of Scotland before 1603 , p. 554 .

2 W. L. Mathieson, op. cit. I, pp. 202-3. 
University of Glasgow, the work of James Watt might have been stopped owing to his never having served an apprenticeship to any corporation. The trade of the burghs continued to be in the hands of exclusive Merchant Companies-as late as 1662 the Merchant Company of Edinburgh was formed with privileges of exclusive trade. The typical Scots trader remained the pedlar, carrying his wares on his own back, through most of the eighteenth century. These are not the marks of an individualistic and capitalistic country. ${ }^{\mathrm{I}}$ It is remarkable that distinguished economic historians should have advanced such arguments as we have here examined.

One reaches identical results by studying the workings of the Calvinist social system at Geneva. The un-modern system of religiously orientated control was just as typical. The consistory of ministers censured fathers or creditors if they were too harsh. It showed itself without pity for usurers, monopolists and fore-

${ }^{\mathrm{I}}$ It is only in the most indirect of indirect ways that the Scots Church may have had some influence in promoting capitalistic development and the growth of the commercial spirit in Scotland. Scotland was a poor country, and when banks were established-the Bank of Scotland dates from 1695 - they found that they did not secure sufficient business in discounting bills presented to them. So they evolved the system of "cash accounts"- that is to say, they were willing to give overdrafts on generous terms, no collateral being required if two sureties were produced. (See Adam Smith, The Wealth of Nations, II, ch. ii.)

The very poverty of the country, then, stimulated its later development. Such a system could only be practicable when the character and business ability of the borrower-the only real security for repayment-were intimately known. The conditions of Scottish Church life facilitated the acquisition of this knowledge, owing to the strictness of its discipline. Also the educational system which the Scots Kirk had always done its best to forward despite its poverty helped to make this "democratisation" of capital effective. Only in this very indirect way is it possible to connect Scots Calvinism with the rise of Scots business ability. The Church of Scotland, by the encouragement it has given to his intellectual training, may have helped to develop the abilities of the Scot, and by its moral discipline it may in the end have increased his opportunities for securing commercial experience. But it has made no more direct contribution than this towards promoting a "capitalistic spirit" amongst its members. 
stallers. It was merciless against merchants who had in some petty way defrauded their customers-against dealers who had tied string round their coal sacks, against a velvet manufacturer who made his stuff an inch too narrow. It reproved, or severely punished a tailor who charged some English visitors excessive prices, butchers who sold meat above a fixed schedule, a dealer in some unspecified commodity who sold at threepence a quart too much to the needy poor, a surgeon who asked fifty crowns for removing a wen from a patient's forehead. $x$

Some writers, desiring to show the connexion between Calvinism and capitalism, have made much of the fact that a state bank was established at Geneva in 1538. There were good reasons for the establishment of such a bank-financial business was of long standing in the city, and the formation of a bank would have been of service to the city had Geneva been attacked by a hostile power. But the ministers had no intention of permitting too great latitude to this bank. They showed great activity in trying to keep the rate of interest down. They showed no hesitation in attacking even members of the council as extortioners. ${ }^{2}$ They had no mind for Geneva to become a

\section{Choisy, L'étientiente calviniste à Genève au temps de Thẻodore de Beze, pp. 442-3.}

2 Choisy, op. cit. p. 189: "Bèze et ses collegues avaient demandé qu'on n'exigeât que des.intérêts modérés, surtout des pauvres, et ils avaient eu soin de prêcher contre l'usure d'une manière générale, sans désigner particulièrement aucun membre du Petit Conseil. N'ayant rien obtenu une première fois, Théodore de Bèze et Antoine Chauve accusèrent violemment les coupables. Chauve les accabla des épithètes de 'larrons, brigands, loups et tigres'. Il était allé précédemment jusqu'à dire qu'ils étaient dignes d'être attachés à des chaînes de fer pour être sortis de la ville et assommés de pierres".

The ministers even came out best in this quarrel: "Un des premiers magistrats, le syndic Ami Varro, se crût personnellement visé. Il se plaignit amèrement et demanda à se justifier en Conseil des Deux-Cents. Mais il était coupable, et le Petit-Conseil, après avoir entendu ses explications, ne put faire autrement que le condamner à vingt-cinq florins d'amende et à la confiscation d'une somme de cinquante écus qu'il avait prêtée au dix pour cent, dépassant ainsi le taux fixé par les édits". 
financial centre at the expense of her religious purity. ${ }^{\mathrm{I}}$ The godly discipline of Geneva allowed no scope for the greed of gain to enter and place private before public interests or moral rectitude. The reason was that Calvinism abhorred true individualism. ${ }^{2}$ It was the resolute enemy of individualistic movements such as Anabaptism, which proclaimed liberty of conscience. The Calvinist sought an objective truth just as eagerly as the Catholic. He found this truth in the Bible, interpreted, not by the Church of Rome, but by means of the working of the Holy Spirit. It might be asked if the Holy Spirit working in the faithful did not bring the individualism of purely subjective interpretation. It might have done if the Bible were not so simple that all might understand; but, being simple, no doubts as to its interpretation could arise in the hearts of true believers, so that doubts were prompted by the devil and all unorthodoxy was heresy. In a preface to one edition of his Institutes of the Christian Religion, Calvin has stated:

Since we must recognize all truth and sound doctrine to proceed from God; I shall boldly dare to protest in all simplicity what I think of this work, recognizing it to be more God's than mine.... ${ }^{3}$

I Choisy, op. cit. p. 464: "Ils (les ministres) ne condamnent pas le prêt à intérêt comme coupable et illicite en lui-même....Ils ne pensent pas que la parole de Dieu ni les lois civiles et naturelles interdisent une institution comme le change public, établi avec le consentement du peuple. Mais ils ne veulent pas permettre que le taux fixé par les édits scit dépassé, ni surtout que les prêts se fassent au détriment des pauvres. Quand ils voient les abus engendrés par le change ils conseillent de le supprimer au plus tôt, selon la parole du Christ, qui commande d'arracher l'œeil qui est une occasion de chute. Quand ils ont vu l'influence néfaste du développement des opérations commerciales et la formation d'une classe de gens vivant de spéculations, ils sont intervenus pour empêcher l'organisation d'un 'change' qui eût provoqué l'influx des capitaux étrangers, et ils ont exigé le châtiment des conseillers qui se livraient à des pratiques usuraires illicites".

${ }^{2}$ Choisy, op. cit. p. 528: “L'individu appartient à la collectivité et dépend d'elle, avant de s'appartenir à lui-même et d'avoir la libre disposition de sa personne, de ses opinions et de ses actes".

${ }^{3}$ Quoted in G. Lagarde, L'esprit politique de la Réforme, p. 400. Cf. 
Thus Calvin was the chosen vessel of the Lord, a new prophet who spoke the Lord's message. The result of such a belief was a rigidity in doctrine, ${ }^{\mathrm{I}}$ and a rigidity in moral discipline, which followed logically from the Calvinist faith; which carried over the old conceptions of justice in worldly dealings, not necessarily in quite the same form as in the Roman Church, but with precisely the same intentions and with a much more efficient system of ensuring that the rules of just dealing should be obeyed.

To pretend that Calvinism has anywhere made general a capitalistic spirit culled from the Book of Proverbs, while at the same time relieving the practical operation of this spirit from the observances of the Jewish law, is therefore mistaken. The Jewish law was, to the Calvinists, abrogated by the rules of Christian charity. It still remained as a guide, but in its place Calvinism produced a law which was far stricter as regards business and social arrangements. In Scotland at least, this acted as a notable check on economic progress, and on the rise of a rational and practical, in place of a theologically determined, philosophy of business.

It would be interesting to compare this stringent policy of regulation with what might have been expected had the Jesuits and not the Calvinists been in power. ${ }^{2}$ The Jesuits, we are told, another self-estimate quoted in Troeltsch, The Social Teaching of the Christian Churches, p. 882: "So far as I am concerned, my masters, I am quite certain in my conscience that what I have taught and written did not arise out of my own head, but that I have received it from God, and I must stand firmly by it if I am not to be a traitor to the Truth".

I Cf. Choisy, op. cit. p. 527: "Il (le calvinisme) a statué que rien ne doit se faire dans l'Église sans le consentement du peuple, il a mis la Bible, traduit en langue vulgaire, entre les mains des fidèles, il a enseigné aux enfants à lire dans les écoles afin que tous puissent avoir personellement et directement accès à la parole de Dieu, et cependant il a soumis les esprits et les consciences à une interprétation particulière des Écritures comme à la sainte doctrine de Dieu, comme à la dogmatique absolue".

${ }_{2}$ Cf. the estimate of the difference between the Lutheran and Catholic positions made by Troeltsch, The Social Teaching of the Christian Churches, pp. 869-70: "At the present day we must take it for granted that the great 
had a maxim that "there is nothing like business", $\mathbf{r}$ and they certainly acted up to it. When a Jesuit cardinal approves of "sweating", ${ }^{2}$ we know that we have found a religion which has moved far from medieval ideas into the world of laissez-faire. A Jesuit casuist is asked whether an innkeeper may ask a guest to dine on a fast day, knowing that he is issuing an invitation to sin. He answers that it may be taken as a probable opinion that it is lawful, because the innkeeper's primary intention is not to incite to sin, but to make a profit out of the provision of a meal. 3 How does this compare with the prohibition of Saturday and Monday markets in Scotland? A Jesuit affirms that a bankrupt is entitled to retain as much from his creditors as will maintain him decorously-ut decore vivat -and it is explained that this must not be taken as an incitement to "long-firm frauds", for the Jesuits do not favour aggrandisement by injustice, but:

If the casuists have milder sentiments, it is for the good merchants, who have received of their fathers an honourable estate and position, or else who have arrived by good and legitimate ways to a better position than their birth brought them. 4

This is, of course, precisely what is alleged to be an innovation of the Puritans.

economic and social upheavals of the sixteenth century arose independently of the religious movements, and that in them Lutheranism at first adopted an essentially reactionary attitude, whereas the casuistical ethic of Catholicism was in a position to make compromises with them".

I La Morale Pratique des Jésuites (1669), p. ro.

2 V. Brants, writing in the Revue d'Histoire Ecclésiastique, xxı1, p. 88, n. I: “. . . Le card. de Lugo dit que le salaire, qui ne donne pas à l'ouvrier de quoi se nourrir et se vêtir décemment, et a fortiori de quoi entretenir sa famille, n'est pas toujours injuste. Tout cela, traité ainsi incidemment, révèle une coutume conforme".

3 "Concessu est difficilius: concedimus tamen satis probabiliter... quia ministratio illa imo ultronea invitatio non sit a caupone directe alliciendo ad non jejunandum, sed ad lucrum expiscandum." An opinion given by Tambourin, quoted in La Théologie Morale des Jésuites (1659), p. 476. This opinion is in conformity with opinions of Sanchez and Diana.

4 Pirot, Apologie pour les Casuistes. 
All sorts of speculations were allowed by the Jesuits--some even of doubtful morality. The bi-metallic currencies of those days provided various opportunities for their indulgence. It was asked if a servant who had received gold coin from his master to buy goods or to make some payment on his master's behalf might change it for silver at the money-changers, pay in silver coin, and retain the balance for himself. It was agreed that he might, and was not bound to make restitution, though it was a venial sin. ${ }^{\mathrm{I}}$

Wherever the answer to any problem of morals might have an effect on economic life, the Jesuits paid great attention to the consequences their answer would have on trade. For instance, Antwerp had been badly disturbed by the religious troubles, and felt the loss of the foreign merchants very severely. It demanded that heretic merchants should be allowed to conduct business there. Lessius examined the case to see if the prince might in good conscience authorise the return of the English merchants. He recalled to mind the authorisation of the Jews to live in Rome. He pointed out that the English merchants would be few and ignorant of the language, and so would be more likely to be converted to Catholicism by coming to Antwerp than to pervert the Belgians: that the danger was worse for the Belgians who went into heretic countries. So, when one considered the great evils which would result from not allowing the English to return-the fact that the port would be ruined and a rancour be thereby stimulated against the prince; that emigration into heretic lands would take place-it was not only lawful, but incumbent on the prince to allow it. ${ }^{2}$ What a contrast this presents to the prohibition of the Spanish and Portuguese trade to Scotsmen on account of the possibilities of religious contamination!

I An opinion delivered by a Professor of Cases of Conscience at Bourges, censured by the Archbishop of Bourges. Quoted in $\mathrm{La}$ Théologie Morale des Jésuites, p. 244.

2 Quoted in Brants, "Lessius et l'économie sociale"; in La Revue d'Histoire Ecclésiastique, XIII, p. 304. 
The Jesuits not only never tried to secure restrictions on trade such as the Calvinists imposed; they even made their opinions powerful solvents of the restrictions imposed by the state. Governments had a habit of thinking that their decrees were of greater force than Gresham's law. They issued decrees that good and bad money should be valued alike. Asked his opinion, Lessius approved of merchants evading these de-

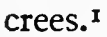

Bail, following the opinions of the Cardinal de Lugo and of Malderus, Bishop of Antwerp, believed that the titles of damnum emergens and lucrum cessans provided sufficient justification for professional money-lending. He complained that the laws of France, which forbade it, were too strict. ${ }^{2}$

Bauni said that it was not reprehensible to enter into contracts in which a higher rate of interest was demanded than the maximum stipulated by royal ordinance, as the debtors entered into them willingly, and for just reasons the rate fixed by ordinance might be exceeded. 3

Pirot said that some methods of receiving profit from a loan are conformable to natural justice, but are forbidden by royal command. For that reason they are not of much use to one who wishes to make a profit from his money. But as they are not against natural law, one is not bound to make restitution if one has employed them. Again he said that the state ordinances against usury were not intended to forbid all loans at interest, but were designed to ensure that the contracts should first be approved by a judge, that he might make sure they did not contain some monstrous injustice. But those who had legitimate titles for lending their money at interest would not sin in lending it without obtaining a judicial order. It is a "probable" opinion that one is not bound to keep a law which is not fulfilling its object; and the aim of this law would cease to operate if, in truth and according to God's

I Brants, loc. cit. pp. 392-4.

2 Bail, De Triplici Examine, p. 426 (quoted in Pirot, op. cit.).

3 Bauni, Somme des Pechez, 5th ed. (1639), pp. 335-6. 
law, there were no usury to be checked in a loan of a particular sort.

It was still the custom for governments to fix maximum rates at which various commodities could be sold. The rise in prices consequent upon the influx of silver from the Americas often made these regulations inconvenient, but they still persisted, and we have seen how merchants were in Geneva excommunicated for disobeying them. The Jesuits, however, treated these maximum rates rather indifferently-a merchant (according to both Escobar and Sanchez) who had a probable opinion that a rate set up by public authority was unjust, might sell with false measures in order to compensate himself, and swear that he had neither exceeded the rate, nor sold with false measures. I The Jesuits-as these examples show-left the way open for an unrestrained individualism in economic affairs. Under pressure from the laity whom they had to humour, they had given their blessing to every operation of the commercial spirit; justifying everything easily by the operation of the twin doctrines of "Probabilism" and of the "Direction of the Intention".

"What other religion," the Bishop of Angelopolis asked with reference to the Jesuits in 1649, "after having declined from its first fervour, has by the writings and the examples of numbers of its Professors brought such a relaxation into the purity of the ancient customs of the Church concerning Usury, the ecclesiastical commands, those of the Decalogue, and the rules of Christian life in general?" They had made the skill of the Church in moral affairs degenerate into probabilism and

I Sanchez, lib. 3, cap. 6, no. 39; Escobar, Tract. I, exam. 3, cap. 7, Praxis ex societ. doctoribus 34 :

"... If it be a probable opinion that the rate fixed for anything is unjust, and if on that account the seller compensates himself for the injustice with false weights or in other ways, he may subsequently, on being questioned by the judge, deny the whole thing on oath, making the mental reservation that he has not acted unjustly." References in La Théologie Morale des Jésuites, p. 3 Io; and Apologie des Lettres Provinciales, lettre xvi. 
become arbitrary. I Yet it is said that Calvinists were especially free in being emancipated from the Jewish law and the regulations of the Catholic Church.

The Jesuits, moreover, practised what they preached. What other order, asked the Bishop of Angelopolis, had carried on a banking business in the Church of God, made loans for profit, ${ }^{2}$ held butcher and other shops in their dwellings? What other religion, he asked, had ever been involved in a bankruptcy, or covered practically all the world with its commerce by sea and land, and with commercial contracts? 3

"There are no merchants so skilful as they", said a Dominican missionary bishop who had seen much of the Jesuits in his diocese. "The Genoese know nothing in comparison with the Jesuits about exchange and re-exchange." It was certain, he said, that they made large profits, because their opinions were very wide, and they traded in anything provided that it paid them; nor was their trade in any degree limited - they trafficked both by land and sea and throughout the world, helping one another in their transactions. 4

If we may believe the tales which are told, the Jesuit foreign missions were not to be distinguished from establishments for commercial exploitation-we are told of their attempts to monopolise the pearl-fisheries in Cochin, 5 of their attempts to get all the trade, all the transport and banking facilities in Carthagena, Quito, Onda, Mompox and, in fact, all South America into their own hands. ${ }^{6}$

In Seville the Jesuit College even underwent a bankruptcy caused by trading losses. The steward of the college borrowed 450,000 ducats at interest. With this he carried on trade. He shipped linens, iron, saffron, cinnamon; he built houses and

I La Théologie Morale des Jésuites, p. 34.

2 The answer to this question is "Many others".

3 La Théologie Morale des Jésuites, p. 36.

${ }^{4}$ La Morale Pratique des Jésuites (1669), pp. 28-9.

5 Ibid. pp. 23 I ff.

6 Ibid. pp. 237 ff. 
mills; bought estates and gardens and flocks. Then the college went bankrupt-in suspicious circumstances, as the account books were removed, and the courts were unable to secure information about the affair. ${ }^{I}$ This raised a clamour through the countryside.

"What will the Dutch merchants say who trade in this province and in the neighbouring coasts, where one hears so often these complaints against the Jesuits?", the Bishop of Angelopolis complained to Innocent X, "What will the Protestant English and Germans say? who boast of preserving such inviolable faith in their contracts, and of proceeding so sincerely and openly in their commerce. Of a truth they will deride and mock the Catholic faith...."2

The religion of the Jesuits was essentially practical. They gained their experience of practical affairs not merely through the confessional but also by actual engagement in business in many cases. They were always informed about commercial needs, and always willing to take them into account in giving opinions in cases of conscience. In this they contrasted violently with the less adaptable Calvinists. The argument that Calvinism relaxed the discipline of the Christian in his conduct of commercial affairs is untrue. Jesuitry relaxed this discipline more

I La Morale Pratique des Jésuites, pp. I88 ff.

${ }_{2}$ La Théologie Morale des Jésuites, pp. 36-7. These examples of the unrestrained speculative element which the Jesuits introduced into their own affairs are admittedly drawn from Jansenist sources, concerned to paint the Jesuits in as dark colours as possible. But there is no reason to suppose that the descriptions of the trading activities of the Jesuits are untrue in any material particular. In the cases where I have quoted Jesuit opinions from Jansenist sources it will be found that $I$ have not allowed any Jansenist exaggerations to enter. It will be found that the opinion is justly attributed to the Jesuits by referring to the writer concerned, or as a rule to such a writer as Escobar. As a rule the opinions which were advanced by the Jesuits seemed so revolutionary and lax to the Jansenists, that, as a matter of fact, they felt no need to exaggerate the Jesuit position as regards commercial affairs. In the few instances in which I have quoted a Jesuit opinion from a Jansenist writer without further confirmation, the opinion is given in a reprint of some official condemnation. 
IO CALVINIST THEOCRACY AND JESUIT CASUISTRY

than any other branch of religion. But this was not because Jesuitry was particularly favourable to the encouragement of the capitalistic spirit. It was because Jesuits were, as the most prominent casuists and confessors, most in contact with the lay world, with its aims and with its difficulties. Everything points to a secular cause of the rise of the spirit of capitalism. 


\section{Chapter V}

\section{PROTESTANT OPINION ON USURY}

If we are to be persuaded that the Protestant Churches introduced an Ethic favourable to the spread of economic rationalism and the spirit of capitalism, it must be shown that they were the first to adopt a rational attitude on the usury question. Free trade in capital is the essence of capitalism. A study of the effects of the Reformation on economic thought is incomplete if it neglects consideration of the place which was taken by doctrines of the use of money, of the investment of capital and its reward, in the social teachings both of the Protestant and Reformed, and of the Catholic Churches. This study is not often made. Some writers have maintained that the Protestants (or the Puritans) from the beginning successfully urged that the employment of capital should be free from restriction. ${ }^{\mathrm{x}}$ But though their instinct is right, that this thesis is of importance, and must be proved to show a necessary connexion between Protestantism and capitalism, their attempted proofs remain unconvincing. Unfortunately the belief is fairly widespread. ${ }^{2}$

The Protestant Reformation was born in a manner which did not promise well for such an immediate development of rational

I Cf. J. Janssen, History of the German People: W. Cunningham, Christianity and Economic Science; The Progress of Capitalism; The Moral Witness of the Church on the Investment of Money. Cunningham suggests that Calvinism attempted no regulation of the economic appetites; that "in so far as a stricter ecclesiastical discipline was aimed at or introduced it had regard to recreation and to immorality of other kinds...". This does not agree with the results of the short study of the operation of the Calvinist discipline in Scotland and Geneva, which was made in the last chapter.

${ }^{2}$ It is very common to meet incidental remarks, such as this, in $\mathrm{Mr} \mathrm{J}$. A. Goris' noteworthy study of Antwerp's golden age (op. cit. p. 578): "Le calvinisme, en élargissant la doctrine scolastique de l'intérêt, justifiait implicitement toutes les spéculations financières". 
thought on the topic of usury. The influential South German firm of the Fuggers, having extended its connexions into the Holy City, had come to act as bankers and financial agents for the Roman Curia. It had attained to considerable importance in this capacity by the beginning of the sixteenth century. In I 501 the King of Hungary entered into an alliance with Alexander VI against the Turks, on payment of an annual pension of 40,000 ducats. The Fuggers were charged with making these payments.

In 1507 the general sale of indulgences to raise money for the new basilica of St Peter's began. Part of the proceeds of the sales of the indulgences had to be remitted to Rome. In 1508 the indulgences sold by the Teutonic Order brought the Pope 10,105 ducats, 5000 of which were transmitted through the agency of the Fuggers. In I 513 they transmitted 2395 ducats and in 1514,2934 ducats as part of the proceeds of the sale of indulgences in Constance. When Leo X tried to stimulate the sale of indulgences in Germany, he again employed the Fuggers as agents for transmitting the money earned.

The Fuggers were not content to play a merely passive part. In 15 I 4 they instigated a scheme for selling indulgences in the dioceses of Magdeburg, Halberstadt and Mainz, which was to be carried on by the new Archbishop of Mainz, Albrecht of Brandenburg. Albrecht had had to pay 30,000 ducats for the episcopal pallium, which he had borrowed very largely from the Fuggers. His total debts to them amounted to 52,286 ducats. The Fuggers were anxious to ensure repayment and proposed that he should secure the right to sell indulgences as a means of securing funds for repayment. The Fuggers were to receive all the proceeds of the sales, remitting half to the Pope and keeping the other half in liquidation of the archbishop's debts. ${ }^{I}$

The sale of these indulgences raised a fierce protest from a German monk who was also a nationalist. As a man of religion, Martin Luther attacked the commercialising of indulgences. As

I Information taken from Ehrenberg, Capital and Finanie in the Days of the Renaissance, and from a review of Schulte, "Die Fugger im Rom", which appeared in Revue d'Histoire Ecclésiastique, v, pp. GI I ff. (1904). 
a mercantilist politician, he steadfastly opposed any developments in international finance which tended to denude Germany of her wealth - that is, of her gold and silver. ${ }^{\text {I The Reformation }}$ occurred as a result of his protests. On the social side Lutheranism remained chiefly a religion inimical to "Fuggerism", to "Fukkcrei", and the attitude of Luther to finance remained the retrograde outlook of a simple peasant's son. As is well known, Luther supported on principle the severest ecclesiastical prohibitions of usury, and even opposed the buying of rents, a practice to which the Catholic Church offered no reproof.

To realise that approval of usury was no part of the Protestant creed one has only to compare the impressive list of prominent reformers with which Bishop Andrewes supported his condemnation of usury, with the comparatively unrepresentative list which Johann Gerhard adduced on the other side. ${ }^{2}$

Protestant literature in condemnation of usury ran in spate in the sixteenth and in part of the seventeenth centuries. Nor was condemnation from the pulpit lacking for the usurer-it

I As an example of the way in which Luther abhorred financial arrangements which denuded Germany of her supplies of the precious metals, see his attack on the Frankfurt fairs in his Von Kaufshandlung und Wucher. They were attacked as the breach through which Germany's money was drained away, "making the whole world rich in order to be beggars".

${ }^{2} \mathrm{Bp}$ Andrewes, in his B.D. dissertation De Usuris (1585), gave the following citations against usury: Calvin, in Praecept. viii; Luther, in Ps.xv; Zwingli, in Luke vi; Erasmus, de Puritate Tabernaculi (Ps. xiv); Melanchthon, Ennar. in Ps. cxii; Camerarius, Catechesi Graece in expos. Praec. viii; Musculus, Observat. in ver. ult. Ps. xv; Heming, in Epist. S. Jacob. cap. v; Aretius, Loco Communi, clxiii. He also supported his contentions with citations from the early fathers, from the schoolmen and from lawyers. It is obvious that he considered that the canonist tradition should be followed. (He was not unusual in this. See Tawney, Religion and the Rise of Capitalism, pp. 84-5, I54 ff. and passim.) Gerhard quoted these authorities against usury restrictions in Book 6 of his Loci Theologici: Aepinus, in Comm. Ps. xv; Chytraeus, in Comm. Deut. xxiii; Heerbrandus and Schnepffius, in Cons. Theol. Bidenb. Decad. r, Consil. 4, and Decad. 6, Consil. 8; D. Hunnius, in 2 Cor. viii; D. Gesnerus, in Ps. xv. 
cannot be placed to the account of Protestantism if the reproofs were ineffective:

The preachers... they crie out continually against all usurers with open mouth and in all their sermons; and yet what availes it? Nothing at al. ${ }^{x}$

It would have taken much more than preaching and pamphleteering to wipe out the practice of usury. "Musculus sayes, that Diuines shall reforme Vsurie when Physicians haue cured the Gout: the sinne and the disease are both incurable." 2 This was not the trivial epigram of a cynic's wit; it was the considered opinion of Wolfgang Musculus, an earnest German minister of great repute and much seriousness.

The practice of taking payment for a loan was common both in Catholic and Protestant countries. Payment was secured most easily by having recourse to some subterfuge, and recourse to subterfuge was common. ${ }^{3}$ Much the same methods of subterfuge were employed by Protestants and Catholics, save that the Catholics often employed complicated contracts such as the triple one combining a partnership with two insurance contracts 4 which were not so common amongst the Protestants. No doubt cruder methods were perforce employed where there were no confessors to advise their charges.

A continuance of this position was more likely to occur in Catholic than in Protestant countries. Time after time Calvin inveighed against the subtleties which permitted virtual usury to be taken. This is where the belief that the Reformation brought a more complacent attitude towards capital seeks its main support. For in Calvin's case it was not mere idle railing. $\mathrm{He}$ set out to construct an exposition of the whole situation based, not on the canonist learning, but on the Bible, intelligently and competently interpreted.

I Wilson, Discourse on Usury (1572), ed. Tawney (1925), p. I8 I.

$=$ Thomas Adams, The Soules Sicknesse (1616), p. 28.

3 See for instance the description of the methods employed by George Stoddard given in H. Hall, Society in the Elizabethan Age.

${ }^{4}$ See the next chapter. 
In 1545 he prepared his famous reply to the questions of Claude de Sachins. I This letter has been the occasion for much ill-considered scoffing, and it is still very often supposed to have introduced a new laxity into the conduct of financial affairs. Calvin's forebodings of misunderstanding have been only too well justified. For he was well aware that he could not answer such a burning question without risk. He foresaw that if he made any concession from the position that usury was altogether urilawful it would be made an occasion for many to claim a complete licence. He would have had fewer qualms had the reply been asked for privately. "But since you ask advice in another's name, I fear lest (by the taking up of some little word) he permit himself much more than I should like." Despite this, however, Calvin felt it his duty to make a bold examination of the issues. "And first," he said, "by no testimony of scripture am I resolved that usuries are altogether condemned."

He examined one by one the texts which were adduced in all condemnations of usury, and gave his reasons why they were not conclusive. His comments took account of the meaning of the Hebrew words which were translated "usury", and of the fact that the real causes of invectives against usury might be accompanying extortion, frauds and circumventions. He pointed out that as far as the prohibition of usury among the Jews was concerned men were now living under a different dispensation from the Old Testament:

For indeed the surroundings of the very place in which the Lord had settled the Jews, as also other circumstances pertained to it, so that it was easy for them to trade with one another without usuries. Our conjuncture to-day does not entirely correspond. So therefore we do not see usuries simply forbidden to us, unless so far as they are repugnant both to justice and charity.

I Professor Hauser has shown conclusively that Claude de Sachins was the enquirer to whom Calvin's reply was addressed. Hauser's brilliant and penetrating study, "Les idées économiques de Calvin", in his Les Débuts $d u$ Capitalisme, must now be considered the chief authority on the subject with which $I$ am dealing in this section of the chapter. 
Next he examined the argument which had been inherited through Ambrose and Jerome from Aristotle, Pecunia non parit pecuniam:

Money does not breed money. What about the sea? What about the dwelling from the hiring of which I receive payment, or is money really born of the roofs and walls? But the land brings forth and by sea is carried what afterwards produces money, and the convenience of an habitation is customarily esteemed as exchangeable with a certain sum of money. And so, if a larger profit may be got out of trade than from the produce of a farm, is he to be tolerated who perchance hires to a farmer a sterile farm, whence he himself receives income and revenue? while he is not to be tolerated, who has taken any profit out of money. And if one acquires a farm with money, does not that money generate other money every year? Whence proceeds the gain of a merchant? from his own activity, diligence and industry. Who doubts that money unemployed is altogether useless? but he who asks a loan of me does not think to have it by him unoccupied after he has received it from me. It is not therefore from the money that the profit grows, but from production. And so the arguments are indeed subtle, and have a certain speciousness, but where they are examined more closely they collapse entirely.

His general conclusion was that the question of usury should be judged, not by any particular Scripture texts, but by the rule of equity, and that it was ridiculous to prefer buying a rent-charge to granting a loan to a farmer for which usury was taken, as it was the actual transaction in itself which was important and not the words in which it was expressed.

So far Calvin does seem to have been making innovations. But the practical importance of these innovations must have been greatly affected by the limitations which he next advanced. "Having laid down the general position," he said, "I shall now come to the exceptions." He asked that special attention be paid to them in order that his opinion should not be misconstrued. "For while I do not condemn usuries in general, I cannot also promiscuously approve all." 
There were altogether seven exceptions. It was wrong to exact usury of the needy. It was wrong to oppress the poor by demanding greater security than they were well able to afford. It was wrong to insert any clause in the loan contract which was contrary to natural justice. It was wrong to take payment for a loan unless the borrower made a gain equal to or greater than that of the lender. It had to be recognised that a practice was not necessarily just because it was in common use. All contracts were illicit which were not more to the advantage of the state than to its disadvantage. It was illicit to take a higher rate than the maximum allowed by the civil power. ${ }^{\mathrm{I}}$

Calvin resumed his discussion of the usury question in several other places, but he did not stray far from this position: that while he did not wish to be understood as being in favour of the practice of usury, as a truthful messenger of the word of God he could not claim that all usury was condemned in God's sight, and as a man of the world, he recognised the necessity for some payment to be made for the use of capital in many commercial transactions.

How should this opinion of Calvin's be interpreted? In many ways it has the appearance of creating an entirely new point of view. So, perhaps, it was, in its determination to look at "facts in themselves, not words". But, examined a little more closely, the novelty is less and the conservatism of the position more apparent. There has not been any marked step towards an individualistic approach to the subject.

It had been evident long before Calvin's day that the question of usury could not be settled by reference to any particular passage of Scripture, unmodified by the context or any other consideration. Obviously, much depended on what passage from the Bible was chosen to support any given contention. Aquinas had laid it down that the usury which is recommended in the Parable of the Talents was meant only in a metaphorical and spiritual sense. ${ }^{2}$

I J. Calvin, De Usuris Responsum (J. Calvini Epistolae et Responsa, Geneva, I6I7 ed., column 488).

${ }_{2}$ Aquinas, Summa Theologiae, ii-ii, qu. 78, art I. 
In practice, Calvin's position (that all usuries were not necessarily to be condemned) had been reached by Catholic teachers. The difference was mainly one of expression. Amongst the Catholics more depended on the formalities of contracts. ${ }^{\text {I }}$ But if the Catholics still believed that all usury was to be condemned (and not all did that) they also agreed that not all contracts were to be condemned which were of usurious appearance.

Calvin had enunciated no radically new considerations in stressing his belief that the application of rules of conduct must be modified in changing worldly conditions. The canonists had all along been making such modifications.

In smashing up the arguments drawn from the technical barrenness of money, Calvin attacked a principle which was supported by the majority of Catholics merely as a lip-service. It was a principle to which the doctrine of interest (of lucrum cessans and damnum emergens) and the doctrine of partnership gave the lie. It was a principle which more than one Catholic theologian of repute had specifically abandoned. ${ }^{2}$

I This was well brought out in the middle of the seventeenth century by the well-known Anglican casuist, ArchbishopSanderson, who suggested that to be on the safe side it would be better to adopt the Catholic view that the form of the contract was of importance: "First, since the nature of Usury is reproachful and the thing itself male coloratum at the best, if not de toto genere unlawful even in regard to the very nature of the Contract itself (as the Roman Casuists generally and without exception of anyone that I know of, and very many Protestant Divines affirm), I think it agreeable to Christian prudence... to avoid all lending upon a Contract formally usurious" (Works of Archbishop Sanderson, ed. by Jacobson, v, p. 132).

2 F. de Mayronis, In Lib. Sentent. Iv, dist. xvi, qu. 3, fo. 204, quoted in Jourdain, Economie Politique au Moyen Age, p. 37 note: "De jure naturali non apparet quod (usura) sit illicita. Una ratio assignatur: Usura est usus aeris. Pecunia sterilis est, et ideo non debet reddere fructum ut plus recipiatur quam mutuatum fuit. Respondeo: Usus rei in politia attenditur ad utilitatem rei publicae: unde in se res non dantur steriles, sed ut cadunt in usu: quo pecunia est multum utilis." (It does not appear that usury is forbidden in accordance with natural law. A single reason is alleged: that usury is the use of money. Money is barren and therefore 
When the various cautions and exceptions introduced by Calvin into his discussion of the usury question are taken into account it is seen that Calvin's position is virtually identical with that of the orthodox Catholics. By limiting the lawful taking of usury to cases where the gain of the borrower is equal to or exceeds that of the lender Calvin had possibly postulated an even stricter condition than was required by the Catholic teaching on partnerships. And throughout Calvin stressed the social duties of the lender-one might not take usury from the needy, or oppress the less wealthy of the borrowers. One had to consider the good of the commonwealth before one's own gain. It is simply untrue to say that Calvin's teaching was of an individualistic nature. He believed that in certain cases it was permissible to take payment for the use of money. But he did not believe that these cases were general:I he perhaps believed they were less general than did contemporary Catholics.

ought not to yield increase so that more should be recovered than was lent. I reply: The use of a thing in society is directed to the advantage of the common-weal; whence things are not given to us sterile by nature, but as they may happen to be used: wherefore money is of great use.) Bernardino of Siena, quoted by Brants, Economie Politique du Moyen-Age, p. 134 n.: "Pecunia... non solum habet rationem simplicis pecuniae vel rei, sed etiam ultra hoc quandam seminalem rationem lucrosi, quam communiter capitale vocamus". (Money not only has the nature of simple money or a thing, but it has also beyond this a certain seminal quality of making gain which we generally call "capital".) According to Brants, op. cit. p. I $35 \mathrm{n}$., the author of the pamphlet $D e U_{\text {suris attributed to Thomas }}$ Aquinas proves in chapters $\mathrm{xi}$, xii and xiv that he knows and appreciates the fecundity of merchant capital.

The virtual abandonment of the Aristotelian principle implicit in the interest doctrine may be seen in Aquinas' exposition in the Summa Theologiae, ii-ii, qu. 62, art. 4: "Ille qui detinet pecuniam creditoris ultra terminum praefixum videtur eum damnificari in toto eo quod lucrari de pecunia posset...". (He who keeps the money of a creditor beyond the appointed date seems to injure him to the extent of the whole gain he might have made by his money....)

I "Vix fieri posse, ut non gravet fratrem, qui usuras exigit." "Foenerari est quaestus certe illiberalis et indignus homine, tam pio quam honesto." (Calvin, Praelect. LIV in E₹echiel, cap. xviii.) 
Even though Calvin's teaching was so little individualistic, his belief in the justification of certain usuries did not secure a rapid adoption amongst Protestant thinkers.

In 1545 the government of Henry VIII of England secured the passage of an Act which permitted the taking of ro per cent. This was a purely secular measure, and such secular measures were general in Catholic countries. Henry VIII's Act was inspired partly by a grave deficiency in the royal exchequer, mainly by a desire to have a law which might possibly be enforced.I But once the law was in operation, it might have been thought that, inspired by Calvin's letter to Claude de Sachins, English Protestants would have supported it as one conformable to the Divine will rather than to Popish superstitions. Yet the normal attitude was very different:

Yea but what shall we then saye by vsurye, whyche is nowe made so lawefull that an offycer yf he would, can not punysh, to make men to leaue it? As concernynge thys matter we haue playne commaundemente in the fiftene of Deutro. And in the fyfte of Math. To lend to hym that nedeth, and wold borowe. And in the syxte of Luke it is playne. Date mutuo, nihil inde sperantes. Lende sayeth Christe, trusting to have no gayn therby. Here we haue two commaundementes, the one is to lende, and the other not to lende for lukar: nowe he that breaketh goddes commaundement must nedes go to the deuyll. So that in breakynge these two commaundementes, here is two wayes for you ryche men to go to the dyuyll: Eyther in lendynge for luker, or els in not lendynge anye thynge at all. Manye of you there be, that whosoeuer sayeth nay, wyll nedes the

I 37 Henry VIII, c. 9, Preamble: "Wheare before this tyme diverse and sondrie Actes, Statutes and Lawes have bene ordeyned had \& made within this Realme for thavoydinge and punyshment of Usurye, beinge a thinge unlaufull, and of other corrupte bargaynes, shyftes and chevaunces, wch Actes Statutes and Lawes ben so obscure and dark in sentences wordes and termes and upon the same soe many doubtes ambiguyties and questions have arisen and growen, \& the same Actes Statutes and Lawes bene of so litle force and effect to thoffenders of the same, but rather hath encouraged them to use the same: For Reformacon' whereof be it enacted...". (Statutes of the Realm, III, p. 996.) 
one of these two wayes. For yf mans lawe do stop vp vsurye, so yat by lendyng thou canst haue no gaynes, than wylte thou the other waye apace, and lend nothyng at all. So shalte thou be suer to come ther away to the deuyll. For than shall no man in no case haue anye vse of thy goods. Therefore neyther the lawe, nor the officer in sufferynge a lytle vsurye, and commaundinge none, doth mayntayne or allow vsurye. But for because you beynge an vsurer wylte nedes to the dyuell, they suffer the to goo such awaye as some commodytye myght come to other by some vse of thy goodes, rather than by stoppynge vp that waye, to dryue the there awaye as no man coulde haue any vse of anye of thy goods.... Thou art fer past all mans cure, either by lawe or punishmente. So wyl I leue the... . I

That was Thomas Lever's manner of disposing of the usury question in I550. A similar explanation of the motives of the I 545 Act was adopted in the preamble of the repeal, which took place in $1552 .{ }^{2}$ The repeal itself (which had been clamoured for by Crowley and the generality of preachers) was the work of a party, which, though the single-mindedness of its motives is very suspect, was at any rate extremely "low Protestant", and prided itself on its evangelical piety.

The legal prohibition of all payment for the use of money remained the law of England till I 57I, although dispensations from the penalties of the law would be granted when the sovereign needed to borrow-whether that sovereign was Catholic Mary ${ }^{3}$ or Protestant Elizabeth.

In I 57I the taking of ro per cent. was once more legalised. Professor Sée has written: "The Anglican Church itself took up a position resolutely hostile to loans at interest and to financial speculations of all sorts; and yet, from I 57 I the govern-

I Thomas Lever, Sermons, 1550 (Arber's Reprint, pp. 44-5).

2 Statutes of the Realm, Iv, pt. I, p. 155 (5 \& 6 Ed. VI, c. 20).

3 E.g. Queen Mary to the Lord Mayor and Aldermen of London, March 17 th, 1558 . She is desirous to borrow 100,000 marks in the city on the security of the crown lands, and will dispense with the act of usury in favour of those who lend to her. (Calendar of State Papers Domestic, I 547-1580, p. 100.) 
ment of the Tudors had to recognise the legitimacy of usury when it did not exceed the rate of 10 per cent. Was this under the influence of the Puritans?"I It was not. The bill was introduced for purely practical reasons. It was thought that the law might be more certainly enforced if a limit were imposed instead of an absolute prohibition, and that extortionate usuries might be the more readily kept down. It was thought that the various forms of usura palliata might be repressed the more easily. ${ }^{2}$ It was a bill supported by the merchants and lawyers, as Wilson's Discourse on Usury, written in I 569 , would lead one to suppose. There is no ground for supposing that the English Puritans were responsible for it-although when Duke William of Bavaria was led to revoke his absolute prohibition in favour of a maximum rate in 1583 it was under the influence of the Jesuits, and he published forms of contract for use by those of his subjects who wished to make profit from lending their money, drawn up by a Jesuit father so as to avoid formal usury. 3

From D'Ewes' all too meagre account of the debate on the second reading, 4 it appears that the chief supporters of the bill were the lawyers Bell and Lovelace, who used typical lawyers' arguments in its support. On the other hand, the chief oppo-

1 H. Sée, "Puritains, Juifs et Capitalisme", in Science et Philosophie de l'Histoire, p. 313 .

2 I3 Eliz. c. 8, Preamble: “ . . . wch said latter Acte (5 \& 6 Ed. VI, c. 20) hathe not done so muche good as was hoped it shoulde, but rather the said Vyce of Usurye, and specially by waye of Sale of Wares and Shiftes of Interestes hathe much more excedingly abounded, ... aswell for that in the said latter Acte there is no provision agaynste such corrupt Shyftes and Sales of Wares, as also for that there is no dyfference of payne forfayture or punyshement uppon the greater or lesser exactions and oppressions by reason of Lones upon Usurie: Bee yt therefore enacted...". Clause vi: "And be yt further enacted, That the sayde Statute... shalbe most largely and strongly construed for the repressing of Usurie, and agaynst all persons that shall offend agaynste the true meaning of the said Statute by any Way or Devyce dyrectly or indyrectly". (Statutes of the Realm, IV, pt. I, P. 542.)

3 B. Duhr, S.J., in Zeitschr. f. kath. Theol. 1900, p. 244.

4 Sir Simonds D'Ewes, Journals of all the Parliaments of the Reign of Queen Elizabeth, pp. 171-4. 
nents of the bill were (besides Dr Wilson, the author of the Discourse) William Fleetwood, the Recorder of London, who was famous for the rigour with which he enforced the laws against vagrants, mass-priests and papists; and Norton, who was a correspondent of Calvin's, translated Calvin's Institutes into English, was a friend of Foxe the martyrologist, and was confined to his own house for a time in 1582 for his disrespectful remarks about the bishops.

Naturally the argument that all usury was not forbidden of God was not missed. It was introduced by Molley, but it was simply incidental to the discussion which took place on a much more worldly plane. It might be a comfort to Parliament to feel that it was not legalising a practice which God forbade, but this was not in itself a positive argument in favour of the introduction of a bill. Moreover, Parliament did not accept this contention, but recorded in the Act that the taking of Io per cent., though henceforth unpunished by the law, was nevertheless distasteful in the eyes of God. Such a compromise should on the face of it acquit the Act of the suspicion of having been procured under Puritan influence.

The influence of all the Churches in England was against the toleration of usury. In the matter of social policy High Churchman approached Calvinist: both claimed for the Church the duty of regulating everyday life in consonance with Divine justice. But on the whole the Puritans were more insistent on this claim, and, more inclined to a belief in disseminating social doctrine from the pulpit, were at any rate more vocal in the struggle against usury and other practices deemed to be covetous. Bishop Andrewes, a High Churchman, made short work of the 157I settlement. He said that those who justify usury on grounds of policy as a means of avoiding worse evils, are no better than Lot, who offered his daughters for prostitution to prevent the exercise of unnatural practices amongst males. He made equally short work of Calvin's opinion (in his commentary on Ezekiel, xviii) that one may take usury from a rich man who can well afford it, without fear of damnation, by pointing 
out that this would justify stealing from a rich man, while it is wrong to steal from either rich or poor. ${ }^{x}$ But Bishop Hall-a Puritan as befitted a Fellow of Emmanuel-also brought his great gift for satire to bear on the tendency to relax usury prohibitions, ${ }^{2}$ and the Puritan, Jeremiah Dyke, barbed his point as sharply as Andrewes when, borrowing from the apologists who, on etymological grounds, confined the prohibition of usury to what was "biting", he added to his denunciations of various covetous practices one of "that foule-fanged sin of vsury, that indeed bites no longer, but is turned Euening wolfe, that swalloweth the bones, and leaues not till the morrow". 3

Why should it be supposed that the Puritan had any predilection for usury? It was the usurer who offended most against the Puritan ideal of the ordered, occupied, useful life, in relying purely on the passage of time. Thomas Adams, "the prose Shakespeare of the Puritans", expressed the grounds of offence very clearly, though it was in one of his excursions into verse:

Each man to heaven his hands for blessing reares:

Only the Vsurer needs not say his prayers.

Blow the Wind East or West, plenty or dearth,

Sickness or health, sit on the face of earth,

$\mathrm{He}$ cares not: Time will bring his money in:

Each day augments his treasure and his sinne.

Be the day red or blacke in Calender,

Common, or holy fits the usurer.

He starues his carcase; and true money's slaue,

Goes with full chests, and thin cheekes to his graue. 4

This was not a type for whom there was any place in the Puritan scheme of life.

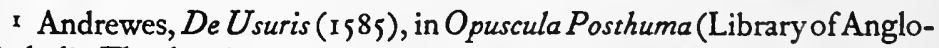
Catholic Theology), pp. 126-7, $134-5$.

2 Heaven upon Earth, Section xxiv. In The Righteous Mammon Hall attacked the maxims, Res valet quanti vendi potest, and Caveat Emptor, showing a pre-occupation with the rules of just conduct in commercial affairs which was very typical of Puritanism.

3 J. Dykes, Counterpoyson against Coutousness (1619), p. 27.

4 Thomas Adams, op. cit. p. 30. 
To realise that English divines did not readily accept Calvin's decision that not all usuries were condemned, one has only to read the list of those writers against usury collected by Blaxton in his English Usurer (1634). To realise that the English Puritans were not generally in favour of usury one has only to note what a large proportion of Blaxton's list were Puritans. ${ }^{\text {T The }}$ change of attitude which took place in Protestant England was not the result of Puritan teaching. Taking a payment for a loan became generally accepted despite the preachers. ${ }^{2}$ The reason for the change in attitude is not far to seek-but it must not be

I Blaxton cites "Archbishop Sands, Bishops Jewel, King, Babington, Downam (the hammer of usurers, Lord Bishop of Derry in Ireland) and Lake; Doctors Pie, Willet, Sclater, Taylor, Smith, Preston, Williams, Web, Sutton, Wilson; Messrs Wilkinson, Smith, Wheatly, Dod, Bolton, Perkins, Adams, Powel, Wilson, Scudder, Rogers of Wetherfield, Rogers of Messing, Rogers of Dedham, Northbrooke, Philips, Robrough, Mosse, Fenton, Dyke, Bayne, Brinsley, Silvester, Quarles, Withers".

Of these Sandys was a conscientious Puritan; so was Jewel; King seemed to have Puritan leanings. Babington was a Puritan. Downham was acceptable to his Ulster diocese because of his staunch Calvinism. Lake was also a Puritan. Dr Pye was a Puritan; so were Willet and Sclater. Thomas Taylor was a Puritan. I have not identified the Dr Smith. John Preston was a Puritan. Williams, later Archbishop of York, was a supporter of the Parliament in the Civil War. Dr Web-possibly George Webb the Quietist. Thomas Sutton was known as the scourge of the Jesuits. Dr Wilson is the well-known author of the discourse; one might say he had Puritan leanings. Mr Wilkinson I have not identified; he is perhaps Robert Wilkinson, a Puritan. Henry Smith was a famous Cambridge Puritan. William Whately, John Dod, Bolton, Perkins and Adams were Puritan divines. Gabriel Powel was described as a "stiff Puritan", but this may not be just. Thomas Wilson was a Puritan. Henry Scudder held Presbyterian views. The three Rogers were all Puritans. John Northbrooke was also probably a Puritan-he wrote against dicing. George Philips was of Puritan leanings. Robrough I have not traced. Mosse and Fenton both appear to have been Calvinists. Dyke, Paul Baynes, John Brinsley, Joshua Sylvester, Francis Quarles, and George Wither were all Puritans. This list of the chief representative writers against usury does not suggest that the Puritans were likely to have worked very hard to secure the legitimisation of the taking of $\mathrm{Io}$ per cent.

${ }^{2}$ It is significant that the collection of Luther's Sermons translated into English in 1578 contained none of his sermons on usury. 
sought in Protestantism. It is simply that from recognition de facto payments for a loan seemed to acquire a recognition as of right:

For people being as Labans sheepe, lead by the eie, doe conceiue as they see. Seeing Vsurie therefore so much practised of all sorts; men are euen thereby without further examination much moued to thinke it lawfull. ${ }^{1}$

The merchants and their friends were all eager to have the taking of ro per cent. justified, for, as the preacher in Wilson's Discourse said, "all the worlde is geeven to harken after theire owne profite. And badde is that Counsell whyche they will refuse to followe when gayne may rise thereof...".2 The movement towards a less stringent view of usury proceeded, not from the Puritans, but from extra-religious sources. 3

In such a world, to exact payment for a loan came to be less generally reprobated. 4 But many of the preachers did not

I Fenton, $A$ Treatise of $U_{\text {sury }}$ (I6I2), III, ch. i.

2 Wilson, op. cit. p. 363 .

3 Such a movement was apparently noticeable in Germany in the first half of the sixteenth century. Wolfgang Musculus used to find business men who justified their dealings from a more or less laissez-faire standpoint. It was said to be common in every man's mouth that: "He yt is willing hath no wrong. I send for no man. I force no man to take money of me. Thei come of their own accord, thei take my money, and do not aske it of any other condicion, but only of vsury: What do I in thys offende. Let them leaue me my money to my selfe, if the dammage of vsurye be so greuous vnto them". To this contention Musculus replied that "these are the sayings not of a christian man, but of a very heathen, yea of him yt hath no mynde of man". (W. Musculus, Of the lawful and vnlawful vsurie amongst Christians. Translated by T. L. (1556?), folio C ii.) As this answer does not appear to probe very deeply into the philosophical problem, perhaps it had little practical effect.

4 See the epistle dedicatory of the translator of Philip Caesar, $A$ general Discourse against the damnable sect of $V$ surers. Translated by Thomas Rogers (1578): "But good Lorde, howe is the worlde chaunged? That whiche Infidels can not abyde, Gospellers allowe. That whiche the Iewes take onelie of straungers, and will not take of their owne Countreemen for shame, that doe Christians take of their deere freindes, and thinke for so 
agree. They were still convinced that usury was a sin, they continued to rail at it. And so the practical man of affairs, like Wilson's lawyer, began to tell them that "it ys not in simple divines to saye what contract is lawfull, and what is not...". ${ }^{\text {I }}$

It was no part of the social policy of any of the Protestant Churches in England to secure the right of taking payment for a loan. English Protestantism, to which the supporters of the Protestant $=$ capitalist equation attach so much importance, was very slow to sanction the fundamental condition of a wholeheartedly capitalistic organisation of society-freedom in the disposal of capital - on which the credit system depends. ${ }^{2}$

doing they deserue greate thankes. That which afore tyme man durst not vse but secretly, that in these daies is commonly vsed. That whiche afore tyme brought men to shame, that in these daies bringeth men to estimation. That whiche afore tyme was vsed of verie fewe, that in these daies is practised almoste of all, and made an occupation...".

${ }^{I}$ It is impossible to read the usury literature of the sixteenth and early seventeenth centuries without agreeing with this attitude to some extent. Some of the divines were a little too simple to meddle with finance. Thomas Bell in his Speculation of $V_{\text {surie }}(1596)$, folios $\mathrm{C}_{4}, \mathrm{D}_{3}$ and $\mathrm{D}_{4}$, was so pleased with his perspicacity in unmasking a fictitious sale that he had to relate the incident twice. Then he made a vain endeavour to elucidate the exchange problem, which included this naive picture of a banker of exchange: "... he cometh to a banker, who partlie of charitie, and partly to get an honest liuing, keepeth seruants at Milan, Lions and Genua, with a stocke of mony in euery place". When merchants had to deal with divines like this, no wonder they got impatient.

Fenton could be just as unpractical. It was often urged that usury was a necessary support of the orphan and the widow. 'Fenton denied it. $\mathrm{He}$ said that God himself provides for them, and so: "Hath God then so many waies bound himselfe by promise to prouide for widoes and orphans; and shall these by vsurie withdraw themselves out of his fatherly prouidence?" (Fenton, Treatise on Vsurie, III, ch. iii.)

This simple trust would appear more fitting to the century which saw Francis gather his brethren round him at the Portiuncula than to the century which saw the English parishes troubled with the evolution of a poor-law system.

${ }^{2}$ Anyone who has read the accounts of Protestantism as a religion for business men might expect to find some confirmation of them in such a work as William Loe's Merchants Manuell ( $1627-8)$. This was dedicated 
Acceptance of the right to take interest made a back-door entry into English Protestantism. It was the work of the merchant and the lawyer, as we may gather from Wilson's Discourse.

Such of the great reformers as supported the lawfulness of usury were in general very half-hearted. Zwingli believed that usury was a natural consequence of private property, but private property was the consequence of sin; that interest was contrary to the laws of God but must be paid when the state sanctioned it. Melanchthon, Aepinus, Calvin, Gesner had none of them progressed far beyond admitting that the cases were different when one exacted usury of the rich and the poor-even Grotius seemed to make only this rather grudging admission. ${ }^{\mathrm{x}}$

Aegidius Hunnius was one of the first to approve of the removal of the ban on usury rather than merely tolerate it. Like Calvin he decided that Biblical texts were beside the point (he said that "Lend, hoping for nothing again" was an ideal counsel, on a par with the.advice to turn the other cheek), and he said that a return over and above one's principal was quite justified "if the payment does not exceed the amount fixed by the laws; if not more than five per cent. is taken; and if it bears some relation to the time and the amount". ${ }^{2}$ It is noteworthy

to the Merchant Adventurers and designed to be used by them as a confessional. It contained not the slightest concession to the spiritus capitalisticus - and a prohibition of usury inserted in the matter arising out of the eighth commandment, "Thou shalt not steal"!

I For Zwingli, see Roscher, Political Economy, II, p. 138, and Tawney, Religion and the Rise of Capitalism, p. 103. For Melanchthon, see Roscher, loc.cit., and Tawney, op. cit. p. 107. For Aepinus see Hauser, Les Débuts du Capitalisme, pp. 65-6. For the others, see Calvin, Praelect. LIv in Ezechicl, cap. xviii; Gesner, Comm. in Ps. xv, and Grotius, Annot. in Vetus et Nov. Test. (in Jer. xv, 10 and Luke vi, 35). Grotius seemed to try to avoid commenting on usury contexts. His general teaching seems to have amounted however to "Non exercendum foenus in egentes, aut eos quos credibile sit foenore in egestatem prolapsos". (Money ought not to be taken from the needy, nor from those who may possibly have been thrust into poverty by the usury.)

2 Aegidius Hunnius (1550-1603), in 2 Cor. viii, 13 (pp. 327-9 of the 1705 edition of his Thesaurus Apostolicos). 
that this is almost exactly the attitude adopted by Luther's adversary, Johann Eck, in 15 I4-Protestant opinion on usury was not more advanced than Catholic!

It was not till the second decade of the seventeenth century that an analysis of the situation comparable in scope and temper with Calvin's letter of 1545 appeared from the pen of any Protestant of note. Then Johann Gerhard published his Loci Theologici, in which the matter was discussed at some length and with a greater resolution than by Calvin. ${ }^{\mathrm{I}}$

In this work Gerhard treated the question with the hand of a master. It was based on Calvin's ideal of considering "things in themselves, not words". He cafne to the conclusion that only payment for a loan at an immoderate rate should be considered usury, and that it was only equitable that loans to merchants should bear interest. He believed Calvin's stipulation that the borrower should gain as well as the lender was unnecessary. In reply to the criticism that he was justifying a practice condemned by the canon law, he did not seek to discredit the guidance of the canon law, but denied that there was any difference of practical importance between his and the Catholic point of view. When all the exceptions to the rule of taking nothing beyond the return of the principal were taken into account, it could not be said that there was a simple prohibition of taking payment for a loan in the canon law. Therefore why pretend that there was? Gerhard had extended Calvin's realistic methods.

His whole-hearted adoption of the liberal side of the usury question must undoubtedly have carried great weight amongst Protestants. Gerhard was (according to the Allgemeine Deutsche Biographie) the "arch-theologian, master and standard dogmatist of Lutheran orthodoxy". ${ }^{2}$ But the days in

I Johann Gerhard, Locorum Theologicorum tomus sextus (4th ed., I639), columns 649-70. The first edition appeared in four volumes between 1610 and 1622 .

2 This does not fit very well with the accepted theory which depicts Lutheranism as an unprogressive, anti-capitalistic form of Protestantism; 
which he wrote were three-quarters of a century after Calvin had written his letter to Claude de Sachins. What is surprising in Gerhard is not the extent of his approval of free trade in capital but the length of time it took any Protestant theologian to go so far. For financial business was carried on in the sixteenth century on quite a large scale, and the Roman Church was not in practice so strict in the application of its usury doctrines as to interfere with the normal growth of investment. The length of time which the generality of Protestants, and more particularly the Puritans, took to accept the position that payment for a loan was lawful, if certain conditions were fulfilled, in place of the theory that it was unlawful, various special cases excepted (which really came to very much the same thing), is a proof of the extraordinarily conservative nature of the Protestant social creed.

It was not till the publication of Ames' De Conscientia in I63 I that any Calvinist pastor followed Gerhard's example and made a thorough review of the usury question, deciding in favour of the liberal side. And it was not till Claude Saumaise (Salmasius) published his De Usuris in I638 that a Calvinist went further than Calvin in his justification of free trade in capital.

Saumaise claimed that usury was permitted by human and divine law, and that discussion should be limited to the rate of interest allowed. He claimed also that the policy of fixed prices for goods was wrong, and that the higgling of the market (the fori ratio) should be allowed to govern them. Even then he found himself opposed by the pastors in the busy commercial kingdom of Holland. Their opposition was so resolute that until 1657 the so-called "table-keepers" were excluded from the

and Calvinism as the pro-capitalistic form. If more attention were paid to such facts it might be understood more easily that neither Lutheranism nor Calvinism was essentially opposed to or in favour of capitalism - that they were both opposed to what they considered to be abuses of capitalism. As I hope to show in the next chapter, the same was true of Catholicism. 
communion in Holland. $\mathrm{x}$ That this could happen in the country where European financial business was at the time largely concentrated is another proof that Calvinism was not identical with economic rationalism.

It cannot be claimed that Protestantism, for good or for ill, brought about any sudden change in the Christian attitude towards usury. It was not an individualising movement which pretended to make the usury question a personal one. It required a very tedious development to make the Calvinists accept the belief that usury regulation was a political affair to be decided by the magistrate rather than by the Church. This attitude came, but it did not come quickly, and may have come almost as early amongst the Catholics as the Protestants. The secularisation of the usury question came because the Churches were not strong enough to retain it as an ecclesiastical matter. The Reformation must have contributed to this by detracting from the authority of the Church. Catholic writers have complained as much. Dr Sanders wrote in his condemnation of usury:

And for as muche as the authoritie of the Church being once called into question, the Scriptures also (whiche were geuen only to the Churche, and are knowen by her tradition and by her vnwritten witnesse) can not keepe their creditte, but are expounded accordinge to euerie mans lust and phantasie; I must also be forced to resort unto natural reason, and thereby to show also that vsurie is of $i$ selfe naught and vniust. ${ }^{2}$

He was hardly correct in suggesting that the way was cleared for such a personal interpretation of Bible teaching, but it is

I Hauser, op. cit. pp. 77-8. W. Roscher, op. cit. I, 334, II, 132; Tawney, Religion and the Rise of Capitalism, p. 238. A book appeared in France in I730 entitled Défense des Contrats et Rentes rachetables des deux côtés communément usités en Hollande. I have not seen the book, but its title suggests that even in the eighteenth century various other contracts were employed in Holland to avoid the taint of usury.

${ }^{2} A$ Briefe Treatise of $V$ surie, made by Nicolas Sander, D. of Diuinitie (I568), fo. 3 . 
true that the Reformation detracted sufficiently from the authority of the Church to favour the rise of a reliance on natural reason-that is to say, the predominance of the conception of natural law. But this conception, though tending to individualism, was not a creation of Protestantism. It was of pagan origin. Protestantism did not aid its spread in any positive manner, but only through the effects of schism, which tended to diminish the influence of the competing principle of the lex divina. It would be futile to speculate what would have been the course of the philosophy of Naturrecht had there been no Reformation. But its growth was essentially independent of Protestantism, and there is no evidence at all that Protestantism ever willingly abdicated any part of the Church's authority over the daily life of a Christian, or that it attempted to exercise its authority in support of different aims than Catholicism. Protestantism is not responsible for the rise of modern opinion on usury and interest. ${ }^{\mathrm{I}}$

I I should like to signalise in connexion with this and with some wider topics, the essay by H. G. Wood on "The Influence of the Reformation on Ideas concerning Wealth and Property", in Property: Its Duties and Rights. Though I differ sometimes from Mr Wood, I consider his general analysis will stand unrefuted. 


\section{Chapter VI}

\section{CATHOLIC OPINION ON USURY}

\section{(I) THE INFLUENCE OF THE JESUITS}

All authors who have tried to trace a connexion between Protestantism and capitalism have made one omission. They have confined their attention to the Protestant side, and entirely neglected the development of Catholic thought. Brentano has criticised this neglect, drawing attention to his Catholic though capitalistic ancestry. Sombart also has contributed curious information gleaned from later canonists which tends to show the necessity for some comparative study of Catholic thought. But nobody seems to have tried to discover how the positions within the Churches really compared during the period when Protestantism is supposed to have been building up the capitalistic mentality. Yet it would not be difficult to hold that the encouragement of economic rationalism was even stronger amongst the Catholics than amongst the Protestants.

The Catholic Church had been moving towards the modern theory of interest in the latter part of the fifteenth century. The theologians, following Cardinal Gaetani (Cajetanus) and the jurists, following Paul de Castro, were practically agreed as to the legitimacy of interest as compensation both for damnum emergens and for lucrum cessans, and they no longer required an interval during which the loan should be entirely free, until the loss occasioned by the lender's non-possession of the money made itself felt. They even claimed to find the same ideas in St Thomas. I The large capitalists of the South German towns such as Augsburg and Nuremberg used to secure capital by accepting deposits bearing a fixed rate of interest. In his

I E. van Roey, "La monnaie d'après Saint Thomas d'Aquin", in La Revue Néo-scolastique (1905), xII," p. 222. 
contemporary chronicle of Augsburg, Clemens Sander said that, during the first quarter of the sixteenth century,

Princes, Counts, nobles, burghers, farmers, serving-men and women have deposited the money they had with Ambrose Hoechstetter, and he has paid them five per cent. Many farmers' boys, who had not more than ro gulden, have given it to him in his business, and thought it was in good hands. For a time he must have paid interest on a million gulden....

... He wasagood Christian and entirely against the Lutherans.... I

This method of securing funds became quite popular.

When in 1574 the association of the Manlichs, consisting of commercial parvenus, declared itself bankrupt with debts to the amount of 700,000 gulden, and in the same year three other merchants failed, the number who were ruined was so great that the Bishop of Augsburg announced from the pulpit that whoever in future should lend money to the trading companies would be excluded from the Holy Communion.. . . In the year 1590 "countless numbers of people were injured and reduced to poverty" in consequence of the suspension of payment by the Augsburg monopolist Conrad Roth....2

It was the common practice in Antwerp in 1532 to trade with money borrowed at rates of interest fixed according to the demand for and supply of accommodation. The Spanish merchants of Antwerp reported to their ecclesiastical advisers in that year that:

It happens sometimes that the merchants have much money at Fair Times, and less at others. There are marked rises and falls, and according as there is little or much money in the hands of the merchants, those who have it give it out at higher or lower rates of interest to those who have need of money and ask for it. The merchants fix the price according to the need which the others have of it,

I Ehrenberg, Capital and Finance in the Days of the Renaissance, p. 152; W. Sombart, Der moderne Kapitalismus, II, 168.

2 J. Janssen, History of the German People, xv, 24. 
and according to the lack or abundance which they see reigning at the fair. The price at which they have fixed it is called bourse price because nobody claims the right to himself of imposing his price on the generality of the bourse, the rendez-vous of the merchants. ${ }^{x}$

Thus the prohibition of usury had broken down in practice at the beginning of the sixteenth century amongst Catholics, and continued during the course of the century to become more and more unreal.

It was Luther, and not his Catholic opponents, who protested against this growth of Fukkerei. Dr Johanr Eck was Luther's most fervent and most celebrated opponent. He might indeed be said to represent Catholicism against the Reformation. Yet he was no enemy of capitalism. He not only supported the great capitalists of his native Upper Germany-he boasted of them. At Nuremberg, and especially at Augsburg, he said, lived "the most celebrated business-men that Christendom has borne for a hundred years, excepting perhaps Cosimo de Medici".2 And he was at some pains to point out that these capitalists were respectable in the eyes of the Church. The large firms of the South German towns were in the habit of employing the contractus trinus, or threefold contract $\bullet$ of partnership, of insurance of the principal, and of insurance against fluctuating returns. This contract was indeed known as the contractus Germanicus, and it was often considered sufficient for the contract to be justified to say that a return of 5 per cent. was secured by means of a deutscher $V$ ertrag without specifying any further details.

In the years I 5 14 to 1516 Johann Eck set out to secure general approbation for this contract. His theses were peddled with varying success round the Universities of Ingolstadt, Bologna, Vienna and Mainz. His thesis de contractu quinque de centum contained a justification of the threefold contract, on condition that the loans were made to merchants-a sensible limitation, but one

I. A. Goris, op. cit. p. 516.

2 E. van Roey, "Le Contractus Germanicus, ou les controverses sur le s pour-cent en Allemagne", in La Revued'Histoire Ecclésiastique, III, p. 9 10. 
in no way unfavourable to capitalism - and it also contained the statement that this contract had been generally employed for more than forty years, and up till then nobody had been refused the Holy Communion on that account; that it had been employed in Augsburg by men and women whose good faith was above suspicion, by a host of honourable citizens who everywhere enjoyed a high esteem, by nunneries, by men learned in the law, so that one might hardly meet an honourable man who had not lent or borrowed on this contract. ${ }^{\text {I Even in }}$ fifteenth-century Germany, then, it had not been difficult to invest capital in manners safe enough to appeal to the ordinary investor. It is, moreover, noticeable that the chief opposition which Eck had to face came, not from theologians concerned with upholding the ecclesiastical prohibition of usury, but from a group of Humanists at Eichstadt, Nuremberg and Augsburg. ${ }^{2}$

The advent of the Reformation brought new questions into the foreground, and for a time the 5 per cent. question was wellnigh silenced. On the Catholic revival in Germany it once more became prominent. A Jesuit historian has described the position:

On one hand stood the sententia communis of the theologians and sundry actual or presumptive decisions; on the other hand the facts of the situation with regard to the taking and giving of 5 per cent. had not stood still in the half century after Eck, but had moved steadily forward. The question became especially disturbing to those, who were then working as the most zealous protagonists for the revival of ecclesiastical life in Germany, the Jesuits. ${ }^{3}$

How did the Jesuits, the great regulators of the practical life, meet this problem? A discussion of this question is the chief object of this chapter.

I Van Roey, loc. cit.p. 909; Duhr, "Die deutschen Jesuiten im 5 ProzentStreit des IGten Jahrhunderts", in Zeitschr. f. kath. Theologie (1900), p. 211 .

2 Van Roey, loc. cit. pp. 91 I-1 2; Duhr, loc. cit. p. 21 I.

3 Duhr, loc. cit. p. 211. 
The first thing which is apparent is that the hands of the Jesuits were more or less forced by the pretensions of their charges. The Jesuits were determined to retain their influence over the laity, and could not afford to strain the allegiance of their followers too far. They were fain to follow the advice which Father Lainez gave to Father Elderen of Augsburg in 1562, at the end of a letter which had explained many ways in which the return over and above the principal might not be usury:

At any rate as far as that is concerned it must be seen that the confessants are not driven to despair and frightened away from confession, and therefore one should also in this follow not the severest opinions, but the general teaching of the theologians. ${ }^{\mathbf{I}}$

If the laity had been content with this, all might have been well within the Jesuit order. But it developed a certain freedom of thought-or obstinacy-and determined not to be dragooned. In I 568, Hoffaeus, then Vice-Provincial of the Upper German Province, wrote to Borgia, who had followed Lainez as General of the Order, full of the difficulties he had to face. $\mathrm{He}$ could not find out how to treat in the confessional those who took 5 per cent. and what advice he was to give to those who maintained they might do so without ignominy, and without being obliged to restitution. "The matter creates such difficulties for us", he said "that in case of its disallowance none of those who take 5 per cent. will confess to us." The confessants said that they had no scruples about taking 5 per cent., since it amounted to a mutual free gift, and the obligation was free and accepted by both sides. The imperial laws and all authorities were favourable.

The difficulties on which Hoffaeus aslred advice were not new. An attempt had already been made to resolve them all by means of an authoritative exposition of the points at issue which had been made by the theologians of the order in Rome. But these difficulties still remained. The exposition had attempted 
to combine prudence in dealing with the commercial classes with a rather non-committal attitude to doctrine. It had desired that usury should only generally be reproved by the preachers who should not enter into particulars, and so should not reprove the taking of 5 per cent. This had not been of much help for the confessional, and had only increased the uneasiness of the priests. The Jesuits were not yet out of a difficulty which their close connexion with affairs made preeminently their own. ${ }^{\mathrm{I}}$

The disinclination of the laity to follow any opinions but its own became more and more apparent. In 1569 we read of the Duke of Bavaria (Albrecht $V$ ) being a little worked up against Father Martin, who had preached against the lawfulness of the 5 per cent. "The Germans", we are told, "will not understand at all just now, that they are not allowed to take 5 per cent., when 7 per cent. to ro per cent. are usual in the Papal States." In 1571 we read of an heir who is restoring the usurious gains of his late father. He restored it all with the exception of 5 per cent., the retention of which he considered lawful, as it was indeed altogether usual. 3 And so matters went on. By I 57 I the laxity of the German Jesuits was so pronounced that the Austrian Provincial complained of its spread into Austria, though he affirmed that up till then these teachings had not been accepted in his province. 4

So serious a problem did the question of 5 per cent. contracts become that the General Congregation of the Jesuits of 1573 had to concern itself in the matter, and a special commission was set up. The decisions of this commission are not particularly interesting - they are mostly concerned with discussing, without adding anything fresh to the discussion, various titles for drawing 5 per cent. There is just one decision which seems to break fresh ground. It was decided that:

Duhr, loc. cit. pp. 212-13.

2 Ibid. p. 214. Letter of Father Georg Schorich.

3 Ibid. p. 215. Letter of Father Dominicus Menginus.

4 Ibid. pp. 215-16. Father Lorenz Maggio to the Vicar-General. 
Whenever two or three theologians defend the same opinion in cases of conscience, the father-confessor may follow them, so long as the general doctrine of the theologians is not opposed thereto. ${ }^{\mathrm{I}}$

This might prove to be one of the beginnings of the doctrine of "probabilism" for which the Jesuits are so notorious. It is not impossible that the adoption and development of this doctrine might be traced to the efforts of the Jesuits to keep up to date in their economic casuistry.

Two years after this the strength of secular control over the economic morality required by the Church became manifest in the diocese of Augsburg. Johann Egolph, the Bishop of Augsburg, had circulated a letter to the clergy and to the faithful of his diocese in March 1575 , condemning usurious practices, and especially condemning certain books which were current in which the 5 per cent. contracts were defended.

His proclamation caused a certain amount of uneasiness, and in the same week the municipal council of Augsburg sent two of its members, Matthew Welser and Jacob Schoenstetter, to interview the bishop and point out that such contracts were customary both in Germany and in other countries, that they were allowed by learned and pious bishops, and brought profits both to the poor and the rich. The bishop's answer to this emphasised that his edict did not touch the customary contracts which were allowed by the magistrates, but only those which were not customary and forbidden. It was then rumoured that the bishop had recalled his edict and explained all 5 per cent. contracts as licit-he had to reply that although some 5 per cent. contracts were certainly allowed, he had not approved all promiscuously. But the bishop's second and third pronouncements were largely to save his face; he had sustained a virtual defeat. ${ }^{2}$

I Ibid. pp. 217-18. This is certainly one of the earliest enunciations of the doctrine of probabilism.

2Ibid.pp. 218-19. The Bishop had published his edict on the advice of Haywood, a Jesuit who had set himself the task of rescuing his order from the hydra of usury. The real significance of the bishop's 
This action of the bishop brought a quick reaction. On June 4th, $^{\text {t } 575}$, Egolph died, and his successor, Marquard, strove just as hard in the opposite direction. His doings may be gleaned from a letter which Father Rosephius wrote to the General from Augsburg on February i Ith, I 576. Apparently the new bishop had so far reversed the policy of his predecessor as to imprison two "learned enough priests" because "they refused absolution in a Fuggerish town to those who entered into 5 per cent. contracts". In the middle of the seventeenth century a minister of St Mary Woolnoth in London found it desirable to relinquish his incumbency on account of the opposition which his unsympathetic attitude to city practices had evoked; but never, one may be sure, has a Protestant Church put such a disciplinary measure into operation for such a cause.

This action of Marquard's is well worthy of remembrance; especially when the views which he expressed on the matter are considered. Rosephius had suggested that it was a matter which should not be approached too hurriedly, but with shrewdness and circumspection. To this the bishop replied that the presumption of the priests had made him very angry, and he was going to make an example of them, lest others should presume in the same way, and load obligations on the people as Catholic doctrine, over which there were still different opinions among the learned, when the situation in Germany required just the opposite.

Rosephius suggested that he might make the evil effects of second and third notices may be found in a memorandum Father Hoffaeus made concerning Haywood in $1580-1$ :

"But not only did he scorn the decisions from Rome; in addition, without the Prior's knowledge he goaded on the late Bishop of Augsburg to condemn the said contract unconditionally in a public proclamation, and to compel the father confessors to deny absolution. The Town Council of Augsburg was embittered to the furthest extent by this order, it sent representatives to the Bishop and so threatened him, that to his shame the Bishop was compelled to withdraw his commands." 
Egolph's edicts an excuse for applying for guidance to Rome. But this Marquard would not do; he even said that he would not obey a Papal command to abolish the contract. He was willing to be martyred for the Catholic faith, but he would never be brought to believe that the 5 per cent. contract offended against God's law; and so he had read and heard enough from learned and cunning men. ${ }^{\mathrm{I}}$

Luther had protested that many illustrious doctors might have another opinion than he, and yet it would not prevent his being right and their being wrong; have we here a Catholic Luther to help forward his Church in finding a place for the commercial classes? The bishop had brought forward the arguments of custom; that it was long considered right that for 20 gulden a rent of I gulden might be bought, that the 5 per cent. contract was usual in Germany not only in the large towns, but in well-nigh all the market-towns and villages; that in Spain, in France and in Italy such contracts were entered into by the clergy, even though forbidden by the positive law. $\mathrm{He}$ said that the matter was so intricate, that if it had to be completely eradicated, the unanimous example of all the princes of Germany would be required, and to attempt it otherwise would only bring unrest and disorder. Marquard ranged himself firmly on the side of the practical men of affairs, and was determined that his priests should do the same. He went so far as to order them to grant absolution to those confessants who had been involved in 5 per cent. contracts; that is to say he intervened in what is really an individual matter in each separate case between confessor and confessant.

The result of Marquard's action was just what one would

I "Wenn, so sagte er, der Papst mir befehlen sollte, den Vertrag abzuschaffen, wuerde ich dies nicht thun, sondern zuerst eine Klarstellung nach Rom senden, welche der hl. Vater ziemlich sicher billigen wuerde. Er sei so gut katholisch, dass er bereit sei, fuer den katholischen Glauben sein Blut zu vergiessen, aber nie werde er glauben, das der 5 Prozent-Vertrag gegen das goettliche Gesetz verstosse, dafuer habe er genug gelesen und von gelehrten und klugen Maennern gehoert." 
have expected-the German laity were quick to take it that the payment of 5 per cent. was justified on the grounds of the productivity of capital and the reward of abstinence, and would not be bothered to seek contracts which avoided the taint of usury; and even pious men were fain to consider that the simple 5 per cent. contract could be justified on a variety of titles. ${ }^{I}$

Such an episode as this shows very clearly that the commercial spirit was working as strongly within the Catholic Church as within the Protestant Churches. Rosephius finished by requesting the General to procure a ruling from the Pope on the attitude they should adopt. ${ }^{2}$

On March I Ith, I 576, the Pope's answer was communicated to the Vice-Provincial, Hoffaeus:

The Pope has answered that those who enter such a contract are not to be absolved by our brethren; but one must take care not to dispute publicly or preach on the matter. ${ }^{3}$

The Pope's reply was not very helpful. It was a virtual abdication of the claims of the Church; it was to warn the Church from interfering too much with business, whilst still not daring to accept the position that payment for loans was allowed. And it did not help the priests in their troubles:

"But a difficulty remains," wrote Rosephius, "if we ought not to and may not absolve those who take 5 per cent., such a contract must be bad in itself. But if it is bad, why is it not allowed publicly to proclaim it as such, to strike fear into others? for here in Augsburg in Nuernberg and Ulm the contract is altogether usual... for what else should the people do, when they see that the old established

I "The obstinate Germans now wish this contract to be considered justified simply on the grounds that I deprive myself of my money for that period and help another with it. Moreover, they will not hear of including a partnership contract or the like, for these people are very suspicious, and they are afraid when so many clauses must be made, and desire the contract of 5 per cent. pure and simple. Even pious people interpret the latter as a partnership contract, as lucrum cessans, as damnum emergens, as the purchase of a rent-charge, etc."
${ }^{2}$ Duhr, loc. cit. pp. $22 \mathrm{I}-3$.
3 Ibid. p. 223. 
usage is supported by the town council, loved by the bishop, and not reproved by the Preacher."I

The Pope's answer had merely increased the difficulties of the situation. The priests were unable to grant absolution as a general rule as Marquard had wished, but no one knew if the Pope really supported the position of the former bishop, or what was the authoritative ruling on the subject. Marcus Fugger was in anxious correspondence with his father-confessor, Father Stotz.

"It is easy to dispute over this matter," he writes, "but you have seen what a Tragedy the bishop ${ }^{2}$ has prepared in this question of the 5 per cent., and the outcome still remains to be seen. If the line of conduct which he laid down must be obeyed, then not only we Fuggers, but all Germany would be in beggary in three years. But neither the Pope nor your company would mind that. It would be altogether good, if you could bring it to the stage that money was also given me without interest, for I owe approximately $1 \frac{1}{2}$ million Gulden for which I must pay 5, 8 even 10 per cent. Against this the King of Spain owes me one million and neither pays me interest nor returns the principal. What ought I to do now?..."3

Other confessants saw good reason for holding an opinion on their own account in the uncertainty of the theologians. Father Theobald Stotz wrote to the General, and mentioned that one confessant had expressly assured him that he did not hold taking 5 per cent. to be a sin; by the Imperial Supreme Court 5 per cent. was allowed amongst men of divers ranks and 8 per cent. amongst merchants, while as it was explained to him, all that the clergy wanted was that no interest should be taken for a loan as such, but amongst merchants and such as lend to merchants it might be justified through a sort of partnership contract-well, he believed such indirectness to be quite unnecessary. Stotz must have told him of the Papal decision that

I Ibid. pp. 227-8. Letter of Rosephius, Superior of Augsburg, to the General, Father Mercurian, May 14 th, 1576.

2 I.e. the former Bishop, Egolph.

3 Duhr, loc. cit. p. 227. 
absolution was to be refused to those who took 5 per cent., for he maintained that he could not submit himself and his children to the Pope in this matter-he was a true follower of Marquard. And he was not alone-he was representative of the Augsburg citizens. The Senate had even publicly entered into opposition to the decrees of the former bishop. And since this sort of usury was now spread far and wide and was generally employed by all classes, Stotz considered it would be desirable for it to be made known on the highest authority what should be understood as usury. For he had heard no one who had not granted usury was a sin, but "by usury they appear only to understand the severest sort of Jewish spoliation" - the quantitative distinction between usury and interest was being drawn.

The uncertainty of the position was made even greater by the ready acceptance in Germany of a book which had just arrived from Venice. Stotz mentioned that he had just been shown a treatise on commerce by Caspar Caballinus which sought to demonstrate that not all usury was forbidden, but only that which violated Christian charity; and that onlyapplied to usury amongst the poor.

"Since this author is a Catholic of no mean reputation," he wrote, "the question must be allowed, what is to be thought about this opinion, wherewith we can answer those who rely upon it, especially as it appears to ground itself on Natural Law and the end of the godly commandment. If we might follow this opinion in practice, we could admit many kinds of Loan-profit among merchants and rich men, and allow those concerned to participate in the benefit of absolution."'I

Rosephius also considered that the advent of Caballinus added gravely to the difficulties which the two bishops and the Pope, by his lack of guidance, had so much increased:

Furthermore, if the large treatise of the celebrated Dr Caballinus, which he has dedicated last year to the Dean of the Apostolic

I Duhr, loc. cit. pp. 225-6. Letter of Father Theob. Stotz to the General, May 7 th, 1576. 
Chamber, is read by the Fuggers and their lawyer compatriots and other townsmen, they will be still further strengthened in their opinion. For he appears to prove his assertion so clearly, that I and such as I are easily unhorsed. We shall not without risk remain loyal to the earlier opinion. Of the town council of this town I know none, be he Protestant or Cathelic, who does not employ the loan contract. Unless I deceive myself, the matter is weighty enough to be considered anew with the utmost care. ${ }^{\mathrm{I}}$

From the description which Stotz has given of this work, it appears that Caballinus had gone at any rate as far as Calvin in denying the complete prohibition of usury. Father Canisius wrote in July 1576 :

In Venice a work in folio about Usury has appeared, whose author, the jurist Caspar Caballinus, characterises the general teaching of the theologians as erroneous, and appears expressly to teach that not every usury is forbidden by godly commandment. We await what the Fathers in Rome think of this book. ${ }^{2}$

Caballinus was a Catholic of high esteem; the dedication of his book was accepted by the Dean of the Apostolic Chambernevertheless, he did not hesitate to throw overboard the traditional teachings of the Catholic theologians. Was the Church of Rome in this matter so very far removed from that of Geneva? Caballinus' arguments were listened to with respect: on July 2ist the General answered the queries of Stotz and Rosephius, regretted that he could not help them out of their difficulties all at once; "someone will have to study Caballinus". 3

The history of the usury question in Germany has so far shown the Jesuits in a very uncertain light: they appeared to be pushed on to a position of not expressing very actively their disapproval of 5 per cent. contracts, but this seemed on the whole to be very much against their wills.

A new attitude now became apparent in the Company. Numbers of the brethren, led by Caspar Haywood, continued

I Duhr, loc. cit. p. 228. Letter of Rosephius to Mercurian, May r $4^{\text {th }}$, 1576.

2 Ibid. p. 228, n.

3 Ibid. p. 228. 
to fulminate against the 5 per cent. contract, but Haywood had now to meet the opposition of all his superiors in his attempts to crush the hydra of usury and so save the Company of Jesus from certain ruin. Haywood's conduct came to be explained away by his bitterness of spirit caused by ill-health; he was called a fanatic, his sanity was called in question. The Company of Jesus was about to throw itself whole-heartedly on to the side of progress - that is to say, the side of individualism, of capitalism.

In November I 580, Haywood had complained to the Papal Nuncio that a young father, Gregory of Valenzia, who upheld the 5 per cent. contract, had converted Hoffaeus (who was now Provincial) and had persuaded the University of Ingolstadt to reconsider its former decision that the taking of 5 per cent. was unlawful. The nuncio had already heard of Jesuits who had advised the Duke of Bavaria that taking 5 per cent. was licit. ${ }^{I}$

Duke William of Bavaria himself gave an account of Hoffaeus' change of front. He wrote that a violent feud had broken out among the learned Jesuits over the 5 per cent. contract, which worried him very much. In this diversity of opinions he had in former years listened to an exposition of Hoffaeus, which condemned the contract expressly and asserted that it had been condemned by the theologians of the Company at Rome on several occasions-particularly in June 1573 . Hoffaeus had advised that a decree should be directed to the judges and magistrates forbidding the sanction of the contract and reserving cognisance of all processes relating to it for his highest court in Munich. The University of Ingolstadt had also given an opinion that the contract was forbidden and invalid, and so Hoffaeus' advice had been accepted. Then Hoffaeus, who had previously often inveighed against the contract, suddenly began to waver, and in the end to approve of the contract, and also of a rent contract terminable on both sides. He had ridden to Ingolstadt, and with the aid of Father Gregory of Valenzia and Father Otto Eisenreich he had pro-

I Duhr, loc. cit. p. 232. 
cured another resolution which overruled the first on all points from the whole body of professors, both theologians and jurists. The result was confusion for everybody. The Jesuits were criticised for having previously advanced a contrary doctrine, for they had condemned this contract all over Germany for quite twenty years, and now in the end they had approved it and supported those whom a short time before they had not deemed even worthy of absolution. ${ }^{\mathrm{I}}$

Hoffaeus was at pains to deny the volte-face; he explained that he had not altered his teaching in the least. He explained his activities in the University of Ingolstadt by saying that the first answer had been supplied by the jurists alone, and all he had done was to secure a fresh discussion in which both theologians and jurists should take part. The ground on which he was believed to have altered his opinion was, according to Hoffaeus, that some, who condemned 5 per cent. contracts indiscriminately, had heard that Hoffaeus also condemned them. And so he did, if it were a mere contract of a loan. But he believed that 5 per cent. could be taken on various other titles. Hearing that he had expressed this opinion, the opponents of the 5 per cent. contract accused him of altering his opinion. As to the differences of opinion among the Jesuits, he says that no Jesuit taught that it was permissible to take 5 per cent. merely as recompense for a loan, but that they only were ignorant of lawful ways of taking 5 per cent. who had not read the text of the contracts, or could not read, or on account of the unfamiliarity of the language could not understand it. As some allowed and others disapproved of these permissible types of contract, they were induced not to raise a clamour about them in Bavaria, for it is free to all to follow a probable opinion. Further, these types of contract were not first tolerated by the Jesuits, but were already supported by older authors. ${ }^{2}$

${ }^{2}$ Ibid. p. 234. Letter of William, Duke of Bavaria, to Father Aquaviva, the new General, April 7 th, 158r. The beginning of the letter had been taken up with detailing disputes between Hoffaeus and Haywood.

${ }^{2}$ Ibid. pp. $235-7$. 
Duhr appears to accept this explanation of Hoffaeus: but it is incredible that some change of opinion had not occurred. Hoffaeus had earlier been full of doubts and difficulties over confessing the takers of 5 per cent.; he was now firmly attached to the principle of widening the scope of the various titles by which ways of securing a return for a loan might be justified. At any rate, whether there was a change of opinion or merely some shifting of emphasis, the official attitude of the Jesuit order was crystallising into one decidedly favourable to the growth of financial business. Duke William had applied to Gregory XIII for a decision, and the Pope had commanded the Jesuit General to let some theologians familiar with the matter reply to the questions propounded-questions which had probably been propounded by Haywood.

Amongst those taking part in the deliberations were Hoffaeus and Gregory of Valenzia. The decision was to this effect: that every taking of interest (Zins) from a real loan contract was forbidden, but that other contracts could be included with the contract of a loan in accordance with which the taking of interest might become lawful. The results of the discussions were set down in a detailed mémoire. ${ }^{\text {I }}$ Six different types of contract usual in Germany were detailed: the contractus trinus was approved, so long as it was entered into with a merchant or manufacturer; a rent contract terminable at the option of the buyer as well as of the seller was also approved. Even a personal rent was not designated as necessarily illicit, though it was considered risky and not generally to be approved. In every case the decisions were to the same effect: interpretations were made lax. ${ }^{2}$

Duke William, as a result of this decision, finally conceded the lawfulness of the rent contract terminable on both sides, and published a range of forms in the German language, according

I Tractatus circa contractum, quinque pro centum, ex communi consensu Patrum, ad id in $4^{a}$ Congr. gen. Soc. Jesu deputatorum confectus mense Aprili 1581.

2 Duhr, loc. cit. pp. 239-42. 
to which one might lawfully conclude a 5 per cent. contract, for the use of his subjects. These forms were the work of Gregory of Valenzia ${ }^{\mathbf{I}}$ - the special mission of the Jesuits in connexion with business affairs was already becoming apparent. Some of the older brethren were distrustful of this state of things, but their complaints only make it more apparent how far the official policy had bent. Father Torres of the Landsberger House complained to the General in 1.586; he said the Landsberger House itself took interest payments (Zinsen) from such contracts; he complained of his lack of success in trying to present his objections to the Provincial (Father Alber); he said that it was clear that the Father Provincial supported the 5 per cent. contract throughout; that he let himself be entirely led by his preconceived opinion in answering Father Torres' questions, that the Rector of the Landsberger House, Father Bonaventura Paradinas, was also on the side of the contract. ${ }^{2}$

According to Father Duhr, it may be assumed that Jesuit orthodoxy was in $\mathbf{1 5 9 5}$ well represented by the three volumes of Theologia Scholastica which Father Gregory of Valenzia published in that year. In this a range of cases were enumerated in which it was allowed to take 5 per cent. without prejudice to the security of the principal. There were the cases of lucrum cessans and damnum emergens; other ways were provided by the probable licity of the contractus trinus, also by the census realis utrimque redimibilis. But still another way remained in which the taking of 5 per cent. was licit: if someone, without thinking of a particular title, intended to receive a profit from the loan, but only by a just and lawful title! 3

I Ibid. p. 244.

${ }^{2}$ Ibid. pp. 244-5.

3 Ibid. pp. 246-7. The "implicit" contract does not appear for the first time in Gregory of Valenzia. It appears to have been first justified by John Major (d. 1550): "Or peuuent ces contrats, dit Major, se faire en deux façons: La première verbalement, \& par paroles formelles \& expresses; l'autre virtuellement $\&$ implicite tantum, comme il arrive quand celuy qui est requis de prester de l'argent intendit expresse omni titulo quo potest, lucrari 6 pro cento $\&$ mutuatarius intendit illi dare lucrum omni ex titulo quo ille intendit accipere". (Bauni, Somme des Pechez-this, however, was 
We are told that

it must be recognised as a service of the Jesuits, that, apart from some Fathers who were bigoted and had no regard for the altered circumstances of the time, most of the decisions of the Generals and the explanations of the Roman theologians tended to this, that a way out could be found in a different setting of contracts, whereby the old usury prohibition remained undisturbed, and at the same time allowance was made for the altered conditions of the times and the generally prevailing custom. ${ }^{\mathrm{T}}$

If that is the considered opinion of one of the most eminent Jesuit historians, there should be little objection to looking among the Jesuits for religious encouragement of the commercial spirit.

Somewhat nearer the times we are considering, a famous book characterised the work of the Jesuits as follows:

The Jesuits, who profess an accommodating theology and try to indulge the passions and desires of men as far as they can, have worked hard on this matter of usury to find subtleties and means of palliating and excusing it, in order to grant freedom to exercise it without scruple and in security of conscience to those who wish to follow their maxims. ${ }^{2}$

This description of the activities of the Jesuits is not unjust. In place of usury they substituted various other means of receiving a return for a loan. We have seen them doing it in Germany. They developed the triple contract and the rent contract instead. The case of the triple contract was fairly simple. It was permissible to enter a contract of partnership with one man, to insure against loss of the principal with

condemned by the Paris Theological Faculty: "Elle porte manifestement à l'usure, \& n'est pas conforme à l'opinion de Major".)

But Gerson had long ago said that: "Omnis fere contractus usurarius ex genere potest per piam intentionem in opus pietatis transferri". (V. Brants, Economie Politique du Moyen-Age, P. I 5 I.)

I Duhr, loc. cit. p. 248.

2 La Morale des Jésuites (';667), III, p. 352. 
another, to insure against fluctuating returns with a third. Was it permissible to enter all three contracts with the same person? The only doubt which assailed the commission of $158 \mathrm{I}$ was whether a contract of insurance of the principal could be added to a combination of the other two; for the first combination was approved as a matter certain. The commission approved the addition of the third contract as a matter probable in agreement with Navarrus and other theologians. I Not all Jesuit confessors were themselves in favour of the contractus trinus, but as a probable opinion was sufficient to justify an action the adoption of the Jesuit casuistry meant that the contract was always approved. ${ }^{2}$

Though the Jansenists might protest against the triple contract, and dismiss it as a mere fictitious device, ${ }^{3}$ the Jesuits had no hesitation in supporting it against these attacks. It is not palliating usury, said Pirot: to palliate usury one must feign a legitimate contract, such as the pretended contracts used in dry exchange, or in fictitious sales. But here the three contracts are all real and effective, not feigned. ${ }^{4}$ From the formal point of view Pirot was right.

The Jesuits, in their attempts to "profess an accommodating theology", were occasionally thwarted by some of the less progressive Popes making pronouncements in favour of

I Duhr. loc. cit. pp. 240-I.

2 The extent to which the doctrine of probabilism was carried may be seen by the following quotation from the Spanish Jesuit, Escobar: "If I have a proper intention of seeking a probable opinion in my favour and am disposed in firmness of spirit to do nothing contrary to the probable dictates of conscience, I may indeed lawfully visit different counsellors until I find one who replies as I wish". For other references of similar import see La Théologie Morale des Jésuites (I659), p. 307.

3 E.g. Pascal, Lettres Provinciales, viII. Cf. Apologie des Provinciales, II (3rd part), lettre xiv: "Quoi donc! mon R.P. osez-vous dire que le simple proposition d'un contrat de société que l'on n'a pas la moindre envie de faire, suffit à celui qui prête pour tirer un profit considérable de son argent, sans risquer le sort principal, \& sans commettre néanmoins la moindre usure...?"”

4 Pirot, Apologie pour les Casuistes (1657). 
stricter ways. Sixtus V's Bull Detestabilis of 1586 , which forbade the triple contract, was such a pronouncement. In these cases the only thing to do was to see if the Papal command might not be ignored. The Bull had not been promulgated in Germany. The German Provincial asked if he really had to act upon it. I It was decided that it might be ignored.2

An example of the same sort of thing appears in the Jesuit treatment of rent contracts. The buying and selling of rents had been allowed by the Decretals of Martin V and Callixtus III, but only upon fairly stringent conditions. For instance, the rent had to be settled on a farm or some productive asset, and in the event of the failure of that asset the rent should cease. The rent might be redeemed at the option of the seller, but the buyer might not force the seller to redeem it. That is to say, to lend on the "rent" title was to make a permanent alienation of the principal, there was no provision for its repayment; and in the event of the wasting of the asset on which the rent was founded, the debt was discharged, not being secured on the general assets of the debtor.

But custom had notably enlarged on this position: by the addition of different clauses the rent charge had been assimilated to the contractus trinus. Pius V, wishing to return to the

I Duhr, loc. cit. p. 246, n.: "Father Alber wrote to the General from Innsbrueck on the tenth of April 1587, that they were surprised by the Bull of Sixtus $V$ against the partnership contract with the double insurance "ontract added, since the theologians at Rome had completely approved of it in the Fourth General Congregation in agreement with Navarrus and Medina, and it had consequently been recommended in Germany by the Jesuits. Would the Father General write at once to say what attitude was being taken in Rome in regard to the Bull? whether it had perhaps been, as many wished, revoked again in Rome, since it had appeared six months ago already but had not yet reached Germany".

2 R. Arsedekin, Theologia Tripartita Universa, ii-ii, c. v: “...The Bull of Pope Sixtus does not prohibit this contract as unlawful in natural law, but only as likely to cause scandal and through presumption of covert usury, which does not apply if the contracts mentioned are made in truth and sincerity and not fictitiously. As a result, in Germany and Belgium, it is held by many not to have been received". 
canonical position, published the Bull Cum Onus to this effect in 1559 . This was a challenge to the Jesuits, and they accepted it boldly. The commission on usury questions of 1573 included in its decisions the following:

On a productive object it is allowed to establish rents terminable on either side, but where the Bull of Pius $V$ is in force, the buyer may not pledge the seller to repurchase. ${ }^{\mathrm{I}}$

This decision means that the Bull of Pius $\mathrm{V}$ was also regarded as having only a limited applicability. It was suggested that a Papal Bull was only to be enforced where it had been formally received, and the Jesuits in each country were at pains to point out that the Bull had not been received there. Lessius wrote that it was not in force in Belgium, nor in Germany nor France; the. official explanation from Rome was that "the Constitution of Pius V is not in force in Germany-apparently only in the Papal states and in a few other parts of Italy".2

The Jesuit commission of $158 \mathrm{I}$ also discussed the rent question. It announced that there were two difficulties-one, the question of whether a rent contract terminable at the option of the buyer as well as of the seller was allowed: the second, whether it was allowable to add an assurance contract by which the seller undertook all the risk and the principal was assured to the buyer, even in the case of the loss of the asset on which the rent was constituted. Both these questions were answered in the affirmative, following Medina and other authorities. The contracts were only invalid where there was a contrary positive law.3 This finding was submitted to the theologians of the Upper German Province at Dilligen in 1586 for interpretation. It was then decided that the rent contract terminable on either side was allowed in all the provinces of the Empire in which a prohibitory state law was not in force. Moreover, that such a

I Duhr, loc. cit. p. 217.

2 Van Roey in La Revue d'Histoire Ecclésiastique, III, p. 930, n.; Duhr, loc. cit. p. 244 .

3 Duhr, loc. cit. p. 24I. 
law did not exist, both in the lands in which it was never made known, and in which contrary custom was more general, despite the fact that the law had been promulgated! Both or at least one of these conditions applied in most provinces of Germany.I Gregory of Valenzia, in his Theologia Scholastica, went even further: the rent contract redeemable on both sides was merely to be avoided in foro externo where Pius V's prohibition or that of the Emperor Charles V of 1548 were in operation, and elsewhere it was completely allowed; its natural lawfulness was not affected by the Papal prohibition. ${ }^{2}$

The complete manner in which the Bull of Pius V came to be ignored becomes very evident in the celebrated answer of Father Daniel to the Letters of Pascal.

"A little while ago", said Cléandre, "I embarrassed very much a doctor of the strict morality by a difficulty which I propounded to him about contracts of establishing rent-charges. It is certain, I said to him, that one can only establish the justice of this type of contract by probable reasons. It has only been in use, or at least authorised, for two or three centuries: it was at first regarded by many doctors as a usurious contract...."

Eudoxe objected that it was approved by Martin V and Callixtus III; Cléandre replied that the strict doctor had indeed made the same response. But Cléandre had pushed his argument further-he had pointed out that if the contract was against natural justice, the Pope could not make it just; that many held that the authority of the Pope was not sufficient to make an opinion sure which before had been doubtful. And further than this, the approval of Martin and Callixtus was subject to severe limitations.

"But in France one does not keep to these conditions in the least: he who receives the capitalization of the rent (constitution de rente) obliges his property in general and his own person.... It is evident therefore that the most sure conduct is not to have, not to make, not

I Duhr, loc. cit. p. 245.

2 Ibid. p. 247. 
to receive these sorts of settlements at all, at least in the way in which they are done in France.... It is manifest that there all follow the probable and less certain. I assure you", added Cléandre, "that my man was taken aback, and did not know what to reply to me."x

We see, then, that the Jesuits had introduced a greater degree of liberty in assuming individual opinions into the Catholic Church, by their doctrine of probabilism, than was to be found in the Reformed Churches. The authority of the Pope did not diminish this freedom, for the Pope's authority was necessarily obeyed only when he had expressed himself in a Bull and not in an Encyclical. Even then the Bull had to be received for it to become binding. This liberty of opinion was especially enjoyed over questions of business conduct.

Besides the rent charge and the triple contract there were "many legitimate titles, which give us the right of drawing a profit from money which we lend...".2 Lessius, for example, had.given it as his opinion that the only justification needed for taking interest on the title of lucrum cessans was furnished by the very motive of that title's existence. The existence of the title presupposed a real desire to make profits which might provide the occasion of a pact; and calculation might be made beforehand as to the indemnity to be made for going without the satisfaction of this desire. Lucrum cessans, therefore, was more than a title which might be employed in particular instances if it could be shown that a profit had been missed. Lessius had admitted the general permissibility of interest as used to-day. He claimed that his opinion was widespread. 3

It would be tedious and unprofitable to attempt to analyse

I Entretiens de Cléandre et d'Eudoxe, Entr. iv.

${ }^{2}$ Pirot, Apologie pour les Casuistes, p. 98.

3 V. Brants, "Lessius et l'Économie Politique et Sociale", in La Revue d'Histoire Ecclésiastique, xIII, p. 307. The argument is taken from Lessius' De Justitia (1612). Brants asserts that the opinion expressed was not very widespread, but was becoming so "under the pressure of the spirit of gain". 
all the possible titles. I It is not so unprofitable, however, to discover the Jesuits' reasons for evolving or supporting the titles. For they knew well that they were merely cloaking loans at interest with other contracts-they often found it more convenient to talk of the investment as a loan, even when it was formally something else. ${ }^{2}$

The Jesuits began by recommending the use of the various 5 per cent. contracts only in the last resort. At first they attempted to wean their confessants from the desire to make money breed money; but if they failed they would then explain ways of allowing it to breed without committing usury. The commission of $158 \mathrm{I}$ had approved the contractus trinus rather half-heartedly; it had only said that the contract should not be condemned unconditionally, and those who had employed it should not be forced to make restitution. 3 The commission of I 586 had suggested that the rent contract redeemable on either side should be recommended only to those who could not otherwise be weaned from usury ${ }^{4}$-which means that they should be weaned from "usury" by insisting that some real property should be mortgaged and calling it something else. Even Gregory of Valenzia had written that "in general the taking of 5 per cent. is not to be advised, but if anyone persists in it, it is better to explain and recommend to him one of the ways given above". 5

After a while the impression that these contracts were conceded only on account of the hardness of heart of the investor in bonds died away. Practical reasons for their adoption were more stressed; it seemed that an extension of their use should be made on political grounds. Lessius was employed to write

I Pascal loaded the dice against the Jesuits in his Letters, intellectually if not morally. For instance, the flagrant Mohatra contract in which a borrower sold for cash goods he did not possess, but at the same time bought them on credit for a higher price from the same dealer, was very rarely recommended by the Jesuit casuists.

2 Thus Bauni wrote: "Tous les contrats d'argent presté, ainsi en parlons nous, prenant toujours le mot de preste improprement $\&$ au sens que nous avons dit".

4 Ibid. p. 246.

3 Duhr, loc. cit. pp. 240-I.

5 Ibid. p. 247. 
a pamphlet on the Montes Pietatis in order to strengthen the hands of the Netherlands government in the execution of some scheme which was supposed to be in the public interest. In this pamphlet he explained that the triple contract had been ardently discussed and that many condemned it. But if one had followed their opinion it would have been to the detriment of the king and the people. Without it the war finances would have necessitated much more onerous procedures. As it was a duty to procure the public good, it was suitable to employ a probable opinion to that end.I Lessius again approved of the contractus trinus on utilitarian grounds in his De Justitia. ${ }^{2}$

Father Daniel also stressed utilitarian reasons for allowing such contracts, and wrote on the folly of forbidding them through a reliance on general maxims, the application of which was impossible in a variety of circumstances:

But in a word, as soon as a doctrine plants so universal a disorder and trouble in the affairs of life, it is a moral demonstration that it is false. It is against the order of Providence, and consequently against the eternal verities, of which our reason and common sense are but expressions, which make up a part of the rules of conduct which God has given us. That is why it has had so short a duration, and that is the lot of all outré opinions. 3

I V. Brants, "Lessius et l'Économie Politique et Sociale", in La Revue d'Histoire Ecclésiastique, xiII, p. 304.

2 Brants, loc. cit. p. 3 II. This is his description of the workings of Lessius' thought: "On le voit, ce n'est pas le point de vue de la stricte licéité, mais l'opportunité législative, le bien commun qui est en cause ici. Or il estime que si on défend ce genre de contrat, l'effet sera tout autre. Les gens, dit-il, qui ne trouvent pas des rentes à vendre, ne sauront comment garantir leur capital honnêtement et vont se livrer à des pratiques nettement usuraires, interdites et malhonnêtes; on enlevera aussi aux braves gens le moyen d'assurer le placement de leurs filles, les études de leurs fils, il y aura toutes sortes d'inconvénients. On voit bien apparaître ici le docteur de la vie pratique, qui ne veut pas multiplier les interdictions légales".

3 Entretiens de Cleandre et d'Eudoxe, Entr. Iv. The opinion which is given as having had only a short duration was that the most certain opinion must be followed in the matter of rent charges; this condemned their sale entirely. 
Pirot proceeded to demonstrate that it was expedient to use the methods of the casuists, by employing the same sort of argument. Those who are opposed to the Jesuits, he said, are overthrowing charity in the name of charity and gratuitous lending, "especially as those who have money, being frightened by this opinion, and fearing to be damned if they draw profit from their money except by constitutions of rents, keep it locked up in their chests and in this way hinder commerceout of which the poor earn a living". I For these practical reasons, then, the Jesuits turned from a mere tolerance to a positive encouragement of the use of the different loan contracts to serve the spirit of gain:

One would oblige not a few people, therefore, if, keeping clear of these evil effects, and at the same time of the sin which is caused by it, one gave them the means of drawing as much and perhaps more profit from their money, by some good and lawful employment, than one does by usury. It is this with which we end our chapter: the form in which it is considered that all may do it without sin will close this discourse...2

Pirot represents Jesuit doctrines very admirably. He began his discussion of the topics of lending and borrowing by saying that "the men of property who would desire to draw some honest profit from their money are much embarrassed by the diversity of the sentiments of the theologians". To reassure them, therefore, he made an analysis of Bail's De Triplici Examine, which had "solidly treated these matters", and decided them in favour of the constructions likely to be favoured by capital owners. He then gave his own opinions. He said that a "theologian who only stops at reasons of theology may advise one who possesses some money to draw an honest profit from it". He was willing to advise them how to do itto say exactly "ce qui suffit pour mettre en seureté de conscience

I Pirot, op. cit. p. II r.

2 Bauni, op. cit., quoted from a condemnation made by the Paris Theological faculty and published in La Théologie Morale des Jésuites. 
ceux qui veulent tirer du profit de leur argent". He marked his approval of the liberal school amongst the Calvinists; he praised the writings of du Moulin, d'Argentray, Louet and Saumaise very highly, and recommended the Jansenists to read what a good friend of theirs (Saumaise) had to say on the desirability of permitting loans at interest. ${ }^{\mathrm{I}}$

Is there any justification, then, for suggesting that Calvinism introduced a new outlook on the investment of money? The Jesuit doctrine of the direction of the intention, by which one and the same contract might be lawful or usurious according to the intentions of the parties, made it impossible to distinguish unlawful usury, and in that way justified all payments for a loan. The Jesuits accepted the arguments of Calvin against the sterility of money. ${ }^{2}$ They went so far as to justify payment of interest on the individualistic grounds that a free contract was in itself just. ${ }^{3}$ And the fact that the chief motive for entering a

I Pirot, loc. cit. passim.

2 Lessius, De Justitia, lib. II, c. 20, dub. 11, quoted by Brants, "Lessius et l'Économie Politique et Sociale", in La Revue d'Histoire Ecclésiastique, xIII: "Pecunia illa...quatenus subest industriae tuae ad lucrum ex ea faciendum, pluris tibi valet quam ipsa per se considerata, est enim velut semen fecundum lucri per industriam in quo lucrum ipsum virtute continetur". (That money... in so far as it provides an opportunity of gain being made from it through your industry, is worth more to you than it is considered in itself, for it is, as it were, a fertile source of gain through industry, in which the gain itself is virtually contained.) Bail also wrote (according to Pirot) that money takes on the nature of the things it buys. Therefore it is usury to lend to a poor man for him to buy the necessities of life and expect a payment for the loan, but it is not usury if it is used in business or for the purchase of property.

3 Bauni said that it is lawful to hope that a borrower would make a return out of gratitude; it is lawful, therefore, to make a pact beforehand that he should. For there is no evil in making a contract to secure all that it is permitted to hope for, to give and to accept. A Professor of Cases of Conscience at Bourges went so far as to say that a payment was not usury "if the pacted addition neither weighs upon nor injures the borrower when he receives the obligation or executes it; because no injury is done to the borrower, nor does he seem to undertake the obligation unwillingly" (La Théologie Morale des Jésuites, p. 244). 
contract was the desire for gain did not make the intention bad. $\mathrm{I}$ The fact that the Jesuits did not take the step of denouncing or casting aside all usury restrictions does not prove that they were less advanced than the Protestants. It only proves that the Jesuits were satisfied that the contracts which had been evolved to evade the usury prohibition met all reasonable needs. As Pirot said, the rent charge and the triple contract were all that was necessary, for in practice nobody would lend to those who could not offer sufficient security - and if the security offered was a hereditament or property of some sort a rent could be settled on it, while if the security offered was the ownership of some profitable business, a triple contract of partnership and insurance would suffice.

\section{(II) SUMMARY OF RELATIONS BETWEEN} PROTESTANT AND CATHOLIC TEACHING

\section{ON ECONOMIC AFFAIRS}

Our studies so far have not shown that the encouragement of the spirit of capitalism has been the exclusive work of any one section of Christians. The development of Protestant thought on usury was certainly no more significant than the development of Catholic thought on rent charges and threefold contracts, and on implicit contracts of which the legitimacy was secured by good intentions. The attempts at strict regulation of the economic life made by the Calvinist churches were definite hindrances to capitalistic development and the spread of capitalistic ideas which formed a strong contrast to the comfortable and accommodating religion of the Jesuits.

These are matters with which the sociological school has not dealt. But a comparative study of Protestant and Catholic

I "It is permitted to hope for and desire profit from a loan, given with goodwill and accepted with gratitude, not only as a secondary consideration, but also as the first and principal one." (A quotation from Longuet, in La Théologie Morale des Jesuites, p. 163.) 
thought also disposes of many of the chief arguments which this school does employ. It reduces considerably, for instance, the importance which can be given exclusively to the Puritan doctrine of the "calling" - a doctrine which studied by itself, however, proves to have been by no means always an encouragement to capitalism.

It makes some very favourite arguments drawn from the writings of Benjamin Franklin of small account. Weber had drawn much of his inspiration from reading Franklin. He believed that Franklin's insistence that Time is Money and not to be wasted, that Honesty is the Best Policy, his love of detail and exact reckoning, were the apotheosis of Puritan doctrines of worldly prudence. He said that Franklin's strict avoidance of time- and money-wasting vanities were typical fruits of his Puritan upbringing. ${ }^{\mathrm{I}}$ But are they characteristic of any one religious creed? Werner Sombart has suggested that these writings are only an echo of fourteenth- and fifteenth-century Florentines, such as Leon Battista Alberti, Agnolo Pandolfini, Antonio and Lorenzo da Vinci, and that the wealth of the burghers of Florence was built up with parsimony and industry on just such a scheme of life as Franklin's. ${ }^{2}$ Nobody could build up a theory to connect Puritanism and capitalism on a basis of studying these Florentine writings, or not dissimilar ones produced by the Roman moralists. Weber had denied the validity of this criticism. He asserts that Sombart has been guilty of mistranslating or misunderstanding the Florentine authors. 3 Whether he has or not-a controversial matter into which there is no present need to enquire4-it may be noted that the ordering of one's life for the pursuit of gain, which was not enjoyed, through the exercise of parsimony, was

I Weber, op. cit. pp. 3 I ff. and passim (Engl. trans. especially pp. 48 ff.).

2 W. Sombart, Quintessence of Capitalism (Engl. trans.), ch. vii.

3 Weber, loc, cit. p. 38, n. I (Engl. trans. pp. 194 ff.).

4 It is noteworthy, however, that Sombart repeats his statements in the latest edition of his Der moderne Kapitalismus, II, Pp. $30 \mathrm{ff}$. He evidently feels he has nothing to retract. 
sufficiently established before Luther's doctrine of the "calling" was evolved for Erasmus to lampoon it in his colloquy Opulentia sordida. I The victim of this attack is supposed to have been one of Erasmus's Italian hosts. It is, moreover, certain that Franklin's advice about the careful ordering of one's daily life and avoidance of unnecessary indulgence were also commonplaces in the writings of seventeenth- and eighteenth-century Catholics. The Christian, said Father Tronson, "does not pluck flowers, or wear any, simply for the pleasure of flaunting them"- "he does not waste his time at a door or window looking at the passers-by". ${ }^{2}$

Father Crasset believed that it was following divine precept to conduct one's everyday life with a rigorous adhesion to plan:

Prescribe for yourself an order in the day's routine, which you keep inviolable, unless you are hindered by a higher command which forces you to depart from it. Regulate the time of your resting, your eating, your study and diversion! In Heaven one's whole life is orderly; begin a life which you will continue in eternity; it will be more acceptable to God, more agreeable for your family, if you have one, and more advantageous for your salvation. ${ }^{3}$

Father Croiset's advice was also not very dissimilar from Franklin's:

I Gilbertus has described the lack of amenities in the rich Antronius' house.

"Jacobus. But didn't Antronius meanwhile get disgusted with these conditions?

"Gilbertus. Save for gain, nothing was sweet to him, brought up in niggardliness as he was. He spent his time anywhere rather than at home, and in everything he did he had an eye to the main chance. But you know that city is money-grubbing (Mercurialem) before all others. That celebrated painter esteemed it a matter for regret if a day went past without a line; Antronius was far more distressed if a day passed by without gain. And if by any chance this happened, he sought to make it good at home (Quod si quando evenisset, domi quaerebat Mercurium)."

$\mathrm{I}$ am indebted to $\mathrm{Mr}$ J. G. van der Horst for this reference.

${ }^{2}$ Quoted by Groethuysen, op. cit. p. I 50.

3 Ibid. p. 199. 
Have a fixed hour for rising and going to bed; and, as far as you may, fix it so that you may be early to bed and up betimes. Nothing is more opposed to a regular and Christian life than late rising.

Above all, one had to eschew "laziness", and never forget that "all your devotions should be subordinated to the necessary duties of your estate, of your employment". I

Even Franklin's plan for ordering his life was the same as that recommended by French Catholics as a religious exercise. Father Réguis said:

One of the greatest advantages which one enjoys in religious houses and in all those where one lives in community, is following a definite rule which accounts for all the hours of the day, prescribing, so to say, the task for every minute.... Now, my dear parishioner, why should you not make yourself a rule which sets down in detail what you ought to do from morning till evening? 2

The argument based on Franklin's well-known rational aid to the progress of virtue, and the source from which it is said to be derived, is not much happier. Bunyan's picture of the sinner in front of God compared to a debtor facing his creditor, is quoted, and it is argued from this picture that the Puritan's relations with his God were business relations; that salvation was for him more or less a matter of a profit and loss account. 3 Here no allowance. seems to have been made for a teacher suiting his exposition to his readers or his congregation. If no account is taken of this, strange lessons might be drawn from Bible teaching-for instance, from the Parable of the Mammon of Unrighteousness. By itself, then, Bunyan's exposition is hardly significant. From the doctrinal point of view it would be easier to derive such a conception from the Catholic doctrine of merits than from Protestant doctrines of salvation by grace alone!

Franklin's account book, in which he posted details of his successes and failures in his striving after virtue, is given as a classic example of the idea of God's book-keeping. 4 But it is

I Ibid.

3 Weber, loc. cit. p. 123 (Engl. trans. p. 124).
2 Ibid. p. 218.

4 Ibid. 
unlikely that Franklin thought he was drawing up his account with God. His exercise in book-keeping was for his own satisfaction, to aid him in his search for virtue; it was not God's balance. Nor was it sufficiently differentiated from the similar books advocated by Catholics by the fact that these were to be kept with an eye to the confessional, to aid the confessor in providing guidance. They were intended in themselves to be a direct aid to virtue-and so was the confessional, which was not an end in itself. This attempt to show that the Puritans reduced religion to business methods also breaks down. And it should be remembered that it was the Catholics, by their tendency to concentrate on the formal more than the actual or real, who made release from the sin of usury depend to some extent on methods of accountancy.

Weber has collected a number of Protestant writings which seem to favour capitalism; but he has also mentioned that there was a strong current in Puritan teaching which stressed the dangers of riches, and the Christian's duty of not striving after them. ${ }^{\mathrm{I}}$ Is he right in saying that this was overshadowed by advice, pro-capitalistic in tendency, to work hard in an orderly way, especially when both elements were also prominent in Catholic teaching? He has not proved that the Puritans introduced a new economic ethic. The Protestants as well as the Catholics spoke with an ambiguous voice. But as a rule the Calvinistic contribution to the capitalist spirit was the same as that of the Jansenists or stricter school of Catholics, consisting of the encouragement of industry, thrift, order and honesty; while the Jesuits went further and favoured enterprise, freedom of speculation and the expansion of trade as a social benefit. It would not be difficult to claim that the religion which favoured the spirit of capitalism was Jesuitry, not Calvinism.

But there is an explanation of the relations between the Churches and the spirit of capitalism which is "more probable" than any other. A historical method of analysis may be introduced into the discussion.

I Weber, loc. cit. pp. 165 ff. (Engl. trans. pp. 15G-7, 259-60). 
Such a method has here been attempted. It has been shown how English Protestantism underwent a great deal of change between Lever and Richard Baxter, and between Baxter and the second Whole Duty of Man, "made easy for this present age". It has been shown how there was a progression from Luther to Gerhard, from Calvin to Saumaise, on the question of interest. It has been shown how there was a gradual relaxation of the economic casuistry of the Jesuits, and a rebuilding on a basis more in favour of capitalistic beliefs..$^{\mathrm{I}}$ All has gone to prove one point: that the Churches, one and all, have had to accommodate themselves to an extraneous development of a busy commercial spirit; that capitalism has created, or found already existent, its own spirit, and set the Churches the task of assimilating it.

The Church of the Middle Ages had easily known its duty towards the different classes of men, for there were only two important classes-the rich and great and the poor and miserable. As this simple class division became obsolete the Church was faced with new problems. They were beginning to become urgent when Aquinas wrote his famous half-hearted justification of the merchant's activities. St Antonino met them more insistent in fourteenth-century Florence. In the sixteenth century they had to be faced for the first time almost throughout Europe. The same problems affected all the Churches, and none had any previous experience to call to its aid.

The God of the Christians, in creating the world and in preparing the coming of his Church, does not appear to have foreseen that one day the bourgeois will claim his place and wish to play an important part there.

Yet, in modern times, how could the Church continue to neglect this citizen? It cannot abandon this upright man who knows himself to be somebody to the profane world. As formerly it had known how to give a religious character to those who, rich or beggars,

I My indebtedness to Father Duhr's article on "Die Deutschen Jesuiten im 5 Prozent-Streit des 16ten Jahrhunderts" is easily apparent. I should here like gratefully to acknowledge it. 
filled the world's stage, it must now interpret in its own way the social phenomenon which the bourgeoisie represents in modern times. It must be able to tell the bourgeois why God has created him, and assign him his functions here below. But how will it set about securing this bourgeois of quite profane origin? How will it join the mind and the manner of life of the bourgeoisie to religious traditions, in order to give it its consecration. In this order which binds Heaven and earth, whose beginnings go back to God, what might be the spiritual significance of the bourgeois? I

It was a problem which all the Churches had to face. A new hard-working, hard-headed type had sprung into prime importance. It was a type predisposed to regard itself as selfsufficient. It basked in the knowledge that it had done no man harm; that it fully deserved the honest portion which it had secured by its trade and industry. Even as sinners the new type sinned less palpably, less full-bloodedly than the other types, and, as we have seen from the reports of some of their confessors in Upper Germany, these "bourgeois" were unwilling to accept a burden of sin thrust upon them by a Church which was unsympathetic because ignorant of their ways, on account of actions in which they could see no wrong. ${ }^{2}$

I Groethuysen, op. cit. p. I68. Groethuysen shows in this remarkable work how the Jesuits managed to secure the reception of the new bourgeoisie into the Church in France - so far as they were assimilated, for the Church found it difficult to stretch as far as would accommodate them, and thus hastened the movement towards secularisation which Weber believes was the ultimate outcome of the Protestant economic ethic. Were space still available, I would like to quote extensively from this penetrating, witty and suggestive study. It does not touch on the topic of Protestant affinities for capitalism, but, accepting facts as they are found, and describing how the bourgeois came into his own in France amidst the struggles of Jesuit and Jansenist, it shows conclusively that the whole matter is not an affair of a church creating a new type, or even favouring one, but of a Church having to create for itself a new ideology in order to embrace one which has grown up independently.

2 Cf. Groethuysen, op. cit. p. 176: "Honnête homme, il sera un dilettante du péché, et l'Église se trouvera parfois bien embarrassée devant cet homme, qui tout pécheur qu'il soit, semble se dérober à ses anathèmes, 
It was left for the Churches to find a place for this newly important class. What we are told to believe is the Reformed Churches' formation of a capitalistic spirit is in reality only their attempt to find a place for the commercial classes, newly important and freshly aware of their importance. But the Catholics also attempted to fit the middle-classes into the ecclesiastical scheme; in some way to sanctify and find an otherworldly significance in their solidity, diligence and honest respectability-characteristics which were really virtues despite their worldly origin - and to justify the aims and methods of their trade.

mettant toujours en avant son honnêteté.... Il n'y a donc que le bourgeois qui pèche mal et qui, par son attitude et ses manières d'honnête homme, semble diminuer l'idée du péché". 


\section{Chapter VII}

\section{THE INFLUENCE OF THE DISCOVERIES}

Two observations which apparently led in the beginning to the elaboration of the theory of the Puritan affiliation of capitalism were first, the rise to economic importance of the more or less Calvinist countries of the north of Europe, such as England, Scotland and Holland, in the place of Catholic Italy and Spain and Upper Germany; second, the less noticeable commercial capacity and zeal of the Catholic minorities in Protestant countries as compared with the business skill and industry of the Huguenots in France or the Puritan minorities in England. $\mathbf{~}$ Due weight must certainly be given to these two considerations. The question remains: will they bear the construction which has been placed upon them?

The first will much more readily admit of a geographical explanation. It must not be forgotten that geographical conditions are never fixed-that some of geography's chief aspects even more than those of economics can only satisfactorily be studied in the light of history.

The new course of world trade which sprang up in consequence of the discovery of America and more especially of the Cape passage to the East was a much more potent cause of

I Weber, loc. cit. pp. 17 ff. (Engl. trans. pp. 35 ff.).

2 Cf. Troeltsch, The Social Teaching of the Christian Churches (Engl. trans. pp. 573-4): "If, speaking generally, the Protestant countries are the most progressive at the present time, we must not forget, on the other hand, that during the period when the Protestant churches were being formed the mother-lands of modern civilisation-Italy, France and Spain -were Catholic, and that their exhaustion has no connection with their Catholicism - that, thus, on the other hand, the Protestant countries too, and especially the Lutheran, cannot in any case ascribe their present position primarily to their religious bases, however important these may be in particular". 
these national inequalities than religious differences. Italy lost its importance as a centre for the distribution of eastern products through Europe, and as a natural result of this the Swabian cities such as Augsburg and Nuremberg, which owed their prosperity to their position on the main trade route between Italy and Central and Western Europe, also underwent a decline. I Even if Antwerp, London and Amsterdam were not more easy of access to the shipping which plied to the Indies than the Iberian or Mediterranean ports, they were certainly better centres for supplying the markets of Europe. This, together with the trade-killing policy of the Spanish crown which completely barred Spain and Portugal from any effective competition, was sufficient to cause the comparative retrogression of the great Catholic lands. ${ }^{2}$

The countries in the north of Europe had indeed been forging ahead before the time of the Reformation. Bruges and Antwerp had already begun the swift progress by which Italy was to be ousted from her position as commercial leader of Europe. That their rise was not due to the comparative lack of initiative of the Catholics is shown by the fact that Catholics contributed materially to the rise of the Low Countries. Large numbers of Italians, Portuguese and South Germans removed their businesses thither when they saw the trend which the world's trade was taking. Practically every Augsburg house of standing established itself in Antwerp in the sixteenth century, while the merchants from the south of Europe settled there in even

I See Wiebe, Zur Geschichte der Preisrevolution des I6ten und I7ten Jahrhunderts, pp. $205 \mathrm{ff}$., $282 \mathrm{ff}$. In these places Wiebe discusses the consequences of the discovery of the Cape route in altering the relative prosperity of the different parts of Europe, in order to explain the distribution of the newly found American silver amongst the different countries. In this admirable treatment of the problem he seems to me to provide entirely adequate explanations of the phenomena which Weber and his school wish to relate to differences in religious persuasion.

2 Professor Sée makes this point very neatly in his essay "Dans quelle mesure puritains et juifs ont-ils contribué aux progrès du capitalisme?" in his Science et Philosophie de l'Histoire, p. 320. 
greater numbers. ${ }^{\text {I }}$ It is known that Italians invested heavily in Holland as the commercial position of Venice declined, ${ }^{2}$ and Amsterdam was more of a cosmopolitan than a truly Dutch town. 3 When one calculates the economic effects of the different creeds on this geographical basis, it may well be that good Catholic capital and capitalists have been included in the balance on the Calvinist side. There were very practical reasons for the growth of capitalism in the north-western countries which happened to be more or less Calvinist. If we do not accept this explanation we must believe as an alternative that the Italians, who had been the chief exponents of the commercial arts up to the end of the fifteenth century, suddenly lost their interest in the subtleties of trade and finance. This sounds so fantastic that it could hardly seriously be advanced. 4

The second origin of the theories connecting Calvinism and capitalism lay in observations which seemed to show that Catholics in any country, whether they are in a majority or a minority, are less inclined towards industrial and commercial pursuits than the adherents of the Protestant sects. 5 But is this, or has it been, universally true?

The Fuggers, and most of the great financiers of the Renaissance period, were Catholics. In present-day Holland there are no signs of any slackening of commercial activity as a result

I On the merchants from the south of Europe in Antwerp, see the remarkable study by J. A. Goris, op. cit.

2 L. Brentano, Anfaenge des modernen Kapitalismus, p. 133.

3 E. Baasch, Hollaendische Wirtschaftsgeschichte, p. I3: "Also the continual presence of many foreigners, who pursued their trade here and to a greater or lesser extent mixed with the indigenous population, strengthened the cosmopolitan character of the town. At the end of the I6th century large numbers of Lombards settled in Amsterdam in place of Antwerp; a whole collection of Italian merchants lived here; very many merchants' names bear evidence of their Italian origin...".

4 It might be borne in mind that right through the seventeenth century two things which always greatly impressed the English economic pamphleteer were (a) the prosperity of Leghorn, due to its liberal trade policy, and $(b)$ the wealth and influence of the Genoese bankers.

5 Weber, loc. cit. pp. 2 I ff. (Engl. trans. pp. 37 ff.). 
of the widespread revival of Catholicism. Yet the revival of Catholicism in the Netherlands in recent years has been so marked that it appears to be only in Zealand that the country remains predominantly Calvinist-and Zealand is the least progressive of the provinces, a province of fishermen and farmers. Elsewhere Catholicism seems to be returning to prominencealong with industrial progress. The gilt-topped spires of Eindhoven, the most rapidly growing and perhaps the most prosperous town in Holland, seem to give the lie to any belief that Catholicism spells stagnation, while Catholic families like the Jurgens take a prominent place in the Dutch commercial world. Nor can Holland's commercial greatness in the sterner age of the seventeenth century be ascribed to a rigid Calvinism. Some of the chief exponents of commercial methods in Holland were Catholics-the Catholic Johan van der Veken (d. 1616) was one of the most active and influential merchants in Rotterdam. I This is not to be wondered at when it is considered that the revolt against Spain was in the first place a revolt for freedom against the Spanish system of government, in which Calvinist against Catholic played but a small part, Calvinism long continuing to have comparatively few adherents, who were, like the followers of most schismatic movements, confined in the main to the lower classes. ${ }^{2}$ The truce which marked the end of the first half of the eighty years' struggle against Spain still found the Catholics in a two-thirds majority in the Netherlands, and, according to Oldenbarnevelt, "la plus saine et la plus riche partie". 3 -Dutch Calvinism itself was never a

I Baasch, op. cit. p. 9 .

2 P. J. Blok, History of the People of the Netherlands (Engl. trans. III, p. 22): "Not that Calvinism or the doctrine of the Baptists, or Mennonites, found many adherents among the well-to-do citizens. On the contrary, although heresy was spreading to all classes of the population, it was in the main-just as in the time of the Baptists-the lowest classes who were chiefly affected by its spirit. In proportion to the whole population, the number of Calvinists was small...". Cf. P. Geyl, The Revolt of the Netherlands, pp. 16, 83, 105, 127, 131, 161, 178, 275 et al.

3 Blok, op. cit. III, p. 415 . 
religion of extremes, and the most prosperous merchants formed a minority who had no religion at all, $\mathrm{I}$ even when they had for convenience nominally embraced Calvinism! The economic and social life of the Dutch burghers seems, indeed, to have been completely uninfluenced by the teachings of the Calvinist Church. There seems to have been a marked lack of honesty both in private dealings and in the conduct of public business ${ }^{3}$ fraudulent bankruptcies were the order of the day, and "to lie like a broker" became a proverbial expression.4 Little account seems to have been taken of those Calvinist virtues, frugality and thrift, which are said to have contributed so largely to the rise of a spirit of capitalism. The spread of luxury was very marked in seventeenth-century Holland, showing itself in high living, in the erection of costly and magnificent dwellings, in patronage of the arts, in the aping of foreign manners, in personal adornment, perhaps finding its highest expression in the great tulip mania. 5 The picture which we form is that of a people unwilling to give up its pleasures at the behest of the preachers. The Kermis, or Church fair, was one of the favourite institutions of the Middle Ages. It developed in the same way as the English fairs, and Ben Jonson's Bartholomew Fair would have provided also a just description of a Dutch Kermis, a place for drinking and riotous jollity, and a happy hunting-ground for mountebanks and soothsayers. Naturally it was anathema to the predikants, but the people re-

r Ch. de Lannoy et $\mathrm{H}$. Vander Linden, L'Expansion Coloniale de la Néerlande et du Danemark, p. 25: "Ardent Calvinists... were relatively few, save in Zealand.... The upper middle classes of these towns, of Amsterdam for example, were even largely composed of 'libertinists' or religious indifferents...".

2 Baasch, op. cit. p. 8: “... The old spirit of confessional indifference lived on amongst the capitalistic classes of the North, even after they had formally adhered to Calvinism...".

3 Blok, op. cit. IV, p. 93.

4 D. J. Schotel, Het Maatschappelijk Leven onzer Vaderen in de Zeventiende Eeuw, 2nd ed. pp. $225 \mathrm{ff}$.

5 Blok, op. cit. III, p. 354; IV, pp. 9r ff.; Schotel, op. cit. pp. 229-30. 
fused to be weaned from it. ${ }^{I}$ Nor were the preachers any more successful in their campaign against the theatre, a theatre which loved to poke fun at the clergy and exhibit them in no amiable light. ${ }^{2}$ The Dutch merchants' well-known love of gain expressed itself in ways most distasteful to the Church-in trade with the enemy, ${ }^{3}$ and in attention to business cares on the Sabbath 4 - but again the Church was unable to secure any amendment. It might indeed almost be said that the expansion of Dutch trade and the development of the commercial spirit were carried on in spite of the Calvinist Church rather than because of it, that Dutch Calvinism was opposed to the working of the capitalist spirit, 5 and that Calvinist Holland was quite distinct from commercial Holland.

It is true that a great economic expansion coincided with a widespread adoption of Calvinism in the Southern Netherlands in the sixteenth century. It is true, moreover, that Calvinism spread more widely amongst the merchants and entrepreneurs of the ports and industrial districts than amongst the farmers of Luxemburg or the small independent workmen of the district of Liége. But it was only to be expected that well-to-do merchants who were in constant intercourse with other merchants of all creeds and nationalities should have been readier to discuss and to accept new opinions than the more stolid and more

I Schotel, op. cit. pp. 273-4.

3 Blok, op. cit. 1II, p. 186.

5 Cf. Blok, op. cit. IV, pp. 3-4: "The indefatigable Usselincx, himself a stern Calvinist and enemy of all 'heretics and erring spirits',... desired a limitation of the power of the directors over the shareholders [of the West India Company]... the promotion of civilisation and Christianity among the natives, and especially a regular supervision by the state of the doings of the merchants 'who have gain for their north star and greed for a compass, and who would believe the ship was keeping to its right course, if it were almost wrecked by profit"”. Ibid. Iv, pp. 153-4: "The.'profit" of the merchant became more and more the principle guiding the policy of the States.... But on the other side stood. .. . the old Orange war party. It could still count upon the preachers, whose hatred against Spain and Rome was coupled with a strong aversion to commerce, which they abominated as incompatible with true religion". 
isolated peasantry-and they were not readier to embrace Calvinism than the industrial wage-earners. As the merchants were strongly opposed to the policy of interference of His Most Catholic Majesty of Spain and to the introduction of the Inquisition they had a natural tendency to favour the religion which joined them in opposing it; and as it was impossible, for commercial reasons, to employ the Inquisition in the business centres with the same ruthless success in extirpating heresy as elsewhere, there was every reason why Calvinism should have been strong there: ${ }^{I}$ Another factor of great importance in securing the "capitalist" classes for Calvinism bore no relation to any capitalistic t_ndency within the Reformed religion. This was the attitude of the Marraños, the nominally converted, yet persecuted Spanish and Portuguese Jews, who played a great part in the economic life of Antwerp. The Marraños had at first rallied to Luther.They were attracted to this new preacher who did not seem to hold the Jews in despite, but, on the contrary, reminded the world that "Jesus was a Jew by birth", and attacked their persecution; who protested that Christianity could not expect to make converts in the face of the Christians' bestial treatment of the Jews. Therefore the Marraños were at first strong in support of their new champion. ${ }^{2}$ But, like many others who had relied upon the inconsistent Luther, they were doomed to disappointment in their hero. Then, having been made Catholics by force and Lutherans through hopes destined to be unfulfilled, thoroughly disgusted with both Catholicism and Lutheranism and not strong enough to stand by themselves as Jews, they lent their support to the Calvinists when the religion of Geneva began to spread in the Low Countries. Calvinism at any rate stood neither for the Inquisition nor for the anti-

I Cf. H. Pirenne, Histoire de Belgique, III, pp. 434-6; L. van der Essen, "Les progrès du luthéranisme et du calvinisme dans le monde commercial d'Anvers", in Vierteljahrschrift fuer Sozial- und Wirtschaftsgeschichte (1914), pp. I 22 ff.; P. Geyl, op. cit. pp. 81-3, 92.

${ }^{2}$ Kalkoff, Die Anfaenge der Gegenreformation in den Niederlanden, I, pp. 4 I ff. 
semitism of the later Luther. For these reasons, and not on account of any affinity between Calvinism and capitalism, one very influential commercial community was gained for the new religion.

It is also argued that the Nonconformists and Quakers in England showed much more commercial activity than the members of the Established Church. This is to a large extent true; but it does not mean that Nonconformist beliefs had formed the commercial spirit of the congregations. The obvious explanation lies in the overwhelming influence of the landed interest in the English Church. It was land-holders who possessed Church patronage, and it was only natural that those who were excluded from power in the English Church should tend towards dissent, as it was only in the dissenting Churches that they could feel they were esteemed at their true worth. For that reason the conventicles were the resort of the proletariat as well as of the commercial middle-classes. Levy, who has elaborated this point, ${ }^{1}$ has not realised the force of his quotation from Wood's Survey of Trade of I719, to the effect that:

Those who differ from the Established Church are generally of the lowest rank-mechanics, artificers and manufacturers.

The fact that these classes were also given to dissent suggests that the reason for nonconformity amongst the merchants and the labourers was the same-the desire to belong to a Church of which they could feel they formed an important part. ${ }^{2}$

I H. Levy, Economic Liberalism (Engl. trans. pp. 62 ff.).

${ }_{2}^{2}$ L. Brentano, Anfaenge des modernen Kapitalismus, p. 146 n., draws attention to the illegitimacy of Levy's employment of the passage from Wood. Cf. the remarks of Troeltsch, The Social Teaching of the Christian Churches, p. 50, on the social standing of the early Christians: "A religion which sets its adherents in absolute opposition to the State religion, and to the social and civic customs with which it is concerned, can only now and again, quite exceptionally, win its adherents among those circles which, by their wealth and education, are most closely connected with those institutions. It was for the same reason that the Austrian Los-von-Rom movement, for example, was most successful among the lower classes; they were less closely bound up with the dominant religious system". 
That external material conditions play the deciding part in forming the capitalist mind is also indicated by the complete "a-capitalism" of the South African Calvinist farmers. From the beginning of European settlement there was an almost complete lack of markets to supply an incentive to capitalist enterprise. Until the diamond and gold discoveries the opening up of the interior was more of a dispersal to carry on subsistence farming than anything else. Climatic and soil variations and insect pests militated against systematic and rational culture. These difficulties are still very great, and the Union has hardly yet even a market sufficiently metropolitan in character to call forth great endeavours to overcome them-with the result that the farmers of South Africa have never lost the non-capitalistic outlook which early conditions of settlement made inevitable. So striking is this that one sometimes hears comment on the successful resistance of the old Cape Colony to the proposal to make it a penal settlement, to the effect that it is a pity the convicts did not come, for they would at any rate have proved more enterprising than Calvinists! It does not, then, appear to be universally true that capitalistic enterprise has been chiefly associated with Calvinism and the Puritan sects; and where the association has been apparent, there have been non-doctrinal causes strongly at work.

But not only may the changes in the relative prosperity of the European peoples which have been ascribed to religious factors be more convincingly related to the altered course of trade which was brought about by the great discoveries- the development of the capitalist spirit may also be shown to have a strong connexion with the discoveries.

"The discovery of America and that of a passage to the East Indies by the Cape of Good Hope", said Adam Smith, "are the two greatest and most important events recorded in the history of mankind." They inaugurated a notable phase of European commercial expansion. But their importance is not confined to the strictly material sphere. For the consequent expansion of commerce meant a necessary expansion of ideas. An alteration 
in the typical attitude towards making one's living had to follow an alteration in the typical ways by which important sections of the population actually earned their living. When Florence, Genoa, Venice and the other Italian cities were busily engaged in expanding trade in the Mediterranean they were centres of a capitalistic and individualistic movement of which the Renaissance formed a part. It seems likely that the expansion of trade in the Atlantic and Indian Oceans was a prime cause of the growth of economic individualism in Western Europe in the sixteenth and seventeenth centuries. ${ }^{1}$ The emergence of economic individualism, making the spirit of capitalism a respectable basis for the organisation of economic effort, rests upon the severely practical ground of the existence of forms of social organisation favourable to it. It may be argued that modern economic society has developed as the result of the operations of a spirit of capitalism, formed independently through religion or some other cause. But a developed "spirit of capitalism" is a function of an organisation of the economic system in which trade and industry are carried on by entrepreneurs in search of profit, and is therefore largely dependent on there being opportunities for its exercise. That is to say, the spirit of capitalism is not the creator but the creation of the class of business men. The discoveries provided an immense increase of economic opportunity. They greatly stimulated that development of commerce already in progress whereby markets and sources of supply were sought further afield, throwing out of date all medieval attempts at regulation; they increased opportunities for making money and the scale of operations. The medieval attitude to enterprise-that one should not seek for gain, but only to gain a living-was only possible so long as opportunities were so meagre as to prevent the average business man notably offending against the rule. The discoveries, however, meant an increase of economic opportunity, a rise in the

x Cf.Earl J. Hamilton, "American Treasure and the Rise of Capitalism" in Economica, November 1929; J. M. Keynes, $A$ Treatise on Money, II, pp. I 52 ff. 
importance of liquid capital applied in trade or industry for the sake of increase, as against inherited feudal wealth, the concentration of this capital in the hands of an active entrepreneur class, and, owing to large stocks of silver being imported into Europe from the Americas and a consequent sudden marked rise in European prices taking place, the rule of custom was also rudely shattered in the economic life even of those who did not directly concern themselves with the exploitation of new markets on the basis of fresh currency supplies. Business methods changed with the enlargement of the economic horizon, and so the modern spirit of capitalism arose, following upon this practical fait accompli. Society discarded its old philosophy of business as it came insensibly to accept the code of the newly important class of men of affairs. I It might be well to consider what special influences on business enterprise and organisation were exerted by the great discoveries.

The Spaniards had established their dominion in America and the West Indies primarily to secure treasure. They were successful beyond all reasonable expectation, if not beyond their wildest hopes. It is impossible to calculate with any exactness what the effects of the influx of silver from Spanish America on Europe's monetary stocks have been. The stocks of the precious metals in Europe in 1493 have been estimated as:

Gold: $\quad 550,000 \mathrm{~kg}$. of the value of $£ 53,212,500$

Silver: $7,000,000 \mathrm{~kg}$. $\quad " \quad £ 63,000,000$

$£$ I16,212,500

In 1544 they are reckoned to have been

Gold: $\quad 815,000 \mathrm{~kg}$. of the value of $£ 82,518,750$

Silver: $9,190,000 \mathrm{~kg}$. $, \quad, \quad 82,710,000$

$£ 165,228,750$

I Cf. H. M. Robertson, "Sir Bevis Bulmer, a Large-Scale Speculator of Elizabethan and Jacobean Times", in Journal of Economic and Business History, iv, No. I, November I931, pp. 99 ff. 
In 1600 they have been reckoned to have been

Gold: $\quad 1,192,000 \mathrm{~kg}$. of the value of $£_{13} 1,590,000$ Silver: $21,400,000 \mathrm{~kg}$.

$" \quad \Rightarrow \frac{E_{1192,600,000}}{£_{0324,190,000^{r}}}$

These calculations include all stocks of the precious metals, of which the greater part would be in the form of plate. Chevalier has calculated that there were $87,000 \mathrm{~kg}$. of gold and $3,150,000 \mathrm{~kg}$. of silver employed as monetary stocks at the beginning of the sixteenth century. ${ }^{2}$ At the same conversion rates these would be worth something over $£ 40,000,000$. Jacob calculated that they stood at an even lower figure-about $£ 33,000,000.3$ The probabilities are, therefore, that the rate of increase of the circulating medium was even greater than that of the total stocks of gold and silver, even though these trebled within 100 years.

The consequences of such an increase are well known. When the proportion of money to goods is increased, prices rise. But not all prices rise equally. Much depends on the channels by which the new supplies flow in. They are not added mysteriously to the general stock of money; they are additions to the purchasing power of individuals. Some of the increase in the money supply came from a larger production in the European mines, some came from the North African trade, the bulk of it from the Spanish possessions. The great increase came after the discovery of the Potosi mine in 1545. The treasure was sent to Spain, and it was theintention of the government that it should stay there. But it could not. Spain was not able to feed herself, let alone provide all that was necessary for

${ }^{1}$ Tables given in Wiebe, op. cit. p. 28r. The values have been roughly converted from marks at a par rate of 20 marks to $£$ I.

${ }^{2}$ Quoted in A. Liautey, La Hausse des Prix et la Lutte contre la Cherté en France au $\mathrm{xvI}^{\mathrm{e}}$ Siècle, p. 64 .

3 L. L. Price, Money and its Relation to Prices, p. 150. 
a growing colonial empire, which busied itself only with fighting and mining. The Spaniard, as Bodin pointed out, could not live without his French supplies. So the Spanish gold and silver found its way into France by means of foreign trade. It found its way even more readily into the Spanish Netherlands, and into Germany and Italy, for the Spanish kings had been borrowers from the capitalists of Upper Germany and Genoa and these were granted special licence to export the precious metals from Spain.

The new supplies were, therefore, distributed through Europe by the foreign trader. It was he who reaped the first benefit of the increased priees in Spain, and by seeking the dearest market, forced all to rise. For though there was an insufficient international trade in those days to bring about anything approaching a general purchasing power parity, a European level was roughly attained for the chief articles of international commerce. ${ }^{\mathrm{I}}$

As those who believe that Protestantism created the "spirit of capitalism" rely largely on English sources, it might be well to consider how England specially was affected by the price movements of the sixteenth century. She was late in securing any share in the American supplies. The delay was due, first to her insignificant foreign trade as compared with that of the chief countries of Western Europe; secondly, when this factor was beginning to grow less important, to her bad monetary policy. Before 1543 the silver coin of England had contained II oz. $2 \mathrm{dwt}$. of silver to the pound: in 1550 , coin was issued containing $3 \mathrm{oz}$. of silver to $9 \mathrm{oz}$. of alloy. The weight of the coins was also subject to alteration. English prices rose rapidly as a result of debasement-but the rise bore no relation to the general upward movement of prices. An external depreciation of the English currency was set up-that is to say, the general purchasing power of the debased shilling was greater at home than

I The author of the Discourse of the Common Weal (I549) stressed this point. On the manner in which the new supplies were distributed through Europe, see Wiebe, op. cit. pp. $282 \mathrm{ff}$. 
abroad.I Thus England was cut off from the general course of price movements. Her good currency-except such as might still be absolutely necessary for the upkeep of the circulationwas hoarded or went abroad; she received no influx of American silver; she experienced an independent rise in prices-but the foreign exchanges more than discounted this rise.

The effects of such a situation were far-reaching and disturbing. The whole economic relations of the country were upset, relations in which custom had played a large part. Great controversies arose about the dearness which prevailed in the midst of plenty. The farmers were blamed for it, and transferred the blame to their landlords for having increased their rents, and to clothiers and ironmongers who made them pay more for their materials. The landlords said the fault was not with them-for they were unable to increase their rents sufficiently to compensate them for the increased cost of living. And so the mutual attributions of avarice went on-though a few were wise enough to see that the cause of all the disturbance lay in the monetary situation. ${ }^{2}$ All contracts made at the old price-level acquired an entirely different real value. This led to competition amongst all classes in their attempts to maintain their old standards of living. Society was forced into the adoption of a more individualistic attitude by the mere rise of prices; the rule of custom was overthrown by the alteration of

I That the debased coins were over-valued at home considering their metallic content is shown by Oman, "The Tudors and the Currency", in Transactions of the Royal Hist. Soc. N.S. IX, p. 181. The general reason for an external depreciation is a distrust which over-discounts an internal depreciation; external depreciation can only subsist over a long period if resort is continuously made to debasement (or inflation). External debts are another factor in prolonging external depreciation, and the English crown was a constant debtor of the Continental capitalists on whom it still depended.

${ }_{2}^{2}$ The Discourse of the Common Weal is largely an elaboration of this theme, in which the Doctor upholds the monetary explanation. Gerard Malynes, Lex Mercatoria (I636 ed., pp. 47-8), gave a description and explanation of the controversies essentially identical with the discussion in the Discourse, and probably borrowed from it. 
customary equivalents; each man had to fend for himself and try to maintain his position against the rising price-level. When the doctor in the Common $W$ eal complained of the landlords turning arable into pasture, the knight replied "Yf they finde more proffite therby then otherwise, why should they not?"I When one considers the landlords' difficulties, the feeling which prompted the knight's question seems reasonable. In $155^{\circ}$ Lever complained:

For euen you husbandmen whyche crye out vpon the couetousness of gentlemen and officers, it is euen couetousnes in you, yat causeth, and ingendreth couetousnes in them. For, to get your neyghbours ferme, ye wyll offer and disire them to take bribes, fynes, and rentes more then they loke for, or then you your selues be wel able to pay. ${ }^{2}$

Yet he was not, as he imagined, observing a new manifestation of human greed, but a revolution in prices which had greatly affected all land values, and commercialised the land.

These were effects simply of the rise in prices. The external depreciation of the English currency set a bounty on exports. The chief export of England was her cloth; so the clothindustry, the industry which had evolved furthest in the way of speculative production, of specialisation of function on the basis of free enterprise, was given an artificial stimulus. This was largely responsible for the movement for sheep-farming, which was such a burning topic in its day-a movement which certainly seems to have marked the death of the old customary or communal life of the manor. The enclosure movement was also facilitated by the entry of commercial capital into landholding. 3 This again was to a large extent the result of three causes- of the rise in importance of the merchant classes, which was materially helped by rising prices; of the decline of the land-holding classes, in which the rise of prices played a part;

I Discourse, p. 50.

2 Thomas Lever, Sermons (1550), ed. Arber, p. 37.

3 Wiebe, op. cit. pp. 232-3. 
and of the formation of a market in land, with which the rise in prices was also intimately connected.

In all cases rising prices tend to benefit the commercial classes at the expense of labour, owing to the time-lag which occurs before wages are adjusted to a new price level. But the new land economy caused a diminution in the demand for labour. Population had already been increasing at a rapid rate, more rapidly than the demand for labour. The result was that wages showed an even greater inclination to lag behind, while the rise in price of the articles of general consumption was more than proportionately increased.I Therefore profits increased, but labour discontent and the growth of the "class war" was violently stimulated, especially in the woollen industry, where the rise of "clothierism" had greatly enhanced the speculative nature of production, and where so much depended on the freedom of the Continental market from war disturbances and on the course of the foreign exchanges. Exchange rates were liable to fluctuation not merely on account of bullion movements, but because of the incalculable financial measures of the governments of Europe-all of them were large borrowers who were willing to try any experiment when the time for repayment came round, and practically none showed any aptitude for finance. The most cursory glance through the special legislation for the cloth industry and the records of the dealings of the Privy Council with the clothiers and the chief exporters of cloth, the Merchant Adventurers, is sufficient to establish much social unrest caused by the rapid development of this industry on a peculiarly speculative basis. ${ }^{2}$ There must have been many occasions of friction in the woollen industry, when,

I Wiebe, op. cit. p. 227; Hamilton, op. cit. pp. 349 ff., and Keynes, op. cit. II, pp. $158 \mathrm{ff}$., give calculations which attempt to measure the extent of the disparity of the rises in commodity prices and wage rates-and therefore of the extent of the "profit inflation". An international enquiry is also being organised.

2 Cf. W. R. Scott, Joint Stock Companies to 1720, in which early trade fluctuations are minutely traced. Cf. also E. Lipson, Economic History of England, passim, more especially III, pp. $294 \mathrm{ff}$. 
as Deloney put it, "the poore hate the rich, because they will not set them on worke; and the rich hate the poore, because they seeme burdenous; so both are offended for want of gaine". . These class conflicts inevitably brought about a lessened feeling of solidarity, a greater prominence for sectional interests, and new conceptions of the place of the individual in society.

English society was in any case destined to be disintegrated and moulded anew by a revolution of prices which would bring with it a dislocation of normal life, a forcible obtrusion of economic problems into the minds of all classes, placing in relief the individual struggle to retain some control over one's worldly condition; which would bring more speculation and more commercial activity; but these effects were very much enhanced by the manner in which the rise was first brought about -by the flight from the debased currency of $1543-5 \mathrm{I}$, by the export stimulus which was provided by an unfavourable movement of the exchanges.

The great recoinage of I560-I did not, fortunately for England's trade, have a deflationary effect. ${ }^{2}$ The path was now open for a steady flow of the American bullion into the country, a flow which, especially from the I570's, was accelerated by privateering expeditions. At the end of the fifteenth century the amount of silver coined annually in England was approximately I $100 \mathrm{~kg}$. Though this increased under Henry VIII the amount cannot be readily estimated, but under Elizabeth the

I T. Deloney, Jack of Newberrie (Works, ed. F. O. Mann, p. 43). Deloney was apparently describing the situation about 1525 , when trade was interrupted by Continental wars.

${ }^{2}$ It had of course a temporary effect of deflation, but this soon passed away. The deflation was even greater than was necessary; owing to a mistaken calculation the old coinage was "cried down" too far. Gresham has admitted that the result of the incomplete restoration of the coinage of $155 \mathrm{I}$ was to reduce the price of wool from $26 \mathrm{~s} .8 d$. to $16 \mathrm{~s}$. and of cloths from $£ 60$ a pack to $£ 40$ and $£ 36$ a pack; and to contract production in the cloth industry (Unwin, Studies in Economic History, pp. 152-3). The results of Elizabeth's recoinage would have been appalling, but for the presence of the American supplies, which ensured that the distress caused was purely temporary. 
annual coinage soon reached $12,000 \mathrm{~kg}$. ${ }^{\mathrm{I}}$ Trade expansion was not, then, checked by the return to a sound currency; some of the more purely financial speculations were curtailed, but industry and commerce still progressed on a rising price-level and enterprise continued to reap a good reward. The bounty on export provided by the external depreciation disappeared, but foreign trade was in general facilitated by the return to a sound currency; the tide of prosperity continued to flow for the manufacturing and commercial classes. ${ }^{2}$

Adam Smith coupled with the discovery of America that of the sea-passage to the Indies. It was in an attempt to find the West Passage to India that Columbus sailed in I492, and it was the silver which accrued as the result of the discovery of America which enabled the European merchant to implement the opportunities provided for him by the discovery of the Cape passage. For the trade with the East was only carried on by means of the export of the precious metals; silver was the commodity which India demanded, not the manufactured or natural products of Europe. Thus the East Indian trade only throve by means of the American silver, and an estimate of the exports of silver to the East will give a clue to the importance of the Eastern trade. According to an estimate of Soetbeer the drain to the East amounted to $£ 500,000$ annually in the second half of the sixteenth century and in the next half-century an

I Wiebe, op. cit. p. 3 I3.

2 On the effect of the bullion taken as prizes by the privateers cf. Keynes, op. cit. II, p. 156, n.: "The boom-period in England definitely began with the return of Drake's first important expedition (his third voyage) in I 573, and was confirmed by the enormous gains of his second expedition which returned home in 1580 , whilst his third expedition of 1586 was not entirely negligible. The value of the gold and silver brought back in the Golden Hind, which was carefully concealed at the time, has been variously

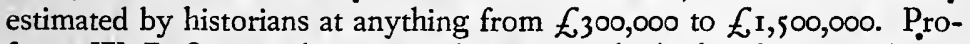
fessor W. R. Scott inclines strongly towards the higher figures and produces evidence to show that it must have exceeded $f 600,000$ at the least. The effect of these great influxes of money in establishing the "eleven years of great prosperity', from $1575-1587$, must have been predominant". 
average of $£, \mathrm{I}, 000,000$ was reached. Dutch and Portuguese merchants also exported large sums out of Japan-Wiebe has suggested $£_{30,000,000}$ of silver between 1570 and 1670 and $£$ I $5,000,000$ of gold in the second half of the sixteenth century - most of which was employed in trade with India and China; and there still remained the trade through the Levant. ${ }^{\mathrm{I}}$ All this represented an entirely new trade, one which opened up

I Wiebe, op. cit. pp. 277-80. If one compares Wiebe's estimate for the total stocks in Europe in $\mathrm{I} 660$ with an estimate of what these stocks would have been without making allowance for the drain to the East one can discover (it is not given directly) what the export amounted to in the view of this scholar. The stock of the precious metals in 1493 is valued at $2,324,250,000$ marks (p. 281). The production, 1493-1660, is valued at 9,874,138,000 marks (pp. 272-3). This would mean a stock of $12,198,388,000$ marks in 1660 , as against an estimate of $9,752,400,000$ marks (p. 282). This means a drain eastwards of approximately $2,446,000,000$ marks, or

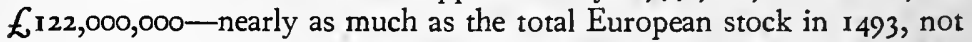
merely of coin, but of the precious metals in general. The calculation may be made another way. The gold stock in 1493 was $550,000 \mathrm{~kg}$. (p.281). The production, 1493-1640, was 1,028,000 kg. (p. 276). The annual average I64I-60 was $7870 \mathrm{~kg}$. which means a total of approximately $157,000 \mathrm{~kg}$. for that period (pp. 272-3). By 1660, then, the gold stock would have been $1,735,000 \mathrm{~kg}$., but it is estimated as $1,580,000 \mathrm{~kg}$., leaving $155,000 \mathrm{~kg}$. unexplained. The silver stock in 1493 was $7,000,000 \mathrm{~kg}$. (p. 28I) and by $1640,33,600,000 \mathrm{~kg}$. was added (p. 276). The yearly average for I $64 \mathrm{I}-60$ is given as $337,600 \mathrm{~kg}$. (pp. 272-3) which would make 6,752,000 kg. for the period. Thus by 1660 the stocks would have amounted to 47,352,000 kg., whereas Wiebe estimates them at 31,270,000 kg. (p. 282), leaving $16,082,000 \mathrm{~kg}$. to be accounted for by export to the east. That is to say about $\mathrm{x} 3$ per cent. of the new production of gold and 40 per cent. of the new production of silver was employed in trade to the East-nearly 25 per cent. of the combined new production; and there was exported nearly a third as much gold and over twice as much silver as the total stocks in I 493. These figures should be reduced to allow for the loss due to wear and tear; but, on the other hand, they should be increased by the amount exported through the Levant, which Wiebe has not taken into account because of the impossibility of estimating it. It will readily be seen what an increase in the total European trade these figures indicate; and they only represent a guide to the capital outlay of the Eastern merchants-when their enormous rates of profit are taken into account the significance of this new trade is still more apparent. 
avenues of profitable employment, access to which had hitherto been impossible. But such a trade demanded enterprise; merchants who engaged in it were not likely to believe in oldfashioned notions about their function, they knew that it was to buy as cheaply and sell as dear as possible.

The spirit of trade expansion which was provoked by the Indian and American discoveries led to further explorations. The Spaniards and Portuguese were content to exploit, without developing, the large areas which they had appropriated. But the French, the English and the Dutch had their enthusiasm roused. Hakluyt and Purchase admirably represent the spirit of their age. It was the attempt to make the North-East Passage to the Indies which led to Chancellor's discovery of Archangel and the opening of the Russian trade to Englishmen, and through Russia, of trade with Persia and the East. It was the attempt to make the North-West Passage which led to Frobisher's less immediately lucrative expeditions. These, however, were the forerunners of the English establishment in the Hudson's Bay Territory, where a rich profit was made from the. trade in furs, and of the Dutch expedition, also under Hudson, from which New York has sprung. The English managed to make an entry into old trade-routes, where they had previously been unable to compete. In the first part of the sixteenth century the French had managed to secure a large part of the Mediterranean trade. ${ }^{\mathrm{S}}$ But the wars of religion intervened: England took advantage of them to flood France with her merchandise, ${ }^{2}$ and came to an agreement with the Sultan of Turkey in 158r, by which a share of the Levant trade was assured. Both English and Dutch merchants tried to expand their trade in the Balticand here the Dutch were much the more successful. The African coast was much frequented by the ships of many nations-particularly the English, Dutch and Portuguese-and Hawkins began his profitable slave-trade.

I Bodin, Discours et Response au Sieur de Malestroict, folio 5 I (ed. of 1593, in one pagination with the Apologie de Réné Herpin); Wiebe, op. cit. pp. $296-7$.

2 Liautey, op. cit. p. 73. 
After a time both English and Dutch came to compete with the Spaniards and Portuguese in the territories which these claimed as their monopolies, and between them they managed to engross a great part of the benefit of the East and West Indian and South American trade.

Later, to the two types of colonial or inter-continental trade - that is exploitation of uncivilised peoples and trading with civilised peoples - there was added the third-in which settlers went out to engage in agriculture in the new lands. The English plantations were the great example of this; and entirely new enterprises were started, such as the growing of tobacco.

The capital required for all this foreign investment was provided by the profits of previous investments. When the Levant Company was founded in 1580 , "Elizabeth lent the governor and three assistants a sum of over $£ 40,000$, obviously a part of the great capture brought home by Drake in the previous year".. The East India Company was formed with capital largely acquired in the Levant trade - and up to the termination of the "First joint-stock" in I6I7 it secured returns of $£$ I,028,281 on an average capital of about $£ 200,000.2$ Enormous gains were made in the African and Russian trade. 3 At first a profit of 40 to 60 per cent. was considered poor in the African trade. 4 Between I608 and I6I5 the Russia Company paid aggregate dividends of 339 per cent., or an annual average of $42 \frac{3}{8}$ per cent.-making $£ 219,288$ profit on a capital of $£ 64,887.5$ The investment of capital in privateering rapidly mounted from the $£ 875$ of Frobisher's expedition of 1576 to the $£ 57,000$ of Drake's I 585 and the $£ 78,500$ of his 1587 expeditions. ${ }^{6}$ The returns brought in stimulated personal expenditure, which again enlarged the profits of overseas traders. "The growth of luxury, after the privateers began to capture Spanish treasure, increased the demand for the goods brought

I W. R. Scott, Joint Stock Companies to 1720, I, p. 70.

2 Ibid. I, p. 146.

4 Ibid. I, p. 43.

3 Ibid. I, p. 23.

${ }^{6}$ Ibid. I, pp. 77, 87.

5 Ibid. I, p. 145. 
from Persia; while the activity in English shipping added to the steady demand for ropes and sail-cloth"I_-much to the benefit of the Russia Company.

There was no doubt that expenditure was increasing as a result of trade and privateering.

Persons who had obtained large gains from the expedition of 1577-80 spent money freely and there were complaints of luxury and extravagance.... Sir John Hawkins, who, as Treasurer of the Navy, may have had opportunities of forming an opinion, estimated that since 1588, the wealth of England had trebled.... As early as 1579 Burghley described England as "surely abounding in riches", and the liberation of the captured treasure accentuated the general prosperity. ${ }^{2}$

This meant that not only was there greater activity and greater profit in the trades which provided for this expenditure, but also that its diversion into saving was made comparatively easier. This was recognised by those who were busily engaged in trying to start new enterprises. The author of a project for reorganising (and what would to-day be called rationalising) the fishing industry wrote that

In the obieccon' therefore of want of money to sett on foote this worke, it would seeme ridiculous to strangers that behold the wealth and glorie of this kingdome, with the sumptuous Buildinge, the costly inside of howses, the masse of plate to decke them, the dailie hospitalitie, and number of servants to honor their maisters, and their charitable Almes distributed out of their superfluities.... 3

In the later sixteenth and the seventeenth centuries there was undoubtedly in existence a fairly numerous class of specialists in the formation of new enterprises, functioning because of the greater opportunities of profit now opened out and the much greater opportunities of securing capital with which to start an enterprise now available. The business projector or promoter
I Ibid. 1, p. 69.
2 Ibid. I, pp. 83-4.

3 University Library, Cambridge, MS. Gg. v. 18, folio 209. (Second decade of the seventeenth century.) 
was a sixteenth-century creation, and one who brought into being a new philosophy of business and paved the way fo: modern large-scale capitalistic enterprise. It was no wonder, in such a promising material environment, that the growth of a business sense should have been a noticeable feature of the age of the discoveries in England. A general pre-occupation with business affairs had already been noted at the very beginning of the seventeenth century, and expressed in phrases strongly reminiscent of Adam Smith:

There is nothing in the world so ordinarie and naturall vnto men, as to contract, truck, merchandise and traffique one with an other, so that it is almost vnpossible for three persons to converse together two houres, but they wil fall into talke of one bargaine or another, chopping, changing, or some other kinde of contract. ${ }^{\mathrm{I}}$

This much more informed opinion created by an age favourable to enterprise served England in good stead in the troubled days of the sixteenth century. Capital supply was elastic and easily directed into new channels, which was more than useful when political disturbances made settled courses of trade unprofitable. ${ }^{2}$ The stimulation of foreign adventure and the surpluses of capital resulting from it reacted favourably on home developments. Schemes for Ulster plantations, fen drainage, mining operations and projects of all sorts were begun or canvassed in England in the later sixteenth and more particularly in the seventeenth century. A wave of speculation affected all classes. One of the episodes in Deloney's Pleasant History of the Gentle Craft concerned Simon Eyer, a humble London shoemaker, who by a sharp practice of which the

I Wheeler, Treatise of Commerce (1601), pp. 2-3.

${ }^{2}$ Scott, Joint Stock Companies to 1720, I, Pp. 65-6: "The continuance of the destructive war in the Low Countries tended to the disturbance of the wool industry, and the English capital, so displaced, had to find fresh outlets. Much of the prosperity of the years from 1575 to 1586 depended on the fact that Englishmen had the initiative and the courage to discover profitable openings for the resources so released". 
modern equivalent would be obtaining credit by false trade references, secured a shipwrecked cargo which he sold at a handsome profit, thus making his fortune. The same incident occurs in Dekker's Shoemaker's Holiday. Participation in fresh ventures was made easier by the development of joint-stock types of undertaking. A regular competition for capital grew up amongst the promoters of new enterprises; the "projectors" for any scheme always strove hard to convince both king and public that theirs was the better investment of any which offered. This is an example of the publicity talk of the promoter of a scheme in James I's reign, who wished to divert the flow of colonial investment into the fishing industry:

My meaning is not, to leave our fruitfull Soyle vntilled, our Seas unfrequented, our Islande vnpeopled, to seeke remote and strange countries un-inhabited, or unciuill Indians vntamed: where nothing vpon our first arriuall appears vnto vs, but earth, wood and water; for all other hopes must depend vpon our labours, vpon costlie expenses, \& vpon ye honestie of vndertakers; and for all those, at the last, the product is nothing but only Tobacco, a newe invented needeles weede; as by the vse and custome thereof made appeares. ${ }^{\mathrm{I}}$

The floating of projects became a craze. The projectors all touted in support of their flotations in this manner; painting their own schemes with glowing colours, decrying their rivals, and, if this was insufficient, following the Belgian example of raising funds by a lottery. ${ }^{2}$ It was not long before the speculative wave became pathological. The bucket-shop type of speculation was too much in evidence.

"The Lady Cope lives close at her little house in Drury Lane," wrote Sir Dudley Carlton, "and yet she is found out and much visited by cozeners and projectors, that would fain be fingering her

I University Library, Cambridge, MS. Gg. v. I8 (5): “A Discourse of the Hollanders Trade of Fishinge", folio 196.

2 T. Birch, Court and Times of James I, I, p. 60: "There is a lottery in hand, for furthering the Virginia voyage, and an under company erecting for the trade of the Bermudas". 
money upon large offers. I found there the other day, that I went to her about your money, Sir Richard Gurgrave, Sir Harry Windham; another time Taverner, and one or two such cheaters, that will quickly strip her of her money if she will not take the better heed."x

Ben Jonson admirably satirised the wiles of this type of projector ${ }^{2}$-but some idea of the suspicions which their extravagances finally aroused may be gathered from the projectors themselves. A "project" came to be synonymous with procuring some legal monopoly from the crown, uncier cover of which the projectors made their fortunes. So the author of a scheme for reorganising the fishing industry which made no such endeavour loudly advertised the difference:

Lett not the fowle name of Proiect make you preiudicate in your opinions, your thoughts, for what I propound is vnworthie, and daigneth that title: there is noe burthen, that the sharpnesse of lewde Brains can invent to vexe the common-wealth withall, but they stile it by the name of Proiect, pretending a faire face vnder a foule vizard. But the difference betweene vs, is in this kinde; I neither exact nor expect Gaine; I create noe new devises taxe or toales; I invent noe Impositions, nor raise contributions; I inforce noe man to vndertake; nor compell people to aduenture. ${ }^{3}$

So great a nuisance did the fraudulent projector become, that King James, who was himself very receptive to projects and "plotts", used the word "projector" as a general term of abuse along with."viper" and "pest" in a speech to Parliament in I609.4 Many of the projects were fraudulent or piratical-all

I Birch, op. cit. I, p. 368.

2 See, for instance, The Staple of News, and The Devil is an Ass. According to Unwin (Studies in Economic History, p. 330): "A study of the leading characters in The Devil is an Ass... would be by far the best introduction to the economic history of the period when Shakespeare had laid down his pen and was living quietly at Stratford".

3 University Library, Cambridge, MS. Gg. v. 18 (5), folio 195 back.

${ }^{4}$ Quoted in An Humble Remonstrance to his Majesty against the Tax of Ship-money (1641), p. 65. There is a mistake in the pagination, and it is printed as P. 39 . 
of them had their root in the spirit of gain. But the frequency of bogus projects was only an indication of the widespread interest in commercial affairs which had come about as a result of trade development.

The rise of all this "projecting" in England may be traced quite easily to the maritime discoveries-to the new distribution of wealth which they created by concentrating the additional purchasing power represented by fresh American silver into the hands of merchants and adventurers; to the trade with the Indies and the increased trade both in Europe and at home which the discoveries brought. ${ }^{\text {I }}$ It was an age of new fortunes. "I knew a nobleman in England", said Bacon, "that had the greatest audits of any man in my time; a great grazier, a great sheep-master, a great timber-man, a great collier, a great cornmaster, a great lead-man, and so of iron, and a number of the like points of husbandry...."2 But not all noblemen had realised that in the new golden (strictly speaking silver) age, it was necessary to be more than landlord if one was not to be outstripped in wealth. It is the self-made men who are always the chief sustainers of capitalistic advance, 3 and the fact that the new wealth was not in the hands of the landlords and the old-time moneyed men gave an opportunity for many to rise from humble beginnings to be princes of commerce or industry. Sir Bevis Bulmer, who was so active in developing mining industry in the sixteenth and early seventeenth centuries, was a self-made man whose activities became legendary. Ten years after his death Ben Jonson's audiences were expected to see the point of references to Sir Bevis Bullion:

I Adam Smith, Wealth of Nations, Iv, ch. vii, pt iii, shows how the discoveries have extended the commerce even of those European countries which may never have produced a single article consumed in America or consumed a single article produced there. Cf. ibid. Iv, ch. i.

${ }^{2}$ Francis Bacon (Lord Verulam), Essay Of Riches.

3 Professor Pirenne has more than anyone brought out the importance of the nouveauxix riches. See especially his Périodes de l'histoire sociale du capitalisme. Cf. L. Febvre, "Les Nouveaux Riches et l'Histoire", in La Revue des Cours et Conférences, June 15th, 1922. 
Pennyboy junior. Dost thou want any money, founder?

Pennyboy Canter. Who, sir, I?

Did I not tell you I was bred in the mines,

Under Sir Bevis Bullion?

Pennyboy junior. That is true,

I quite forgot, you mine-men want no money,

Your streets are paved with't: there the molten silver

Runs out like cream on cakes of gold.

Pennyboy Canter. And rubies

Do grow like strawberries. ${ }^{\mathrm{T}}$

Bulmer's career is sufficiently striking, and sufficiently typical of the age in which he lived, to call for further comment. ${ }^{2}$ Nothing is known of Bevis Bulmer's birth or parentage, save that he seems to have belonged to a well-known North-country family of the name more or less as a poor relation. As Jonson's reference suggests, he was known chiefly as a mining entrepreneur. This fact is itself not without significance. Although the fifteenth century had seen a great advance in mining operations in Europe, there is no doubt that the Spaniards' discoveries in Mexico and Peru stimulated mining in Europe still further in the next century. In almost every country attempts were made to find an America at home. Why should all the Eldorados be in the New World? Though Bulmer did not scorn to work the baser metals, or even indulge in quite other enterprises, it was the precious metals or precious stones which most fired his ambitions. We meet him first in 1566 engaged in mining in Scotland. We last hear of him in 1615 , when he died while attempting to develop the silver-lead mines of Alston in Cumberland. In between these dates he mined lead in the Leadhills district of Lanarkshire and in the Mendips, gold also in Lanarkshire, silver at Combemartin in Devon, at Hilderstone in West Lothian, at Clonmynes in Waterford and at Slaidburn in Yorkshire. He mined tin, copper, iron and coal, and had

I Ben Jonson, The Staple of News, Act I, Sc. i.

${ }^{2}$ Cf. H. M. Robertson, loc. cit. 
salt-works as well as coal-mines in Wales. He quarried marble and alabaster, and successfully sought even amethysts and pearls. His prospecting operations carried him into the Highlands of Scotland. Nor were his operations conducted on any small scale. His chief Lanark mine comprised at least sixteen shafts, with a considerable equipment. At Hilderstone he employed fifty-six men in mining operations, and there were more working at the stamp-mill over which he did not exercise control. His Rowpits mine in the Mendips was worked as a large-scale enterprise, and much capital was sunk in attempts at drainage. Moreover, these three enterprises were evidently carried on simultaneously, for about the time he began operations at Hilderstone he was experiencing trouble with untrustworthy subordinates in the Mendips and with Border reivers in the Leadhills. The mechanical technique which he developed for use in the mines he also tried to apply to other uses, so that we find him setting up a water-works near Blackfriars Bridge, consisting of four pumps worked by horses, cisterns and conduit pipes, to supply London houses with Thames water, while he received a patent of monopoly of an invention for cutting iron rods by means of water-power. Nor did Bulmer's activities, and more particularly his ambitions, stop here. In conjunction with the President of the Court of Admiralty, he had elaborated a scheme for providing the English coasts with lighthouses in return for a toll on shipping entering or clearing English ports. Within a few months he farmed the right to levy a tax on sea-borne coal leaving Newcastle from the crown for $£ 6200$ and offered to farm the impost on sweet wines for $£ \mathrm{I} 4,000$ and the right of pre-emption of all tin produced in the Stannaries of Devon and Cornwall for $£$ ro,ooo. This latter offer meant further that he was prepared to lend the tinners $£$, 0,000 as advance wages and was prepared to finance the marketing of an annual production which he valued in the neighbourhood of $£ 26,000$ ! Bevis Bulmer was a self-made man who can hardly be left out of account in the history of capitalism and the capitalist spirit. Yet there is 
nothing to suggest that his career was the result of any religious movement. He was the product of an age of opportunity.

England was the particular home of the nouveaux riches. Political conditions were more favourable, affording greater security than was to be found in many other countries. The Queen-Mother of France would not scruple to send a parvenu son of a shoemaker to the gallows, because she was offended by his ostentation; I but the self-made man was safe from this possibility in England, and knew it. He expanded his profits, whether legitimately or not was a small matter; and the illegitimate methods varied from the piracy, which was so ruthlessly carried on as to make Mendoza, the Spanish ambassador, remark that "Profit to them was like nutriment to savage beasts", to monopolising and bogus company promoting. When one has brought into light the circumstances which were favourable to the emergence of large numbers of nouveaux. riches in the sixteenth century, one has largely explained the causes of the rise of the spirit of capitalism or economic individualism. It was partly derived from the nouveaux riches themselves, ${ }^{2}$ and partly from the action of the changing economic and social environment (which provided the troubled waters in which the nouveaux riches fished) on the other classes. Medieval trade ethics were supposed to be based on the "just price". It would have been difficult to employ a similar basis in the age after the discoveries.

Unfortunately it is very difficult to try to evaluate the effects of the discoveries on industry in any convincing way. We know that they were responsible for widening the market, and therefore for increasing the scope of capitalistic production. We know that some part of the new supplies of liquid capital

A. Liautey, op. cit. pp. 85-6.

${ }^{2}$ H. Pirenne, Anciennes démocraties des Pays-Bas, pp. 252-3: "Les 'nouveaux riches' de la Renaissance sont en somme des aventuriers. Ils n'ont pas d'ancêtres, pas de traditions de famille, et l'individualisme économique se manifeste chez eux avec la vigueur propre à toutes les forces qu'a affranchies l'ardente époque à laquelle ils appartiennent". 
formed industrial investments. We know that investment in one branch of industry often called for further investment in allied branches of industry. I We know that London capital was everywhere being used to control industrial organisation in the sixteenth and seventeenth centuries, breaking down old gild regulations and restrictions. ${ }^{2}$ But no estimates have been made of the amount of investment in industry, nor are there any means of forming an estimate. The careers of individuals like Bulmer must form a clue. Nevertheless, the effects on industrial development must have been great, and the greater opportunities to be had in the industrial sphere must have tended to promote a greater seriousness and application than was apparent before the discoveries enlarged the horizon of opportunity.

The discoveries, also, and the consequent trade expansion, were responsible, first, for the great interest taken in usury questions during the sixteenth century, manifested in popular literature as well as theological treatises; and secondly, for the decision of the questions on the lines of sound common sense. The discoveries were largely responsible for the rise of the great German Gesellschaften of the Renaissance. They had not caused the first formation of these businesses; but they had caused their steady expansion and their removal to Antwerp to participate in the Eastern trade. These great firms used very often to secure capital from all and sundry as deposits; and thus they made the taking of interest general in Germany and the Low Countries. This explains the connexion between Luther's attacks on usury and on Fukkerei. The English joint-stock companies were, it seems, usually content to raise capital merely from their subscribers, although the foreign trading companies sometimes made use of loans on bottomry to finance

I Scott, op. cit. I, p. 44: "Thus the direct effect of the accumulation of capital was important; but there was the indirect one, which was probably greater, in the subsidiary trades, which grew up as a result of the new developments in industry...".

2 G. Unwin, Industrial Organization in the 16 th and 17 th Centuries. 
their shipments. But long credits were frequently given in trade, ${ }^{\mathbf{1}}$ and in many industries the extension of the part played by middle-men had led to a complex organisation in which the merchant provided the capital and assumed the risks attached to the sale of the commodity at all stages of production. Capital was being mobilised for commerce as never before in England, and this increased the necessity for credit operations, and started the development of a real money-market. ${ }^{2}$ A somewhat superficial observer of currency questions had already noticed the rise of the capital market when he wrote to Elizabeth in 1594 that "Since the Statute against vsurie did tolerate ten Vpon the hundred euerie man hath found such a sweetenes in that Vsuriall gaine that smalle store of money is hoorded vp..."3 In I6I2, Fenton, a clerical opponent of usury, complained that all borrowing was for commercial ends, attacking "the couetous desire and pride of borrowers who out of an insatiable appetite to compasse great matters, doe take vp

I W. E. Lingelbach, The Merchant Adventurers of England, p. xix: "Members were forbidden to give credit on sales for a longer period than six months, or to offer more than 7 per cent. discount for cash payments". They had evidently been forced into the Antwerp habit of giving credit for at least two fair periods; and the order suggests that 6 months credit was usual amongst the Merchant Adventurers, with a tendency to exceed this term. There is a curious (and unsympathetic) account of the management of credit by exporters in The Observations on Commerce with the Hollander: "The Merchant Adventurers by over-trading upon Credit, or with Money taken up upon exchange, whereby they lose ten or twelve, and sometimes fifteen or sixteen per cent. are enforced to make sale of their cloths at under rates.... The Merchants of Ipswich...do for the most part buy their fine Cloths upon Time; and by reason they go so much upon Credit, they are enforced (not being able to stand upon their Markets) to sell, giving fifteen or eighteen Months Day of Payment...they then presently sell their Bills...allowing after the rate of fourteen or fifteen, and sometimes twenty per cent....". (Ralegh's Works, ed. Birch, II, p. 126. I have generally quoted works ascribed to Ralegh from the $166 \mathrm{r}$ edition of his Remaines. This is not at the moment available.)

2 Tawney, Introduction to Wilson's Discourse on Usury.

3 Brit. Mus. Cott. MSS., Otho, E x, pencil folio 65 back. Entitled "The explanations of Wrighton". 
great summes of money, for money; that no money is to bee spared for such as bee true borrowers indeede". I

Similarly, Gerard Malynes, a merchant who was opposed to usury in the belief that it stimulated too much purely financial speculation, believed that " as the case for the present standeth with England and forreign Nations, we haue Vsurie like a Wolfe by the eares, dangerous to be kept, and more dangerous to abandone the same". ${ }^{2}$ And as he pointed out in his generally perspicacious analysis of currency questions:

The second propertie of money, proceeding from the operation of vsurie deuised thereupon, (whereby the measure is ingrossed and also falsified) is, That the rate of Vsurie is become the measure whereby all men trade, purchase, build, plant, or any other waies bargaine, and consequently all things depending vpon the premisses, are ruled and gouerned accordingly....3

This statement of Malynes makes it clear that in England by the beginning of the seventeenth century the practice of claiming as a right the power to receive profit from one's property, whatever form it took, had at any rate been accepted as inevitable. The recognition of the general right to take payment for a loan is the final recognition of the complete claims of private property; it marks the disappearance of one of the last of the barriers to the enjoyment of one's possessions according to one's own will which survived from the Middle Ages. And we see from Malynes that the rate of interest had already taken that position of a regulator of trade which it has to-day. 4

Modern writers who have pointed out that the prohibition

I Fenton, Treatise on Usurie, III, ch. iv.

2 Malynes, Lex Mercatoria (1636 ed.), p. 221.

3 Ibid. p. 177.

4 It is not erroneous, only one-sided, to call the rate of interest a regulator of trade, for it is both index and regulator. Of course in Malynes' time it did not bear so close a relation to speculation in either of these aspects-the lack of a central money-market made interest rates less sensitive, the generally higher rate of profit diminished the responsiveness of undertaking to changes in interest rates. 
of usury designed to protect the needy borrower was not applicable to loans to capitalist entrepreneurs, who were quite capable of looking after themselves, are only repeating a truth already recognised in the sixteenth century. Calvin had recognised it in his famous letter; Bacon in 1625 had essayed a way of escape from the dilemma.

"It appears," he said, "by the balance of commodities and discommodities of usury, two things are to be reconciled: the one that the tooth of usury be grinded that it bite not too much; the other that there be left open a means to invite moneyed men to lend to the merchants, for the continuing and quickening of trade. This cannot be done except you introduce two several sorts of usury, a less and a greater; for if you reduce usury to one low rate, it will ease the common borrower, but the merchant will be to seek for money: and it is to be noted that the trade of merchandise being the most lucrative, may bear usury at a good rate: other contracts not so. To serve both intentions, the way would be briefly thus: that there be two rates of usury...."I

This unworkable scheme was not adopted-nor the erection of grandiose models of their native montes pietatis which the Italians pressed so assiduously as the solution of the dilemma. ${ }^{2}$ But the recognition of the difficulty is important; in the usury discussions we can see the process of the bourgeois coming into his own. They were his interests that triumphed over those of the craftsman and farmer. The projector might still cry out

I Bacon, Of Usury.

${ }^{2}$ For instance, the author of a plan for abolishing usury and unlawful contracts which the needy were at times forced to make (Brit. Mus. Lansdowne MSS. 101, pencil folio Io7 ff., I 597: Modo Vtilissimo et commodo per la Corona et per il populo d' extinguere' extirpare' et del tutto cacciar uia d' Inghilterra L' Vsura et gli Illicita contratti che' talhora son constrette' Le persone' bisignose' fare, con gli Vsurari) had a Fabian scheme for replacing the usurers by a monte which should lend at to per cent. for the first five years, $8 \frac{1}{3}$ per cent. for the second five years, $6 \frac{2}{3}$ per cent. for the next five years, then at 5 per cent. and finally, when the monte disposed of sufficient funds, it should lend gratis or on payment of only such interest as would cover the administration of the fund. 
against usury, as he sometimes cries out to-day against the savings facilities provided by the banks, because he thought that the prohibition of the loan at interest would increase the amount of capital available for investment in his schemes. ${ }^{I}$ The merchant also might still decry the usurer. But if he did so, it was from one of two causes: either, like Malynes, he was protesting against the vagaries of the foreign bill market, which seemed to place the merchant and indeed the industry of the country at the mercy of the exchangers, or else he was making his protest against usury a weapon for trying to secure a lower rate of interest on his loans. Like Culpeper in I621, the merchants who borrowed rather than lent, would be content to "leaue the proofes of the vnlawfulnesse of Vsurie to Diuines", and to show only that "the high rate of V sury is a great preiudice and decay" to trade: they would be content to reduce their theology to proving that "ten in the hundred is absolutely vnlawfull, howsoeuer happily a lesser rate may be otherwise". ${ }^{2}$ The struggle to all practical intent was confined within the "capitalist" class itself by the end of the sixteenth century. The needy borrower had to be content with the ineffective clamour of his sympathetic Puritan parson. Nobody else would take him into account. But the case was different in the commercial and moneyed world itself. The divergence of interest between the banking and the commercial and speculative classes over cheap money which is prominent to-day had become the sole centre of controversy. For this was a matter in which the inter-

I University Library, Cambridge, MS. Gg. v. I8(5), folio 22o back: "The excessiue practise of vsurie is the decaie of common-wealthes, repugnant to all humanitie, charitie, and natural benevolence; and to themselues, slauery, that desire to liue poore and to die riche". There can be little doubt that this disquisition results from the author's chagrin at having been unable to interest moneyed-men in capitalising his fishing project: "Two hundred Usurors with willing minds and forward purses, are able to maister this worke, but I feare the divell, whose Friendshipp is not to advise them, but to deceive them, will not allowe a gaine so well gotten...".

${ }^{2}$ Tract against $V$ surie (1621), pp. 3, 20. 
vention of the state might still be secured, as, once or twice, it was. I The necessity of credit was recognised, even though its nature was still imperfectly understood. In this way the usury question was secularised. And the secular justification of interest payments forced itself upon the Churches. The same developments would have taken place in an England which had remained Catholic. In seeing how business considerations, which became urgent in the new conditions of economic life called into being by the material development of the sixteenth century, acted as powerful solvents of one of the most tenaciously held religious dogmas, we are given a useful guide to the amount of influence which may be allowed to religion in shaping the working beliefs of our modern capitalism.

It may be held that too much space has been devoted in this chapter to considering mere speculation. This criticism is not entirely unjustified. Much of the speculation may have been inimical to the rise of modern capitalism. Though itself a form of capitalism, it did not necessarily lead to the same end as capitalism in the industrial sphere. The same criticism may be made of those forms of capitalist enterprise chiefly associated with government debts. ${ }^{2}$ But it should be remembered that speculation is itself a part of capitalism, and that even purely irrational forms which appear to be nothing more than organised gambling may carry in them the germs of the rational specula-

I Mercantilist governments attempted to stimulate industry and commerce, and believed that setting a low legal maximum would provide cheap money for trade expansion. Government intervention had commercial, not religious objects. Again, governments were heavy borrowers and hoped to save by pegging the rate of interest down. Another motive may be seen in a proclamation made in Scotland in $166_{3}$, which reduced the legal maximum from to to 8 per cent. and ordered the 2 per cent. saved to be paid to the crown for three years. (Steele, Tudor and Stuart Proclamations, No. S. 1594.)

2 The effects of state debts have been well discussed (amongst others) by R. Ehrenberg, Das Zeitalter der Fugger (Engl. trans., condensed, Capital and Finance in the Days of the Renaissance); W. Sombart, Der moderne Kapitalismus; H. Sée, Origines du Capitalisme moderne (American trans. Modern Capitalism). 
tion which is a necessary part of the capitalist system of to-day, and will be found giving way to it. ${ }^{\text {I }}$ Moreover, we must face the difficulty that no quantitative information concerning the rise of investment in industry is available. A knowledge that an age of "projecting" was in full swing provides us with some indication that industrial development would not be starved. When funds available for investment and for making new effective demands for the products of industry had been made more plentiful by the increase in commercial undertaking introduced by the discoveries, the increase in the supplies of the precious metals, and the profit inflation, it was impossible that industry should not have benefited and impossible therefore that the stricter discipline of managing capital invested in a continuous enterprise (which is bourgeois rationalism, expressing the "spirit of capitalism" as conceived by Max Weber) should not have been encouraged. The capitalism of the machine age was very definitely foreshadowed by sixteenth- and seventeenth-century developments in the typical industries of the Renaissance-printing, armaments, silk manufacture, and the like. $^{2}$

Industrial and speculative enterprise are also often very closely related through the person of the entrepreneur. It will be found very difficult to differentiate the industrialist from the merchant, financier or speculator. Such typical firms as the I A. E. Sayous, "La spéculation dans les Pays Bas" (Journal des Économistes, 1901, p. 401), gives it as his opinion that the apparently unregulated gambling in the sixteenth-century Antwerp was not unconnected with a proper desire to get rid of the risks of market fluctuations: "...Les paris, indissolublement alliés aux marchés conditionels, montraient non seulement un violent désir de gain, mais parfois aussi des traces d'un esprit de prévoyance, et ils donnèrent naissance aux marchés à primes tant à livres qu'à recevoir si ce n'est aux stallages". It must be admitted that these modern market operations cannot be said to be good instruments for securing 'cover'.

${ }^{2}$ Cf. H. Hauser, "Les origines du capitalisme moderne en France", in Les Débuts du Capitalisme; "Le capitalisme en France au xvie siècle (ii)", in La Revue des Cours et Conférences, January 30th, 1923. See also W. Sombart, Der moderne Kapitalismus. 
Fuggers, Welsers or Hoechstetters are important for their participation in the cotton or mining industries as well as for their speculations in spices or in government funds. Bevis Bulmer, as we have seen, sought profit wherever he might find it, and would be as willing to invest the proceeds of a purely financial speculation in industry, as to apply the profits of an industrial venture to speculative finance. A similar readiness to. act in widely different fields will be found in the case of most of the sixteenth-century business men of whom records have survived. Gilbert van Schoonbeke (1519-56) was one of the great industrial capitalists of sixteenth-century Antwerp. $\mathrm{He}$ was remarkable chiefly for his building work. Beginning with a small capital, he had to sell the first house he constructed before he could secure sufficient funds with which to start the second. During his short life-time he practically remodelled Antwerp, building two thousand houses, new fortifications, quays and canals. He was able to secure the abolition of gild privileges-in 1548 it was ordered that workmen not free of the gilds of masons or carpenters might be employed under his direction, and that free trade should be allowed in building materials. But his activities were not confined to building. His last great constructional work was indeed intended as an industrial enterprise - it was the erection of a chain of breweries with their own water-supply. His official biographer wrote that:

Astonishing in his activity, he joined to his real-property operations financial affairs of importance, indulged in commercial speculations, farmed taxes and official positions, created and developed industries.

Like Sir Bevis Bulmer in England, he was first and foremost a speculator, in whatever direction proved most profitable. As a contemporary said:

In his time the activities of the aforesaid Gilbert van Schoonbeke were to buy up and sell again heritable property, houses 
and rents, to farm and let out again undertakings, tolls and taxes, and the like, in which he was especially experienced. ${ }^{x}$

Thus some of those who broke down the barriers of medieval economic traditionalism, introduced a more rational business outlook, and advanced the ideal of acquisition by means of the organisation of free labour, also practised those forms of speculation which the religio-sociological school, with its insistence on the Protestant origin of the capitalist outlook, passes by as merely "Jewish pariah-capitalism". If one regards the actual practice of business men it will be seen that the two aspects are not divorced. That such a divorce should have been made is probably a demerit of the use of the sociological method, which seeks to erect "ideal types", in place of a historical method of approach which recognises diversification. One thing which a historical analysis makes plain, is that conditions favourable to the encouragement of speculation must not be left out of account in searching for the origins of the modern capitalistic spirit.

All the individualistic and capitalistic developments here discussed were the results of a social revolution and commercial and speculative expansion which might gradually have come without the maritime discoveries; but the two great discoveries, with their mutual aid in the exploitation one of the other, were undoubtedly responsible for the rapidity of their coming. The opening of the Atlantic and Indian Oceans for commerce had much the same effect for England as the reopening of the Mediterranean to Christian shipping after the

I "D'industrien van den voorscreven Gillebert van Schoonbeke waeren in sijnen tydt, gronden van erven, huysen ende renten te coopen, ende weder te vercoopen, wagen, thollen, accynsen te pachten, ende te verpachten, ende diergelyke, waerinne hij sonderlinge geexperimenteert was...". Quoted from Biographie Nationale de Belgique, s.v. Schoonbeke (xxi, cols. $845-61$ : an appreciation by Fernand Donnet). Cf. A. É. Sayous, loc. cit. pp. 394-5; J. Wegg, Antwerp, 1477-1 559, pp. 229-33. 
Crusades had for the trade of the nations on its shores. ${ }^{I}$ The commercial revolution produced in England, however, was greater; and the growth of economic individualism consequent upon it established itself still more firmly. But there was nothing peculiar about the growth of economic individualism in England in the sixteenth and seventeenth centuries, which made it different in kind from the individualism which characterised Italy between the eleventh and the fifteenth centuries. The changes in the direction of the streams of commerce made England (along with Holland) the heir of Italy and the other prosperous lands on the medieval trade routes. Helped by their political conditions, by their lack of serious religious troubles, which so set back other countries, and given the opportunities for almost unlimited expansion by the discovery of new worlds and a new monetary supply, was it any wonder that they became the heirs not only of Italy's commercial supremacy, but of Italy's knowledge of affairs, and of Italy's practical individualism?

It is rather fantastic to ascribe the growth of a spirit of economic individualism in the sixteenth and seventeenth centuries to religious causes. On the other hand, it is eminently practical to trace the real causes of this growth in factors which are concerned purely with trade and monetary conditions connected with the discoveries. These had the effect of giving to the trading and especially the foreign trading classes a position of greater importance in the state; and the trading classes were by nature individualistic and profit seeking, just as the feudal classes were conservative. Even the feudal classes themselves were compelled to look after their own interests more carefully in a period of rapidly rising prices.

Thus the spirit of individualism spread, mainly as an effect of trade developments. The rise of the spiritus capitalisticus is largely a matter of opportunity-and of competition.

x On this, see Pirenne, Les Villes du Moyen Age, ch. v. There is also interesting material in Brentano, Die Anfaenge des modernen Kapitalismus. 


\section{CONCLUSION}

It is noteworthy that the writings of the religio-sociological school on the origins of the capitalist spirit are infected with a deep hatred of capitalism. The essay on "Die Protestantische Ethik und der Geist des Kapitalismus" ushered in as heavy an attack on the capitalist position as the materialist writings of Karl Marx. This is not immediately apparent; but even a cursory second glance shows that its general tendency is to undermine the basis of a capitalist society. It attempts to show that modern capitalism is a massive and imposing superstructure on a foundation of shifting and out-of-date religious ideas, a Moloch of Calvinist selfishness. Its great pre-occupation has been to show that, as a form of social organisation, capitalism was not a natural growth, but a crass construction of the Calvinist mind, and therefore as easily assailed as that which made it in its own image. It tried to demonstrate that capitalism is no mere piece of social mechanism which should be judged only on its own merits, but a creation of evil import and unreasonable origin.

This seems to be the natural corollary of the arguments of all who accept this line of thought. Even Professor Tawney, who, in his Religion and the Rise of Capitalism, has admitted that the capitalist spirit was not the offspring of Puritanism, has yet affirmed that it "found in certain aspects of later Puritanism a tonic which braced its energies and fortified its already vigorous temper". He accepted the theory that "Puritanism had its own standards of social conduct, derived partly from the obvious interests of the commercial classes, partly from its conception of the nature of God and the destiny of man", and "became a potent force in preparing the way for the commercial civilisation which finally triumphed at the Revolution". He believed that two elements in Calvinism were responsible for this. One was the doctrine of the "calling". The other lay in the fact that though Calvin had given approval to the life of business 
enterprise whilst subjecting it to an iron discipline, the demand for discipline later dropped into the background, leaving Calvinism as a religion which demanded free play for all forms of enterprise. Mr Aldous Huxley has stated the position still more clearly:

The Reformers read their Old Testament and, trying to imitate the Jews, became those detestable Puritans to whom we owe, not merely Grundyism and Podsnappery, but also (as Weber and Tawney have shown) all that was and still is vilest, cruellest, most anti-human in the modern capitalist system.

Yet to follow this modern way of connecting capitalism with the religion founded by Calvin is to follow a mere will-o'the-wisp. Too much attention has been paid to certain aspects of Puritanism, and too little to what was happening outside the Puritan world. Bunyan's Pilgrim's Progress (which is very anticapitalistic in attitude) has been used to show the singularly anti-social nature of the Calvinist creed which is supposed to have fashioned modern capitalism:

In the description of Christian's attitude after he had realized that he was living in the City of Destruction and he had received the call to take up his pilgrimage to the celestial city, wife and children cling to him, but stopping his ears with his fingers and crying, 'life, eternal life', he staggers forth across the fields. No refinement could surpass the naive feeling of the tinker who, writing in his prison cell, earned the applause of a believing world, in expressing the emotions of the faithful Puritan, thinking only of his own salvation. It is expressed in the unctuous conversations which he holds with fellow-seekers on the way, in a manner somewhat reminiscent of Gottfried Keller's Gerechte Kammacher. Only when he himself is safe does it occur to him that it would be nice to have his family with him. ${ }^{\text {I }}$

But this fear of earthly ties, even of earthly love, was also

I Quoted from The Protestant Ethic and the Spirit of Capitalism, translated by Talcott Parsons, p. 107. The passage in the original occurs on pp. 97-8 of the Gesammelte Aufsaetze zur Religionssoziologie. 
strong amongst the Catholics and especially amongst the Jansenists. "Love of God's creatures always diminishing our love of God, deprives us of a part of our true life, which consists entirely in the love of God", said Nicole. "The soul which pauses over His creatures retards the course of the journey by which it reaches to God; and in wishing to enjoy them it deprives itself in proportion of the enjoyment of God." "God having given me a heart to love Him," said Arnauld, "He must be the sole object of our love." I As usual, Puritan opinions had their Catholic counterparts.

There were Catholic counterparts for most of the Puritan beliefs which are supposed to demonstrate capitalism's Puritan origins. The special mission of the doctrine of the "calling" in preparing the way for a commercial civilisation cannot be determined by reference only to Puritans. The significance of Baxter or Perkins, Steele or Flavell emphasising the necessity of living an ordered life and serving God by diligence in one's worldly occupation seems much less when one remembers that across the channel priests like Crasset, Croiset, Houdry, Réguis, Bourdaloue were teaching exactly the same thing. The Puritan bourgeois morality of England loses some of its significance when it is considered how similar was the Catholic peasant morality of the Continent. And the relaxation of Calvin's strict discipline of the economic appetites in English nonconformity (on which Professor Tawney lays some stress) seems to be a less important factor in establishing a connexion between Puritanism and capitalism when one takes into account the tolerance of the Jesuits.

It was only to be expected that Calvinist discipline should have become less strict. Apart from the fact that a Church's practical beliefs in any age are always to some extent unconsciously the product of other influences-the prevailing political, scientific and philosophical temper, material conditions and so on-a Church must often be prepared to make concessions to the spirit of an age if it is to retain any influence I Quoted by B. Groethuysen, op. cit. p. I5 I. 
at all. The concessions which the later Calvinism made to the commercial spirit were in large part the sacrifice of some part of the Churches' claims in order to be able to retain others. The English had shown themselves unwilling to tolerate Presbyterian discipline; if the Calvinist Churches had refused to temper their claims to control men's everyday actions they would have been rejected as tyrants and reactionaries. Calvinism was not betrayed from within. It lost the power before

I In his contention that Calvinism freely accepted the position that there were no social obligations, Professor Tawney has unfortunately allowed one big injustice to mar his treatment. He makes an ogre of Thomas Chalmers (Religion and the Rise of Capitalism, pp. 271-2). The Elizabethan Poor Law, he said, was not intended to be the sole provision for coping with economic distress. It was allowed to become so, but even that was not enough for the Calvinists. As represented by $\operatorname{Dr}$ Chalmers they demanded the abolition of any poor law, as a poor law recognised the erroneous principle that "each man, simply because he exists, holds a right on other men or on society for existence". It is inferred that they washed their hands of all responsibility.

Chalmers' reply to this would no doubt have been that he stood on "lofty vantage ground for retorting back on sentimentalism all her own execrations". Chalmers was fighting for Christianity against legality. If we admit this right, he said, how can we justify the workhouse? If it is a right, it must be freely conceded, without punishing the applicants by confinement and hard labour. His policy therefore was not to base the combat against distress on the rights of the poor but on the duties, as Christians, of the well-to-do. He would not let the well-to-do feel they had exhausted their responsibilities by paying their poor-rates; they should work with and through the Church to relieve the temporary distress which the workhouse would have turned into pauperisation, to raise those who might be in danger of losing their self respect, to care for those who were incapable of caring for themselves. He was, in fact, an upholder of the tradition of Calvin and John Knox.

It is grossly misleading to suggest that Chalmers was a friend only of those who enjoyed worldly success. His sympathy with the "workingclasses" was real, if it was occasionally expressed in a somewhat patronising manner. He attacked the vices of the poor-it is the duty of a minister to denounce vice-but he emphasised their many virtues and invariably laid the greatest blame for their vices on the lack of consideration of the rich. His works on Political Economy were all written with the aim of combating the repudiation by the economists of "the moral ingredient as of 
it lost the will to bind business within the discipline of Christian justice and Christian charity. Catholicism exhibited no greater power over its adherents.

The chief factor in the triumph of bourgeois liberalism was the factor of economic development which made the bourgeoisie important. It came into its own as a secular force. The rise of bourgeois morality in England as a substitute for religion was not the product of Puritanism. In Catholic France one found preachers complaining in the eighteenth century that a "gospel of worldly probity, in which is comprised all the duties of reason and religion" had arisen "on the ruins of the gospel of Jesus Christ"; and that the bourgeois preferred to be known as honnête homme rather than as a good Christian. The Churches in each country had been unable in the end, in spite of all their efforts, to assimilate the class of self-made men. The decline of the Churches in England as witnesses to a Christian code of social ethics was not due to a Puritan belief that "the Lorde was with Joseph, and he was a luckie felowe". It was due to the unwillingness of a rising bourgeoisie to be bound by what it considered to be antiquated rules.

vastly too ethereal a nature for their science". He did not believe that the social mechanism was one which might be scientifically explained but could not be amended in conformity with the doctrines of Christianity. (The Chalmers Memorial Lectures of Dr Harper on The Social Ideal and Chalmers' Contribution to Christian Economics treat this subject very adequately.)

If Chalmers had cared nothing for the relief of distress he would neither have worked himself nor so strenuously encouraged others to work for social betterment. He may have been visionary and impractical in his belief that Scotland could be de-pauperised and improved socially and morally by the rejection of a poor law, relying on private secret charity, the organisation of a voluntary system of relief by the parish Churches, the escape from "the charity of law to the charity of kindness". But it cannot be said that he advocated a policy of indifference and believed in the divorce of Christianity from daily life. If "rashness is a more agreeable failing than cowardice" Chalmers' rash call to the Church of Scotland deserved better treatment from Dr Tawney than it received. There was an echo of Chrysostom about it. 
Even so, there is no reason to decry too violently the new bourgeois individualism with its profane, not Puritan, origins. It was not a mere product of greed. It inculcated a belief in honour and justice, it believed firmly in justice, thought that independently of all religion there was implanted in man a love of justice, and on this it built. It did not ask for liberty for men to indulge their anti-social greed. It asked liberty for them to look after themselves in accordance with the rules which life and business both require to be respected and the observance of which was thought to be innate to man's nature; the rules of respecting contracts and of not doing to others what one would not have done to oneself. It did not ask for economic freedom because it believed that man's spirit of emulation raised an antithesis between the common and the private good, but because it disbelieved it.

It believed that man was rational enough to prefer justice to injustice, and that free competition would be more efficacious in promoting just dealing (on the assumption that, in general, men had a preference for justice whilst any who had not would find it bad policy to indulge their love of cheating) than restrictions based on the assumption that all men were rogues.

It was not from greed that the new individualism attacked the restrictions on forestalling and regrating. It was because it believed that free competition would see the market better and more cheaply supplied. It was not greed that silently broke down the restrictions on usury; it was a recognition that the usury restrictions did not work as they were intended. It was not mere greed that protested against the restrictions on foreign trade formed by the existence of the chartered companies. It was a just protest against injurious monopolies. It was a demand that regard should be had for the realities of things, not words; that sentimentalism should not be allowed to mask the grasping selfishness of the corporations which were impairing the well-being of the country they were supposed to serve. Self-interest played a part in promoting the rise of economic individualism, but not the only part-even 
when it is recognised that much apparently disinterested reasoning may be merely the rationalisation of selfish motives. The problem must not be simplified too far.

Some day the tangled antecedents of the doctrine of economic individualism may be unravelled. But they will not be unravelled by concentrating on religion, or by search for the clues in greed, selfishness and the self-centred righteousness of men who work hard in their "calling". Perhaps those who are interested in the problems of the rise of modern capitalism and economic individualism will turn more to secular channels for enlightenment. The chief school of the economists of the sixteenth and seventeenth centuries was business experience. Re-explore after them the commercial field in which they worked, and one cannot fail to pick up some indications of the growth of their philosophy. This is not the only field for research-law and literature, philosophy and politics, all sorts of considerations are relevant to the problem. But it is a most promising field, and one which has been unduly neglected. 


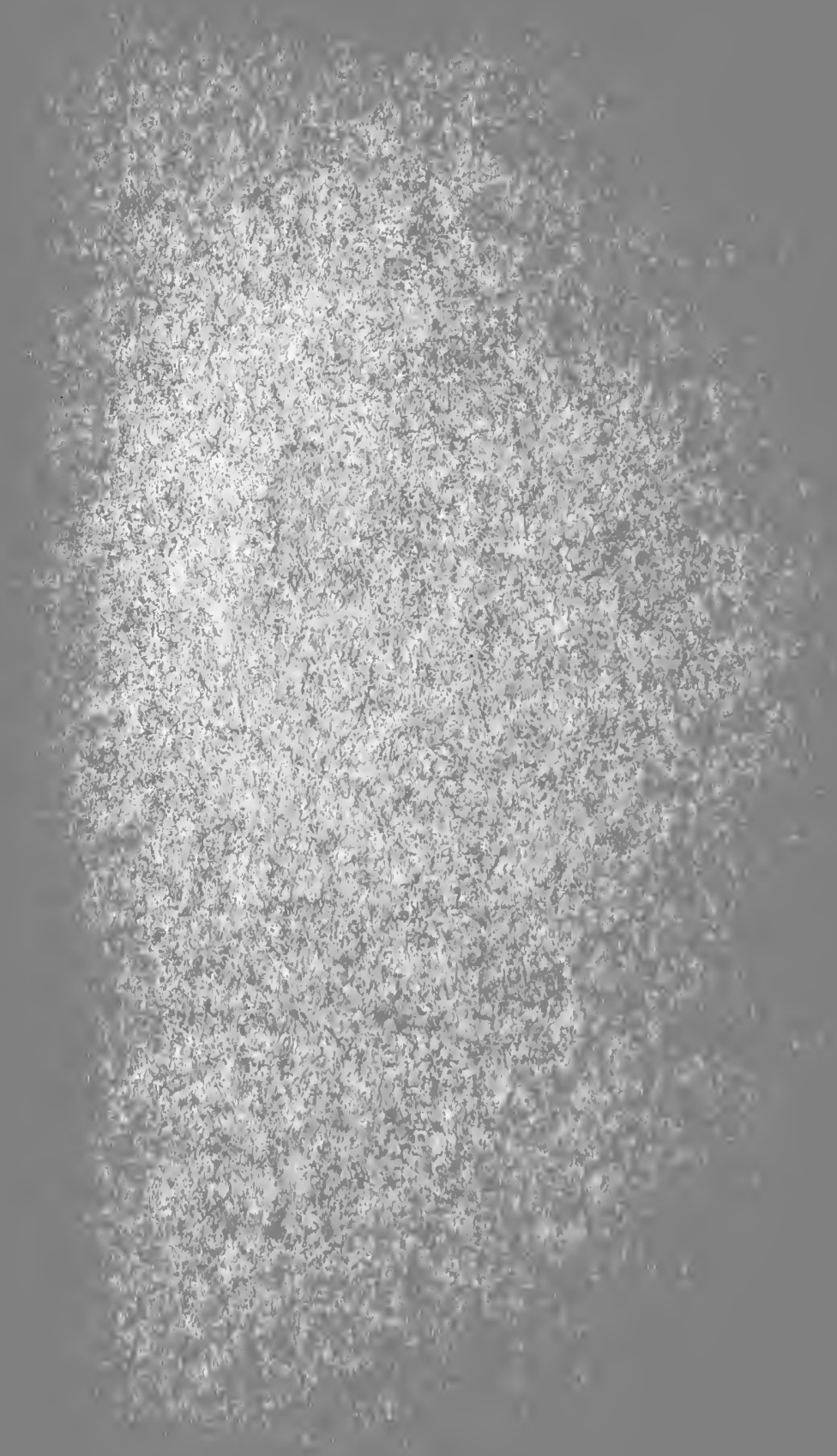




\section{N D E X}

Abbeys, as mortgage banks, 52

"A-capitalism" in South Africa, 176

Acciajuoli, firm of, 40

Accidia, 4

"Accommodating theoilogy" ascribed to Jesuits, $150 \mathrm{ff}$.

Acquisition, principle of, xii, xiv, 35$6,43-4,54-5$

Adams, Thomas, 124

African Company, profits of, 188

Alber, Father, 149

Albrecht V, Duke of Bavaria, 138

Albrecht of Brandenburg, Abp of Mainz, 112

Alcuin, xiv

Alexander VI, Pope, 192

Alston, I94

Ambition, checked by doctrine of the "calling", $6 \mathrm{ff}$.; doctrine of "calling" loses character of antidote against, I 5, 24

America, influx of Fre. ous metals from, $178 \mathrm{ff}$.

Ames, G., 130

Amsterdam, as trade centre, 169 ; cosmopolitan nature of, 170

Andrewes, Bp L., I I 3 n., $123-4$

Angelopolis, Bp of, 107-9

Antonino, St, 57, 165

Antwerp, as trade centre, I69-70, 197; borrowing in, 134-5; Marraños in, 174 ; opposition to monopoly in, $78 \mathrm{ff}$.; speculation in, 2035

Aquaviva, $147 \mathrm{n}$.

Aquinas, $\mathrm{St}$ Thomas, 6, 21, I17, 118 n., 133, 165

Aristotle, 35-6, I16, I $18 \mathrm{n}$.

Arnauld, A., 209

Asceticism, worldly, xii-xiii, r, 4-6, I6I ff.

Assimilation of capitalistic middleclasses, a task for all churches, I657

Augsburg, loans at interest in, 133-7, I $39 \mathrm{ff}$.; decline of, I 69
Avarice, suspicion of, punishable by Scots Kirk, 98

Bacon, Francis (Lord Verulam), 634, 193, 200

Banking, 47; in Venice, 80- 1 ; in Scotland, roo n.

Baptists, 5-6

Bauni, E., ro6, 156 n., 158, 159 n.

Bauny, E., see Bauni

Baxter, R., 15 ff., 165, 209; conservatism of his position, $15 \mathrm{ff}$., 20-1

Bedarfsdeckungsprinzip, 35

Bell, R., 122

beroep, $2 \mathrm{ff}$.

Beruf, 2 ff.

Biel, Gabriel, 57

Bills of Exchange, $48 \mathrm{ff}$., $198 \mathrm{n}$.

Blaxton, John, 125

Bodin, Jean, 74-5

Book-keeping, God's, $16_{3}-4$; scientific, its influence on the rise of capitalism, $52 \mathrm{ff}$.

Borgia, I37

Borrower, needy, r99-201

Bottomry, loans on, 197

Bourdaloue, Louis, 29, 209

"Bourgeois morality", 209, 2 I I-1 2

"Bourgeoisie", significance of, $165-7$

Brass industry at Dinant, $4 \mathrm{I}$

Brentano, Lujo, on Weber's philological arguments, 2 ff.; on Machiavelli, 58

"Bucket-shops", r9r ff.

Buke of Discipline, $92 \mathrm{ff}$.

Bulls, Papal, Detestabilis (1 586), 152; Cum Onus (1559), 153

Bulmer, Sir Bevis, r 93 ff., 204

Bunyan, John, 163, 208

Burghley, Lord, 189

Bushell, Thomas, 92

Business, Jesuit attitude to, $103 \mathrm{ff}$; medieval attitude to, 177; large scale, in Middle Ages, $39 \mathrm{ff}$; scale of, in Middle Ages, $37 \mathrm{ff}$; ; secularisation of, xiii, I66 n., I71 ff., 209 ff. 
Caballinus, C., 144-5

"Calling", doctrine of, xii ff., chap. I, passim, 161, 207; Catholic counterpart of, $28 \mathrm{ff}$.; changes in, $6 \mathrm{ff}$., I 5-16, 24; expressed in writings of Baxter, I5 ff.; Crowley, 7, II ff.; Latimer, Io ff.; Lever, $7 \mathrm{ff}$.; New Whole Duty of Man, 24 ; influenced by rise of capitalism, 14-15, I9, 21 ff., 32; use of philological arguments to show Protestant nature of, $1 \mathrm{ff}$.

Callixtus III, Pope, I 52, 154

Calvin, John, 123, I65; realistic attitude of, xii, I $14 \mathrm{ff}$.; self-estimate of, 102-3; views on productivity of capital, I16, I18; views on usury, $115-20, \times 29-30,145,159$, 200

Calvinism, character of Dutch, viii, 17I-3; discipline of, chap. IV, I 60 ff., $207-8,209$ ff.; distinct from Judaism, 94-5, 103, II 5 ; inimical to individualism, $\mathrm{xO}_{2}-3$; in Southern Netherlands, $173 \mathrm{ff}$.

Calvinists, lack of capitalism amongst, in South Africa, 176

Canisius, Father, 145

Canon law, 129

Cape of Good Hope, importance of discovery of, $176 \mathrm{ff}$., $185 \mathrm{ff}$.

Capital, abundance of, for investment in England at end of sixteenth century, $188 \mathrm{ff}$; Calvin's views on productivity of, I16, I1 8; Catholic views on productivity of, 118 , 159; increased mobility of, 190 ff., 197; liquid, increased by American silver discoveries, $178 \mathrm{ff}$; methods of raising, by German companies, 197; required to finance export trade, $40 \mathrm{ff}$.

Capital market, 198

Capitalism, before the Reformation, chap. II; bias against, in writers of the sociological school, $207 \mathrm{ff}$; defined by Sombart, 35; Jesuit attitude to, $103 \mathrm{ff}$.; "pariah", xv, 205 ; romantic tendencies in, $44 \mathrm{ff}$.; should be judged on its own merits, not on its alleged Calvinist origin, 207 ff.; spirit of, see below
Capitalism, spirit of; Weber's conception of, xii ff., I ff., 35,16 Iff., 172, 203; Sombart's conception of, $35 \mathrm{ff}$.; book-keeping as an influence on, $52 \mathrm{ff}$; its rise conditioned by economic developments, $36-7$, 176 ff., 206

Capitalists, assumption of risks by, 198

Carlton, Sir D., I9I-2

Castro, Paul de, I33

Catholic Church, advocates "worldly asceticism", $16_{2} \mathrm{ff}$;; attempts to find a place for the bourgeoisie, $165 \mathrm{ff}$.; develops tolerance of payment for loans, chap. vI; has a counterpart to the doctrine of the "calling", $28 \mathrm{ff}$; r relaxes ecclesiastical discipline, 103 ff.; wishes to isolate the individual through the love of God, 208-9

Catholics, in a majority in Holland (c. I609), I7I

Cervantes, $3 \mathrm{n}$.

Chalmers, Dr Thomas, misconception of his attitude towards social obligations, $210 \mathrm{n}$.

Chancellor, R., 187

Charles V, Emperor, 6I, I 54

Cheap money, 20I

Chevalier, M., 179

Chios, 45

Churches, meet common problem of an independent "spirit of capitalism", 165-7

Cistercians, and wool trade, 52

"Class war", 183

Clonmynes, 194

Cloth industry, in England, $182 \mathrm{ff}$; in Flanders, 4I-2; in Florence, 43

"Clothierism", 183

Christians, early, social standing of, $175 \mathrm{n}$.

Coal, tax on sea-borne, 195

Coinage, debasement of, in England, I $80 \mathrm{ff}$.

Combemartin, 194

Commercial activities of Catholics and Protestants compared, $168 \mathrm{ff}$.

Commercial ethics of Catholics and Protestants compared, chaps. Iv, v, vi 
Commercial regulations, $6 \mathrm{I} \mathrm{ff}$.

Company promoting, bogus, 196; see also "Projecting"

Competition, forms best way of providing for the market, $70 \mathrm{ff}$., 212 ; a sanction in favour of business honesty, 212

"Constructional" method in sociology, xi, 205

Contarini, T., 80-I

Contractus Germanicus, $135 \mathrm{ff}$.

Contractus trinus, 135 ff., I 50-I

Cornwall, r95

Cost of transport of specie in 1585 , 48

Crasset, 28, I62, 209

Credit, trade, 198

Croiset, 162-3, 209

Crowley, R., 7, in ff.

Crusades, 44-5, $205-6$

Culpeper, Sir T., 201

Cumberland, 194

Cunningham, Archdeacon W., 88 ff., III $\mathrm{n}$.

\section{Damnum Emergens, I18, 133,142 n.,} 149

Daniel, le Père, 157

Debasement of coinage in England, $180 \mathrm{ff}$.

de Boulogne, $3 \mathbf{r}$

Debts, public, 47-8, I81 n., I83, 202

Deflation, 184

Defoe, Daniel, xiii n., 26-7

Deposits of money at interest, with trading firms a means of their securing business capital, I33-4, 197

Deuteronomy, Book of, 120

deutscher Vertrag, $135 \mathrm{ff}$.

Devon, 195

D'Ewes, Sir Simonds, 122

Dinant, $4 \mathrm{I}$

Discipline, monastic, 4-5; see also Ecclesiastical discipline

Discoveries, maritime, a chief cause of the spread of the capitalist spirit, chap. vIr; their effect on industry, I $96 \mathrm{ff}$; effects on the relative economic position of different countries, $168 \mathrm{ff}$.
Dissenters, 168, 175

Distributive justice, 6

Division of labour, 24

Drake, Francis, 185 n., 188

Duhr, Father B., I 36, 148-9, $165 \mathrm{n}$.

du Moulin, 83, 159

Dyke, J., 124

Earthly ties fear of, $208 \mathrm{ff}$.

East, extent of trade with, $185 \mathrm{ff}$.

East India Company, capital of, 188; profits of, 188

Ecclesiastical discipline, in Scotland, $95 \mathrm{ff}$; in Geneva, $100 \mathrm{ff}$; amongst the Jesuits, ro 3 ff., 136 ff.; maintenance of, impossible, 209-10

Eck, Dr J., I 29, I 35 ff.

"Economic determinism", 15

Economic individualism, see Individualism

Economic rationalism, xii, 35-6, 44, 47 ff., 5 I, 202-3, 205; affected by the rise of book-keeping, $52 \mathrm{ff}$.

Economic thought, character of, in the sixteenth to eighteenth centuries, 85-6

Egolph, Bp of Augsburg, 139

Ehrenberg, R., 37

Eindhoven, 17I

Eisenreich, Father Otto, 146-7

Elderen, Father, 137

Enclosures, 8-9, 13-14, 18-19, 63, $65-6,182$

England, Church of, 175; debasement of coinage in, $180 \mathrm{ff}$; economic relations upset in, by rise of prices, 18 I ff.; export of wool from (1273), 40; recoinage of $1560-1$ in, $184-5$; usury laws in, I20-3, I98

Entrepreneur, may combine industrial and speculative enterprise, $203 \mathrm{ff}$.

Entrepreneur class, rise of, $176 \mathrm{ff}$.

Enterprise, freedom of, see Freedom

Erasmus, I62

Erwerbsprinzip, see Acquisition, principle of

Escobar, 107, 109

Evasion of positive laws, condoned by Jesuits, 106-7

Exchange, foreign, 20r; see Bills of Exchange 
Exchanger, Royal, complaints of Goldsmiths against proposed revival of, 73

Exports,-encouragement of, 65-7; of wool from England (1273), 40

"External depreciation" of English currency, $180 \mathrm{ff}$; ; provides a bounty on exports, 182

Ezekiel, Book of, I 19 n., 123

Fenton, R., 127 n., 198-9

Ferrufini, Jean-Baptiste, $77 \mathrm{ff}$.

Finance, science of, necessary to growth of capitalism, $44 \mathrm{ff}$; in Florence, $47 \mathrm{ff}$; government, 40, 47-8, 181 n., 183, 202

Flanders, cloth industry of, $4 \mathrm{I} \mathrm{ff}$.

Flavell, 209

Fleetwood, W., 123

Florence, cloth industry of, 43; finance in, $47 \mathrm{ff}$; parsimony and steady industry said to be a feature of life in, in fourteenth century, 161-2; public debt of, 40, 47-8; St Antonino and, 165; trade connexions of, 49

Formalities of contracts, Catholic insistence on, $114,115,129,150-1$, $156 \mathrm{ff}$., 160

France, Mediterranean trade of, 187 ; objection to monopoly in, 80

Franklin, B., 5, 27, 31 n., 16 I ff.

Freedom of enterprise, necessity of, for realising individualists' ideal of social progress, 34; growth of, within the shell of mercantilism, $64 \mathrm{ff}$.

Friars, 4

Frobisher, M., I87, 188

Fuggers, xii, 1 $12-13,143,170,204$

"Fukkerei", Luther's attacks on, 113 , 197

Gaetani, Cardinal, 133

Gambling, connected with rational speculation, 52 n., 202-3

Geneva, economic effects of church discipline at, roo ff.

Geographical considerations, influence of, $168 \mathrm{ff}$.

Gerhard, Johann, 113 n., 129-30, 165
Germany, usury question in, $133 \mathrm{ff}$; sale of indulgences in, $112-13$

Gesellschaften, 197

Ghent, 42 n., 6I

Gild regulations, breakdown of, 61, 197

Godric, St, of Finchale, $46-7$

"God's book-keeping", 163-4

Gold, see Precious metals

Goldsmiths, protest against revival of Royal Exchanger's office, 73

Government debts, see Debts, public; interference with trade, $G \mathrm{Iff}$., doubts as to wisdom of, $68 \mathrm{ff}$.

Gower, J, I $\mathrm{n}$.

Gregory XIII, Pope, 144, 148

Groethuysen, B., I $66 \mathrm{n}$.

Gromelgayner, xiii, xiv, 68-9

Grotius, 60

Hakluyt, 187

Hales, John, 63, 65 ff., 74

Hall, Bp, 124

Hawkins, 187, 189

Haywood, C., I 39 n., $145^{-6}$

Hemp, criticisms of bill for sowing, 70-1

Heretics, contact with, 99, 105

Heyd, 45

Hilderstone, 194-5

Hobbes, Thomas, 60-1

Hoechstetters, 134, 204

Hoffaeus, 137, i42, $146 \mathrm{ff}$.

Holland, attention to business on Sundays in, I73; attitude of Calvinists in, to money-making, viii, 173; attitude to usury in, $130-$ $\mathbf{I}$; Catholics in a majority in (c. 1609), 171; character of Calvinism in, viii, 171-3; church in, supports State monopolies, viii; Italian investments in, 170; lack of commercial honesty in, 172-3; love of theatre in, 173; luxury in, 172-3; religious indifference in, 172-3; revival of Catholicism in, $170-1$; revolt against Spain, I7I ff.; social life in, 172-3

Honesty, lack of commercial, in Holland, $172-3$; a social ideal of individualism, 212; the best policy, 22-3 
Honnête homme, 211

Houdry, 29-30, 209

Hudson, Henry, 187; Hudson's Bay 'Territory, 187

Huguenots, 168

Huxley, Aldous, 208

"Ideal types", xi, 205

Individual opinions, right to hold, under Calvinism, 102-3; under Jesuitry, 106-7, 151, 155

Individualism, builds on a belief in men's normal honesty, 212; fostered by rise of prices in the sixteenth century, I8I ff., 206; not a product of greed, 212; not antisocial, 34, 212; social ideals of, 34 , 212; significance of removal of usury restrictions for, III, 199; theoretical, may lead to a belief in necessity of State control, $59 \mathrm{ff}$.

Indulgences, sale of, I $12-13$

Industrial capitalism, in the Middle Ages, 4I ff.; combined with speculative, 203; how affected by the discoveries, $193 \mathrm{ff}$.

Industrial investment, 196-7, 203

Innocent X, Pope, 109

Inquisition, 174

Insurance, in Middle Ages, 52; agents, proposal to institute close profession of, at Antwerp, $77 \mathrm{ff}$.

Interest, justification of, a secular movement, 202; rate of, regulates business activity, 199; state regulation of rate of, 1 20-1, 201-2; see also Usury, Contractus trinus, Rent-charges

Interests, public and private: assumption of either harmony or disharmony between, equally irrational, 64; mercantilist attempts to reconcile them through strict regulation, irrational, $64 \mathrm{ff}$.

Investment, industrial, $196-7,203$; of Italians in Holland, 170; sources of, $188 \mathrm{ff}$.

Italians, invest in Holland, 170; early capitalism amongst, 36, 40-1, $43 \mathrm{ff}$.

Italy, commercial decline of, 169
Jacob, W., 179

Jansenists, 28, 109 n., 151, 159, 164, I 66 n., 208-9

Jesuits, 17, 28, 164-5, 209; allow liberty of opinion through operation of probabilism, 106-7, I5 I, 155; attitude to capitalism, 103 $\mathrm{ff}$; condone breaches of positive laws, $106 \mathrm{ff}$; engage in trade, 108-9; influence of, on usury doctrine, chap. VI; on usury legislation in Bavaria, 122, 148-9

"Jewish pariah-capitalism", xv, 205

Jews, I 15 ; see also Judaism, Marraños Jonson, Ben, 192, 193-4

Judaism, compared with Calvinism, $88,90,94-5,103,208$

Julius II, Pope, 112

Jurgens, 171

"Just price", I7, 21-2, 57, 86 n., 196

Kermis, $172-3$

Keymor, John, 66, 75

Knox, John, $92 \mathrm{ff}$.

Labour, in Scots mines, 91-2; pauper, in England, 92

Lainez, 137

Large-scale business in the Middle Ages, $39 \mathrm{ff}$.

Latimer, Hugh, 10-I I

Laud, Abp, 77

Law, Jesuits approve evasion of, $106-$ 7; canon, 129; common, significance of its survival in England, $83 \mathrm{ff}$.; Roman, significance of its reception in continental legal systems, $82 \mathrm{ff}$.

Leadhills, $194-5$

Legal institutions, and rise of economic individualism, $82 \mathrm{ff}$.

Leo X, Pope, 112

Lessius, Leonard, 105-6, 155-7, $159 \mathrm{n}$.

Levant, trade of England with, 187; export of silver through, $186 \mathrm{n}$.

Levant Company, capital of, 188; profits of, 188

Lever, Thomas, $7 \mathrm{ff}$., 89, I20-1, I65

Levy, H., 175

"Liberal mercantilism", $65 \mathrm{ff}$.

Liége, district of, $4 \mathrm{I}, 173$ 
Lighthouses, project for establishing, 195

Loans on bottomry, 197

London, as trade centre, 169

Longuet, $160 \mathrm{n}$.

Los-von-Rom movement, $175 \mathrm{n}$.

Love, earthly, condemned, 208-9

Lovelace, 122

Lucrum cessans, I18, 133, 142 n., I49, 155

Luke, Gospel according to St, 120 , 128

Luther, Martin, 141, 165; and doctrine of "calling", I ff.; and the Marraños, 174-5; as a mercantilist, I13; attacks Fukkerei, 113, 197; attacks sale of indulgences, 112

Lutheranism, 3, 97 n., 103 n., 129, 174-5

Luxury in Holland, $172-3$

Lyons, 37, 51

Machiavelli, 58-9

Machine Age, 203

Maggio, Lorenz, 138

Malines, town of, 40,49

Malynes, G., 74, 199, 201

Maona, 45

Marquard, Bp of Augsburg, 140-1

Marraños, 174

Martin V, Pope, 152, 154

Martin, Father, 138

Marx, Karl, xii, 207

Masone, Sir J., 70

Matthew, Gospel according to St, I 20

Medici, 40-1, 135

Mendips, $194-5$

Mendoza, I96

Mercantilism, $59 \mathrm{ff}$; rise of liberal, $64 \mathrm{ff}$; ; and Luther, 159

Merchant Adventurers, 63,183

Mercurian, 143 n., $145 \mathrm{n}$.

Mésenguy, 31

Middle Ages, economic development in, $33 \mathrm{ff}$; industrial capitalism in, $4 \mathrm{I} \mathrm{ff.;} \mathrm{principles} \mathrm{of} \mathrm{social}$ relations in, $33 \mathrm{ff}$.

Milton, John, xili-xiv

Mines, labour in Scots, 91-2; see also Bulmer

Mohatra contract, $156 \mathrm{n}$.

Molinaeus, C., see du Moulin
Monasticism, $4 \mathrm{ff}$.

Monetary stocks of Europe, $178 \mathrm{ff}$.

Money, quantity theory of, 179

Money-making, attitude of Dutch Calvinists to, viii, I73; of the Jesuits, $103 \mathrm{ff}$; of the Scots Kirk, $88 \mathrm{ff}$; 积 the Swiss Church, $100 \mathrm{ff}$; see also "Calling"

Money-market, development of, $198 \mathrm{ff}$.

Monopoly, Calvinist support for, viii; unfavourable to extension of capitalist enterprise, $76 \mathrm{ff}$; opposition to, at Antwerp, $78 \mathrm{ff}$., in England, $81-2$, in France, 80 , in Venice, 80-1, not confined to Puritans, $77 \mathrm{ff}$., justified by its abuses, 77, 212

Montes pietatis, 200

Mortgages, 47, 52

Nationalism, $58,112-13$

Natural law, 7, 84-5, 131-2

Netherlands, see Holland, Southern Netherlands

Newcastle, 195

New Whole Duty of Man, $21 \mathrm{ff}$.

New York, 187

Nicole, 28, 209

Nonconformists, 168,175

North America, English colonies in, 188, 191

North-East Passage, 187

North-West Passàge, 187

Norton, 123

"Nouveaux-riches", 193 ff., 196

"Office", 3

"Officio", 3

"Oficio", 3

Opposition to monopoly, see Monopoly

"Or bearer" formula, $49 \mathrm{n}$.

Parable of the Talents, 117

Paradinas, 149

"Pariah-capitalism", xv, 205

Partnerships, medieval, 37, 39-40

Pascal, Blaise, $151,156 \mathrm{n}$.

Paul, St, 4, 93

Pauper labour in England, 92

Pecunia non parit pecuniam, I 16 
Pegolotti, 49

Perkins, 209

Peruzzi, 40

Philological arguments, employed to show Protestant nature of the doctrine of the "calling", I ff.

Piracy, 44

Pirenne, Professor H., 38, 46 n., $193 \mathrm{n}$.

Pirot, 104, 106, $158 \mathrm{ff}$.

Pisano, L., 44, 52

Pius V, Pope, 152-4

Plàntations, 188, I9I

Poor relief, in Scotland, $89 \mathrm{ff} ., 210 \mathrm{n}$.

Popes: Alexander VI, II ; Callixtus III, 152, 154; Gregory XIII, 144, 148; Innocent $X$, ro9; Julius II, II2; Leo X, II2; Martin V, I52, 154; Pius V, 152-4; Sixtus V, 152

Potosi, 179

Precious metals, American, how distributed through Europe, 169 n., $179 \mathrm{ff}$; d drain of, from Europe, through Eastern trade, $185 \mathrm{ff}$; influx from America, $178 \mathrm{ff}$; stocks of, in Europe, $178 \mathrm{ff}$.

Predestination, social effects of doctrine of, $90,95 \mathrm{ff}$.

Pre-emption of tin, 75, 195

Prices, social effects of rise of, in sixteenth century, $178 \mathrm{ff}$., 206

Privateering, 188-9

Private property, see Property

Privy Council, 63, 183

Probabilism, 106-7, 138-9, 151, 155

Productivity of capital, Calvin's views on, 116, I18; Catholic views on, 118,159

Profits, as source of investment, $188 \mathrm{ff}$; of African Company, $\mathrm{I} 88$; of Drake's privateering, $185 \mathrm{n}$.; of the East India Company, 188; of the English cloth industry, $182 \mathrm{ff}$; of the Hudson's Bay Company, 197; of the Levant Company, 188; of the Russia Company, I88-9; of the slave trade, 187 ; inflation of, 183

"Projecting", and industrial investment, 203; see also "Projectors"

"Projectors", I89 ff., 200-1 ; see also Bulmer; van Schoonbeke
Property, private, necessity of, in system of economic individualism, 34

Proverbs, Book of, 20 n., 90, 94-5

Purchasing power parity, 180

Puritan, beliefs, Catholic counterparts for, $28 \mathrm{ff}$., I $62 \mathrm{ff}$., 208-9; doctrine of "calling", xii ff., chap. I, 124, 161, 207, 209; attitude to usury legislation, $120 \mathrm{ff}$.

Quakers, I75

Ralegh, Sir W., 70 ff., 75

Rate of interest, regulates business activity, 199; maximum, fixed by law, I 20-I, 20I-2

Rationalism, see Economic rationalism

Ravenna, 36

Redeeming time, 16, I9

Reformation, detracted from authority of the Church, 13I-2

Réguis, 30, I63, 209

Relief of Poor, in Scotland, 89, 92-4, 2 IO n.

"Renaissance State", influence of, on rise of capitalism, chap. III

Rent-charges, I42 n., I49, I 52 ff.

Riches, distrust of, amongst Calvinists, viii, 164

Rise of prices in the sixteenth century, I $78 \mathrm{ff}$; ; effect on labour and profits, I83; social effects of, $181 \mathrm{ff}$., 206

Risk-bearing, a central feature of capitalism, 46

Risks, assumption of, by capitalists, 198

Roman Catholics, see Catholics

Romantic tendencies in capitalism, $44 \mathrm{ff}$.

Rosephius, 140, 142-3, 144-5

Russia Company, 188

Sabbatarianism, economic effects of, $98 \mathrm{ff}$.

Sachins; Claude de, I15, I20, 130

St Gotthard, trade of, 38

St Thomas, see Aquinas

Salmasius, see Saumaise

Sanchez, 107

Sanders, N., I3I 
Sanderson, William, 64-5

Saracens, 36

Saumaise, C., 130-1, 159, 165

Savings, made out of profits, $188 \mathrm{ff}$.

Schoonbeke, G. van, 204-5

Scotland, as example of a Calvinist country, chap. IV; Church discipline of, unfavourable to economic progress, $97 \mathrm{ff}$; ; banking in, $100 \mathrm{n}$.; poor relief in, 89, 92-4, $210 \mathrm{n}$.

Scots, vices of, $88 \mathrm{ff}$.

Scotti, 40

Secularisation of business affairs, xiii, 166 n., 17 I ff., 209 ff.

Sée, Professor H., on Puritan attitude to usury, $121 \mathrm{ff}$.

Self-interest, attempt to make it coincide with public interests a feature of liberal mercantilism, $\sigma_{5} \mathrm{ff}$.

Self-made men, $193 \mathrm{ff}$., 196

Seville, trading ventures of Jesuit College at, 108 $\rightarrow$

Shakespeare, 3 n., 124

Ships, size of, in Middle Ages, 37, $4^{1}$

Silver, see Precious metals

Sixtus V, Pope, 152

Size, of medieval business transactions, $37 \mathrm{ff}$; of medieval ships, 37, $4 \mathrm{I}$

Slaidburn, 194

Smith, Adam, 54 n., 66, 100 n., 190

Social relations in the Middle Ages, principle of, $33 \mathrm{ff}$.

Sociological method, xi, 205

Sociological school, biassed against capitalism, 207-8

Soetbeer, $185-6$

Solifidianism, 15

Sombart, W., chap. II, passim, 95, 133, 161 ; defines capitalism, 35

South Africa, lack of capitalism amongst Calvinist farmers of, 176

South America, Jesuit trade in, 103

Southern Netherlands, Marraños in, I74; opposition to Spanish policy in, 174; spread of calvinism in, I 73 ff.; see also Flanders, Dinant

Spain, banking in, 48, 5I-2; export of precious metals from, 179-80; government policy in, adverse to economic development, 169 ; revolt of Holland against, $171 \mathrm{ff}$.
Speculation, 41, 46-7, 51, 105, 108-9, II I n., 189 ff., $202 \mathrm{ff}$.

Speculative industry, development of, $183 \mathrm{ff}$.

Spirit of capitalism, see Capitalism

Stannaries, pre-emption of tin in, 75, I95

State control of economic life, a consequence of one type of individualist doctrine, $59 \mathrm{ff}$.; opposition to, $64 \mathrm{ff}$.

"State merchant", 69-70

Steele, 209

Stotz, $143-5$

Sunday observance, economic effects of, in Scotland, 98-9; lack of, in Holland, 173

Talents, Parable of the, 117

Talmud, 95

Tawney, Professor R. H., 83, 207-8, 209, $210 \mathrm{n}$.

Theatre, love of, in Holland, 173

Third orders, 4-5

Ties, earthly, fear of, 208-9

Tillage, criticism of Statute of, $7 \mathrm{I}-2$

Time, "redeeming", 16, I9

Tin-mining, 194-5

Tobacco, 188, 191

Torres, Father, 149

Trade, extent of medieval, $37 \mathrm{ff}$; extent of Eastern, 185 ff.; expansion, stimulated by the discoveries, $187 \mathrm{ff}$., a main cause of the rise of a "spirit of capitalism", 36-7, 176 ff., 206

Trade credit, 198

"Traditionalism", "pagan" emancipation from, 58

Transport of specie, high cost of, 48

Tronson, Father, 162

Tulip mania, 172

Usury, Thomas Adams on, 124; Aepinus on, 128; Ames on, 130; Andrewes on, 1 I 3 n., 123-4; Bacon suggests two rates of, 200; Bauni and, 10G, $158-9$; becomes generally debated, I 97 ff.; Blaxton's testimony to Puritan attitude to, 125; Caballinus and, 144-5; Calvin's opinions on, 115-19; change of 
attitude to, in England, not due to Puritanism, $125 \mathrm{ff}$; Dyke and, 124; Gerhard and, 129-30; Gesner and, 128; Grotius and, 128; Hunnius and, $128-9$; influence of Jesuits on attitude to, chap. vr; interpretation of Scripture texts on, I1 5-1 7, 128 ; Melanchthon and, 128 ; opinions of Protestant reformers cited against, $113 \mathrm{n}$., 125; opinions of Protestant reformers cited in justification of, $113 \mathrm{n}$.; opposition to, a weapon for securing lower maximum rates of interest, 20r; Pirot and, IOG $7,158 \mathrm{ff}$; Protestant opinion and, chap. $v$; removal of restrictions on, an index of the relative importance of business considerations and religious dogma, 202; Saumaise and, 130-1; Scots Church and, 98-9; Swiss Church and, $100 \mathrm{ff}$; Z Zwingli and, 128

Usury legislation, attitude of Jesuits to, 106, 153-4; attitude of Puritans to, $120 \mathrm{ff}$; ; evaded by subterfuge, 114, 120, 122; ineffective, 212; influenced by Jesuits in Bavaria, 122; significance of relaxation of, 199

Utilitarianism, 6I

Uzzano, G., 49-5 I

Valenzia, Gregory of, 146, 148-9, 156

Value, adoption of objective or subjective theories of, shows philosophical bias, $86 \mathrm{n}$.

van der Veken, I7I

van Schoonbeke, 204-5

Veken, van der, $17 \mathbf{I}$

Venice, 144-5; appreciation of money at, 51 ; banking in, 80-1; objection to monopoly in, 80-1
Wales, 195

Water-works, set up near Blackfriars Bridge, 195

Wealth, respect due to, 24-5; distrust of, viii, 164

Weber, Max, on Bunyan, 163,208 ; on comparative economic activity of Protestants and Catholics, I68, 170; on doctrine of the "calling", I ff.; on economic rationalism, xii, 44, 203; on Franklin, 3I n., I6I ff.; on the Friars, 5 ; on "God's book-keeping", $\mathrm{I}_{3}-4$; on opposition to monopolies, 77 ; on speculation, $\mathrm{xv}, 4 \mathrm{I}$; on worldly asceticism, xii, I, 5; an opponent of capitalism, 207-8; employs a sociological approach to a historical problem, xi, xv, 15, 205; his conception of the spirit of capitalism, xii ff., 203; his use of philological arguments, $\mathbf{I}$ ff.

Welsers, 139, 204

Wheeler, Thomas, 190

Whole Duty of Man (1657), 15

Wiebe, 178 ff., 186

William, Duke of Bavaria, 122, 147 n., 148

Wilson, Dr T., xiii, xiv, 68-9, 122-3, 126

Wines, farm of impost of sweet, 195

Wood's Survey of Trade, 175

Wool exports from England in 1 273, 40

Work, doctrine of, 4

Works of the Puritan Divines, 27

"Worldly asceticism", xii-xiii, I, 4-6; a feature of medieval Florence, 161; lampooned by Erasmus, 162; recommended by Catholic priests, 162-3

"Wrighton, the explanations of", 198

Ympym, 56

Ypres, 39, $42 \mathrm{n}$. 


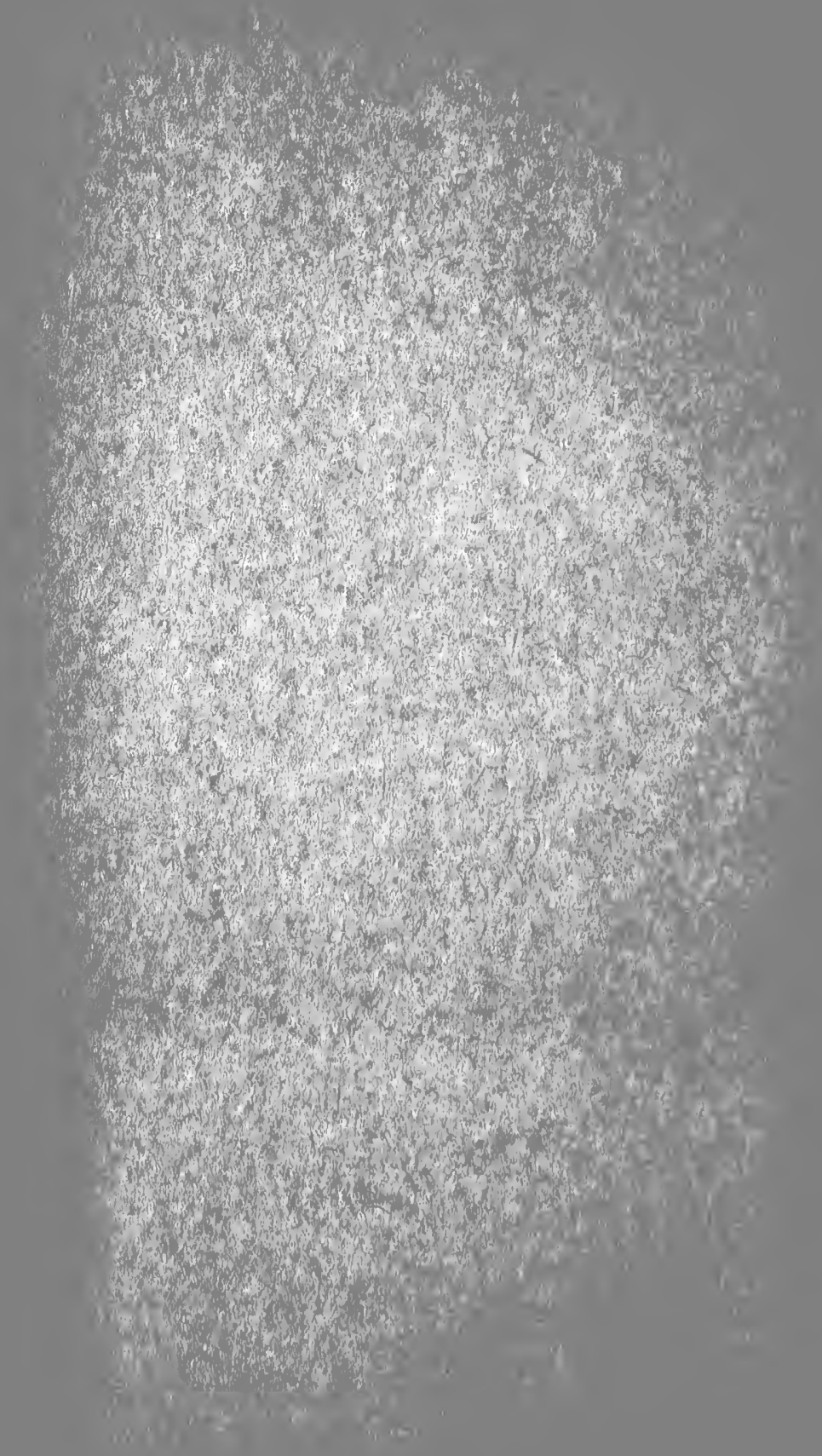




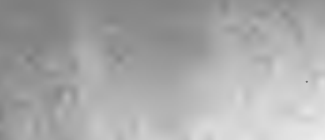




\section{Date Due}

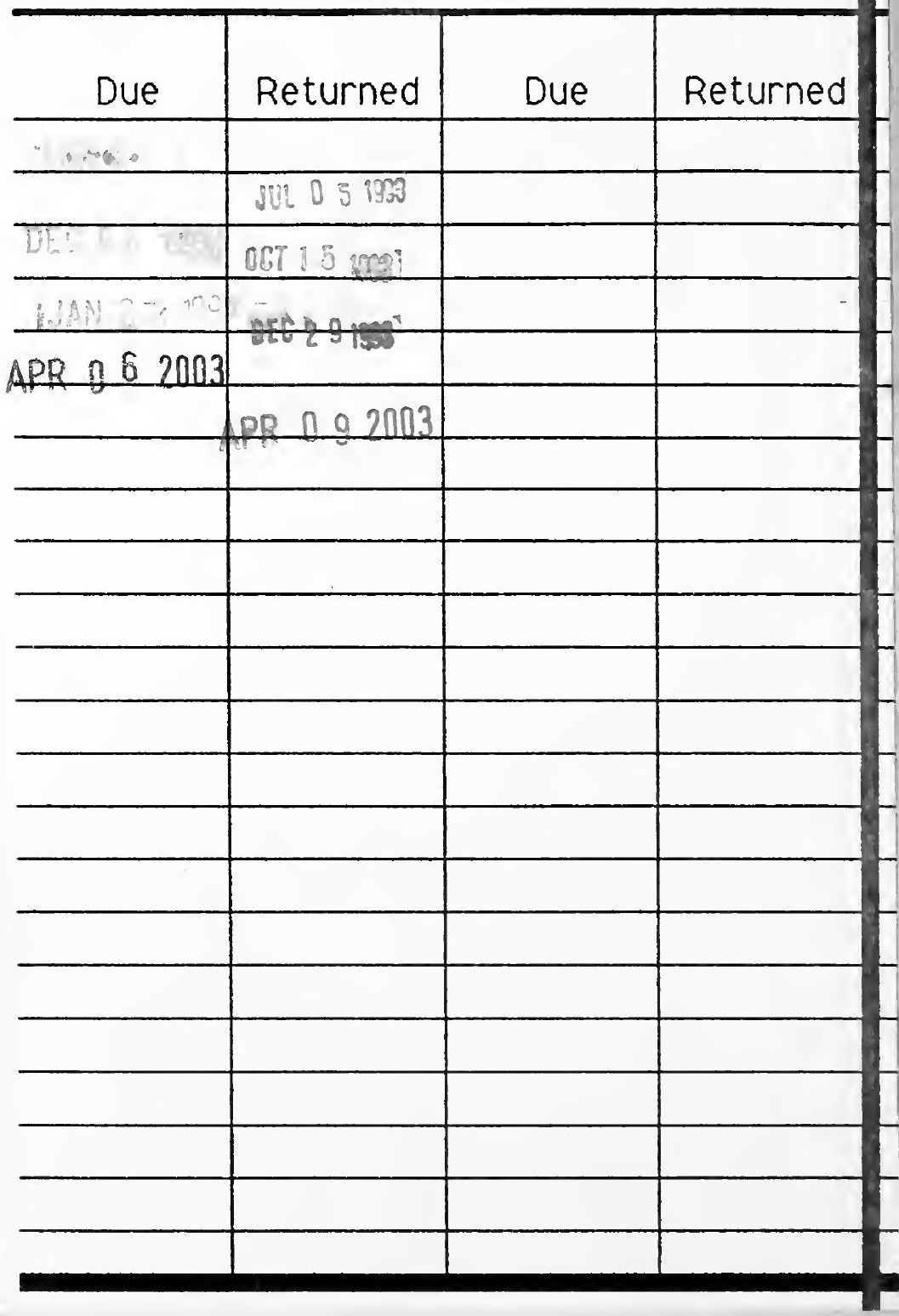




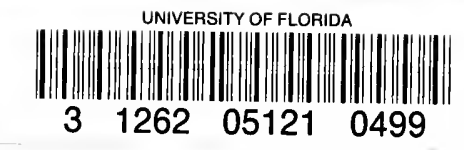

$$
\begin{aligned}
& 261 \\
& R .649 a \\
& 1.59 \\
& c .2
\end{aligned}
$$


